CARLOS DAHER PADOVEZI

\title{
CONCEITO DE EMBARCAÇÕES \\ ADAPTADAS À VIA APLICADO À \\ NAVEGAÇÃO FLUVIAL NO BRASIL
}

Tese apresentada à Escola Politécnica da Universidade de São Paulo, para obtenção do título de Doutor em

Engenharia

São Paulo 
CARLOS DAHER PADOVEZI

Engenheiro Naval, Escola Politécnica da USP, 1978

Mestre em Engenharia, Escola Politécnica da USP,1997

\section{CONCEITO DE EMBARCAÇÕES \\ ADAPTADAS À VIA APLICADO À \\ NAVEGAÇÃO FLUVIAL NO BRASIL}

Tese apresentada à Escola Politécnica da Universidade de São Paulo, para obtenção do título de Doutor em Engenharia

Orientador: Prof. Dr. HERNANI LUIZ BRINATI

Escola Politécnica da USP

São Paulo, 
Este exemplar foi revisado e alterado em relação à versão original, sob responsabilidade única do autor e com a anuência de seu orientador.

São Paulo, 31 de outubro de 2003.

Assinatura do autor

Assinatura do orientador

FICHA CATALOGRÁFICA

Padovezi, Carlos Daher

Conceito de embarcações adaptadas à via aplicado à navegação fluvial no Brasil / C.D. Padovezi. - ed. rev. - São Paulo, 2003.

215 p.

Tese (Doutorado) - Escola Politécnica da Universidade de São Paulo. Departamento de Engenharia Naval e Oceânica.

1.Comboio de embarcações (Projeto) 2.Segurança à navegação 3.Impactos ambientais I.Universidade de São Paulo. Escola Politécnica. Departamento de Engenharia Naval e Oceânica II.t. 
Dedico este trabalho a Ethel, minha esposa, e aos meus filhos Naiara, Daniel e Maíra. Incansavelmente ao meu lado, em todas as etapas de esforço, de descoberta, de cansaço e de realização;

aos meus pais, com gratidão eterna;

ao grande engenheiro naval, pesquisador incansável e saudoso amigo Kazuo Hirata. 


\section{AGRADECIMENTOS}

- Ao meu orientador Prof. Dr Hernani Luiz Brinati, por ter aceito o desafio de me orientar no pouco tempo regulamentar que me restava, tarefa que realizou de uma forma precisa, paciente e indispensável.

- Ao meu amigo Prof. Dr Mardel Bongiovanni de Conti, pelo grande estímulo para a minha retomada dos trabalhos de pós-graduação.

- A todos os meus amigos e colegas do Instituto de Pesquisas Tecnológicas do Estado de São Paulo - IPT, perseverantes e dedicadíssimos ao trabalho de pesquisas tecnológicas.

- Aos poucos, e sempre valorosos, engenheiros navais e tecnólogos fluviais que têm lutado por um futuro melhor da navegação fluvial no Brasil.

- Às empresas que autorizaram a utilização, neste trabalho, de dados obtidos em seus estudos e embarcações: Administração das Hidrovias do Tocantins e Araguaia AHITAR, Departamento Hidroviário do Estado de São Paulo - DH e Comercial Quintella.

- À Maria Ap. P. Gandara Mendes, Marcos Lanari, Luciano M. Santos, Newton N. Pereira e Marcelo P. Reginato, por auxílios no tratamento de dados experimentais. 


\section{RESUMO}

PADOVEZI, C.D. Conceito de embarcações adaptadas à via aplicado à navegação fluvial no Brasil. 2003. 215 p. Tese Doutorado - Escola Politécnica, Universidade de São Paulo, São Paulo.

É proposto um modelo de procedimentos de projetos de comboios fluviais adaptados às condições existentes das vias navegáveis, a partir de uma visão ampliada da necessidade de obtenção de menores custos de transporte, com níveis adequados de segurança e de respeito ao meio ambiente. Uma análise das inter-relações técnicas entre hidrovias e embarcações, assim como dos condicionantes e implicações do conceito de embarcações adaptadas às vias navegáveis, orientou a elaboração do modelo. Este foi estruturado em módulos, com o objetivo de reproduzir, um a um, os fatores mais importantes que influenciam a eficiência, a segurança e o nível de interferência ambiental do transporte de cargas por comboios. Um programa computacional foi desenvolvido como instrumento de aplicação do modelo, consolidando os procedimentos propostos para a escolha das melhores alternativas de projeto e de operação de comboios. Resultados experimentais com comboios em escala real e com modelos em tanques de provas, foram utilizados para validação dos procedimentos adotados. Dados de acidentes com comboios em várias hidrovias do mundo foram utilizados como bases para avaliações de risco. $\mathrm{O}$ modelo foi aplicado aos casos de transportes de soja pela hidrovia Tietê-Paraná e pelo rio Araguaia, exemplificando as formas de análise e de escolha das alternativas de soluções de projeto. Ao final, os resultados obtidos comprovaram a utilidade da adoção de um enfoque mais abrangente do processo de projeto de comboios fluviais.

Palavras-chave: hidrovias, comboios fluviais, projeto de embarcações, custos de transportes, modelo de risco, efeitos ambientais 


\begin{abstract}
PADOVEZI, C.D. Waterway adapted ships concept applied on Brazilian inland navigation. 2003. 215 p. Tese Doutorado - Escola Politécnica, Universidade de São Paulo, São Paulo.
\end{abstract}

It is proposed a procedure model for design of barges push-tow adapted to waterway actual conditions, with the purpose of minimize transportation costs but always making verifications of navigation safety and ambient interferences levels. An analysis of inter-relations on inland waterways and cargo ships and, also, detailed conditionings and implications of waterway adapted ships concept, was used for model elaboration. It was structured in blocks to reproduce, one to one, the most important factors that modify efficiency, safety and environmental interference levels of barges push-tow cargo transportation. A computational program was developed to consolidate the proposed model and to apply procedures to choose best design and operational alternatives. Results of full scale and towing tank tests with push-tows were used to verify the mathematical and semi-empirical models. Barges push-tows accidents data from waterways of the world was used as risk model basis. To evaluate its effectiveness, the model was applied to bulk grain transportation cases by TietêParaná waterway and by Araguaia river. The results shows that the special emphasis on three factors (efficiency, safety and ambient) improves the quality of barges pushtow design process.

Key-words: inland waterway, barges push-tow design, transportation costs, risk model, environmental effects 


\section{SUMÁRIO}

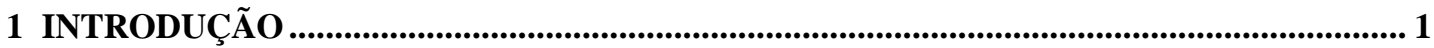

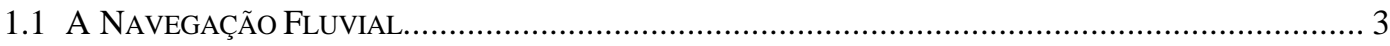

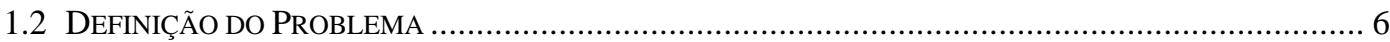

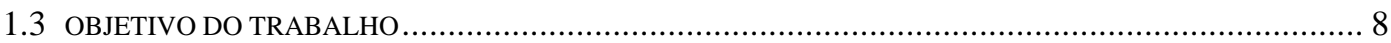

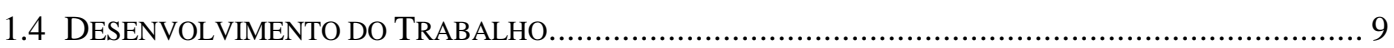

2 O SISTEMA DE TRANSPORTE POR NAVEGAÇÃO FLUVIAL ......................................... 11

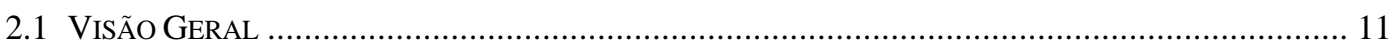

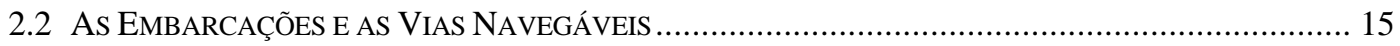

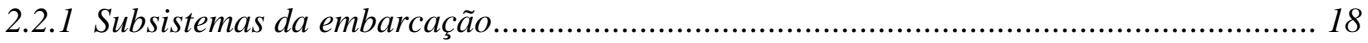

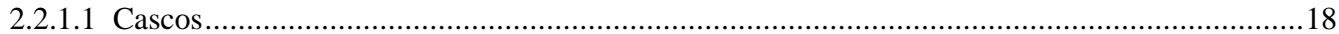

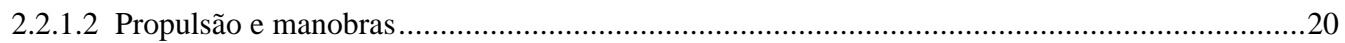

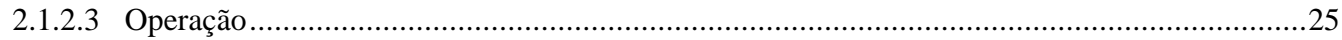

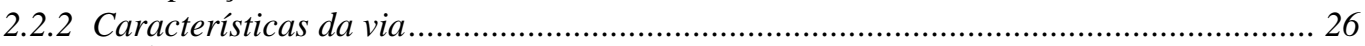

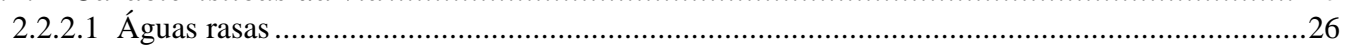

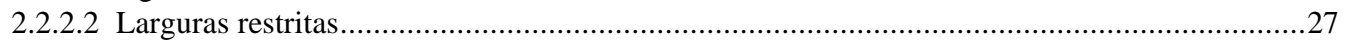

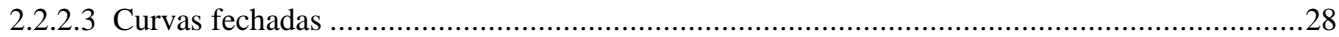

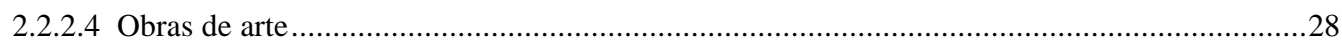

2.2.2.5 Locais com formação de ondas por ventos ...................................................................29

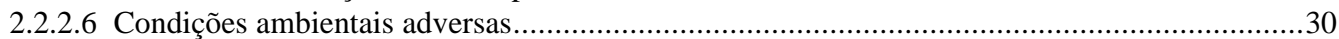

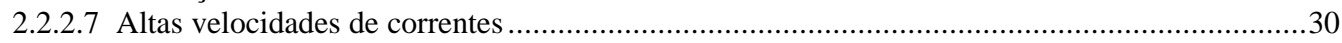

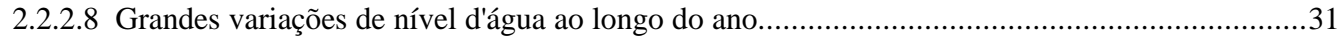

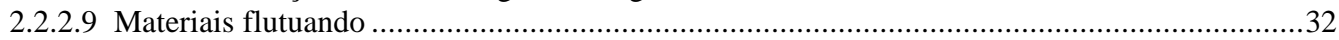

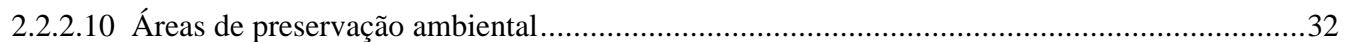

2.3 O Transporte Hidroviário e a Questão AMbIEnTAL ............................................ 33

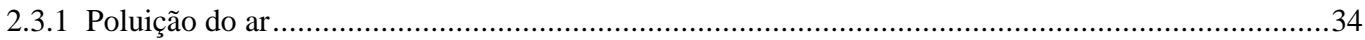

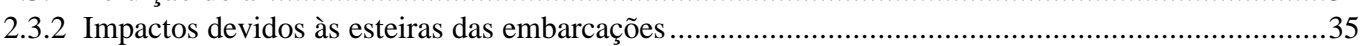

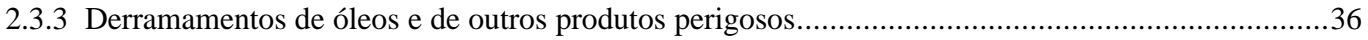

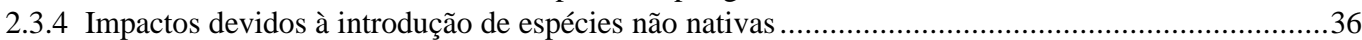

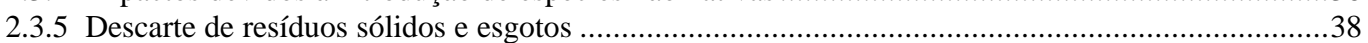

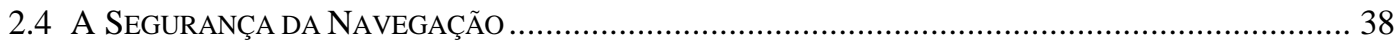

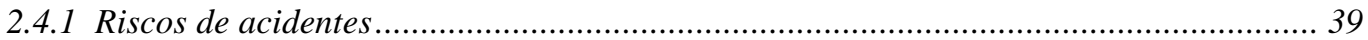

2.4.2 Aspectos de segurança de embarcações fluviais......................................................... 41

2.4.3 Um exemplo de aumento de segurança: passagens sob pontes no rio Tietê................... 43

2.5 INTEGRAÇÃO ENTRE EMBARCAÇÕES E VIA NAVEGÁVEL ................................................. 47

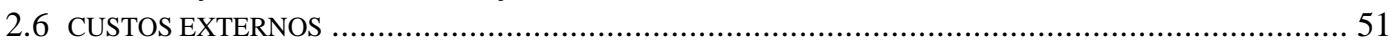

3 APLICAÇÃO DO CONCEITO DE EMBARCAÇÕES ADAPTADAS À VIA........................ 53

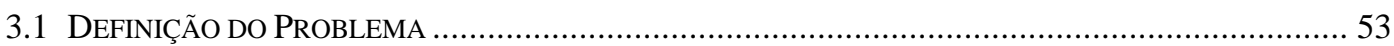

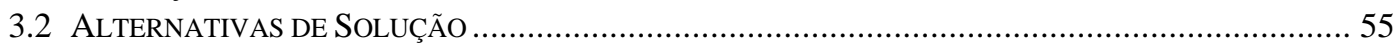

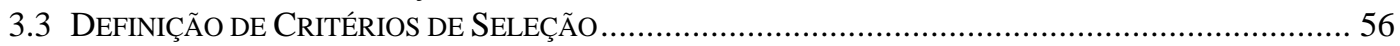

3.3.1 Avaliação da Eficiência ou Desempenho Econômico ................................................... 57

3.3.2 Avaliação da Segurança da Navegação .................................................................... 57

3.3.3 Avaliação da Interferência Ambiental Direta............................................................ 58

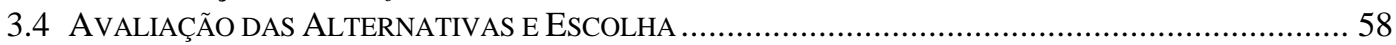

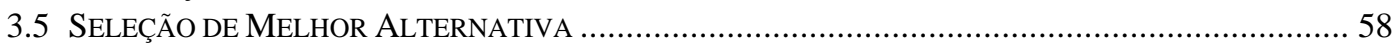

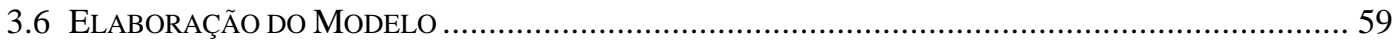

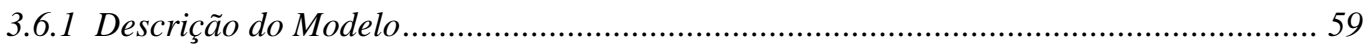

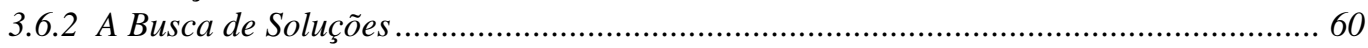

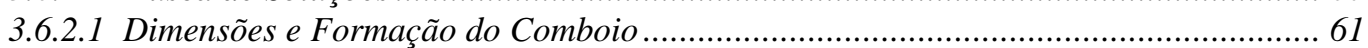

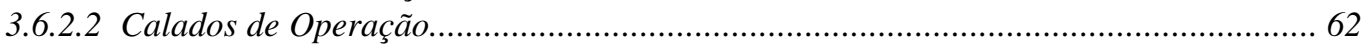


3.6.2.3 Potência Instalada no Empurrador ........................................................................ 63

3.6.2.4 Qualidade de Manobras do Comboio..................................................................... 64

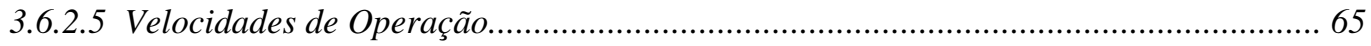

3.6.3 Resumo das Verificações das Alternativas de Projeto ...............................................6 66

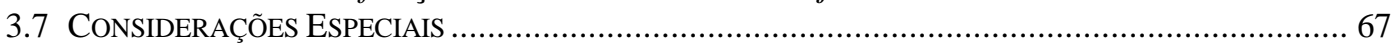

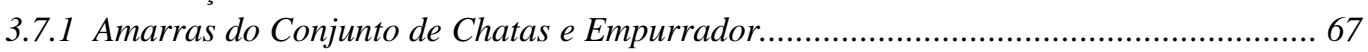

3.7.2 Volume do Tráfego.................................................................................................. 67

3.7.3 Variações de Nível D’água ao Longo do Ano............................................................. 68

4 DETALHAMENTO DO MODELO ELABORADO ....................................................... 69

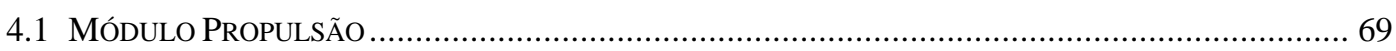

4.1.1 Estimativas de Resistências ao Avanço de Comboios Fluviais....................................... 69

4.1.2 Estimativas de Coeficientes propulsivos de Comboios Fluviais .................................... 71

4.1.3 Curvas de Água Aberta dos Hélices dos Empurradores.............................................. 72

4.1.4 Verificação de Presença de Cavitação Excessiva ......................................................... 72

4.1.5 Estimativas de Desempenho Propulsivo .............................................................. 73

4.1.6 Sistemas de Propulsão Não Convencionais ................................................................ 75

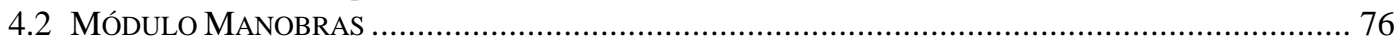

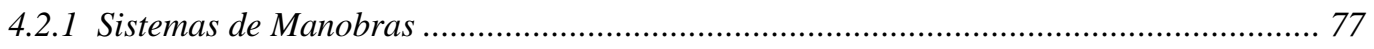

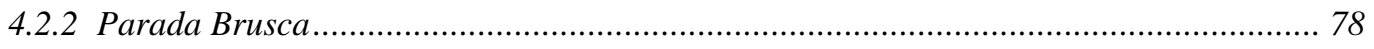

4.2.3 Manobras de Comboios com Chatas Vazias ............................................................. 81

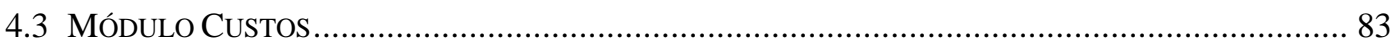

4.3.1 Formulação de Modelo de Cálculo de Custos ................................................................. 83

4.3.2 Parâmetros Descritivos do Problema ........................................................................... 84

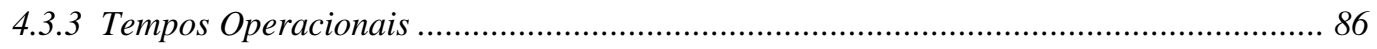

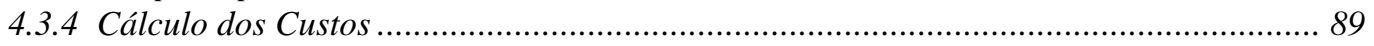

4.3.5 Custo Total e Fator de Mérito.................................................................................... 93

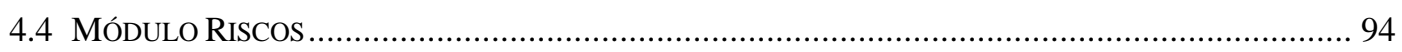

4.4.1 Definição de Riscos ............................................................................................... 94

4.4.2 Tipos de Acidentes com Comboios em Hidrovias Brasileiras ....................................... 96

4.4.3 Freqüências e Conseqüências ...................................................................................100

4.4.4 Estimativa de Probabilidade de Ocorrência de Acidentes ........................................103

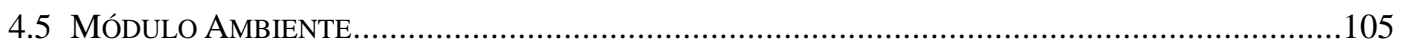

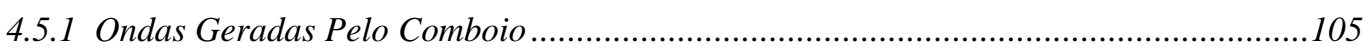

4.5.1.1 Estimativa de altura de ondas .................................................................................105

4.5.1.2 Estimativa de forças nas margens provocadas por ondas ......................................106

4.5.1.3 Critérios de avaliação da estabilidade das margens............................................106

4.5.2 Efeitos no Fundo do Rio ........................................................................................... 107

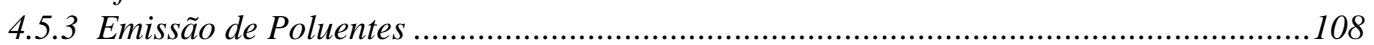

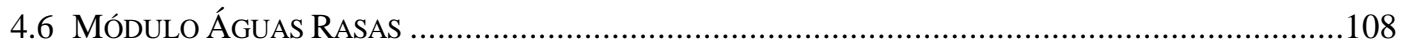

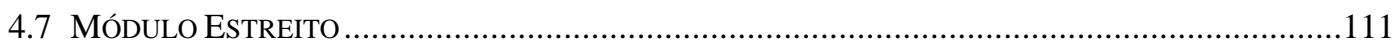

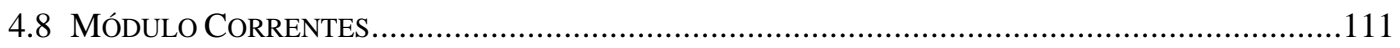

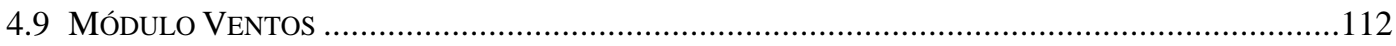

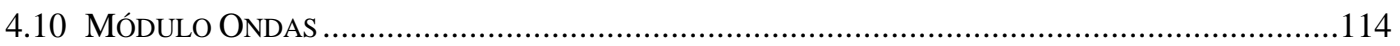

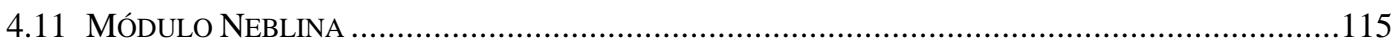

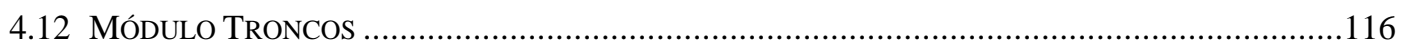

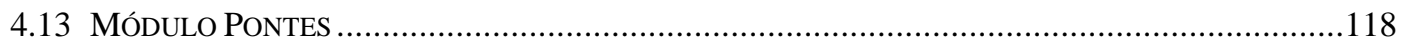

4.13.1 Verificação da Necessidade de Desmembramentos ................................................118

4.13.2 Probabilidade de Ocorrência de Acidentes em Pontes ............................................120

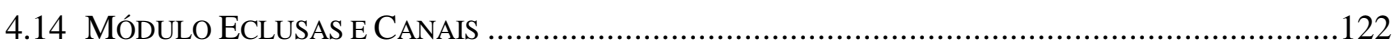

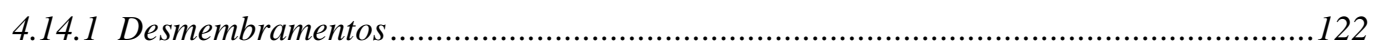

4.14.2 Tempos em Eclusas e em Canais ..............................................................................123

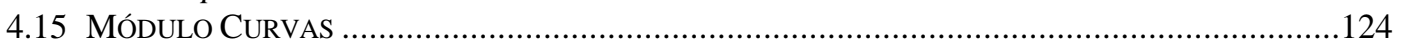

5 APLICAÇÃO DO MODELO - PROGRAMA ADAPTA ....................................................125 
5.1 DESCRIÇÃo do ProgramA........................................................................................... 125

5.2 ENCADEAMENTO DAS FUNÇÕES DO PROGRAMA ADAPTA …..............................................128

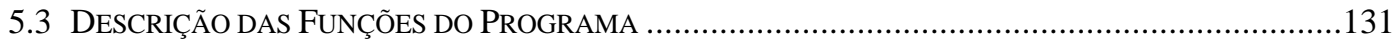

5.3.1 Dados de Entrada: Função Entra ..................................................................... 131

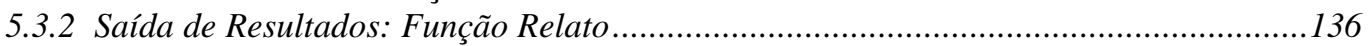

5.3.3 Funções Auxiliares ................................................................................................. 137

5.3.4 Dados Complementares Utilizados Por Algumas Funções.........................................137

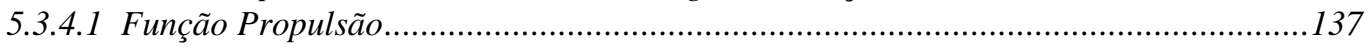

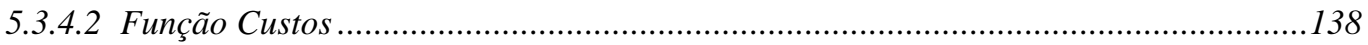

5.3.4.3 Função Ambiente ................................................................................................. 140

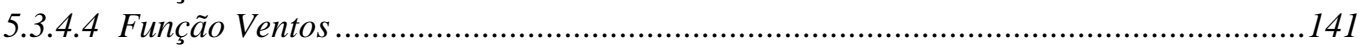

5.3.4.5 Função Pontes .............................................................................................. 142

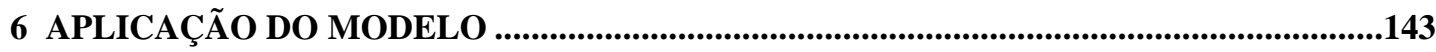

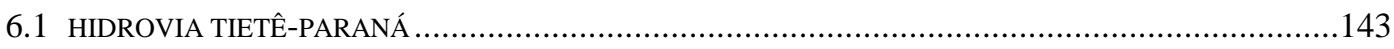

6.1.1 Descriçãodo Transporte ....................................................................................... 143

6.1.2 Investigação das Alternativas de Embarcações e de Procedimentos Operacionais.......145

6.1.2.1 Dimensões e Formações de Comboio..................................................................146

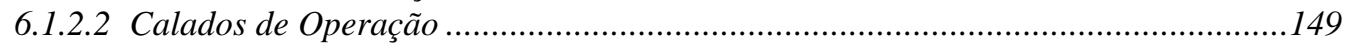

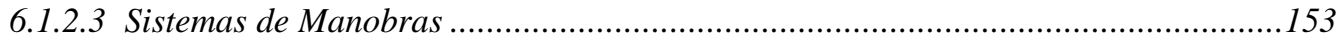

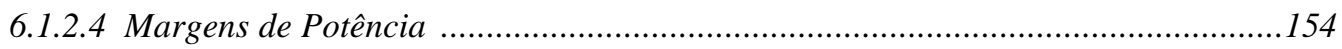

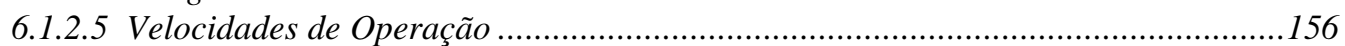

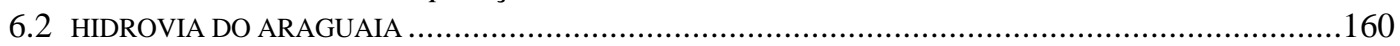

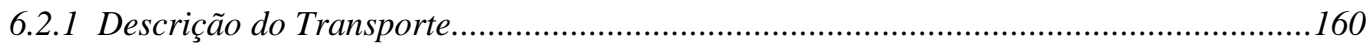

6.2.2 Estimativa de Custos de Transporte ....................................................................161

6.2 .3 Avaliação da Interferência Ambiental............................................................... 165

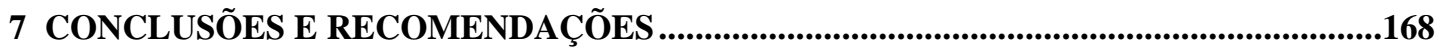

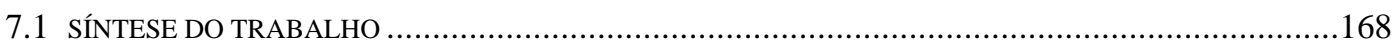

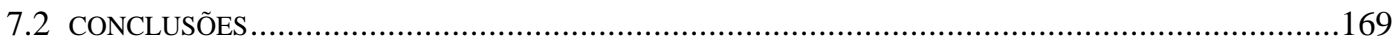

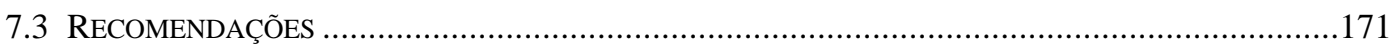

REFERÊNCIAS BIBLIOGRÁFICAS .............................................................................173

ANEXO A - HIDROVIAS BRASILEIRAS ......................................................................182

ANEXO B - UTILIZAÇÃO DE DADOS EXPERIMENTAIS....................................................192

ANEXO C - DADOS DE ACIDENTES COM COMBOIOS ......................................................202

ANEXO D - DADOS DE ENTRADA DO PROGRAMA ADAPTA ..........................................208

ANEXO E - LISTAGEM DO PROGRAMA ADAPTA ........................................................214 


\section{ÍNDICES DAS FIGURAS}

$\begin{array}{lll}\text { Figura 2.1 Visão de um sistema de transporte hidroviário. } & 12\end{array}$

Figura 2.2 Eficiência ideal e das séries sistemáticas B-Troost e Kaplan em função de coeficiente de carregamento $\mathrm{C}_{\mathrm{TH}}$ (Padovezi, 1997)

Figura 2.3 Representação esquemática das velocidades entre os fundos do rio e de um embarcação, a favor e contra a correnteza, $h$ é a profundidade do rio e H é o calado da embarcação (Lap, 1957)

Figura 2.4 Corrente de riscos de acidentes de embarcações

Figura 2.5 Exemplo de distribuição de acidentes por milhões de t.km em função da dimensão da embarcação e da dificuldade de passagem por determinado trecho do rio (Brolsma et al., 1988)

Figura 2.6 Boca virtual em função de deriva e da formação do comboio

Figura 2.7 Número de acidentes de comboios em pontes da Hidrovia TietêParaná

Figura 4.1 Distâncias de parada brusca de comboios obtidas 81 experimentalmente e com as equações adotadas pelo modelo

Figura 4.2 Efeitos da ação de ventos sobre comboio com chatas vazias

Figura 4.3 Coeficientes para estimativa de forças e momento devidos a ventos em comboios de quatro chatas vazias - 2 x 2 (Brolsma et al., 1998)

Figura 4.4 Determinação da probabilidade geométrica de colisão em pontos (AASHTO,1991), com adaptação para vãos reduzidos

$\begin{array}{lll}\text { Figura 5.1 } & \text { Entradas e saídas do programa ADAPTA }\end{array}$

$\begin{array}{lll}\text { Figura 5.2 } & \text { Encadeamento das funções do programa ADAPTA }\end{array}$

Figura 5.3 Estimativa de probabilidade geométrica PG de acidentes de um comboio de duas chatas em linha, passando sob a ponte da rodovia SP-461 sobre o Tietê

Figura 6.1 Variação do custo em função da velocidade média de viagem

Figura 6.2 Altura prevista de ondas em função da velocidade do comboio V e da distância à margem $\mathrm{S}$

Figura A.1 Bacias Hidrográficas do Brasil (Ministério dos Transportes)

Figura B.1 Ajuste dos valores de F da formulação de Howe com os ensaios com modelos em escala reduzida (IPT, 1970) - valores de F indicados na Tabela B.1 
Figura B.2 Potências obtidas em ensaios com modelo de comboio em escala 194 reduzida (IPT, 1970). Chatas LA-3: calados de 1,5m; comprimento de $54,2 \mathrm{~m}$ e boca de $10,0 \mathrm{~m}$; Chatas LA-5: calados de $2,5 \mathrm{~m}$, comprimento $56,5 \mathrm{~m}$ e boca de $10,0 \mathrm{~m}$

Figura B.3 Potências obtidas em ensaios com modelo de comboio em escala reduzida (IPT, 1970). Chatas LA-3: calados de 1,5m; comprimento de $54,2 \mathrm{~m}$ e boca de $10,0 \mathrm{~m}$; Chatas LA-5: calados de $2,5 \mathrm{~m}$, comprimento $56,5 \mathrm{~m}$ e boca de $10,0 \mathrm{~m}$

Figura B.4 Coeficientes de redução da força propulsora obtidos com 195 modelos de comboio em função da velocidade (IPT, 1970)

Figura B.5 Coeficientes de esteiras obtidos para o comboio Araguaia, chatas carregadas (Padovezi, 1997)

Figura B.6 Coeficientes de esteiras obtidos com modelo de automotor, em 196 função de h/T (IPT, 1973)

Figura B.7 Coeficientes de redução de força propulsora obtidos com modelo 196 de automotor, em função de h/T (IPT, 1973)

Figura B.8 Coeficientes de eficiência relativa rotativa obtidos com modelo de automotor, em função de h/T (IPT, 1973)

Figura B.9 Variações de coeficientes propulsivos em função da 197 profundidade, ensaios com modelo de automotor (IPT, 1973)

Figura B.10 Resultados de ensaios de manobras de giro com comboio em escala 1:6 pilotado no rio Tietê. Diâmetros de giro em função da formação do comboio $(\mathrm{n}=811 \mathrm{rpm})$

Figura B.11 Resultados de ensaios de manobras de giro com comboio em escala 1:6 pilotado no rio Tietê. Razões diâmetros de giro pelo comprimento do comboio

Figura B.12 Resultados de ensaios de manobras com comboio em escala 1: 6 pilotado no rio Tietê. Velocidade angular em função do ângulo de leme

Figura B.13 Ensaio de manutenção de rumo de comboio, em escala real, com duas chatas vazias em linha. Registros contínuos de velocidade angular, deslocamento e ângulo de lemes. Rio Tietê; ventos de intensidade moderada; sistema convencional de lemes e hélices

Figura C.1 Número de acidentes de embarcações em trechos difíceis e em trechos fáceis no rio Reno, período de 1966 a 1985 (Brolsma et al., 1988). Classe de deslocamento definida na Tabela C.1

Figura C.2 Acréscimos de acidentes por dificuldade de trechos e por classe 204 de deslocamentos (no trecho difícil). Rio Reno, período de 1966 a 1985 (Brolsma et al., 1988) 


\section{ÍNDICES DAS TABELAS}

Tabela 2.1 Interdependência das características das embarcações com as características das vias navegáveis e com a operação.

Tabela 2.2 Ondas calculadas em função da intensidade de ventos em pista do Reservatório de Promissão do rio Tietê.

Tabela 2.3 Relação das características das vias e seus efeitos e interferências sobre a segurança, meio ambiente e eficiência do transporte por embarcações

Tabela 2.4 Relação das possíveis soluções para enfrentamento de problemas de restrições nas vias navegáveis..

Tabela 2.5 Custos externos totais anuais com internalização de custos (Beuthe et al., 2002)

Tabela 3.1 Verificações das alternativas de projeto em função dos fatoresobjetivo do modelo proposto

Tabela 4.1 Valores do fator $\mathbf{F}$ da formulação de Howe, adotados no programa ADAPTA

Tabela 4.2 Comparações entre propriedades e características de sistemas de manobras (adotando valor 100 para os sistemas convencionais de lemes e hélices)

Tabela 4.3 Uma matriz de conseqüências de acidentes em hidrovia (USEG,2000)

Tabela 4.4 Uma matriz de freqüência de ocorrência de acidentes em hidrovia (USEG,2000)

Tabela 4.5 Caracterização gráfica do risco

Tabela 4.6 Resumo dos tipos de acidentes e faixas de freqüências e de suas conseqüências esperadas

Tabela 4.7 Pés-de-piloto mínimos adotados no modelo

Tabela 4.8 Dados de acidentes com comboios em quatro hidrovias (KitePowell et al., 1998), no período entre 1981 e 1995

Tabela 4.9 Fatores de aumento de probabilidade de colisões em pontes em função das condições de visibilidade, definidas como porcentagens do tempo em que há visibilidade menor que $1 \mathrm{~km}$ (Fujii \& Mizuki,1998)

Tabela 5.1 Funções do programa ADAPTA

Tabela 5.2 Valores de coeficientes de esteiras adotados - popa convencional

Tabela 5.3 Valores de coeficientes de redução de força propulsora adotados empurrador com popa convencional 
Tabela 5.4 Valores assumidos pela função custos

Tabela 5.5 Coeficientes obtidos em túnel de vento com modelo de comboio com chatas vazias (Brolsma et al. 1998)

Tabela 6.1 Alternativas que serão analisadas

Tabela 6.2 Comparações de opções de tamanhos de chatas na hidrovia TietêParaná ( 3 chatas de $40 \mathrm{~m}$ versus 2 chatas de $60 \mathrm{~m}$ )

Tabela 6.3 Comparações de opções de formação de comboios na hidrovia Tietê-Paraná ( 2 chatas em linha ou quatro chatas 2 x 2). Mesma potência instalada, calados de $2,5 \mathrm{~m}, 85 \%$ de disponibilidade da via

Tabela 6.4 - Comparações de opções de calados, formação de comboios com quatro chatas, mesma potência instalada, $85 \%$ de disponibilidade da via

Tabela 6.5 Probabilidades estimadas de acidentes em pontes da hidrovia TietêParaná (dados do período de 1994-1999)

Tabela 6.6 Comparações de opções de sistemas de manobras, formação de comboios com quatro chatas, mesma potência instalada, $85 \%$ de disponibilidade da via, calado de $2,7 \mathrm{~m}$

Tabela 6.7 Comparações de margens de potência instalada, formação de comboios com quatro chatas, mesma potência instalada, $85 \%$ de disponibilidade da via, calado de 2,7 m

Tabela 6.8 Comparações entre velocidades de operação, formação de comboios com quatro chatas, mesma potência instalada, profundidade $7,5 \mathrm{~m}, 85 \%$ de disponibilidade da via, calado de $2,7 \mathrm{~m}$

Tabela 6.9 Comparações entre comboios de mesmas velocidades, com taxas de embarques diferentes

Tabela 6.10 Variação de emissões de gases pelos motores, por ano, nas quatro alternativas

Tabela 6.11 Características do empurrador utilizado nos cálculos da Tabela 6.13

Tabela 6.12 Características das chatas utilizadas nos cálculos da Tabela 6.13

Tabela 6.13 Comparações de opções de pontal de chatas na hidrovia Araguaia. Comboio de quatro chatas, formação duas a duas, com empurrador da Tabela 6.11 e chatas da Tabela 6.12

Tabela 6.14 Comparações de desempenho de um comboio de duas chatas em linha com um comboio de quatro chatas $(2 \times 2)$. Pontal das chatas de $1,8 \mathrm{~m}$

Tabela 6.15 Características médias dos trechos entre Aruanã e Xambioá

Tabela 6.16 Comparações entre custos, com e sem restrições de velocidades em trechos sensíveis a ação de ondas provocadas pelo comboio 
Tabela A.1 Quantidade de cargas transportadas em hidrovias nos anos de 1998, 1999 e 2000

Tabela A.2 Principais rios navegáveis nas suas respectivas bacias

Tabela B.1 Valores do Fator F da Formulação de Howe, Obtidos a Partir de Comparação com Resultados de Ensaios em Tanque de Provas do IPT

Tabela B.2 Resultados de ensaios de giro com ângulo de leme de 35 graus e 811 rotações dos motores, modelo em escala $1: 6$ (Hirata, 2000)

Tabela B.3 Comboio de duas chatas em linha, vazias, medidas de manobra em escala real, hidrovia Tietê-Paraná

Tabela C.1 Classes de deslocamentos de embarcações e diferenças médias de acidentes em trechos difíceis e em trechos fáceis no rio Reno, período de 1966 a 1985 (Brolsma et al., 1988)

Tabela C.2 Dados de acidentes com comboios (Kite-Powell et al., 1998), no período entre 1981 e 1995

Tabela C.3 Colisões de comboios em pontes da hidrovia Tietê-Paraná

Tabela C.4 Acidentes em pontes da Hidrovia Tietê-Paraná

Tabela D.1 Posição e detalhes dos 17 trechos a serem percorridos pelo comboio

Tabela D.2 Pontes existentes entre Pederneiras e São Simão

Tabela D.3 Eclusas existentes entre Pederneiras e São Simão

Tabela D.4 Canais existentes entre Pederneiras e São Simão

Tabela D.5 Terminais utilizados entre Pederneiras e São Simão 


\section{LISTA DE SÍMBOLOS}

$\mathrm{A}_{0}$ - área do disco do hélice: $\mathrm{A}_{0}=\pi \cdot \mathrm{D}^{2} / 4$,

$\mathrm{A}_{\mathrm{E}}$ - área expandida do hélice,

$\mathrm{A}_{\mathrm{L}}$ - área do leme,

$\mathrm{A}_{\mathrm{P}}$ - área projetada das pás,

B - boca do comboio,

c - pé-de-piloto (distância vertical do fundo do canal à embarcação),

$\mathrm{C}_{\mathrm{TH}}-$ coeficiente de carregamento do propulsor: $\mathrm{CT}_{\mathrm{H}}=\mathrm{T} /\left(1 / 2 . \rho \cdot \mathrm{A}_{0} \cdot \mathrm{V}^{2}\right)$,

D - diâmetro do propulsor,

err - eficiência relativa rotativa (no programa),

et - eficiência de transmissão;

$\mathrm{F}_{\mathrm{nh}}$ - número de Froude de profundidade,

$\mathrm{g}$ - aceleração da gravidade,

h - profundidade do canal de navegação,

J - coeficiente de avanço do hélice,

$\mathrm{K}_{\mathrm{Q}}$ - coeficiente de torque do hélice, em água aberta,

$\mathrm{K}_{\mathrm{T}}$ - coeficiente de empuxo total do hélice,

m - massa total da embarcação,

n - número de rotações do hélice,

$\mathrm{P}$ - passo do hélice,

$\mathrm{P}_{\mathrm{B}}$ - potência do motor em unidades do S.I.,

$\mathrm{P}_{\mathrm{D}}$ - potência absorvida pelo hélice em unidades S. I.,

$\mathrm{P}_{\mathrm{E}}$ - potência efetiva do casco em unidades do S.I.,

$\mathrm{P}_{\mathrm{O}}$ - pressão estática referida ao centro do eixo do hélice,

$\mathrm{P}_{\mathrm{V}}$ - pressão de vaporização da água,

$\mathrm{Q}_{\mathrm{P}}$ - vazão de água devido ao propulsor,

$\mathrm{S}$ - perímetro da projeção lateral do comboio,

S - afundamento paralelo da embarcação ("squat"),

$\mathrm{S}$ - distância entre comboio e margens,

$\mathrm{t}$ - coeficiente de redução da força propulsora, 
T - calado médio de embarcação,

$\mathrm{T}$ - empuxo total fornecido pelo hélice,

$\mathrm{T}_{\mathrm{H}}-$ empuxo fornecido pelo duto,

V - velocidade da embarcação,

$\mathrm{V}_{\mathrm{A}}$ - velocidade de avanço: $\mathrm{V}_{\mathrm{A}}=\mathrm{V} .(1-\omega)$,

$\mathrm{Vp}$ - velocidade do jato de saída do propulsor,

W - largura média da via,

$\omega$ - coeficiente de esteira efetiva,

$\gamma$ - densidade da água,

$\rho$ - densidade específica da água: $\rho=\gamma / \mathrm{g}$,

$\eta_{D}$-eficiência propulsiva: $\eta_{D}=P_{E} / P_{D}$,

$\eta_{\mathrm{O}}-$ eficiência do propulsor em água aberta: $\eta_{\mathrm{O}}=\mathrm{J} \cdot \mathrm{K}_{\mathrm{T}} /\left(2 \cdot \pi \cdot \mathrm{K}_{\mathrm{Q}}\right)$.

$\eta_{R}-$ eficiência relativa rotativa;

$\eta_{\mathrm{h}}-$ eficiência do casco $=(1-\mathrm{t}) /(1-\mathrm{w})$;

$\eta_{R}-$ eficiência relativa rotativa

$\Delta$ - deslocamento da embarcação,

$1 / \mu$ - tempo médio de atendimento em eclusas ou em canais estreitos,

$\sigma$ - desvio padrão do atendimento em eclusas ou em canais estreitos,

$\lambda$ - fluxo médio de chegada de embarcações em eclusas ou canais. 


\author{
ABREVIATURAS \\ AASHTO - American Association of State Highway and Transportation \\ Officials \\ AHITAR - Administração da Hidrovia do Tocantins-Araguaia; \\ CCNR - Central Commission for the Navigation of the Rhine; \\ DH - Departamento Hidroviário, do Governo do Estado de São Paulo; \\ DPC - Diretoria de Portos e Costas, da Marinha do Brasil; \\ IALA - International Association of Marine Aids to Navigation and \\ Lighthouse Authorities; \\ IMO - International Maritime Organization; \\ IPT - Instituto de Pesquisas Tecnológicas do Estado de São Paulo; \\ ITTC - International Towing Tank Conference; \\ MT - Ministério dos Transportes do Brasil; \\ PIANC - Permanent International Association of Navigation Congresses; \\ RINA - Royal Institution of Naval Architects; \\ SNAME - Society of Naval Architects and Marine Engineering; \\ SOBENA - Sociedade Brasileira de Engenharia Naval; \\ SOLAS - International Convention for the Safety of Life at Sea; \\ USACE - United States Army Corps of Engineers; \\ USCG - United States Coast Guard; \\ US-EPA - United States Environmental Protection Agency; \\ VBD - Mitteilung der Versuchsanstalt für Binnenschiffbau e.v. Duisburg.
}




\section{INTRODUÇÃO}

Ao longo do tempo, a forma de utilização de rios e canais para a navegação comercial no mundo sofreu alterações que refletiram as condições e conjunturas técnicas, econômicas e políticas do momento.

Assim, nos primórdios dos tempos, quando não havia recursos tecnológicos suficientes, os rios eram utilizados exatamente no estado em que se encontravam. As embarcações eram projetadas e fabricadas da melhor forma possível para aproveitamento das características da via fluvial à disposição. Remos, varejões e velas eram utilizados como equipamentos propulsores de embarcações leves que tinham, na maior parte dos casos, que ser transportadas por terra no caso de ocorrência de um impedimento como corredeiras ou quedas d'água.

Com o incremento da navegação, principal forma de acesso a imensas regiões interiores ainda intocadas, os homens foram percebendo as vantagens de realização de obras para melhoria das condições de navegação. Assim, foram construídos os primeiros canais artificiais, as primeiras barragens com eclusas, foram feitas as primeiras escavações, enfim, foram realizadas obras com o objetivo de diminuir os esforços e os tempos necessários para os deslocamentos de cargas pelos rios.

O advento das grandes obras civis trouxe as barragens, formando grandes reservatórios com sistemas de transposição (eclusas), grandes obras de canalização de rios, retificações de traçados e aprofundamentos dos leitos, a fim de se garantir o 
maior gabarito possível para embarcações e comboios fluviais. Havia, em vários países, recursos técnicos adequados e uma decisão política e econômica de transformar rios em grandes hidrovias. Os rios, portanto, foram sendo adaptados às embarcações que eram consideradas as mais adequadas, do ponto de vista econômico, ao transporte fluvial, sem muitas preocupações com possíveis impactos ambientais. Grandes obras foram realizadas com o objetivo de eliminar as restrições à navegação.

Nos últimos anos, com a crescente importância dada aos impactos ambientais de obras de grande monta sobre os rios, tem sido adotado, de forma ainda difusa e desorganizada, o conceito de minimização da necessidade de intervenções (retificações, derrocamentos, dragagens) a partir da utilização de embarcações adaptadas às características das vias fluviais. Assim, tem sido buscado o menor impacto possível sobre as condições ambientais por meio da utilização da tecnologia moderna existente para os sistemas de propulsão e de manobras, e da revisão das dimensões e das próprias concepções de embarcações.

O Brasil, país de grande potencial hídrico, está desenvolvendo suas hidrovias mais tarde que aqueles países europeus e norte-americanos que utilizam, significativamente, a navegação fluvial como meio de transporte efetivo para cargas como granéis e containeres. Este atraso, contudo, faz com que o desenvolvimento das hidrovias brasileiras esteja acontecendo em um momento em que há um maior acúmulo de conhecimento científico e tecnológico sobre os impactos ambientais do transporte aquaviário, ao mesmo tempo em que aparecem equipamentos e materiais considerados mais apropriados para a construção e a operação de embarcações.

Neste contexto, o Brasil tem condições (e, de certa forma, obrigação) de explorar seu potencial hidroviário de maneira mais racional do que a maioria dos países que construíram suas hidrovias há mais tempo. Para tanto, é importante rever alguns conceitos de projetos de hidrovias, baseados exclusivamente na experiência européia e norte-americana de meados do século passado, e buscar uma nova concepção que, pela aplicação da tecnologia mais desenvolvida de projeto e construção de embarcações e de vias navegáveis, resultará em ganhos sociais e econômicos. 
As melhorias que devem ser buscadas continuamente, tanto nas obras realizadas na hidrovia como no projeto, construção e operação das embarcações, devem ter como objetivos inseparáveis, a eficiência e a segurança da navegação, assim como a minimização de impactos ambientais.

\subsection{A Navegação Fluvial}

Ao contrário dos oceanos, a maioria dos rios apresenta dificuldades importantes para a sua utilização como hidrovia, principalmente quando se deseja operar com embarcações de grande porte. Os rios apresentam condições de navegabilidade diferentes ao longo do ano, enquanto que o oceano proporciona condições operacionais praticamente permanentes. Nos rios, geralmente, aparecem restrições de profundidade, trechos estreitos, curvas fechadas, que exigem cuidados especiais com os sistemas de propulsão e de manobras das embarcações.

A busca da eficiência econômica do transporte utilizando os rios leva, invariavelmente, a compensar as baixas velocidades típicas de embarcações de carga com um grande volume transportado. Neste sentido, há sempre uma pressão econômica para operar com as maiores embarcações possíveis em determinado rio. As restrições físicas existentes, específicas de cada trecho do rio, são as balizadoras das dimensões das embarcações.

Profundidades, larguras, raios de curvaturas do eixo de navegação, correntezas, material do fundo, condições de visibilidade (presença de neblinas), possibilidade de ocorrência de ventos fortes e até de ondas, presença de troncos flutuando ou submersos, existência ou não de obras como barragens, eclusas e pontes, etc., são características da via navegável que interagem com qualquer embarcação que por lá trafegue, influenciando no seu desempenho e no seu comportamento. Se a embarcação for adequadamente projetada, construída e operada levando em conta todas as características importantes da via, tanto a segurança como a eficiência do transporte hidroviário estarão contempladas. 
Obviamente, várias restrições existentes em uma hidrovia podem ser eliminadas por obras. Devem ser realizados estudos para verificar as implicações de ordem econômica e ambiental, assim como para justificar a realização das obras que poderão contribuir para melhorar o desempenho das embarcações naquela hidrovia. Mas tais obras, exclusivamente para melhorar as condições de navegabilidade de uma determinada hidrovia, dificilmente serão de grande porte. A tendência é que sejam realizadas obras pontuais, localizadas, que buscarão eliminar certos gargalos, como trechos de baixa profundidade, com afloramentos rochosos ou com excesso de bancos de areia.

Derrocamentos e dragagens são, assim, as obras e intervenções mais comuns que têm ocorrido nos rios. Barragens com fins de geração de energia são obras que melhoram as condições de navegação, desde que sejam garantidos os meios para sua transposição (geralmente, eclusas). Nos tempos atuais, onde se busca o aproveitamento múltiplo eficiente dos rios, não há justificativas para a construção de barragens em rios navegáveis sem as eclusas correspondentes.

O ANEXO A apresenta as principais características das hidrovias no Brasil. De um modo geral, são poucas as hidrovias brasileiras que vêm sendo aproveitadas de maneira efetiva, havendo, contudo, um movimento coordenado, ainda que mais lento que o desejado, no sentido de promover o desenvolvimento do transporte hidroviário.

Excetuando os maiores rios da região amazônica, os demais rios brasileiros apresentam restrições físicas de alguma ordem, que podem, se não resolvidas, até inviabilizar a sua utilização como hidrovia para transporte de cargas. Na maior parte dos casos, contudo, são necessárias obras de pequeno porte para a transformação dos rios em hidrovias com garantia de determinado calado praticamente o ano todo. Em outros casos, as restrições existentes podem ser contornadas por soluções técnicas modernas e adequadas. Por exemplo, a implantação da navegação bem sucedida no rio Madeira de transporte de cargas a granel por comboios de chatas foi possível graças aos sistemas de propulsão e de manobras modernos (propulsores azimutais) instalados nos empurradores após estudo exaustivo em Tanque de Provas. Foram estudadas formas de chatas e formações de comboios, incluindo uma verificação 
experimental das melhores formas e arranjos de popas para evitar choques de troncos flutuando, muito comuns no rio Madeira, nos propulsores azimutais (Jukola \& Lindborg, 1999).

Há uma tendência crescente de utilização das hidrovias no Brasil, principalmente nas regiões onde há convergência de dois fatores: a existência de rios navegáveis em direções e extensões adequadas ao transporte das principais cargas regionais e a não concorrência exacerbada dos demais modais de transporte.

Embora sempre haja afirmações de que o transporte hidroviário apresenta menores custos que os transportes ferroviário e rodoviário, é importante notar que tais afirmações tendem a ser verdadeiras para os casos em que a logística está adequadamente resolvida. O transporte hidroviário, com poucas exceções, é dependente de integrações multimodais eficientes para fazer valer as suas qualidades de baixo custo de transportes.

As hidrovias da Amazônia, do Paraguai e parte da hidrovia do sul (Lagoa dos Patos) hoje dependem de outros modais apenas para concentrar e captar suas cargas nos portos de origem. As suas destinações finais são diretamente portos fluvio-marítimos. As demais hidrovias, como a Tietê-Paraná, dependem, de forma direta, de ferrovias ou rodovias para que os portos para exportação de suas cargas sejam alcançados.

Uma questão digna de nota é que o transporte de cargas pelas hidrovias brasileiras tem sido realizado de forma preferencial e, dependendo da hidrovia, exclusiva, por meio de comboios formados por empurrador e chatas. Esta tendência, inaugurada nos Estados Unidos e se estendendo por outros países, tem procurado explorar as vantagens da dissociação da parte ativa (empurrador) da parte passiva (chatas). A título indicativo, Planchar (1990) mostra as porcentagens de utilização de comboios para transporte de cargas em vários rios:

$\begin{array}{ll}\text { Rio Mississipi } & 95 \% \text {; } \\ \text { Rio Volga } & 65 \% \text {; } \\ \text { Rio Reno } & 30 \% \text {; } \\ \text { Canal Albert } & 20 \% \text {. }\end{array}$


No Brasil, nas hidrovias do Madeira, do Tietê-Paraná e do Paraguai-Paraná, praticamente $100 \%$ das cargas que percorrem maiores distâncias, são transportadas por comboios. Automotores são utilizados nas hidrovias do sul (Lagoa dos Patos e rios Jacuí e Taquari).

\subsection{Definição do Problema}

Conceitos e recomendações sobre como melhor adequar as embarcações à via existem de maneira esparsa. Há necessidade de agregá-los e organizá-los de tal forma que o conjunto seja visto de forma diferenciada. Afinal, é indispensável que a embarcação fluvial seja considerada como merecedora de projetos especiais que agreguem os resultados da evolução tecnológica, deixando de ser vista como algo resolvido, estático, que não é variável importante do problema de transporte. Na prática, verificada em vários casos, não se dá a importância devida à qualidade final da embarcação e, em conseqüência, durante décadas, se transporta com penalizações de eficiência. Por exemplo, comboios com chatas com peso excessivo de aço levarão, durante toda a sua vida útil, peso extra, que significará maior consumo de combustível. Se este consumo a mais for da ordem de 3\%, e o comboio operar por 30 anos, supondo um total de 4.800 horas por ano e uma potência total de $730 \mathrm{~kW}$, o combustível gasto a mais será da ordem de 700.000 litros; ou 23.000 litros por ano, por um "erro" comum.

As ineficiências e as incorreções, mesmo aquelas de pequena monta, podem resultar em perdas consideráveis quando são computadas por toda a longa vida útil das embarcações fluviais. Perdas que, dependendo do caso, podem ser de ordem econômica ou até de ordem ambiental. Há também os erros de concepção, de projeto, ou de construção, que tendem a elevar os riscos de uma embarcação sofrer um determinado tipo de acidente.

De certa forma, na equação da navegação fluvial, os pesos da qualidade e da concepção das embarcações têm sido minimizados. As concepções e as construções das embarcações fluviais são, via de regra, consideradas padronizadas, "de prateleira". 
Durante um longo tempo, poucas inovações foram implementadas nas embarcações fluviais de carga, particularmente nos comboios de chatas. Foram realizados poucos estudos técnicos sobre as formas padronizadas de seções retangulares dos cascos, sobre as linhas de proas e de popas de chatas e de empurradores, e sobre as relações das formas do comboio com as eficiências propulsivas resultantes. Afinal, durante décadas, as vias foram sendo moldadas para acolher a maior frota de chatas, com empurrador com grande potência instalada e sistemas complexos de lemes.

Neste sentido, aprofundamentos e retificações de canais facilitaram a utilização dos grandes comboios, onde as linhas de cada chata passavam a não fazer diferença no resultado do enorme conjunto. Qual a importância de uma linha de casco de chata se ela vai ser agrupada a outras dezenas?

A partir do momento em que, em muitos rios do mundo, não há condições de serem promovidas alterações radicais em seus canais navegáveis, a otimização das embarcações, em todos os seus aspectos, passa a ter grande importância. Não se trata mais de utilizar o maior comboio com chatas-padrão de décadas atrás, mas, sim, de buscar a embarcação mais adequada àquela via em questão. Volta, então, a importância de cada área da engenharia de embarcações, para que o resultado do sistema fluvial de transporte de cargas seja o melhor possível.

Por outro lado, as questões de preservação ambiental têm merecido destaque em todos os sistemas de transporte e, de uma forma mais incisiva, no transporte aquaviário brasileiro. $\mathrm{O}$ fato de se trafegar diretamente sobre a água, bem de importância ímpar para a vida da humanidade, aliado ao fato de vários rios brasileiros se situarem em regiões ainda pouco exploradas do território, faz com que a discussão sobre o transporte hidroviário no país esteja sempre ligada à questão ambiental.

Assim, à definição de embarcações adaptadas às vias, em busca de uma maior eficiência com maior segurança do transporte de cargas, deve ser agregada a visão que a adaptação da via também deve significar uma menor agressão ao meio ambiente. 
A prática, hoje, tem mostrado que, com raras exceções, armadores e operadores tendem a levar em consideração, no projeto e na operação das embarcações, quase que exclusivamente o desempenho econômico do transporte. Por outro lado, os órgãos de administração de hidrovias e os órgãos de regulamentação e de fiscalização do tráfego de embarcações, apresentam uma tendência de priorizar a questão da segurança da navegação. Alguns segmentos da sociedade, por sua vez, expressam preocupações com possíveis interferências ambientais da utilização dos rios como via de transporte.

Ocorre que as três preocupações (eficiência, segurança e meio ambiente) não são, necessariamente, antagônicas. Se um operador do sistema aumentar suas margens de lucro em detrimento da segurança, ele estará correndo riscos de, em um momento qualquer, ter de arcar com as conseqüências de algum acidente. Ou seja, ao longo do tempo, a opção de correr maiores riscos de acidentes pode se revelar anti-econômica. Se, por outro lado, algum órgão de regulamentação aumentar drasticamente as restrições à navegação, para que não haja qualquer possibilidade de ocorrência de acidentes, pode inviabilizar a atividade econômica, o que também pode ocorrer se for dado um enfoque desproporcional à questão ambiental.

Neste contexto, a fim de contribuir com o processo de evolução racional do sistema de transporte hidroviário de cargas, julga-se necessário o desenvolvimento de uma proposta de procedimentos de projeto que permita analisar, de uma forma integrada, a eficiência, a segurança e a questão ambiental.

\subsection{Objetivo do Trabalho}

O objetivo principal é mostrar que o projeto de embarcações fluviais de cargas, ou de um sistema hidroviário de transporte de cargas, deve ser desenvolvido levando em consideração, de uma forma integrada, três fatores: a eficiência, a segurança e o nível de interferência ambiental. 
Para atingir este objetivo, é elaborada uma proposta de procedimentos de projeto integrado que contempla os três fatores citados. O modelo é elaborado de modo a facilitar a compreensão da relação entre as características das embarcações e as especificidades das hidrovias, pré-requisito para uma otimização crescente do transporte fluvial.

Esta visão mais ampla do projeto deverá contribuir para a aproximação do enfoque principal, dado por armadores e operadores do transporte fluvial, de obtenção do melhor desempenho econômico possível, com as demais preocupações da sociedade, quanto aos riscos de acidentes de grandes proporções e aos problemas ambientais que possam ocorrer.

A idéia é fixar os comboios de empurra (chatas e empurradores) como as embarcações a serem estudadas, devido à sua importância indiscutível no segmento do transporte de cargas hidroviárias no Brasil. Mesmo assim, muitas considerações técnicas e conclusões que serão elaboradas para os comboios também serão aplicáveis aos automotores fluviais.

\subsection{Desenvolvimento do Trabalho}

O Capítulo 2 apresenta uma visão do sistema de transporte de cargas por navegação fluvial, no mundo e, de uma forma específica, no Brasil, focando os três aspectos considerados importantes: eficiência, segurança e respeito ao meio ambiente.

São descritas as características importantes das vias navegáveis, das embarcações fluviais de grande porte para transporte de cargas, os aspectos de segurança da navegação, assim como os impactos ambientais que ocorrem com a existência da navegação fluvial.

As interdependências entre as características das vias, das embarcações e de suas operações, são devidamente exploradas no Capítulo 2, já que constituirão a base para a elaboração da proposta de procedimentos de projeto integrado de embarcações, apresentada a partir do Capítulo 3. 
Ainda no Capítulo 2, é apresentada uma descrição do conjunto de custos externos que permeia a navegação fluvial, com o objetivo de ressaltar sua importância dentro do sistema de transporte de cargas e a necessidade de utilizá-los quando são feitas comparações entre os vários modais de transportes.

O Capítulo 3 apresenta o modelo de avaliação da relação entre embarcações e hidrovias, desenvolvido como um instrumento a ser utilizado para determinação do grau de adaptação de uma embarcação a uma determinada hidrovia.

O Capítulo 4 mostra uma descrição detalhada dos módulos do modelo elaborado, que inclui todos os fatores que influenciam na relação entre hidrovias e comboios.

O Capítulo 5 apresenta a implementação do modelo, por meio do desenvolvimento de um programa computacional, denominado ADAPTA, que utiliza a plataforma MATLAB. O programa foi dividido em 17 funções principais e 7 funções auxiliares, que englobam os aspectos considerados importantes para a análise da relação entre via e comboios fluviais, conforme apresentados no Capítulo 4.

O Capítulo 6 apresenta dois exemplos de aplicação do modelo, utilizando o programa computacional ADAPTA como ferramenta: um caso de transporte de soja na hidrovia Tietê-Paraná e um caso de transporte de grãos na hidrovia Tocantins-Araguaia. Também é feita uma análise dos resultados obtidos, que indicam as vantagens da adoção do projeto integrado de comboios fluviais, como proposto no presente trabalho.

O Capítulo 7 apresenta as conclusões sobre os resultados do estudo e recomendações e indicações para o seu aprimoramento futuro. 


\section{O SISTEMA DE TRANSPORTE POR NAVEGAÇÃO FLUVIAL}

\subsection{Visão Geral}

A Figura 2.1 apresenta uma visão do sistema de transporte em uma hidrovia, resultado da interação entre via e embarcações. Há os fatores agentes do sistema (operação, tripulação, equipamentos, dimensões e formas nas embarcações; restrições, obras, condições ambientais) e há os fatores resultantes (impactos ambientais das embarcações, das obras na via e do sistema inteiro; eficiência e condições de segurança do transporte).

Tanto a eficiência como a segurança da navegação e a interferência mínima com o meio ambiente serão resultantes da composição de vários fatores de integração da embarcação com a via navegável, como será visto adiante.

Os impactos ambientais que podem advir do transporte hidroviário apresentam três níveis diferentes:

○ impactos de obras de implantação e melhoria da hidrovia;

○ impactos da operação das embarcações;

o impactos resultantes do desenvolvimento regional provocado pela melhoria do transporte de cargas e ou de passageiros. 
Os impactos resultantes do desenvolvimento regional, de inegável importância, não serão objetos de estudo no presente trabalho, por tratar-se de assunto não especificamente ligado à navegação fluvial. Parte-se do princípio que a busca de melhoria de transporte em uma determinada região deverá fazer parte de um plano integrado de desenvolvimento, em que serão levados em conta todos os aspectos pertinentes, inclusive os impactos da aceleração da ocupação e da utilização de terras próximas aos rios. Do ponto de vista do transporte hidroviário, estritamente, serão considerados apenas os possíveis impactos ambientais da própria operação das embarcações. A avaliação dos possíveis impactos ambientais de obras em hidrovias não será objeto do presente estudo.

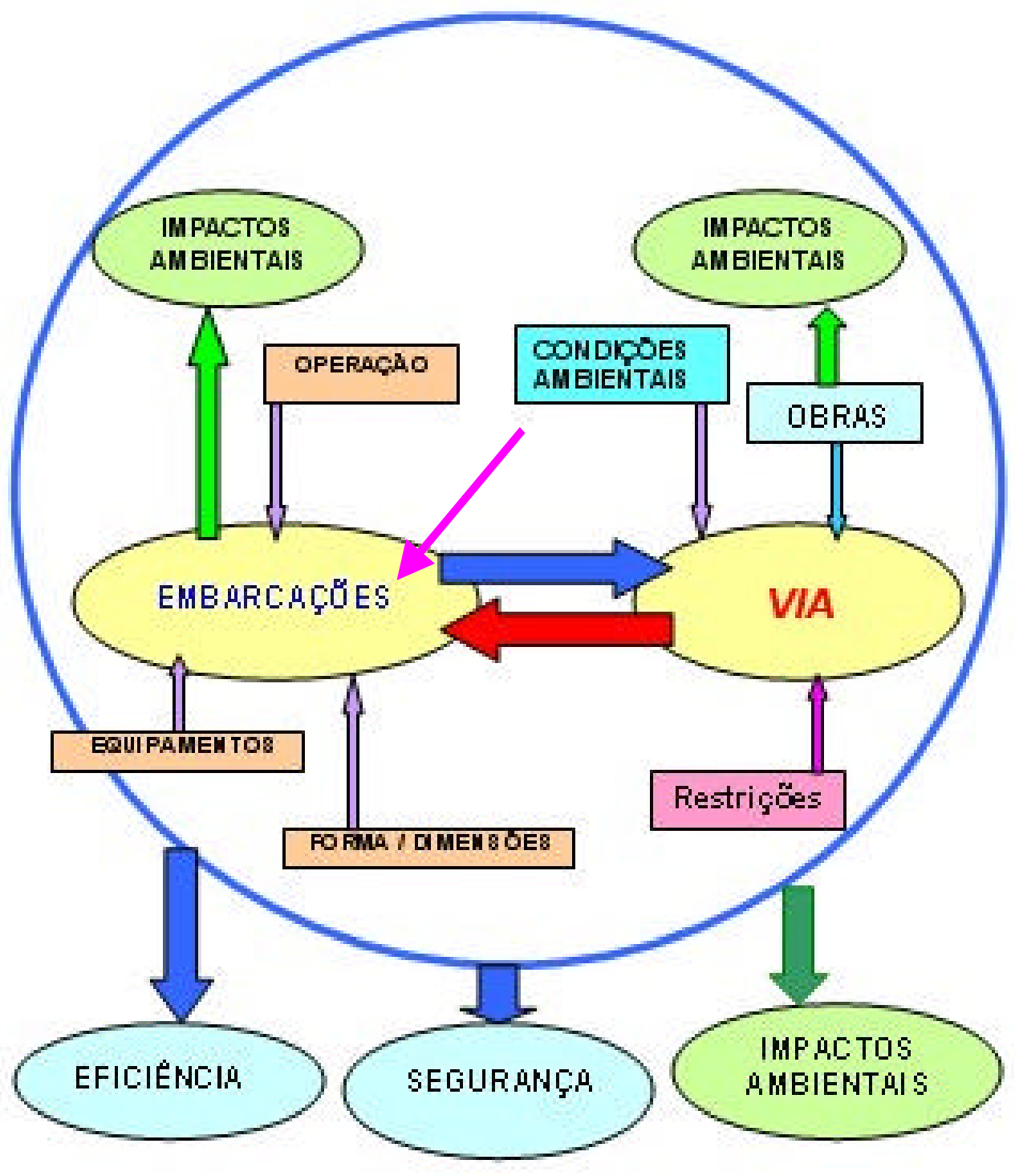

Figura 2.1 - Visão de um sistema de transporte hidroviário 
As melhorias que devem ser buscadas continuamente, tanto nas obras realizadas na hidrovia como no projeto, construção e operação das embarcações, devem ter como objetivos, a eficiência e a segurança da navegação, assim como a minimização de impactos ambientais.

Há necessidade de uma visão sistêmica de todo o entorno de um determinado rio. A navegação, por exemplo, é prejudicada por assoreamentos resultantes de má utilização do solo ribeirinho (desmatamentos, ocupação desordenada, etc.). Deve haver preocupações com relação à manutenção das margens, por meio de obras de contenção e de dissipação de energia de ondas provocadas por ventos e por embarcações, assim como por meio do controle do uso da terra ribeirinha e da conservação da mata ciliar.

Há, às vezes, a necessidade de obras ou intervenções que evitem a degradação ambiental e garantam a manutenção das condições de navegabilidade dos rios, o que permite afirmar que a preservação ambiental interessa diretamente à navegação. Um exemplo típico é a ocorrência de assoreamento em trecho de rio, impedindo a livre circulação de embarcações. Podem ser realizadas dragagens, para retirar a parte do material de assoreamento que interfere no canal de navegação. Contudo, se não forem eliminadas as causas, a operação de dragagem tenderá a tornar-se permanente porque o assoreamento continuará a ocorrer. Deve, então, ser estudada uma forma de intervir na área ribeirinha de modo que sejam controladas as causas do carreamento de material sólido para o rio.

Portanto, a própria via deve ser preservada. Não há sistema de transporte hidroviário que resista a um contínuo aumento do número de restrições à navegação. Antes, ou ao mesmo tempo, que for projetado um sistema de transportes para rios como o Araguaia e o São Francisco, por exemplo, devem ser aplicados recursos na preservação das margens e na minimização de assoreamentos. Como correr o risco de investir grandes recursos financeiros para implementar transporte em certo trecho de um rio se, poucos anos depois, as condições físicas (profundidade, traçado do canal de navegação, etc.) podem vir a impedir a continuidade do tráfego? 
Uma questão que se evita discutir é a restrição à intensidade de tráfego em hidrovias. É considerado que a introdução de restrições a priori poderiam afugentar investidores no modal de transportes. Ocorre que é salutar para os rios, para todo o sistema de transporte, e até para os empresários, que sejam colocadas abertamente todas as variáveis e limitantes do sistema. Em determinados rios que banham áreas de preservação, é possível evitar que as embarcações parem em trechos intermediários, só aportando em seus terminais de origem e destino, assim como é possível que seja controlado o número de embarcações que trafegam por lá.

Um rio como o Araguaia, por exemplo, deverá ter limites de tráfego de embarcações. Não se concebe que rios que devem preservar a qualidade de suas águas, sua flora submersa, seus peixes, etc., sejam submetidos a tráfego muito intenso de embarcações. Devem ser realizados estudos que indiquem um número máximo de embarcações, de um determinado porte e velocidade de cruzeiro definida, que possam passar por dia em qualquer trecho do rio. Neste sentido, uma embarcação de grande porte, se respeitados todos os limites (velocidade, distâncias de margens, etc.), interferirá no meio ambiente muito menos que várias embarcações menores.

Uma questão verificada na Europa é que há muitas embarcações menores, antigas, que induzem um tráfego elevado nos rios de maior importância econômica, aumentando a probabilidade de acidentes. No planejamento de uma hidrovia é possível pensar na utilização de um menor número de embarcações de grande capacidade de transporte de cargas, de forma a haver poucas embarcações trafegando em um mesmo trecho, com ganhos quanto à segurança da navegação e nos aspectos de interferência com o meio ambiente.

Um número excessivo de embarcações trafegando pode levar, dependendo das condições locais, a um grande volume de suspensão de sedimentos do fundo do rio e a interferência danosa na estabilidade das margens do rio. Se o transporte em uma hidrovia for realizado por um menor número de embarcações de alta capacidade de carga, não haverá muitos comboios passando em um mesmo dia em um mesmo trecho da via, o que, provavelmente, deve evitar interferências importantes na via, assim como deve diminuir a probabilidade de ocorrência de acidentes entre embarcações. 
Outra questão, quase tabu, não muito discutida, é o nível de utilização anual de uma hidrovia, ou seja, quantos dias por ano uma embarcação pode operar. Grandes obras são projetadas para garantir que as embarcações possam operar o ano todo. Obviamente, quanto maior tempo a embarcação puder operar, melhores serão os resultados econômicos do transporte. Porém, se não houver condições físicas para a operação em época de águas rasas, e não houver recursos financeiros ou condições técnicas ou de ordem ecológica para a execução de obras na via, pode ser possível dependendo da demanda por transporte na região, viabilizar um sistema de transporte que funcione plenamente, por exemplo, em oito ou nove meses por ano.

Há muitos rios no mundo em que o tráfego é interrompido em determinados períodos do ano. Por exemplo: certos rios russos e poloneses só são utilizados por cerca de seis meses, devido ao congelamento de suas águas; no rio Reno, durante dois a três meses, em período de águas baixas, os calados têm que ser reduzidos em até 50\%.

\subsection{As Embarcações e as Vias Navegáveis}

Do ponto de vista do sistema de transporte hidroviário, a via navegável apresenta as seguintes características físicas de interesse:

○ profundidades do canal de navegação;

○ velocidades de correntes;

○ raios de curvaturas presentes no traçado do canal navegável;

○ presença de pontos críticos ou com restrições (eclusas, pontes, canais estreitos, etc.);

○ grau de exposição a ventos e possibilidade de formação de ondas por ação de ventos;

○ suscetibilidade a alterações ambientais (possibilidade de desestabilização de margens, de interferência na fauna e flora submersas, etc.) provocadas pela passagem de embarcações;

○ alterações das condições de navegabilidade ao longo do ano, em função do regime de águas;

○ grau de manutenção das condições de navegabilidade ao longo do tempo (problemas de assoreamento, preservação de margens, etc.). 
Por outro lado, a passagem de embarcações em determinado trecho de rio, apresenta os seguintes fatores de interferência com a via:

* formas, dimensões e velocidades das embarcações, gerando ondas, que podem afetar a estabilidade das margens e provocando efeito de sucção no fundo do rio, inclusive pela ação de propulsores, que provocam suspensão temporária de material sólido na água;

* potências instaladas e manobrabilidades das embarcações, que têm ligação direta com o nível de riscos de ocorrência de acidentes em trechos mais críticos da via;

* densidade do tráfego, podendo intensificar os efeitos das passagens de embarcações e aumentando riscos de ocorrência de acidentes;

* possibilidade de poluição da água por óleo ou por rejeitos sólidos, por erros operacionais ou por acidente.

A Tabela 2.1 apresenta uma lista de características das embarcações e sua interdependência com as características da via navegável e com a operação. A embarcação é dividida, para avaliação, em três subsistemas ligados à sua concepção básica: casco, propulsão e manobras. Também é importante que seja levada em conta a operação, já que serão focados aspectos ambientais, de eficiência e de segurança, que, sem dúvida, são afetados significativamente pela operação da embarcação.

Durante o desenvolvimento do estudo, serão analisados apenas estes quatro itens para as embarcações, porque eles refletem e representam as variáveis de interesse para a avaliação da adaptação de uma determinada embarcação a uma via navegável.

Os demais itens de projeto de embarcações (estabilidade, estrutura, máquinas, arranjo geral, etc.) não serão objeto de detalhamento do presente estudo. Certamente, cada item destes tem sua importância e deve ser levado em consideração. Mas, no contexto da presente análise, podem ser resumidos de uma maneira prática e simplificada, como a seguir:

- estabilidade: basta fazer verificações, durante a fase de projeto, de regras específicas, devendo, contudo, haver um cuidado especial com os empurradores, para que não tenham bocas menores que as necessárias para a 
operação segura quando navegam em condição "escoteiro" (sem acoplamento a chatas);

- estrutura: a preocupação permanente deve ser com sua otimização, com relação a dimensões e a materiais, de modo que haja ganhos de produtividade pelo aumento da carga útil ("pay load"), obtido com a redução do peso do casco. O dimensionamento da estrutura deve levar em conta a possibilidade de encalhes da embarcação e, portanto, de esforços concentrados no fundo do casco;

- máquinas: uma vez determinados os sistemas de propulsão e de manobras, as máquinas devem ser escolhidas de forma a cumprir o seu papel com confiabilidade, segurança, pesos adequados, baixos níveis de ruído e baixas taxas de emissões de poluentes.

Tabela 2.1 - Interdependência das características das embarcações com as características das vias navegáveis e com a operação

\begin{tabular}{|c|c|c|}
\hline EMBARCAÇÃO & $\begin{array}{l}\text { VIA NAVEGÁVEL / } \\
\text { OPERAÇÃO }\end{array}$ & DETALHES \\
\hline \multirow{4}{*}{ CASCO } & RESTRIÇÕES DA VIA & Profundidades, larguras, curvas \\
\hline & ASPECTOS AMBIENTAIS & Interferência com fundo, ondas \\
\hline & \multirow{2}{*}{$\begin{array}{l}\text { EFICIÊNCIA DO } \\
\text { TRANSPORTE } \\
\text { (Fator de Mérito) }\end{array}$} & Carga útil x Velocidade \\
\hline & & $\begin{array}{l}\text { I.1.1.1.1 Potênc } \\
\text { ia }\end{array}$ \\
\hline \multirow{3}{*}{ PROPULSÃO } & VELOCIDADE MÁXIMA & \\
\hline & SEGURANÇA & Paradas, condições críticas \\
\hline & ASPECTOS AMBIENTAIS & Jato dos hélices, emissões \\
\hline \multirow[t]{2}{*}{ MANOBRAS } & RESTRIÇÕES DA VIA & \\
\hline & SEGURANÇA & $\begin{array}{c}\text { Condições críticas de navegação, } \\
\text { emergência }\end{array}$ \\
\hline \multirow{3}{*}{ OPERAÇÃO } & VELOCIDADE & \\
\hline & ASPECTOS AMBIENTAIS & $\begin{array}{c}\text { Lastreamento, condições } \\
\text { ambientais }\end{array}$ \\
\hline & SEGURANÇA & \\
\hline
\end{tabular}




\subsubsection{Subsistemas da embarcação}

\subsubsection{Cascos}

Os cascos de chatas e de empurradores têm sofrido um processo de padronização, até mundial, de linhas e de dimensões, por questões de facilidades de projeto executivo e de construção. A impressão que se tem é que o conjunto formado por um empurrador e por várias chatas acopladas, ora de uma maneira, ora de outra, resulta tão complexo e cheio de variáveis que induz à adoção de soluções prontas, já utilizadas em outras hidrovias. Um processo de otimização de um projeto específico para uma hidrovia exigiria, no limite, uma investigação experimental para a escolha das melhores formas de cascos para determinada aplicação naquela via.

Alguns estudos (Latorre et al., 1981; Werf, 1999) demonstram que alterações em formas de proas e de popas de chatas e otimização de linhas de popas de empurradores podem levar a ganhos significativos de eficiência. Werf (1999) mostrou que, aliando formas mais adequadas à otimização de peso estrutural dos cascos e a um arranjo de popa mais moderno, foram obtidos resultados importantes: cerca de $8 \%$ de aumento de carga útil do comboio e economia de combustível de até $15 \%$.

Cada hidrovia, com suas características de profundidades, larguras, correnteza, presença ou não de troncos flutuando, exige um cuidado específico com as linhas das embarcações, assim como com os apêndices que serão instalados nelas.

Em rios com restrições de profundidades, os empurradores devem possuir calado pequeno, para que possam trafegar também durante períodos de águas baixas. Há situações em que o calado mínimo operacional do empurrador é maior que o calado das chatas com carga parcial, impedindo a navegação do comboio em época de níveis baixos de água. A restrição à navegação do comboio passa, neste caso, a ser total quando poderia ser parcial, exclusivamente por conta dos problemas de dimensionamento do empurrador. 
No projeto e definição das formas da popa do empurrador, a utilização de túneis de popa permite que embarcações de baixos calados possam operar com diâmetros de propulsores um pouco maiores. Recomenda-se, contudo, a adoção de túneis após uma análise comparativa com outras alternativas de arranjo de popa. No caso do empurrador do comboio de pesquisas do rio Araguaia (Padovezi, 1997), por exemplo, as formas da saída dos túneis de popa chegaram a comprometer o desempenho propulsivo, resultando em forças verticais que tendiam a emergir a popa e imergir a proa do empurrador. A conclusão que se chegou é que uma popa com linhas mais convencionais e a adoção de menores diâmetros dos hélices poderia resultar em eficiência propulsiva maior que a obtida com túneis de popa e diâmetros praticamente iguais ao calado do empurrador.

A experiência de navegação por vários anos no rio Araguaia, com grandes bancos de areia e baixas profundidades, deu ao autor uma certeza sobre a inclinação lateral do fundo de chatas, que, geralmente, é introduzida com o objetivo de facilitar operações de desencalhes: as diferenças em eficiência em operações de desencalhes de chatas com fundos inclinados e chatas com fundos planos são praticamente inexistentes. Daí, passa a ser vantagem possuir chatas com fundos planos, sem inclinações, porque apresentam menores calados do que chatas com fundos inclinados, considerando uma mesma capacidade.

Quanto às dimensões dos cascos das chatas, é importante que sejam condicionadas às restrições principais da hidrovia. Uma eclusa é determinante: as dimensões de sua câmara deverão nortear a fixação das dimensões máximas principais dos cascos (bocas, comprimentos e calados). Os calados máximos das embarcações devem estar relacionados com as profundidades mínimas das passagens mais críticas, levando-se em consideração, inclusive, as variações de nível d'água durante o ano. A possibilidade de desmembramentos do conjunto de chatas pode proporcionar uma flexibilidade das dimensões do comboio, já que permite que passagens mais críticas à navegação sejam vencidas por um menor número de chatas por vez. 


\subsubsection{Propulsão e manobras}

Na presente análise não haverá separação dos sistemas de propulsão e de manobras, com o objetivo de evidenciar a ligação intrínseca entre estes sistemas. Há uma tendência crescente dos sistemas de propulsão e de manobras tornarem-se um único como é o caso de propulsores azimutais. Mesmo nos sistemas mais comuns, com hélices convencionais e lemes, a interação entre os seus componentes justifica a necessidade de estudá-los em conjunto, de uma forma integrada.

O arranjo da popa de um empurrador, onde geralmente convivem as linhas do casco, os eixos, os propulsores e os lemes, é um sistema complexo em que todos componentes exercem influência no comportamento global, interagindo com a via navegável (profundidade, correnteza, restrições de largura, ondas, etc.).

As embarcações fluviais de grande porte para transporte de cargas apresentam, de maneira geral, duas características importantes: baixos calados, como consequiência de restrições de profundidades de maior parte das hidrovias; grandes deslocamentos, resultantes da otimização econômica do sistema de transportes.

A conjunção de baixos calados com grandes deslocamentos leva a altos carregamentos nos propulsores das embarcações, porque a restrição de calados implica em limitações dos diâmetros dos hélices e grande deslocamento exige alto valor de empuxo para a embarcação operar em determinada velocidade.

O alto carregamento de um hélice sempre resulta em eficiência baixa (Padovezi, 1997), além de poder provocar problemas sérios de vibrações e de cavitação.

A eficiência ideal de propulsores é obtida pelas expressões (English, 1967), (Lewis, 1988):

$$
\begin{aligned}
& \eta_{I}=\frac{2}{1+\sqrt{1+C_{T H}}} \text { para hélices convencionais e } \\
& \eta_{I}=\frac{2}{1+\sqrt{1+\tau \cdot C_{T H}}} \text { para hélices em dutos, sendo: }
\end{aligned}
$$




$$
C_{T H}=\frac{T}{\frac{1}{2} \cdot \rho \cdot A_{0} \cdot V_{a}^{2}}
$$

e $\tau=\frac{T_{H}}{T}$, onde $\mathrm{T}$ é o empuxo total e $\mathrm{T}_{\mathrm{H}}$ é o empuxo fornecido pelo duto. $\mathrm{V}_{\mathrm{a}}$ é a velocidade de avanço; Ao é a área do disco propulsor $\left(=\pi \cdot \mathrm{D}^{2} / 4\right)$ e $\rho$ é a densidade específica da água.

A Figura 2.2 apresenta a eficiência ideal comparada com a eficiência em água aberta dos hélices das séries sistemáticas B-Troost e Kaplan (esta, em dutos). Os valores do coeficiente de carregamento $\mathrm{C}_{\mathrm{TH}}$ dos propulsores de comboios fluviais carregados se situam em uma faixa aproximada entre 4 e 9.

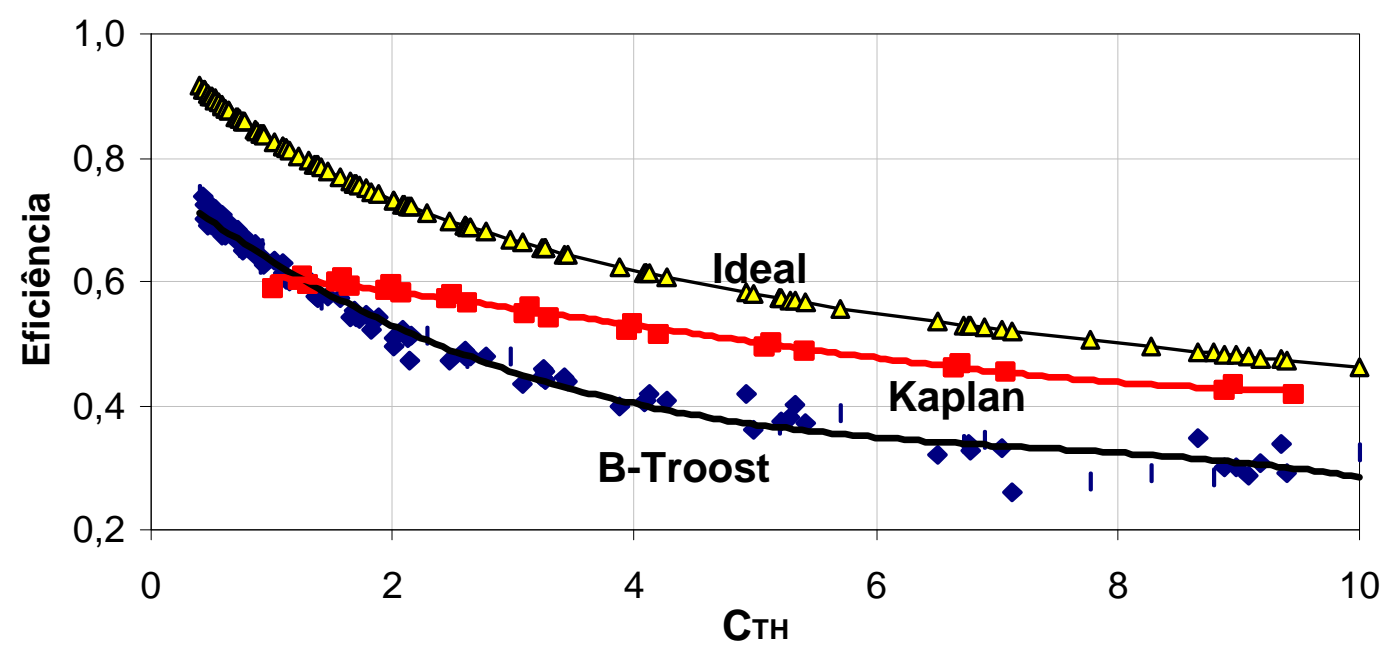

Figura 2.2 - Eficiência ideal e das séries sistemáticas B-Troost e Kaplan em função de coeficiente de carregamento $\mathrm{C}_{\mathrm{TH}}$ (Padovezi, 1997)

$\mathrm{O}$ denominado coeficiente propulsivo $\eta_{\mathbf{D}}$ correlaciona a potência efetiva do casco $\mathrm{P}_{\mathrm{E}}$ com a potência entregue pelos motores $\mathrm{P}_{\mathrm{B}}$ e tem a seguinte composição:

$$
\eta_{D}=P_{E} / P_{B}=\eta_{o} \cdot \eta_{R} \cdot \text { et } \cdot \eta_{h}
$$

onde $\eta_{\mathrm{o}}$ é a eficiência em água aberta do hélice; $\eta_{\mathrm{R}}$ é a eficiência relativa rotativa; et é a eficiência de transmissão; $\eta_{\mathrm{h}}$ é a eficiência do casco $=(1-\mathrm{t}) /(1-\mathrm{w})$; $\mathrm{t}$ é o coeficiente de redução da força propulsora e w é o coeficiente de esteira efetiva. 
Os coeficientes $\eta_{R}$ e $\eta$ h variam com a velocidade da embarcação, com a geometria e localização dos componentes do arranjo de popa, com alterações na formação de comboios de chatas e com mudanças de profundidades da via navegável.

Os coeficientes propulsivos $\eta_{\mathbf{D}}$ têm valores pequenos nas embarcações fluviais de grande porte, da ordem de 0,20 a 0,40 (Latorre, 1985). Provavelmente por conviver com tantas perdas, pouca importância tem sido dada aos efeitos dos diferentes arranjos de popa. Esta questão, contudo, deve ser enfrentada se há o desejo de obter ganhos de eficiência do sistema propulsivo.

Os lemes de flanco são lemes dispostos à vante dos propulsores, ao lado dos seus eixos, cuja finalidade é manter a governabilidade do comboio quando os hélices operam à ré. Nesta condição apresentam bom desempenho, porém, interferem negativamente nos coeficientes propulsivos com marcha à vante, porque bloqueiam o fluxo de água na popa, na região frontal dos hélices.

A substituição de lemes de flanco por "bow thruster" ou por propulsão azimutal leva a uma melhora imediata das condições de escoamento na popa, com ganhos em qualidade de manobra, assim como em incremento nos coeficientes propulsivos.

Vários (de dois a quatro) eixos com propulsores operando em paralelo sempre contribuem com a manobrabilidade; os dois propulsores das extremidades podem auxiliar no governo atuando alternadamente em marcha à ré. Neste caso, há necessidade da boca do empurrador ser relativamente grande. A propulsão múltipla além de aumentar a confiabilidade do sistema de propulsão, possibilita a utilização de menores diâmetros de propulsores e, conseqüentemente, de menores calados para os empurradores. Maiores bocas permitem maiores distâncias entre eixos, resultando em maiores momentos de giro e de manobra pela ação coordenada dos vários hélices. A utilização de propulsão múltipla, por outro lado, representa um aumento de peso e de custos da praça de máquinas.

A propulsão azimutal, isto é, o propulsor com atuação de um hélice convencional mas com a possibilidade de giro completo em torno de um eixo vertical, faz com que os 
problemas de manobra e governo tenham uma solução adequada. $\mathrm{O}$ acoplamento de um propulsor azimutal na proa do comboio pode aumentar a eficiência do sistema, permitindo melhores condições de manobra e governo ao comboio.

Com relação aos investimentos iniciais adicionais que seriam necessários para a instalação de equipamentos modernos de propulsão e de manobras, não se deve apenas levar em consideração o fator de aumento de custo (investimento inicial e manutenção). Devem ser analisados os ganhos significativos na operação, no aumento da segurança e na conservação ambiental.

Mais uma vez o caso da hidrovia do Madeira é exemplar. Se fossem construídos comboios de concepção tradicional com chatas do rio Mississipi e empurrador com hélices tradicionais e lemes de flanco, não haveria o sucesso atual obtido pelos comboios modernos com propulsão azimutal. Os empurradores convencionais teriam menores custos de construção, talvez cerca de $30 \%$ a menos, além de custos menores de manutenção, mas as vantagens operacionais e de segurança dos empurradores modernos devem cobrir rapidamente as diferenças entre os investimentos.

A utilização de hélices azimutais apresenta vantagem em outra questão relacionada à manobrabilidade, a parada brusca, por não despender tempo com a reversão de motores, como ocorre com os sistemas convencionais, já que basta girar em $180^{\circ}$ os eixos verticais dos hélices.

Os impelidores laterais ("bow thrusters") são equipamentos auxiliares de manobras, que proporcionam à embarcação uma força lateral na proa extremamente apropriada para acostagens laterais ou para compensar forças externas. Contudo, deve haver cuidado em sua utilização, pois existe um limite de velocidade da embarcação a partir da qual o "bow thruster" passa a não mais proporcionar força lateral adequada.

O projeto dos sistemas de propulsão e de manobras de um empurrador fluvial é feito, de forma ideal, a partir do pressuposto de uma formação do comboio de chatas que deverá trafegar, com uma velocidade média escolhida, por uma determinada hidrovia. Contudo, o empurrador pode vir a ser utilizado em comboios maiores que aquele de 
projeto ou em trecho de hidrovia com navegação mais crítica do que aquela do projeto inicial. Passa, assim, ser importante analisar, caso a caso, se há instalado um valor de potência mínima necessária para a navegação com segurança; tal potência mínima pode ser avaliada pela capacidade de parar a embarcação em uma situação de emergência (Padovezi, 2002).

Os seguintes fatores tendem a requerer sobre-potência dos motores:

profundidades muito reduzidas, menores que duas vezes o calado da embarcação;

* grande quantidade de curvas com raios de curvatura inferiores à cerca de quatro vezes o comprimento do comboio;

* velocidades de correntes altas;

correntes de través ocasionadas por tributários ou outros tipos de descargas, como vertedouros de barragens;

* grande volume de tráfego na via;

* possibilidade de cruzamentos de embarcações em canais restritos em profundidade ou largura;

obras de arte ao longo da via navegável, como pontes;

condições meteorológicas adversas, com ventos e ondas de magnitude relativamente grandes.

A manobrabilidade de grandes embarcações fluviais é resultado de vários fatores:

- a relação da potência instalada pelo deslocamento;

- tipo, número e arranjo dos propulsores;

- $\quad$ arranjo e eficiência dos lemes;

- perícia e treinamento dos pilotos;

- posição do centro de giro e exposição a esforços externos (ventos). 


\subsubsection{Operação}

Uma vez resolvida de forma consistente e eficiente a relação da embarcação com a via, o sistema físico de transporte de cargas estará bem encaminhado tecnicamente. Porém, ficaria faltando a operação do sistema que, dependendo de como é realizada, pode explorar todas as vantagens obtidas com a otimização do projeto da embarcação adaptada à via, ou tornar inúteis os esforços de incremento tecnológico.

A forma de operação é essencial e determinante para o sistema, como pode ser notado pelos seguintes aspectos:

- entre $60 \%$ e $85 \%$ dos acidentes que ocorrem em hidrovias têm como causas fatores humanos (erros, despreparo, má interpretação de situações críticas);

- o controle de velocidades operacionais em trechos críticos, tanto em relação à segurança quanto à interferência ambiental, é indispensável durante uma viagem de embarcação;

- um bom planejamento de embarque e desembarque de cargas de uma frota pode evitar congestionamentos e filas em pontos críticos como eclusas, trechos de passagens difíceis, etc;

- a manutenção periódica das embarcações garante uma continuidade sem sobressaltos da produção do sistema de transporte;

- $\quad$ procedimentos padronizados de carga e descarga das embarcações evitam problemas estruturais ou de estabilidade;

- a operação de comboios com chatas vazias traz preocupações extras quanto à segurança porque elas apresentam características de baixa manobrabilidade, grande área exposta ao vento, principalmente na direção lateral, e baixa visibilidade;

- devem sempre ser seguidos procedimentos adequados de navegação e de comunicação para o enfrentamento de situações com baixa visibilidade, ou com grande intensidade de ventos ou com tráfego intenso de embarcações; 
- a capacidade de lucro, ou ganhos, da embarcação depende da carga útil ("pay load"), dos custos operacionais e da flexibilidade do sistema. Estes três itens dependem da operação da embarcação: a carga útil pode ser maximizada pela adoção de um pé-de-piloto (a menor distância entre o casco e o fundo do rio) apropriado; custos operacionais estão diretamente ligados a tempos de viagens, a custos de manutenção e a consumos de combustíveis; a flexibilidade pode estar ligada à disponibilidade de chatas (algumas podem estar sendo carregadas ou descarregadas enquanto o empurrador transporta outras chatas);

- há trechos em que são necessários desmembramentos de comboios como, por, exemplo, em passagens estreitas em vãos de pontes ou em eclusas. Os acréscimos de tempos de tais operações podem implicar em perdas significativas da eficiência do sistema. Dependendo do caso, é possível haver um sistema auxiliar como, por exemplo, um empurrador de menor porte para auxiliar manobras de desmembramentos e passagens em trechos críticos.

\subsubsection{Características da via}

\subsubsection{1 Águas rasas}

A resistência de uma embarcação é fortemente modificada em águas rasas (restrição de profundidade). Há alterações no escoamento potencial junto ao casco, devido ao aumento da velocidade da água, quando comparada com o escoamento em águas profundas. Maior velocidade leva a menor pressão e a acréscimos de afundamento, de trim e de resistência ao avanço do casco (Lewis, 1988). Ocorre, também, uma variação sensível do trem de ondas gerado pela embarcação.

No caso de comboios, o escoamento resultante é mais complexo. Os propulsores do empurrador adicionam turbulência ao já perturbado escoamento devido às chatas. Dependendo da proximidade do comboio ao fundo do rio e das características do material do fundo do rio, uma quantidade de sedimentos é deslocada do fundo ou suspenso no escoamento. O material permanece em suspensão, até que a turbulência decaia o suficiente para permitir que ele decante. 
Ondas de proa são geradas em frente ao empurrador. Ondas menores são geradas nas laterais das chatas e nos bordos de ré das chatas são geradas as ondas de ré. As amplitudes das ondas são primariamente dependentes da velocidade da embarcação.

No caso de comboios, em que são desenvolvidas velocidades baixas, a tendência é que o efeito de sucção, que perturba o fundo do rio, seja preponderante quando comparado com a formação de ondas. Embarcações de alta velocidade, como lanchas, terão o efeito de formação de ondas mais acentuado que o de sucção.

Do ponto de vista de segurança, devem ser estudadas as variações nas respostas dos sistemas propulsivos e de manobras. Com relação à preservação ambiental, devem ser quantificados os graus de suspensão de sedimentos que possam causar danos a plantas aquáticas e a peixes. Como a suspensão de sedimentos se mantém à custa da turbulência, é muito importante a quantidade de embarcações que passam por um mesmo trecho de águas rasas. Se a frequiência for tal que mantém a suspensão por longos períodos, o problema ambiental local é mais severo do que uma situação onde existe tempo de decantação do material suspenso entre as passagens de duas embarcações.

\subsubsection{Larguras restritas}

A restrição de largura também implica em alterações do escoamento potencial ao longo do casco, de modo a alterar as respostas dos sistemas propulsivos e de manobras assim como a aumentar a resistência ao avanço.

A formação de ondas de comboios passando pelo local com restrição tem importância e pode, dependendo do caso, contribuir para a desestabilização de margens próximas. Torna-se importante o controle da velocidade de passagem por tais áreas para que a energia das ondas geradas não coloque em risco as margens do rio. Em caso deste tipo, como acontece principalmente na Europa, podem ser construídas proteções para estabilização das margens (por exemplo, gabiões) ou estruturas de dissipação de energia de ondas. 
Atenção especial sempre deve ser dada ao trânsito intenso de embarcações em trechos com restrições de larguras. Tanto o cruzamento como a ultrapassagem de embarcações, nesta situação, levarão à ampliação do risco de ocorrência de acidentes.

\subsubsection{Curvas fechadas}

Na maior parte dos rios em corrente livre do Brasil, há traçados do eixo de navegação com raios de curvatura relativamente pequenos (raios menores que três comprimentos da embarcação). Nestes locais, há dificuldades para as grandes embarcações fazerem as curvas, com velocidade de seguimento normal, o que leva a um acréscimo do risco de colisão com as margens, problema tanto relacionado com a segurança da navegação como com a preservação ambiental.

Obras para aumento dos raios de curvaturas têm uma certa envergadura, que exigem recursos financeiros consideráveis e uma alteração ambiental importante. Do lado das embarcações, trechos com curvas fechadas exigem excelente manobrabilidade, o que deve implicar em equipamentos especiais, como, por exemplo, impelidores laterais ("bow thrusters") e hélices azimutais.

Sistemas convencionais de manobras dificilmente respondem bem a situações que exigem altas velocidades angulares durante as manobras. Se as embarcações contam apenas com tais sistemas, em algumas situações mais críticas são obrigadas a, praticamente, estancarem as suas marchas e, com cuidado e devagar, fazer as curvas sem colidir com as margens.

\subsubsection{Obras de arte}

Pontes e eclusas são as obras em hidrovias que mais exigem atenção especial durante a passagem de grandes embarcações por elas.

As entradas de eclusas por montante da barragem, porque têm grande volume de água e grandes larguras, geralmente apresentam dificuldades para a aproximação de embarcações quando há ventos e ondas. Lança-se mão de muros-guia, que, dispostos 
junto a um lado da entrada das eclusas, servem de apoio para a entrada precisa das embarcações.

Com relação às pontes, quando os vãos horizontais entre pilares são relativamente pequenos, há grandes riscos de colisão de embarcações com pilares (ver item 2.4.3). E colisões de embarcações em pilares de pontes apresentam um enorme risco de perda de vidas e grandes perdas econômicas, já que podem derrubar tabuleiros, interrompendo abruptamente a continuidade da via rodoviária ou ferroviária sobre a ponte.

\subsubsection{Locais com formação de ondas por ventos}

Em trechos de rios com grandes larguras podem ocorrer pistas ("fetches") favoráveis à formação de ondas pela ação de ventos. Há formações de ondas em certos trechos do rio Amazonas, da Lagoa dos Patos e em alguns reservatórios dos rios Tietê, Paraná e São Francisco. Dependendo da velocidade dos ventos, ocorre formação de ondas com alturas tais que prejudicam a navegação, aumentando a resistência ao avanço e os esforços nas amarras dos comboios, até colocando em risco a segurança da navegação.

A Tabela 2.2 mostra as características de ondas esperadas em um trecho do reservatório de Promissão no rio Tietê em função das velocidades dos ventos (IPT, 1986).

Tabela 2.2 - Ondas calculadas em função da intensidade de ventos em pista do reservatório de Promissão no rio Tietê (IPT, 1986)

\begin{tabular}{c|c|c|c}
\hline VENTO & \multicolumn{3}{|c}{ ONDAS } \\
\hline Velocidade $(\mathrm{m} / \mathrm{s})$ & Período (s) & Comprimento (m) & Altura (m) \\
\hline 4,5 & 1,75 & 4,80 & 0,22 \\
\hline 8,9 & 2,40 & 9,00 & 0,56 \\
\hline 13,4 & 2,80 & 12,20 & 0,79 \\
\hline 17,9 & 3,20 & 15,90 & 0,95 \\
\hline 22,3 & 3,50 & 19,10 & 1,18 \\
\hline 26,8 & 3,80 & 22,60 & 1,49 \\
\hline
\end{tabular}




\subsubsection{Condições ambientais adversas}

Parte significativa das causas de acidentes com embarcações fluviais está relacionada com condições ambientais adversas. Falta de visibilidade e ocorrência de ventos de altas intensidades podem levar a perdas de controlabilidade da embarcação e ao aumento de riscos de ocorrência de acidentes.

As embarcações devem possuir sistemas eficientes de navegação (radar, GPS) e de comunicação (rádio) para poderem evitar, se possível, certas situações de risco e, se forem colhidas de surpresa, poderem enfrentar com segurança uma situação crítica de navegação.

Ganham importância, também, a concepção e a operação dos sistemas de propulsão e de manobras, para fazer frente a situações, por exemplo, com ventos intensos de través em trechos estreitos de hidrovias.

\subsubsection{Altas velocidades de correntes}

Uma característica da navegação fluvial é a presença de velocidades de correntes relativamente altas. Exceções são as navegações em reservatórios ou lagos formados por barragens, onde o represamento da água faz com que as velocidades de correntes sejam pequenas.

No caso de rios com reservatórios, só ocorrem velocidades de correntes altas nos trechos imediatamente a jusante de uma barragem porque ainda não há grande influência do reservatório da próxima barragem e existe o efeito direto das descargas das turbinas e dos vertedouros.

Quando há velocidades de correntes, as condições de navegação contra e a favor da correnteza são muito diferentes entre si. A Figura 2.3 (Lap, 1957) apresenta um diagrama de distribuições de velocidades do escoamento entre o fundo do rio e o fundo de uma embarcação, em seguimento a favor e contra a correnteza. Em águas calmas, ocorre praticamente o que ocorre na soma das duas condições, contra e a favor da correnteza. 
Como na maioria das hidrovias brasileiras ainda há, praticamente, cargas em um único sentido, sem cargas de retorno, as condições de navegação em uma viagem redonda são desiguais. Em alguns rios, as cargas são transportadas contra a correnteza, e em outros (na maior parte), os comboios com deslocamentos carregados trafegam a favor da correnteza.

Com relação à manobrabilidade, existem melhores condições de controle da embarcação quando a viagem é realizada contra do que a favor da correnteza, considerando uma mesma velocidade referenciada à terra, porque a velocidade relativa na embarcação, e nos lemes, na condição contra a correnteza será maior.

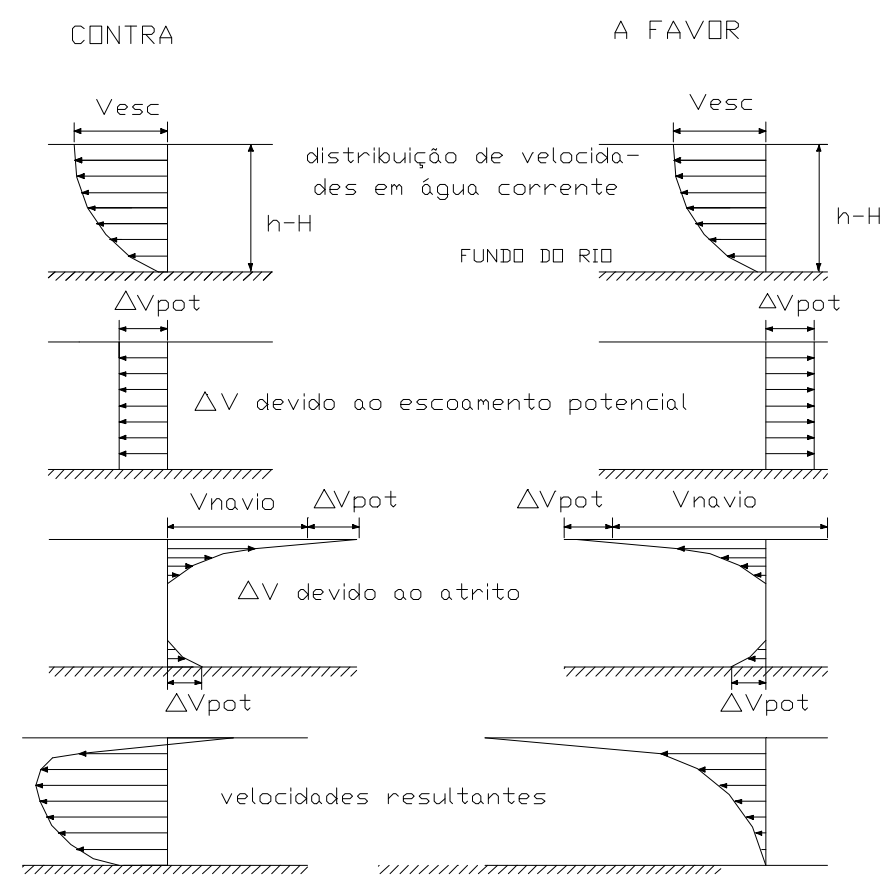

Figura 2.3 - Representação esquemática das velocidades entre os fundos do rio e de uma embarcação, a favor e contra a correnteza; h é a profundidade do rio e H é o calado embarcação (Lap, 1957)

\subsubsection{Grandes variações de nível d'água ao longo do ano}

Nas hidrovias brasileiras em rios sem barragens, há grandes variações de níveis d'água ao longo do ano. Na região amazônica, onde as variações são as maiores do Brasil, as diferenças de níveis entre períodos de cheias e de estiagem chegam a 15 metros em alguns rios. 
As embarcações devem ser projetadas para operar nos vários níveis de água. De preferência, devem ser levantados os tempos em que as embarcações operarão em cada nível d'água para que as soluções adotadas sejam devidamente ponderadas.

Uma boa providência é projetar o empurrador com pequeno calado, para que possa operar em águas baixas mesmo que as chatas tenham que receber carga parcial. Se houver coincidência da época de estiagem com a maior demanda de transporte de cargas, as chatas devem ser projetadas de forma otimizada para a operação em águas rasas. Dependendo de resultados de estudos econômicos, podem ser utilizadas chatas com dimensões e capacidades diferentes, de acordo com a época do ano.

\subsubsection{Materiais flutuando}

A presença de troncos de árvores flutuando em rios é relativamente comum em épocas em que se inicia o período de chuvas. Árvores caídas nas margens durante o período de estiagem são colhidas pelas enchentes e levadas ao leito dos rios, com tendência, inclusive, de serem transportadas até o centro do canal navegável, porque geralmente representam as seções de velocidades de correntes mais altas.

Troncos podem causar danos aos cascos mais frágeis mas, o maior perigo potencial é a sua colisão com hélices e lemes nas popas das embarcações, podendo inviabilizar até o prosseguimento da viagem. Alguns estudos têm sido realizados para determinação de linhas de cascos que desviem os troncos, a fim de evitar sua sucção pela popa das embarcações propelidas (Jukola \& Lindborg., 1999).

Uma solução às vezes utilizada é a instalação, à frente dos hélices, de sistemas protetores contra colisão de objetos. Estas estruturas geralmente implicam em aumento significativo da potência requerida, quer pelo acréscimo de resistência ao avanço da embarcação, quer por alterações dos coeficientes propulsivos.

\subsubsection{0 Áreas de preservação ambiental}

Muitos rios brasileiros passam por áreas de preservação ambiental, onde há aldeias indígenas, santuários ecológicos, etc. Rios como o Araguaia, o Paraguai e até o 
Paraná (no trecho de Ilha Grande) precisam ser vistos de forma diferenciada dos demais.

Em princípio, as obras que, provavelmente, serão realizadas nestes locais não deverão ser de grande porte, e nem resultar em grandes impactos ambientais. Serão, ao contrário, pequenas obras, como dragagens ou derrocamentos em trechos curtos, para eliminar pequenas restrições locais à navegação.

A adoção de tecnologia moderna de embarcações e de providências operacionais adequadas pode resolver a questão da passagem de uma hidrovia por um determinado lugar que se pretende preservar. Embarcações com dimensões adequadas e velocidades máximas fixas, com pequeno nível de ruído e baixas taxas de emissão de poluentes na atmosfera, podem ser utilizadas. Como procedimentos para preservação ambiental, podem ser proibidas paradas das embarcações fora dos terminais de embarque e de desembarque das cargas.

As embarcações apresentam a vantagem de possuir grande autonomia e tripulações que se revezam em turnos, podendo passar semanas sem parar em qualquer ponto das margens, evitando maiores impactos em áreas que se deseja manter intocadas o máximo possível.

\subsection{O Transporte Hidroviário e a Questão Ambiental}

As embarcações são responsáveis por um certo número de impactos ambientais, como: poluição do ar, interferência no meio causada por esteiras (formação de ondas e turbilhonamento na água), descartes de rejeitos sólidos e de esgoto. Pode ocorrer, ainda, a introdução de espécies não nativas de organismos devido ao despejo de águas de lastro trazidas de outros locais, assim como pode haver derramamentos acidentais de produtos perigosos (US-EPA, 1999).

Os impactos ambientais do transporte hidroviário variam de rio para rio, de um projeto de transporte para outro. Algumas vias apresentam uma suscetibilidade maior que outras à ação de fatores que causam impactos: margens sujeitas a instabilidades, possibilidade de interferências no ciclo de vida de espécies subaquáticas, etc. 
A seguir serão detalhados os impactos ambientais, considerados mais importantes, que podem ser provocados por embarcações nos rios do Brasil. Também são citadas as ações indicadas para a minimização dos impactos. Os impactos são baseados no documento US-EPA (1999), adaptados às características da navegação fluvial brasileira..

\subsubsection{Poluição do ar}

Forma de impactos:

- emissões de hidrocarbonetos (HC), monóxido de carbono (CO), óxidos de nitrogênio (NOx), dióxido de enxofre $\left(\mathrm{SO}_{2}\right)$ e material particulado.

Fatores que afetam o impacto ambiental:

número de viagens das embarcações e distâncias percorridas;

emissões por volume de combustível consumido;

$>$ tipo das máquinas, idade e tecnologia de controle de emissões;

sensibilidade do eco-sistema local;

$>$ condições de dispersão dos poluentes (vento, temperatura, chuva, etc.);

densidade populacional junto às margens das hidrovias.

Ações para minimização dos impactos:

- Os motores modernos devem possuir baixa taxa de emissão de poluentes, seguindo recomendações e referências existentes. Por exemplo, no rio Reno, há em vigor uma norma de emissões máximas para motores em embarcações fabricadas a partir de 1 de janeiro de 2002, com um tempo máximo de dez anos para o enquadramento de motores antigos (CCNR, 2002).

- Deve ocorrer manutenção periódica dos motores, com preocupações quanto à regulagem e à emissão resultante.

- Podem ser adotados combustíveis menos poluidores. No Brasil, seria possível adotar em alguma região especial, que tenha restrições severas de 
poluição do ar, álcool, com aditivos, como combustível (Padovezi \& Giraldo, 1986).

- Deve haver controle do número de embarcações em tráfego em determinados trechos mais suscetíveis à poluição do ar.

\subsubsection{Impactos devidos às esteiras das embarcações}

Formas de impactos:

- erosão em margens;

- revolvimento de material do fundo do rio, em águas mais rasas;

- interferência com a vegetação, tanto pelo processo de erosão como de sedimentação provocadas pelas esteiras;

- a sedimentação em locais rasos e com muito tráfego de embarcações reduz a quantidade de luz solar necessária aos processos de fotossíntese.

Fatores que afetam o impacto ambiental:

$>$ volume de tráfego de embarcações;

$>$ dimensões e velocidades das embarcações;

sensibilidade do eco-sistema local às interferências físicas.

Ações para minimização dos impactos:

- Deve haver controle do número de embarcações, evitando tráfego muito intenso;

- Em locais estreitos ou rasos, as velocidades de passagem das embarcações devem ser mais baixas. Estas velocidades devem ser calculadas também em função das dimensões das embarcações;

- Em locais estreitos, com tendência de erosão em margem, pode haver construção de sistemas de proteção de margens, expediente muito utilizado em hidrovias européias (Brolsma et al., 1988). 


\subsubsection{Derramamentos de óleos e de outros produtos perigosos}

Formas de impactos:

- contaminação da água, afetando a fauna e a flora local e a utilização da água para outros fins (abastecimento, irrigação, pesca, lazer, etc.);

- desequilíbrio do eco-sistema local, junto às margens;

- prejuízo à saúde das pessoas que vivem junto ao local.

Fatores que afetam o impacto ambiental:

quantidade de produtos perigosos transportados;

$>$ acidentes com embarcações e derramamentos de produtos perigosos;

$>$ toxidade e periculosidade dos produtos derramados;

disponibilidade de pessoal e de equipamentos para imediata limpeza da água contaminada.

Ações para minimização dos impactos:

- Adoção de embarcações especiais para transporte de produtos perigosos, como embarcações construídas com cascos duplos.

- Aumento do nível de segurança, pela utilização de embarcações adequadas, fiscalizadas e com operação realizada por tripulações bem treinadas, contando com equipamentos adequados.

- Providências preventivas como instalação de barreiras flutuantes ao redor das embarcações podem evitar danos ambientais em caso de acidente, pois uma grande parte dos derramamentos de óleos ocorre nos terminais, durante as operações de carga e descarga.

\subsubsection{Impactos devidos à introdução de espécies não nativas}

Formas de impactos:

- despejo de água de lastro carregada em local distante, com probabilidade de transporte de organismos não nativos à região de descarte, com 
possibilidade de introdução de fator de desequilíbrio ambiental local. Por exemplo, vários pesquisadores atribuem à água de lastro a disseminação do vibrião colérico, que já estava praticamente sob controle no mundo, mas ainda era um problema sanitário na Índia. Esses cientistas acreditam que os porões de navios de carga transportaram, junto com a água de lastro, o vibrião que chegou ao Peru e, de lá, espalhou-se pela América Latina;

- espécies não nativas podem competir com espécies existentes no local, podendo resultar em significativas alterações no eco-sistema aquático.

Fatores que afetam o impacto ambiental:

número de embarcações que carregam água de lastro;

falta de regulamentação e acompanhamento do descarte de água de lastro.

Não há dados disponíveis de avaliações dos impactos ambientais por deposição de água de lastro em rios brasileiros. Um exemplo conhecido é nos Grandes Lagos americanos, onde se contabilizou a introdução de mais de 130 espécies não nativas desde o ano de 1800, sendo estimado que, pelo menos, um terço dos casos foi transportado por embarcações (US-EPA, 1999).

Ações para minimização dos impactos:

- Dentro das possibilidades, geralmente ditadas por questões de segurança de navegação, deve ser evitada a utilização de lastros. Se for indispensável a utilização de lastro, devem ser previstas formas de descarte controlado, após tratamento químico da água.

- Uma solução que tem sido adotada para controle da água de lastro é a sua contínua substituição durante a viagem, de forma que, ao chegar ao destino, a água é praticamente da mesma região do destino.

- Atenção especial deve ser dada aos navios oceânicos, incluindo navios estrangeiros, que trafegam pelos rios brasileiros, particularmente na Amazônia, rios Paraguai e Paraná e Lagoa dos Patos. 


\subsubsection{Descarte de resíduos sólidos e esgotos}

Formas de impactos:

- poluição da água, com possibilidade de introdução de patogênese microbial e redução do oxigênio dissolvido na água;

- $\quad$ possibilidade de ingestão por peixes e animais diversos.

Fatores que afetam o impacto ambiental:

número de embarcações que trafegam pela área;

falta de instrução e fiscalização das ações da tripulação;

falta de equipamento para armazenamento e transferência de resíduos para tanques especiais em terra (geralmente, nos terminais).

Ações para minimização dos impactos:

- As embarcações devem possuir tanques para armazenamento de esgoto tratado e de resíduos sólidos.

- Os terminais devem ter equipamentos e depósitos para bombear e receber resíduos armazenados nas embarcações.

\subsection{A Segurança da Navegação}

A segurança da navegação é o contraponto da operação mais lucrativa possível das embarcações. Uma busca exclusiva do maior lucro levaria a embarcações com carregamentos excessivos, operação temerária, sistemas sem manutenção adequada, ou seja, com tudo que poderia aumentar os ganhos e diminuir despesas.

Felizmente, a segurança da navegação é feita pela aplicação de muitas regras criadas e aperfeiçoadas ao longo do tempo, tanto por organismos internacionais (IMO, SOLAS) como por órgãos nacionais (DPC da Marinha do Brasil). Assim, tanto aspectos relacionados com o projeto, construção e operação das embarcações, como com balizamentos e sinalização de vias, têm a devida regulamentação que, se cumpridas, garantem uma segurança adequada, na maior parte dos casos. De uma 
certa forma, pode-se afirmar que a maioria das regras existentes foi criada para aplicação em embarcações marítimas.

Acontece que a navegação fluvial apresenta muitos problemas específicos de segurança, que merecem ser estudados à parte, com o objetivo de aprimorar a segurança e minimizar os riscos de ocorrência de acidentes. Passagens de comboios sob vãos estreitos de pontes, cruzamentos entre embarcações em trechos de rios com restrições de larguras e de profundidades, operações de desmembramentos de comboios para possibilitar a passagem por determinado ponto crítico de uma hidrovia, forma de amarração entre chatas e empurradores, etc., são itens que têm merecido atenção dos órgãos responsáveis pela segurança de navegação fluvial.

No Brasil, é muito destacada a evolução, nos últimos anos, das normas específicas das capitanias fluviais da Marinha do Brasil, coincidindo justamente com o aumento de atividade de embarcações de grande porte em muitas hidrovias (Tietê-Paraná, Paraguai-Paraná, Madeira). Fica evidente que há um processo contínuo de aprimoramento e de criação de regras a partir dos problemas novos surgidos na navegação fluvial.

Apesar das regras específicas existentes para a segurança da navegação, os projetistas e operadores de embarcações devem possuir uma análise própria das causas e dos conseqüentes riscos de ocorrências de acidentes na hidrovia de seu interesse. A seguir, será apresentada uma visualização do encadeamento de causas e fatores que podem levar à ocorrência de acidentes com uma embarcação; logo após, serão apresentadas considerações particulares sobre segurança de embarcações fluviais de grande porte e, finalmente, será apresentado em exemplo de ação desenvolvida para eliminação das causas de acidentes de colisão de comboios em pilares de pontes no rio Tietê.

\subsubsection{Riscos de acidentes}

A Figura 2.4, adaptada de Grabowski (2000), apresenta uma corrente de erros que geram riscos de acidentes com embarcações em uma hidrovia. 


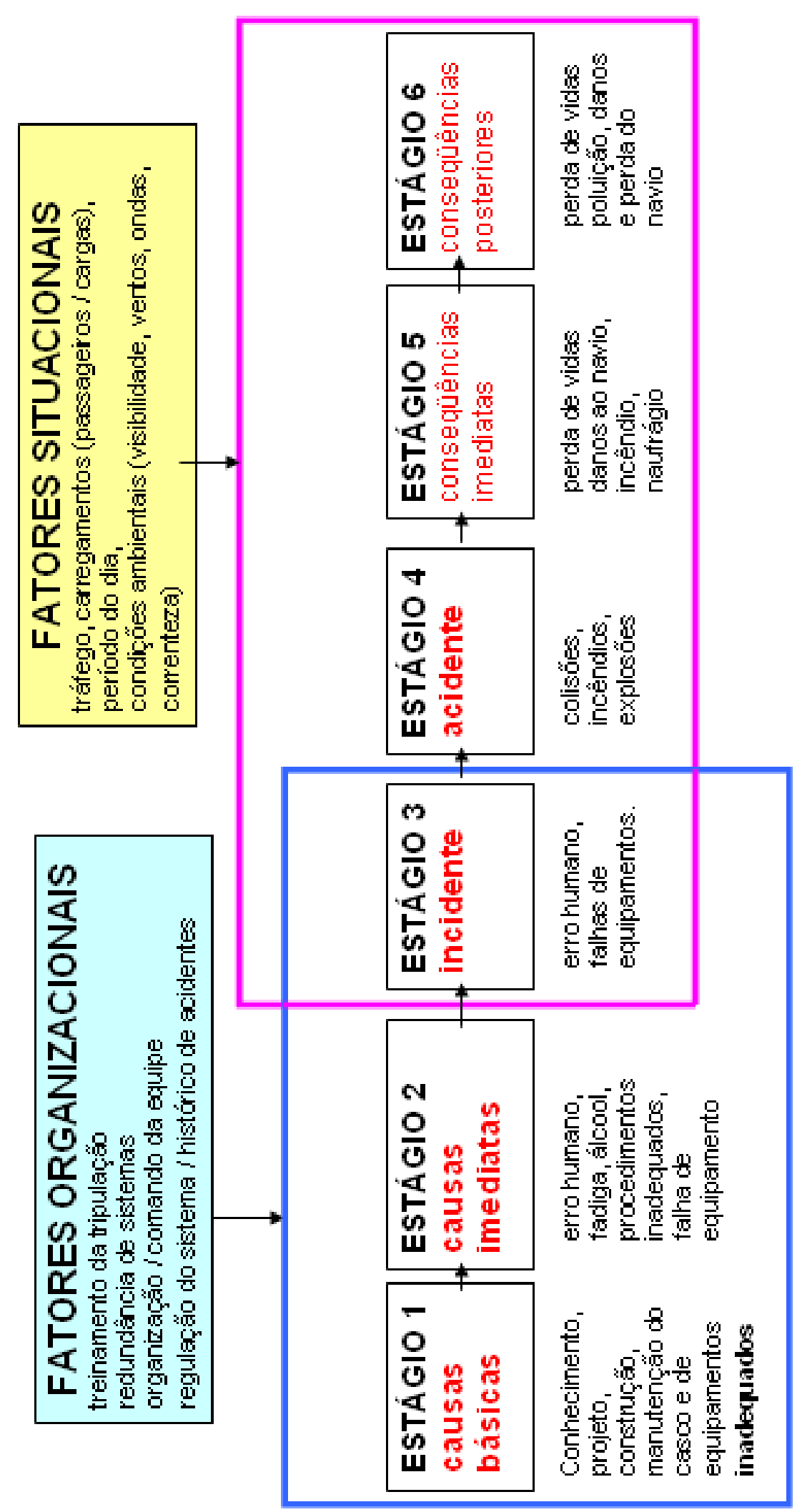

Figura 2.4 - Corrente de riscos de acidentes com embarcações 
Existem causas básicas como projeto, construção e manutenção inadequados assim como despreparo da tripulação, que podem desencadear eventos que levam à ocorrência de acidentes. Há causas imediatas, geralmente ligadas a erros humanos ou falhas de equipamentos que, somadas ou não às causas básicas, também ocasionam acidentes. E assim por diante, há um encadeamento até a verificação das consequiências dos acidentes.

Agem os fatores organizacionais (treinamento da tripulação, regulação do transporte, etc.) e os fatores situacionais (condições ambientais, intensidade de tráfego, etc.) nos estágios indicados na corrente.

Esta visão sequiencial dos estágios e fatores que podem levar à ocorrência de acidentes no sistema de transporte facilita o processo de busca de aumento da segurança da navegação. A eliminação ou a minimização das causas básicas e das causas imediatas deve ser preocupação permanente em todas as etapas que envolvem a vida útil de uma embarcação: concepção, projeto, construção, operação e manutenção.

O acompanhamento do histórico de acidentes com o tipo de embarcação de interesse em hidrovias com características semelhantes àquela em que se pretende operar, permite graduar os riscos de ocorrências de certos tipos de acidentes e antecipadamente eliminar causas básicas. Por exemplo, se em uma hidrovia é comum a ocorrência de choques de embarcações com troncos, uma nova embarcação deve possuir forma de enfrentar tal situação sem riscos de acidentes graves.

\subsubsection{Aspectos de segurança de embarcações fluviais}

Para aumentar a segurança da navegação devem ser identificados os perigos e verificados os níveis correspondentes de riscos de ocorrência de acidentes. $\mathrm{Na}$ seqüência, devem ser estudadas e implantadas formas de controlar os riscos. As várias soluções possíveis para minimização dos riscos deverão ser analisadas à luz da sua efetividade e dos custos envolvidos. 
Um dos problemas técnicos que dificultam o equacionamento adequado dos níveis de riscos em navegação fluvial no Brasil é a falta de levantamentos estatísticos de acidentes com embarcações. Ferreira (2000) apresenta uma primeira análise dos acidentes na hidrovia Tietê-Paraná. A falta de dados de acidentes nas hidrovias brasileiras é explicada por problemas de notificações e de registros, mas, principalmente, pelo fato que ocorrem poucos acidentes com embarcações de carga já que a navegação comercial ainda apresenta volume de tráfego relativamente reduzido.

É possível, entretanto, elaborar uma série de gradação de riscos de acidentes para cada combinação de embarcação com via navegável, a partir das estatísticas de acidentes encontradas em outras hidrovias semelhantes do mundo e baseados nas próprias características físicas da via e da embarcação em questão.

Assim, por exemplo, em um rio com baixas profundidades, é possível levantar a probabilidade de acidentes de encalhes, tendo em vista as características de manobras do comboio, a frequiência de ocorrência de ventos intensos, a sinuosidade de trechos da via, etc.

A Figura 2.5 mostra, a título de exemplo de resultado de análise de dados de acidentes, um registro de acidentes com embarcações de vários portes em trechos considerados de passagem difícil e de passagem fácil (Brolsma et al., 1988). Há maior concentração de acidentes em trechos difíceis com embarcações de menor porte.

Um caso que serve para ilustrar a falta de previsão de riscos de acidentes em hidrovias brasileiras é o acontecido no rio Tietê com colisões de comboios em pontes, mostrado a seguir (item 2.4.3). Apenas quando os acidentes começaram a ocorrer é que foram identificadas as causas básicas que poderiam levar àquele tipo de acidente.

Estatísticas de acidentes ocorridos tanto em navegação marítima como em navegação fluvial, têm mostrado que a maior parte (de 60 a 85\%) das causas está relacionada a erros humanos. Os demais acidentes têm causas mecânicas, condições ambientais adversas, etc. Esta distribuição ressalta a importância da qualidade da formação e da instrução das tripulações das embarcações. Mas, também, mostra a necessidade de 
fornecer, às tripulações, embarcações dotadas de bons sistemas de propulsão e de manobras. Estudos comprovam que embarcações com alto desempenho, principalmente em manobra, apresentam efeito psicológico benéfico para os pilotos.

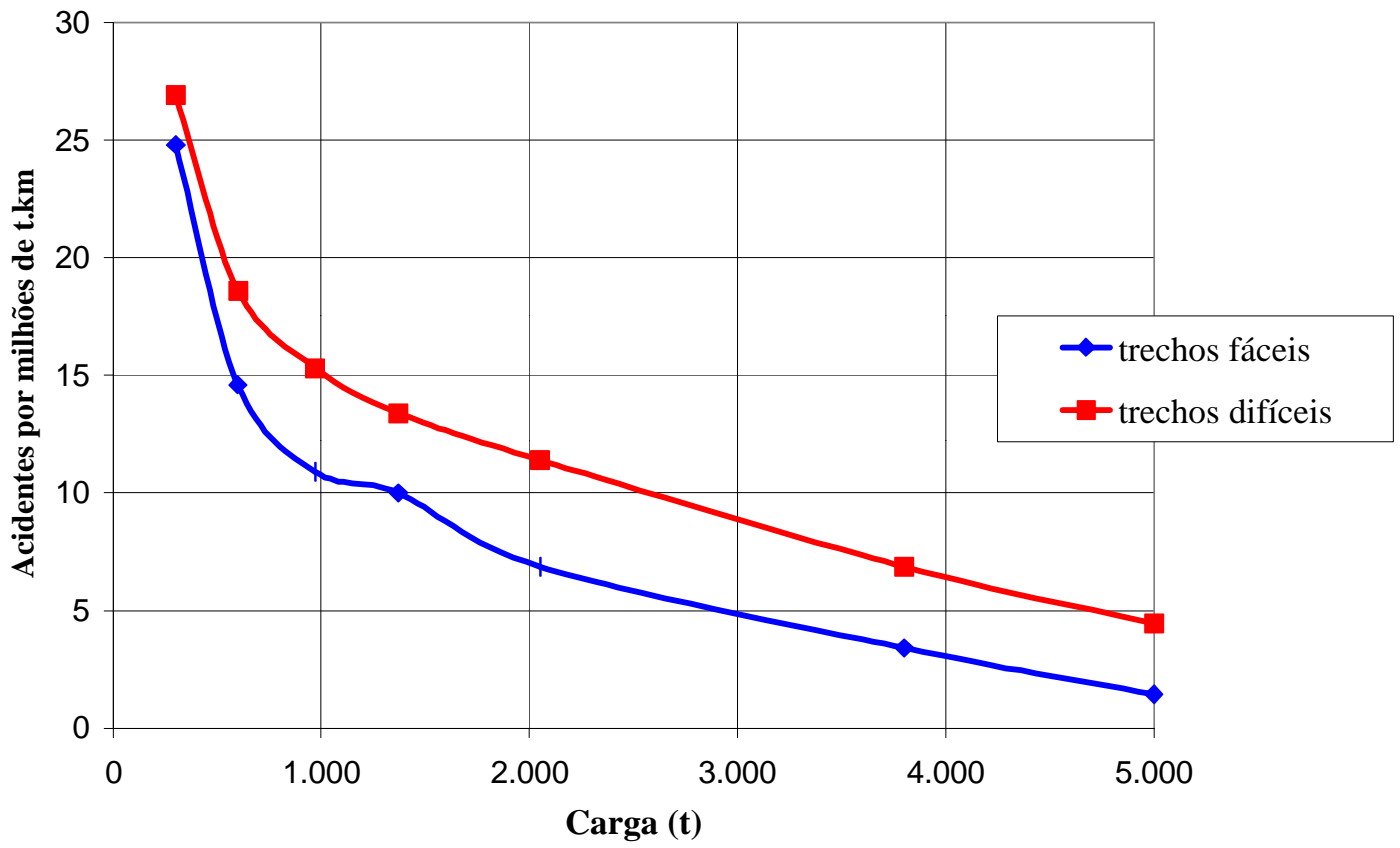

Figura 2.5 - Exemplo de distribuição de acidentes por milhões de t.km em função da dimensão da embarcação e da dificuldade de passagem por determinado trecho do rio (Brolsma et al.,1988)

\subsubsection{Um exemplo de aumento de segurança: passagens sob pontes no rio Tietê}

As características instantâneas de manobras de um comboio fluvial têm uma relação estreita com as suas condições operacionais (calados, formação do comboio, tipos e distribuição de cargas) e ambientais (ventos, ondas, correnteza). Tais características podem ser determinantes para aumentar ou diminuir o risco, sempre presente, de colisões do comboio com pilares de pontes que passam sobre uma hidrovia.

Por outro lado, é imprescindível a instalação de sistemas de proteção dos pilares de pontes que evitem danos maiores às pontes em caso de colisão de embarcações. Um 
acidente em uma ponte pode causar perda de vidas humanas e grandes prejuízos econômicos, e deve ser evitado o máximo possível.

Logo após o início da navegação de grandes comboios no rio Tietê, ocorreu uma série de colisões em pilares de pontes, inclusive com alguns casos de queda de tabuleiro e conseqüente interdição dos tráfegos hidroviário e rodoviário, além do enorme risco de perda de vidas.

Quase todas as pontes tinham vãos relativamente reduzidos, na faixa entre 35 e 40 m, e os comboios, com duas chatas em linha, tinham 138 metros de comprimento por 11 metros de boca.

Na Figura 2.6 estão indicadas as bocas virtuais para quatro formações de comboios: quatro chatas, duas a duas; duas chatas em linha; duas chatas em paralelo; uma chata. A partir do momento em que a embarcação tem um determinado ângulo de deriva, resultante da composição das forças nos lemes e no casco com as forças externas (correntezas, ventos), existe uma boca virtual (soma da boca real com a resultante do ângulo de deriva assumido) que será utilizada na passagem da ponte. Os resultados mostram o grande risco envolvido na passagem de comboios com mais de uma chata em vão de 35 m e com ventos cuja ação leve a um ângulo de deriva alto. Ou seja, apesar das pontes do rio Tietê terem sido construídas obedecendo aos gabaritos oficiais do Ministério dos Transportes, os vãos são muito menores que os necessários para a navegação com segurança de comboios.

Com a ocorrência de acidentes em pontes, foram realizados estudos para a proteção dos pilares. A partir da constatação que grande parte das pontes da hidrovia TietêParaná encontra-se em locais de profundidades relativamente altas, a solução técnica e economicamente mais viável foi a concepção de módulos flutuantes, fabricados em aço, ancorados por poitas de concreto. A fim de absorver a máxima energia possível em caso de colisão de embarcações, o sistema foi concebido com grandes bolinas presas aos cascos, atuando como amortecedores hidrodinâmicos, e com amarras de "nylon", que absorvem energia com sua deformação elástica em caso de tração (Padovezi \& Caltabeloti , 2001). 
No caso em questão, houve um processo de adaptação das embarcações à via forçado pelas circunstâncias. A Capitania Fluvial restringiu, no início de 2000, a passagem sob as pontes a uma única chata em pontes sem proteção de pilares e a duas chatas em pontes cujos sistemas protetores de pilares já se encontravam instalados. Os casos de acidentes em pontes, que cresciam ano a ano, pararam de ocorrer (Figura 2.7), demonstrando, na prática, que era excessivo o número de chatas em comboios que passavam sob as pontes sem sistemas de proteção de pilares no rio Tietê.

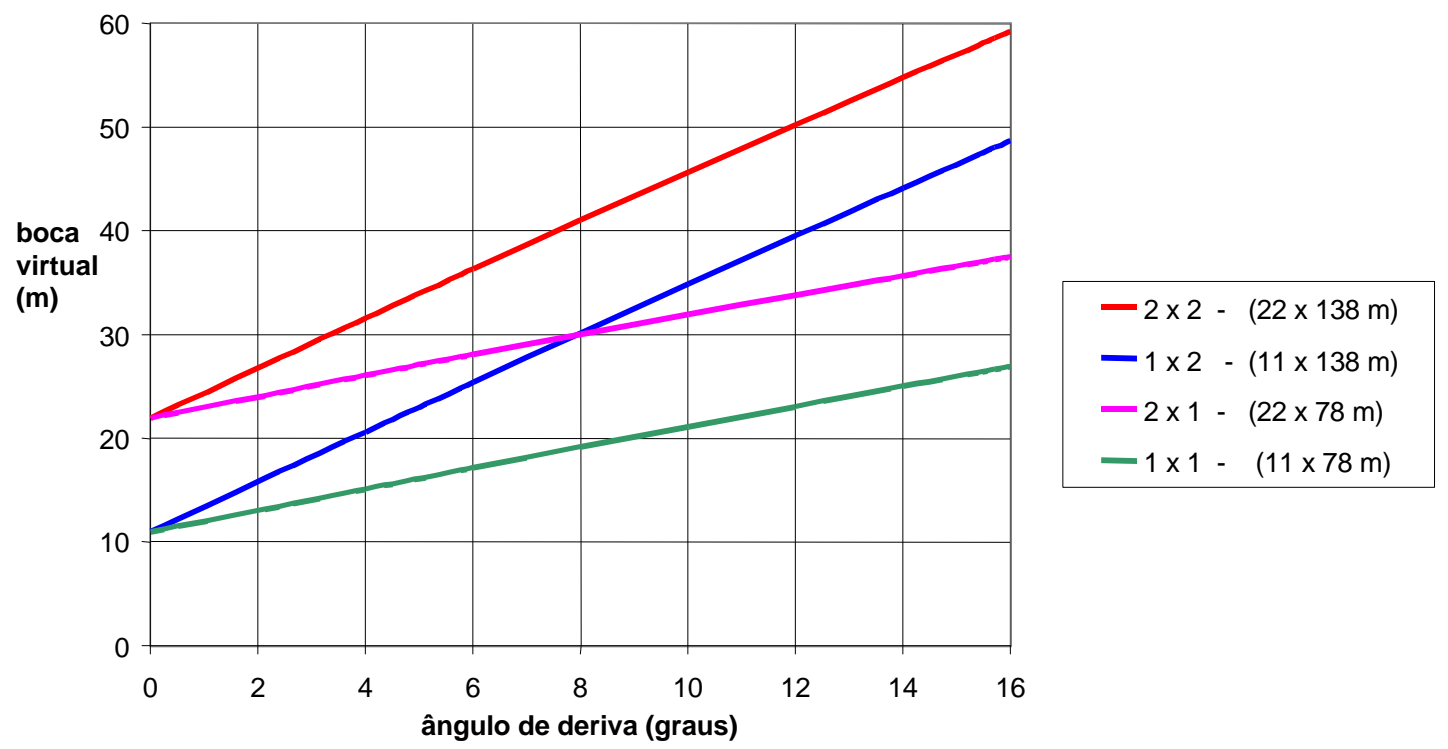

Figura 2.6 - Boca virtual em função do ângulo de deriva e da formação do comboio

A maior parte dos acidentes na passagem sob pontes ocorreu com comboios formados por chatas com deslocamento leve, expostas a ventos de intensidade alta, condição que resulta em graves problemas de manobrabilidade. Como as chatas leves apresentam grande altura de convés a partir do nível d'água (da ordem de 3,2m) há, ainda, um agravante de prejudicar a visibilidade do piloto.

Deve ser lembrado que a passagem sob as pontes do Tietê deve ser feita com cabines de comando (ou passadiços), com controle de altura, abaixadas, para que seja garantida uma altura máxima da embarcação, acima da linha d'água, menor que $7 \mathrm{~m}$. 
Aos poucos, a solução para aumentar de modo definitivo a segurança da passagem de grandes embarcações sob pontes no rio Tietê está sendo implantada: estão sendo duplicados os vãos horizontais das pontes por meio da retirada de um pilar e substituição de dois tabuleiros contíguos em concreto por um único, com o dobro de comprimento, fabricado em aço (de menor peso, quase equivalente ao peso dos dois tabuleiros de concreto). Os pilares do novo vão de navegação certamente receberão sistemas protetores contra colisões de embarcações.

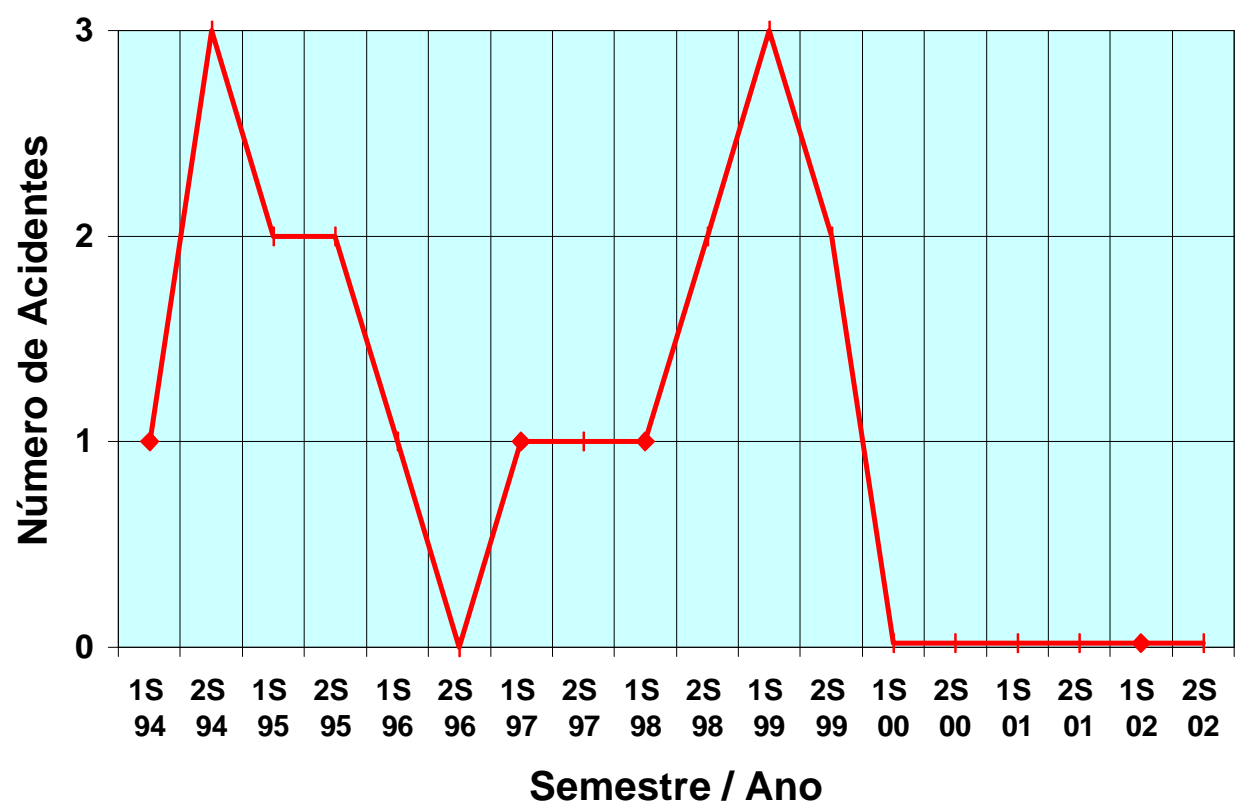

Figura 2.7 - Número de acidentes de comboios em pontes da Hidrovia Tietê-Paraná

Tomando por base a corrente de riscos apresentada no item 2.4.1, as causas básicas de acidentes de comboios em pilares de pontes no rio Tietê poderiam ser assim listadas:

a) vão horizontal de ponte inadequado;

b) baixa manobrabilidade dos comboios na condição leve;

c) grande área lateral exposta a ventos dos comboios na condição leve;

d) falta de treinamento de pilotos;

e) falta de sistema de proteção física de pilares. 
As causas a, d e e têm sido devidamente atacadas. As causas b e c, ligadas às características das embarcações leves, ainda permanecem. A solução técnica mais adequada para estas duas causas pode ser a introdução de um sistema auxiliar de manobras no comboio, como um hélice azimutal ou um "bow thruster" na chata de vante.

\subsection{Integração entre Embarcações e Via Navegável}

A Tabela 2.3 apresenta uma relação das características restritivas de trechos de vias navegáveis com os efeitos e interferências sobre a segurança, meio ambiente e eficiência das embarcações. Na seqüência, a Tabela 2.4 alinha algumas possíveis soluções para os problemas relacionados com cada característica restritiva da via. As indicações presentes nas Tabelas 2.3 e 2.4 são praticamente auto-explicativas. Contudo, alguns pontos merecem uma maior reflexão, que será apresentada a seguir.

2.5.1 Os comboios apresentam uma tendência maior de provocar sucção no fundo do rio que embarcações de menor seção transversal. Também o alto carregamento dos propulsores dos empurradores faz com que o jato de água na saída interfira com o fundo de rios mais rasos. Tal jato de saída dos propulsores pode ser expresso por uma equação simples da teoria linear da quantidade de movimento (Khattab, 1999): $v_{P}=v_{A} \cdot \sqrt{1+\frac{8 \cdot K_{T}}{\pi \cdot J^{2}}}$, sendo: $v_{P}$ a velocidade do jato de saída do propulsor; $\mathrm{v}_{\mathrm{A}}$, a velocidade de avanço; $\mathrm{K}_{\mathrm{T}}$, o coeficiente de empuxo e J, o coeficiente de avanço do hélice. Pela equação, é possível perceber que a velocidade de saída da água será menor se o diâmetro do propulsor for maior e, conseqüentemente, a rotação for menor. Porém, em empurradores fluviais no Brasil, quase sempre com restrições de calados, será praticamente impossível operar com grandes diâmetros de propulsores. 
Tabela 2.3 - Relação das características das vias e seus efeitos e interferências sobre a segurança, meio ambiente e eficiência do transporte por embarcações

\begin{tabular}{|c|c|c|c|}
\hline $\begin{array}{c}\text { característica da } \\
\text { via }\end{array}$ & $\begin{array}{c}\text { efeitos sobre a } \\
\text { segurança da } \\
\text { navegação }\end{array}$ & $\begin{array}{c}\text { efeitos sobre o } \\
\text { ambiente }\end{array}$ & $\begin{array}{c}\text { efeitos sobre a } \\
\text { eficiência do } \\
\text { transporte }\end{array}$ \\
\hline $\begin{array}{l}\text { trechos com águas } \\
\text { rasas }\end{array}$ & $\begin{array}{l}\text { perda de velocidade } \\
\text { e alteração de } \\
\text { manobrabilidade; } \\
\text { choques no fundo }\end{array}$ & $\begin{array}{l}\text { Efeito de sucção de } \\
\text { material do fundo } \\
\text { do rio (suspensão) }\end{array}$ & $\begin{array}{l}\text { perda de } \\
\text { velocidade; maior } \\
\text { consumo de } \\
\text { combustíveis }\end{array}$ \\
\hline trechos estreitos & $\begin{array}{l}\text { choques com } \\
\text { margens }\end{array}$ & $\begin{array}{l}\text { Interferência nas } \\
\text { margens por ondas } \\
\text { da embarcação }\end{array}$ & $\begin{array}{l}\text { restrição de } \\
\text { velocidade }\end{array}$ \\
\hline curvas fechadas & $\begin{array}{l}\text { necessidade de } \\
\text { manobras extras; } \\
\text { choques com } \\
\text { margens }\end{array}$ & $\begin{array}{l}\text { Possibilidade de } \\
\text { choques com } \\
\text { margens }\end{array}$ & $\begin{array}{l}\text { necessidade de } \\
\text { manobras extras, } \\
\text { acréscimo de tempo } \\
\text { de viagem }\end{array}$ \\
\hline $\begin{array}{l}\text { obras de arte } \\
\text { (pontes, eclusas) }\end{array}$ & $\begin{array}{l}\text { Possibilidade de } \\
\text { colisões, inclusive } \\
\text { de grande } \\
\text { periculosidade }\end{array}$ & & $\begin{array}{l}\text { exigência de } \\
\text { manobras precisas, } \\
\text { restrições de alturas } \\
\text { de passadiços } \\
\end{array}$ \\
\hline $\begin{array}{l}\text { condições } \\
\text { ambientais adversas } \\
\text { (ventos, corren- } \\
\text { tezas, neblina) }\end{array}$ & $\begin{array}{l}\text { necessidade de bons } \\
\text { sistemas propul- } \\
\text { sores e de manobras }\end{array}$ & & $\begin{array}{l}\text { maior consumo de } \\
\text { combustíveis; } \\
\text { acréscimo de tempo } \\
\text { de viagem }\end{array}$ \\
\hline $\begin{array}{l}\text { Locais com } \\
\text { formações de ondas }\end{array}$ & \begin{tabular}{|l} 
movimentos \\
excessivos, riscos \\
de rupturas de \\
amarras e \\
instabilidades
\end{tabular} & & $\begin{array}{l}\text { Aumento de } \\
\text { resistência ao } \\
\text { avanço; maior } \\
\text { consumo de } \\
\text { combustíveis }\end{array}$ \\
\hline $\begin{array}{l}\text { troncos e outros } \\
\text { materiais flutuando }\end{array}$ & $\begin{array}{l}\text { probabilidade de } \\
\text { choques no casco, } \\
\text { propulsores e lemes }\end{array}$ & & \\
\hline $\begin{array}{l}\text { trechos com altas } \\
\text { velocidades de } \\
\text { correntes }\end{array}$ & $\begin{array}{l}\text { exigência de sobre- } \\
\text { potência e de poder } \\
\text { de manobra }\end{array}$ & & $\begin{array}{l}\text { maior consumo de } \\
\text { combustíveis }\end{array}$ \\
\hline $\begin{array}{l}\text { Grandes variações } \\
\text { de nível d'água ao } \\
\text { longo do ano }\end{array}$ & & & $\begin{array}{l}\text { Problemas em águas } \\
\text { baixas; restrições } \\
\text { operacionais }\end{array}$ \\
\hline $\begin{array}{l}\text { área de preservação } \\
\text { ambiental }\end{array}$ & & $\begin{array}{l}\text { suspensão de } \\
\text { material do fundo } \\
\text { do rio e ameaça à } \\
\text { estabilidade das } \\
\text { margens; acesso de } \\
\text { pessoas indesejadas } \\
\text { a áreas preservadas }\end{array}$ & $\begin{array}{l}\text { restrição de } \\
\text { paradas, grande } \\
\text { autonomia, } \\
\text { limite de intensidade } \\
\text { de tráfego }\end{array}$ \\
\hline
\end{tabular}


Tabela 2.4 - Relação das possíveis soluções para enfrentamento de problemas de restrições nas vias navegáveis

\begin{tabular}{|c|c|}
\hline Característica da via & Possíveis soluções \\
\hline trechos com águas rasas & $\begin{array}{l}\text { dimensões dos calados; potência suficiente; } \\
\text { desmembramentos de comboios }\end{array}$ \\
\hline trechos estreitos & $\begin{array}{l}\text { obras de proteção física das margens; } \\
\text { restrição de velocidade }\end{array}$ \\
\hline curvas fechadas & $\begin{array}{l}\text { bons sistemas de manobras em velocidades } \\
\text { baixas; restrições de dimensões de comboios; } \\
\text { desmembramentos }\end{array}$ \\
\hline obras de arte (pontes, eclusas) & $\begin{array}{l}\text { bons sistemas de manobras; cabines de } \\
\text { comando retráteis; desmembramentos }\end{array}$ \\
\hline $\begin{array}{l}\text { condições ambientais adversas } \\
\text { (ventos, correntezas, neblina) }\end{array}$ & $\begin{array}{l}\text { sistemas auxiliares de manobras; sistema de } \\
\text { informações sobre condições ambientais; } \\
\text { sistemas de navegação }\end{array}$ \\
\hline Locais com formações de ondas & $\begin{array}{l}\text { Reforços em amarras; estudos de formas de } \\
\text { cascos; sistema de informações sobre estado } \\
\text { de ondas }\end{array}$ \\
\hline troncos flutuando & $\begin{array}{l}\text { propulsores com "ice class"; sistemas } \\
\text { protetores de popas contra choques; linhas de } \\
\text { cascos adequadas }\end{array}$ \\
\hline $\begin{array}{l}\text { trechos com altas velocidades de } \\
\text { correntes }\end{array}$ & $\begin{array}{l}\text { treinamento da tripulação; verificação do } \\
\text { estado de máquinas }\end{array}$ \\
\hline $\begin{array}{l}\text { Grandes variações de nível d'água } \\
\text { ao longo do ano }\end{array}$ & $\begin{array}{l}\text { calado menor do empurrador; carga parcial } \\
\text { das chatas em águas baixas; chatas de } \\
\text { diferentes capacidades }\end{array}$ \\
\hline área de preservação ambiental & $\begin{array}{l}\text { grande autonomia das embarcações; instrução } \\
\text { especial da tripulação; cuidados ambientais } \\
\text { (ruído, emissões, águas servidas, } \\
\text { combustíveis); controle e fiscalização do } \\
\text { tráfego }\end{array}$ \\
\hline
\end{tabular}

2.5.2 As dimensões de chatas utilizadas no Brasil, com comprimentos da ordem de $60 \mathrm{~m}$, têm contribuído para evitar problemas de carregamento excessivo da viga-navio durante a operação em regiões com ondas. Também deve ser 
ressaltado que não são muito freqüentes situações de navegação em ondas: mesmo em locais com pistas favoráveis à formação de ondas, é necessária a existência de ventos de altas intensidades durante tempos relativamente longos. Por outro lado, as amarras entre chatas, e entre chatas e empurrador, são extremamente solicitadas em navegação em ondas, requerendo dimensionamento apropriado.

2.5.3 Em hidrovias que possuem trechos com pequenas profundidades (a maior parte das hidrovias do Brasil), os cascos devem ser dimensionados para suportar esforços decorrentes de encalhes, posto que a probabilidade de ocorrência deste tipo de acidente é alta.

2.5.4 Propulsores com “ice-class" são aqueles cujas espessuras de pás são determinadas segundo regras para hélices de navios quebra-gelo, que apresentam alta frequiência de choques. A vantagem é que há um reforço na estrutura das pás para que possam suportar choques de determinada magnitude sem sofrer rupturas.

2.5.5 Não foi incluído o lastreamento de chatas como solução para aumento da segurança de navegação em condições de ventos, ondas, etc. É relativamente comum nas hidrovias brasileiras a operação de comboios com chatas vazias, porque muitas cargas hidroviárias têm mão única. Ocorre, por exemplo, no transporte hidroviário de produtos agrícolas ou minerais em comboios especializados em granéis sólidos, onde quase sempre não existem cargas de retorno. Chatas vazias tendem a piorar a segurança da navegação dos comboios em condições ambientais adversas e em trechos em ondas, assim como em passagens críticas. Uma possível solução seria a utilização de lastros nas chatas sem cargas, à semelhança do que ocorre com embarcações marítimas. O lastreamento aumentaria a manobrabilidade do comboio, diminuiria a área exposta ao vento lateral e diminuiria a intensidade dos movimentos das embarcações em ondas. Contudo, os efeitos do lastreamento seriam negativos tanto no aspecto ambiental (pelo descarte de águas de outras regiões) como na complicação das operações de cargas, descargas e limpezas 
de tanques. As chatas fluviais não têm preparo especial para recebimento de lastro e a adoção de tanques especiais levaria a perdas de capacidade de transporte com diminuição de carga útil.

2.5.6 Uma alternativa ao lastreamento de todas as chatas, seria uma solução indicada por Koster (1975) e que poderia ser melhor estudada no futuro: lastrar apenas uma chata posicionada à vante do comboio. Tal providência diminui as desvantagens do lastreamento porque o volume de lastro utilizado em cada viagem é sensivelmente menor e apresenta, segundo Koster, aumento da manobrabilidade e melhora do ângulo de visada.

\subsection{Custos Externos}

Invariavelmente, quando se formulam justificativas para realização de obras de infraestrutura ou mesmo para implantação de uma determinada hidrovia, surgem comparações entre os custos de transportes dos vários modais existentes. Acontece que, quando se busca uma visão sistêmica, abrangente, do transporte no País, passa a não fazer sentido a simples comparação direta de valores de custos de fretes entre diferentes modais.

Devem, no entendimento do autor, ser acrescentados os chamados custos externos nos vários custos das modalidades de transporte. Mesmo que não seja, logicamente, para aplicá-los diretamente sobre os preços de fretes, mas, pelo menos, para deixar claro quais os custos reais globais, ou seja, a soma dos custos para o cliente do transporte com os custos para a sociedade como um todo.

Por exemplo, um sistema hidroviário que, por sua operação, possa tirar centenas de caminhões de determinados trechos congestionados de vias rodoviárias, diminuindo tempos de viagens, reduzindo gastos de combustíveis e, conseqüentemente, minimizando a poluição, além de reduzir a probabilidade de ocorrência de acidentes, deve receber incentivos, de forma a manter-se como uma alternativa viável de transporte. $\mathrm{O}$ incentivo pode vir em forma de construção de terminais intermodais e na facilitação da integração logística. 
Quando não são computados ganhos sócio-ambientais, há risco de não se avaliar corretamente o modal de transporte. Determinada forma de transporte de certas cargas pode ser lucrativa para os transportadores, mas, se não for bem equacionada, pode tornar-se prejudicial à sociedade como um todo. As perdas causadas por maiores consumos de combustível, por aumento de risco de acidentes, por influência negativa no trânsito em determinados trechos de vias públicas, tendem a transferir recursos da população para os transportadores.

Beuthe et al. (2002) apresenta um estudo dos seguintes custos externos (ou sociais): congestionamentos, poluição, acidentes, ruído, desgastes e quebras. Além disso, relaciona o consumo de energia de cada modal. A Tabela 2.5 mostra o resultado de uma simulação feita para o transporte de cargas de longo curso na Bélgica em um ano, por três modais.

Tabela 2.5 - Custos externos totais anuais com internalização de custos (Beuthe et al., 2002)

\begin{tabular}{|l|c|c|c|}
\cline { 2 - 4 } \multicolumn{1}{c|}{ Custos externos } & \multicolumn{3}{c|}{ Custo externo (milhões de euros) } \\
\hline congestionamentos & rodoviário & aquaviário & ferroviário \\
\hline poluição & 412,8 & - & - \\
\hline acidentes & 419,7 & 88,2 & 51,9 \\
\hline ruído & 298,6 & - & 25,1 \\
\hline desgastes das vias & 153,3 & - & 32,0 \\
\hline total & 46,4 & - & - \\
\hline porcentagem do total & $1.330,8$ & 88,2 & 109,0 \\
\hline consumo de energia (milhões de joules) & $9,0 \times 10^{10}$ & $3,5 \times 10^{9}$ & $6,1 \times 10^{9}$ \\
\hline
\end{tabular}




\section{APLICAÇÃO DO CONCEITO DE EMBARCAÇÕES ADAPTADAS À VIA}

Uma vez conhecida a complexa relação entre o desempenho de embarcações com cada uma das características importantes da via navegável, e assumindo a importância de ampliar o enfoque de projeto de embarcações fluviais de cargas, adicionando, ao objetivo de obter os mínimos custos de transporte, verificações quanto aos níveis de segurança e de interferência ambiental, pode ser desenvolvido um modelo que auxilie o projetista a projetar as embarcações mais adequadas para operar em determinada hidrovia.

O presente Capítulo mostra as premissas e os passos do desenvolvimento de um modelo para projeto de comboios fluviais adaptados à via.

\subsection{Definição do Problema}

O transporte de cargas por um comboio de chatas ao longo de uma determinada hidrovia será bem sucedido, analisando de uma maneira global, quando for eficiente, seguro e com pequena interferência no meio ambiente. A eficiência resulta em lucros para o sistema de transporte de bens, garantindo a necessária continuidade dos serviços. A segurança evita que custos altos e possíveis consequiências inaceitáveis à sociedade possam ser imputados ao sistema de transporte. Uma menor interferência ambiental faz com que os custos sociais decorrentes da utilização de rios como vias de transporte sejam os menores possíveis, principalmente quando comparados aos custos sociais de outros modais de transportes. 
O transporte hidroviário brasileiro encontra-se em um estágio de desenvolvimento que requer uma ampliação e uma aglutinação racional dos modelos de análise e de projetos de embarcações, com o objetivo de identificar as embarcações cujos projetos e procedimentos operacionais são os mais adaptados a uma hidrovia com determinadas características. Embarcações adaptadas à hidrovia são definidas aqui como aquelas mais eficientes economicamente e que atendem a critérios específicos de segurança da navegação e de níveis de interferência ambiental.

Neste sentido, é desenvolvida, no presente estudo, uma proposta de procedimentos de projeto de comboios fluviais adaptados a uma hidrovia, que integre racionalmente os três fatores considerados importantes para uma visão ampla do sistema de transporte de cargas no Brasil: eficiência, segurança e respeito ao meio ambiente. Este modelo deve ser utilizado para identificar a melhor embarcação para transporte de cargas em uma determinada hidrovia. Adicionalmente, o procedimento define o esquema operacional do comboio (velocidade, calado, e eventuais desmembramentos) para os diversos trechos do percurso.

Para a obtenção da eficiência do transporte, são utilizados cálculos de desempenho do sistema de propulsão e de manobras em cada trecho específico de uma hidrovia, incluindo os trechos críticos como passagens sob pontes e por eclusas, e, finalmente, cálculos de custos do transporte. Os modelos utilizados nestes cálculos são baseados em formulações e procedimentos do atual estágio de desenvolvimento técnico das respectivas áreas. Os modelos foram validados a partir de resultados de ensaios com modelos em escala reduzida e em escala real, no caso de propulsão de comboios fluviais, e a partir de comparações com dados publicados ou coletados, no caso de custos de transporte.

Para a obtenção de uma estimativa do nível de risco de ocorrência de acidentes, existente em cada situação da navegação de comboios por uma hidrovia, foi elaborado um modelo de risco, que integra a estimativa de freqüência de ocorrência (ou probabilidade) com a conseqüência esperada. O modelo foi desenvolvido utilizando dados estatísticos relativos a comboios fluviais de várias hidrovias do mundo, posto que não há um número suficiente de registros de acidentes de comboios 
nas hidrovias brasileiras. A forma de desenvolvimento do modelo, contudo, permite a atualização, com facilidade, das bases de dados adotadas, tão logo estejam disponíveis dados específicos de acidentes de comboios em cada hidrovia brasileira. A adoção de dados de acidentes de outras hidrovias do mundo é tecnicamente aceitável se forem separadas as influências de cada fator de risco (visibilidade, ventos, largura da via, profundidade, etc.) sobre os dados utilizados. Outra questão importante é que a maior utilidade do modelo de riscos será servir de base de comparação entre alternativas de soluções na relação via-comboios, e não para estimar, com precisão absoluta, a probabilidade de ocorrência de acidentes.

O modelo de verificação da existência de interferências ambientais, devidas à passagem de comboios, é relativamente simplificado, mas com utilidade para avaliação de efeitos de passagens de comboios em trechos com restrições de largura e de profundidade. São estimados os efeitos da passagem do comboio sobre as margens, que estejam próximas, e sobre o fundo o rio, em trechos mais rasos. A possível desestabilização de margens e a possibilidade de aumentar a turbidez da água, com a manutenção da suspensão de sedimentos em trechos rasos com maior volume de tráfego, são objeto do modelo que, ao final, poderá indicar limites de velocidades e de freqüências de passagens de comboio a fim de minimizar os efeitos sobre o ambiente. Também são calculadas as quantidades de emissões de gases pelos motores durante as viagens, como um alerta ao problema de poluição do ar, que pode ser considerado relativamente reduzido no caso de embarcações fluviais, desde que não haja uma grande concentração de operações de comboios em um mesmo trecho. Os modelos para cálculos de ondas geradas por comboios e de jatos dos propulsores são baseados em formulações da teoria de escoamento, com algumas adaptações realizadas a partir de resultados experimentais publicados em referências bibliográficas. Uma outra questão importante, de como enquadrar a relação viacomboios nas hidrovias que passam por áreas de preservação ambiental, também é tratada, com ênfase nos cuidados especiais que devem ser observados nestas áreas. 


\subsection{Alternativas de Solução}

Durante a fase de projeto ou durante a operação de comboios fluviais, várias decisões técnicas importantes devem ser tomadas. Várias alternativas de soluções devem ser analisadas para que o conjunto de decisões leve a uma embarcação mais eficiente, mais segura e com pequena interferência ambiental. Para a obtenção do comboio fluvial mais adaptado a uma determinada hidrovia, verificando os três fatores-objetivo (eficiência, segurança e meio ambiente), serão analisadas as seguintes alternativas de solução:

A. formação dos comboios - decisão sobre dimensões, quantidades e disposição de chatas em comboios; pode haver necessidade de desmembramentos do conjunto de chatas durante uma viagem;

B. escolha de calados de operação - definição do calado máximo de operação, em função das restrições de profundidades em alguns trechos da via e possibilidade de decisão de adotar a alternativa de não lastreamento, trafegando com chatas vazias, o que pode elevar os riscos de acidentes;

C. margem de potência instalada no empurrador - esta decisão está ligada à segurança da navegação já que uma sobre-potência pode ser requerida em situações de emergência (paradas bruscas, tempestades, etc.);

D. qualidade de manobras do comboio - a adoção de soluções de maior manobrabilidade pode permitir o enfrentamento das restrições da via, com reflexos na melhoria da segurança da navegação;

E. velocidades de operação - nem sempre as velocidades adequadas são as velocidades máximas; há velocidades econômicas de operação e há, às vezes, necessidade de redução de velocidade em trechos críticos, para não elevar os riscos de acidentes e nem o nível de interferência com as margens e com o fundo do rio. 


\subsection{Definição de Critérios de Seleção}

A seleção das melhores alternativas de projeto e operação de um comboio fluvial de cargas, será feita pela comparação de resultados de desempenho econômico, ou seja, deverão ser escolhidas as alternativas que apresentem o menor custo de transporte, desde que sejam atendidos os limites aceitáveis de níveis de risco para a segurança da navegação e para a interferência ambiental.

\subsubsection{Avaliação da Eficiência ou Desempenho Econômico}

O critério de avaliação do desempenho econômico será o mínimo custo de transporte por tonelada quilômetro. $\mathrm{O}$ custo é obtido para uma viagem em profundidades médias anuais da hidrovia, e, depois, é extrapolado para um período de um ano. O custo é influenciado por diversos parâmetros, entre eles, as potências gastas e as velocidades desenvolvidas pelo comboio, as quais são influenciadas pelas características detalhadas da hidrovia e do comboio, assim como por condições ambientais e procedimentos operacionais.

\subsubsection{Avaliação da Segurança da Navegação}

A segurança da navegação é avaliada por meio de um modelo de risco baseado em análises estatísticas dos incidentes e dos acidentes que ocorreram com embarcações do tipo em estudo e em hidrovias com características semelhantes àquelas que se deseja estudar. A estimativa de riscos de ocorrência de acidentes de um comboio, em cada trecho da via, possibilita a comparação com limites aceitáveis determinados para cada tipo de acidente. Os tipos de acidentes que são levados em consideração no modelo de risco são aqueles considerados mais freqüentes, ou com possibilidade de se tornarem freqüentes, nas hidrovias brasileiras: encalhes, choques com fundo rochoso, choques entre embarcações, colisões em pontes ou em outras estruturas da via, choques com troncos e choques com margens. As estimativas de riscos têm o objetivo de avaliar as alternativas de soluções de projetos e identificar aquelas que apresentam níveis de risco acima do desejável. Estes níveis de risco de referência, para cada tipo 
de acidente, são determinados com base em estatísticas de acidentes em hidrovias do mundo. Uma vez detectado um problema de segurança, podem ser sugeridas formas de resolvê-lo para que determinada alternativa seja adotada. Por exemplo, se um comboio tem dimensões que elevam o risco de acidentes em determinada passagem crítica da via (ponte, canal ou trecho em curvas), o modelo indica que devem ocorrer desmembramentos do comboio e soma os custos e os tempos deste procedimento aos custos e tempos totais do transporte.

\subsubsection{Avaliação da Interferência Ambiental Direta}

A interferência ambiental direta da passagem de comboios em determinado rio é sempre verificada, em dois aspectos mais importantes: possibilidade de desestabilização de margens por ação de ondas geradas por passagens de comboios, e turbulência e aumento da turbidez da água por efeitos da passagem de comboios (sucção e jato dos propulsores). Se alguma das alternativas de soluções em estudo resultar em problemas de ordem ambiental, o modelo é capaz de indicar a solução. Por exemplo, pode assumir uma redução da velocidade de passagem do comboio por determinado trecho estreito e raso, a fim de minimizar as interferências com margens e fundo do rio.

\subsection{Avaliação das Alternativas e Escolha}

As comparações entre os resultados econômicos das várias alternativas de projeto e de operação de comboios, que já passaram pelos critérios definidos de segurança e interferência ambiental, permitem que seja identificada a embarcação mais eficiente para uma hidrovia.

Os custos obtidos de transporte com a embarcação mais eficiente deverão ser comparados com os valores de fretes atualmente praticados pelos modais hidroviário, ferroviário e rodoviário para o transporte de cargas. 


\subsection{Seleção da Melhor Alternativa}

A melhor alternativa de embarcação, resultante da análise de seu projeto e de sua operação, será aquela com melhor desempenho econômico, ou seja, de mínimo custo de transporte, dentre todas aquelas alternativas que respondem a contento às preocupações com os três fatores-objetivo.

\subsection{Elaboração do Modelo}

A elaboração do modelo teve o objetivo de prover meios técnicos para possibilitar a escolha das melhores alternativas de projeto e operação de um comboio fluvial de cargas, dentro da visão ampliada de necessidade de obtenção de menores custos de transporte com níveis adequados de segurança e de respeito ao meio ambiente.

Foi desenvolvida, portanto, uma maneira de integrar os vários fatores que influenciam a relação entre via e comboios, para que, de uma forma racional, possam ser analisados os seus efeitos sobre o desempenho de uma embarcação integrada à via.

A análise comparativa das implicações da relação via-comboio indicará, ao final, as melhores soluções para as alternativas de projeto e operação de um comboio, que deve proporcionar um transporte por custos mínimos, atendendo a certos requisitos de segurança de navegação e de interferência ambiental.

\subsubsection{Descrição do Modelo}

O modelo foi desenvolvido com a seguinte concepção:

- para facilitar a escolha das melhores alternativas de projeto, houve necessidade de simular um comboio navegando em uma hidrovia e, em cada trecho diferenciado desta, calcular o desempenho da embarcação;

- assim, são determinadas as velocidades de cruzeiro, os tempos de viagem e as potências utilizadas dos motores, em cada trecho da viagem, o que permite determinar os custos envolvidos de uma forma relativamente detalhada; 
- a simulação da relação via-comboio, para tornar-se mais abrangente, levou em consideração todas as restrições pontuais importantes da via (pontes, canais, eclusas, curvas) e a probabilidade de ocorrência de condições ambientais adversas (ventos, ondas, neblinas);

- como a solução final deve atender a requisitos de segurança da navegação, foi elaborado um modelo de risco, que, em cada situação da viagem do comboio pela via, avalie o nível de probabilidade de ocorrência de acidentes;

- o modelo pode adotar solução para contornar problema de médio ou alto nível de risco de acidente como, por exemplo, assumir um certo número de desmembramentos do comboio em algumas passagens críticas;

- os níveis de interferência ambiental provocada pela passagem do comboio por trechos mais suscetíveis da via (geralmente com restrições de largura e de profundidade) também são estimados;

- pode ser assumida, por exemplo, uma redução de velocidade do comboio, em uma passagem crítica, ou por problema de interferência ambiental (possibilidade de instabilidade de margens, por exemplo), ou por questão de segurança (riscos de choques com o fundo do canal, por exemplo);

- todos os custos e tempos adicionais de viagens resultantes de condições ambientais adversas, incorporadas como fenômenos estocásticos, ou de soluções indicadas, por critério de segurança ou de interferência ambiental, para passagens em trechos críticos, são somados aos custos totais da viagem do comboio;

- os custos totais serão comparados aos custos totais obtidos para as demais alternativas de solução.

\subsubsection{A Busca de Soluções}

As alternativas de projeto, escolhidas no item 3.2, serão, a seguir, detalhadas, para um melhor entendimento de como será utilizado o modelo para avaliação de cada alternativa de solução que deve levar ao comboio mais eficiente, seguro e pouco poluente. 
As alternativas serão sempre verificadas quanto à sua viabilidade econômica. $\mathrm{O}$ projeto básico é feito para os trechos sem grandes restrições da via e, em seguida, são feitas verificações, nos trechos com maiores restrições, dos possíveis problemas relacionados com a segurança da navegação e com o meio ambiente. Tais problemas podem gerar alterações para minimização dos seus efeitos, como desmembramentos do comboio, redução da velocidade de passagem nos locais de restrições, alterações de calados, etc.

\subsubsection{Dimensões e formação do comboio}

Em uma boa parte, a capacidade de transporte do comboio em uma viagem é determinada pelas suas dimensões. E tais dimensões estão diretamente ligadas às restrições existentes na hidrovia. Eclusas, trechos com limitação de profundidade, curvas fechadas e trechos estreitos têm influência direta sobre a determinação das maiores dimensões possíveis de um comboio. Uma concepção, atualmente utilizada na hidrovia Tietê-Paraná, é determinar a dimensão final do comboio para trafegar nos trechos sem restrições, que representam, naquela hidrovia, a maior extensão, e utilizar o expediente de desmembrar o conjunto de chatas para passar em trechos críticos de restrições. O modelo faz a verificação da necessidade de desmembramentos para passagens em eclusas, pontes e canais fechados, e computa os tempos e custos associados a tais atividades. No caso de eclusas, a restrição para as dimensões do comboio, é física, dada pelas dimensões das câmaras. Para as demais passagens críticas, o modelo leva em consideração os níveis de risco e de interferência ambiental para a determinação da maior formação de comboio que deve passar pelos locais.

Com relação às dimensões de cada chata, há uma tendência de adoção, nas várias hidrovias do mundo, de medidas em certas faixas restritas. Grandes comboios com chatas de comprimentos reduzidos tendem a possuir quantidade maior de peso de aço e, portanto, necessitam maior investimento inicial. Um maior número de chatas de menor comprimento levará a maiores valores de potências despendidas porque há um aumento de resistência hidrodinâmica no grande número de junções (descontinuidades) entre as chatas. Por outro lado, grandes comprimentos exigem projetos estruturais especiais, aumentando os custos de construção. Assim, na prática, 
os comprimentos de chatas têm variado na faixa entre 40 e 80 metros, e as bocas têm variado entre 8 e 16 metros. Em hidrovias com barragens, tanto o comprimento como a largura das chatas devem ser escolhidos para otimizar o aproveitamento do espaço das câmaras das eclusas. O modelo pode, se for necessário, avaliar as alternativas de dimensionamento de chatas, adotando, para tal, relações entre dimensões principais compiladas em Hirata et al. (1992).

\subsubsection{Calados de operação}

O calado de operação de um comboio fluvial é escolhido, geralmente, por motivos econômicos, para se transportar a maior quantidade possível de cargas em uma viagem. Ou seja, há uma tendência de utilização do maior calado possível em uma hidrovia. Ocorre que as restrições de profundidades das hidrovias são variáveis ao longo do tempo e a escolha do maior calado possível em época de águas cheias pode fazer com que as chatas naveguem a maior parte do tempo com carga parcial. Há, portanto, a possibilidade do maior custo de investimento em chatas de maiores calados e de maiores pesos não ser compensado pela utilização de calados menores ao longo do ano. Esta avaliação está incluída no modelo desenvolvido, por meio da variação sistemática de combinações de calados de operação e de pontais das chatas, em que o cômputo de custos de investimento e custos operacionais deve mostrar, ao final, qual a melhor alternativa de calado do comboio, do ponto de vista econômico. A definição do calado de projeto para uma determinada hidrovia terá, certamente, influência na decisão da potência instalada no empurrador.

O calado máximo do comboio será avaliado em relação aos aspectos de segurança e de interferência ambiental nos trechos com restrições de profundidade da via. A verificação da possibilidade de choques dos cascos no fundo do rio é feita pelo cálculo do afundamento paralelo ("squat") que ocorre em águas rasas. Em se constatando a possibilidade de choques no fundo, pode ser diminuída a velocidade de passagem do comboio para minimizar o problema. Se, mesmo com a redução de velocidade, ainda o nível de risco de acidente for alto, deverá ser sugerida a diminuição do calado escolhido. Os riscos de ocorrência de encalhes e de choques no fundo do rio serão estimados em função das profundidades e dos calados. Os níveis 
de interferência ambiental também serão verificados nestes trechos mais críticos. $\mathrm{O}$ modelo é capaz de propor alterações necessárias nos calados, em combinação com a velocidade de passagem do comboio, para satisfazer aos requisitos de segurança e de interferência ambiental.

Outra questão importante relativa ao calado do comboio, é a navegação com chatas vazias, muito freqüente em transporte de cargas a granel, onde geralmente há dificuldades para obtenção de cargas de retorno. Chatas vazias resultam em operação com menor manobrabilidade do comboio e uma maior exposição à ação de ventos. Neste caso, se o empurrador não é dotado de sistemas mais eficientes de manobra, como propulsores azimutais ou lemes de alta sustentação combinados com sistema auxiliar de manobra, os riscos de ocorrência de acidentes são maiores do que com comboios carregados. Em hidrovias em que ocorrem ventos de intensidade alta durante um grande número de dias por ano, esta condição será verificada pela comparação entre as forças devidas ao vento no comboio e a capacidade do sistema de manobras compensar aqueles esforços. Se o sistema de manobras for insuficiente para compensar as forças resultantes de ventos, várias alternativas podem ser examinadas: lastreamento das chatas, melhoria do sistema de manobras, não transitar durante os períodos de ventos muito intensos. O lastreamento, por razões econômicas e de ordem ambiental, deve ser evitado o máximo possível. A solução de parar o comboio em períodos de ventos fortes tende a ser viável apenas quando a quantidade total destas paradas não for significativa ao longo do ano. A solução mais indicada, porque apresenta benefícios para todas as condições de operação, seria a melhoria do sistema de manobra do comboio.

\subsubsection{Potência instalada no empurrador}

A definição da margem de potência instalada no empurrador, que pode ser definida como a potência extra disponível para utilização em situações de emergência, está diretamente ligada à segurança da navegação. Uma potência extra adequada pode diminuir riscos de colisões de embarcações, à medida que proporciona melhores desempenhos em parada brusca (Khattab, 1999). Também aumenta a segurança no 
sentido que pode contribuir para compensar os efeitos de forças externas como ventos, ondas e correnteza, principalmente em situações críticas, como em tempestades.

O modelo adota, como critérios para verificar se a potência instalada em um empurrador é suficiente para a segurança do comboio, dois procedimentos:

- verificação da relação entre a potência instalada no empurrador e o deslocamento do comboio e comparações com dados coletados nas várias hidrovias do mundo; se a relação potência/deslocamento estiver abaixo dos valores mínimos da base de dados utilizada, será emitido um aviso sobre o problema, assim como serão aumentados os níveis de risco de acidentes;

- estimativa da distância de parada brusca do comboio, nas suas várias condições operacionais, e comparação com o valor de distância máxima segura de parada, definido como sendo de três vezes o comprimento total do comboio; se o valor de referência for excedido, serão emitidos avisos e também serão aumentados os níveis de risco de acidentes.

\subsubsection{Qualidade de manobras do comboio}

A manobrabilidade do comboio é muito importante tanto para a segurança da navegação como para o desempenho econômico do transporte.

Com relação à segurança, equipamentos de manobras adequados compensam os efeitos de forças externas existentes (ondas, ventos, correntes) permitindo controle eficiente do rumo. Melhores respostas da embarcação ao governo contribuem para a redução do risco de acidentes.

Um comboio com boa manobrabilidade pode diminuir a necessidade de desmembramentos em determinadas regiões críticas da via, reduzindo tempos de viagens e, conseqüentemente, custos.

Os equipamentos de manobras têm uma influência direta sobre a manobrabilidade do comboio e devem, por isto, ser analisados de forma cuidadosa, ponderando os custos 
de instalação e de manutenção com os benefícios operacionais. Existem sistemas como os propulsores "cicloidais" (do tipo Voith-Schneider), que apresentam ótimo rendimento, mas representam custos praticamente impeditivos. Os sistemas de propulsores e lemes convencionais são os mais utilizados em todo o mundo porque apresentam os menores custos de instalação e de manutenção, apesar de um desempenho em manobras pouco satisfatório para as necessidades de comboios fluviais. Uma outra solução é a adoção de hélices azimutais (“Z drive”) que resultam em ótimo desempenho em manobras, têm um custo intermediário entre o sistema convencional e os propulsores "cicloidais", mas apresentam algumas desvantagens como alto custo de manutenção e perdas maiores em transmissão de potência. Finalmente, existe a possibilidade de utilização de lemes de alta sustentação, como lemes com "flaps", que podem representar um ganho de qualidade com relação ao sistema convencional, sem grandes custos de instalação e de manutenção. Todas as opções de sistemas de manobras podem ser combinadas com sistemas auxiliares como impelidores laterais ("bow thrusters"), lemes de proa e lemes de flanco.

O modelo estima, de uma forma aproximada, os custos e a influência sobre os níveis de risco de acidentes das seguintes opções de sistemas:

a) sistema convencional de hélices e de lemes, com ou sem lemes de flanco;

b) sistema convencional dotado de um sistema auxiliar de manobra (impelidores laterais ou lemes de proa);

c) propulsores azimutais;

d) lemes de alta sustentação, em lugar dos lemes convencionais de singradura;

e) lemes de alta sustentação, combinado com um sistema auxiliar (impelidores laterais ou lemes de proa);

\subsubsection{Velocidades de operação}

As velocidades de operação do comboio em uma hidrovia têm ligação com a potência disponível dos motores, com os custos operacionais, já que o consumo de combustível é proporcional ao cubo da velocidade, e, em trechos mais críticos da via, com a segurança e com os níveis de interferência ambiental. 
O modelo permite a análise dos custos resultantes de várias opções de velocidades médias de operação, com conseqüentes alterações de valores de potências instaladas no empurrador. Tomando como referência os requisitos de segurança e de meio ambiente, o modelo calcula as velocidades máximas de passagem do comboio por vários trechos com restrições de largura e de profundidade, assim com em trechos com curvas fechadas. Se as velocidades máximas em trechos críticos forem menores que as velocidades de cruzeiro, o modelo adotará aquelas velocidades, para que sejam reduzidos riscos de acidentes e de problemas de interferência com as margens e com o fundo do rio.

\subsubsection{Resumo das Verificações das Alternativas de Projeto}

A Tabela 3.1 mostra as verificações de desempenho, que o modelo pode realizar nos cinco grupos de alternativas de projeto, com relação a cada um dos três fatoresobjetivo: eficiência, segurança e ambiente.

Tabela 3.1 - Verificações das alternativas de projeto em função dos fatores-objetivo do modelo proposto

\begin{tabular}{|l|l|l|l|}
\hline \multirow{2}{*}{ alternativas } & \multicolumn{3}{|c|}{ Fator - Objetivo } \\
\cline { 2 - 4 } & \multicolumn{1}{|c|}{ sefiência } & \multicolumn{1}{|c|}{ segurança } & \multicolumn{1}{c|}{ ambiente } \\
\hline $\begin{array}{l}\text { Dimensões e } \\
\text { formação do } \\
\text { comboio }\end{array}$ & $\begin{array}{l}\text { Capacidade de carga } \\
\text { por peso em aço } \\
\text { Potência requerida } \\
\text { Dimensões x Custos }\end{array}$ & $\begin{array}{l}\text { Nível de Risco em } \\
\text { passagens críticas } \\
\text { Desmembramentos }\end{array}$ & $\begin{array}{l}\text { Efeitos sobre } \\
\text { margens e fundos } \\
\text { em trechos rasos } \\
\text { e estreitos }\end{array}$ \\
\hline $\begin{array}{l}\text { Calados de } \\
\text { operação }\end{array}$ & $\begin{array}{l}\text { Capacidade de carga } \\
\text { Restrições da via } \\
\text { Chatas vazias }\end{array}$ & $\begin{array}{l}\text { Nível de Risco em } \\
\text { trechos rasos } \\
\text { Restrições de calado } \\
\text { Riscos com chatas vazias }\end{array}$ & $\begin{array}{l}\text { Efeitos sobre } \\
\text { margens e fundos } \\
\text { em trechos rasos } \\
\text { e estreitos }\end{array}$ \\
\hline $\begin{array}{l}\text { Margem de } \\
\text { potência }\end{array}$ & $\begin{array}{l}\text { Potência x Custos } \\
\text { Potência média de } \\
\text { operação }\end{array}$ & $\begin{array}{l}\text { Requisito de parada } \\
\text { brusca } \\
\text { Manobras em emergência }\end{array}$ & $\begin{array}{l}\text { Potência x } \\
\text { emissões }\end{array}$ \\
\hline $\begin{array}{l}\text { Qualidade de } \\
\text { manobra }\end{array}$ & $\begin{array}{l}\text { Diminuição de tempos } \\
\text { (desmembramentos, } \\
\text { manutenção de rumo) }\end{array}$ & $\begin{array}{l}\text { Diminuição de riscos / } \\
\text { comparações de sistemas }\end{array}$ & $\begin{array}{l}\text { Diminuição de } \\
\text { riscos / } \\
\text { comparações }\end{array}$ \\
\hline $\begin{array}{l}\text { Velocidades de } \\
\text { operação }\end{array}$ & $\begin{array}{l}\text { Velocidade x Custos } \\
\text { Potência requerida }\end{array}$ & $\begin{array}{l}\text { Restrições de } \\
\text { velocidades em trechos } \\
\text { críticos }\end{array}$ & $\begin{array}{l}\text { Restrições de } \\
\text { velocidades em } \\
\text { trechos críticos }\end{array}$ \\
\hline
\end{tabular}


Os fatores segurança e ambiente podem gerar restrições que implicam em alterações de custos, influindo no fator eficiência. Um exemplo típico seria a necessidade de determinado número de desmembramentos do comboio, aumentando o nível de segurança em trechos críticos, mas acrescendo custos à alternativa de formação de comboio que estaria em análise.

\subsection{Considerações Especiais}

\subsubsection{Amarras do Conjunto de Chatas e Empurrador}

O modelo assume que as amarras entre chatas, e entre chatas e empurrador, de um comboio, são firmemente presas, de forma a compor um conjunto semi-rígido com restrição horizontal de movimentos e com possibilidade de movimentos relativos verticais (com amplitude máxima da ordem de 10 centímetros) entre as partes.

\subsubsection{Volume de Tráfego}

Tanto com relação aos custos do transporte como aos riscos de acidentes e à interferência ambiental, é importante que não existam concentrações de tráfego de embarcações.

Muitas embarcações navegando em um mesmo trecho da via podem provocar:

- filas em eclusas, em canais estreitos ou em outros pontos críticos como passagens sob pontes de vãos reduzidos,

- maior probabilidade de ocorrência de colisões entre embarcações, particularmente quando há mais fatores de risco presentes, como falta de visibilidade, curvas fechadas, ventos ou correntes de través, etc.;

- maior concentração de emissões de gases de descarga dos motores dos empurradores; 
- manutenção da turbidez da água em trechos rasos, porque a frequiência de passagem de comboios prejudicará a sedimentação dos materiais sólidos que são levantados pela passagem de embarcações; a turbidez por longo período de tempo prejudica as espécies vivas que habitam o rio (Garcia, 2001).

Em princípio, o modelo assumirá que os comboios estarão espalhados ao longo da hidrovia, sendo evitadas, pelas razões já expostas, quaisquer concentrações de embarcações. $\mathrm{O}$ volume esperado de tráfego de comboios nas hidrovias brasileiras nos próximos anos não é tão grande a ponto de ser necessária a convivência com os problemas de concentrações de embarcações.

Para evitar concentrações de embarcações em um mesmo trecho, será adequado que haja um planejamento das seqüências de viagens dos comboios de todos as companhias de transporte que operam em uma hidrovia.

\subsubsection{Variações de Níveis D’Água ao Longo do Ano}

A variação do nível d'água nas várias hidrovias ao longo de um ano é um dado que não pode ser esquecido por qualquer modelo. Tal variação é mais acentuada nos rios em corrente livre e mais suave nos rios chamados de "regularizados", que têm reservatórios devido a barragens. Nos rios das regiões centro-oeste e norte, as variações anuais são mais acentuadas do que nos rios das regiões sul e sudeste.

A fim de levar em consideração a variação de nível d'água nos rios em estudo, é sugerido o seguinte procedimento:

i) obter o desempenho do comboio em condições de profundidades, de correnteza e de larguras da via consideradas como médias anuais, de modo que os resultados de eficiência reflitam o desempenho médio anual do comboio;

ii) obter o desempenho para a condição de águas baixas (menores profundidades), com o objetivo de melhor avaliar as questões relacionadas com a segurança da navegação e com interferências ambientais. 


\section{DETALHAMENTO DO MODELO ELABORADO}

O modelo para avaliação técnica e econômica da viagem de um comboio pela via foi desenvolvido sob a forma de módulos, um para cada um dos fatores considerados importantes na relação via-comboio. A separação dos temas em módulos permite um bom entendimento e uma visualização ampla do modelo, assim como possibilita que sejam introduzidas, no futuro, atualizações de bases de dados ou alguma revisão que venha a ser considerada pertinente.

A seguir, são detalhados os conteúdos dos módulos que compõem o modelo proposto.

\subsection{Módulo Propulsão}

\subsubsection{Estimativas de resistências ao avanço de comboios fluviais}

Os valores de potências efetivas do casco $\mathrm{P}_{\mathrm{E}}$ são obtidos, em função da velocidade real V, pela utilização da formulação de Howe (Christopoulos \& Latorre, 1983) para comboios fluviais, adaptada para utilização de valores em unidades métricas:

$P_{E}=0,14426 \cdot F \cdot e^{\frac{0,445}{\left(h-T_{C}\right)}} \cdot\left(\frac{T_{C}}{0,3048}\right)^{0,6+\frac{15,24}{\left(W-B_{C}\right)}} \cdot L_{C}^{0,38} \cdot B_{C}^{1,19} \cdot V^{3}$ 
em que $T_{C}, L_{C}$ e $B_{C}$ representam, respectivamente, o calado médio, o comprimento total e a boca total do comboio de chatas; h é a profundidade média local, W é a largura média e $\mathrm{V}$ é a velocidade do comboio em $\mathrm{m} / \mathrm{s}$.

A formulação de Howe já embute correções tanto para restrição lateral como para profundidade reduzida.

A formulação de Howe apresenta um fator $\mathrm{F}$ geralmente associado ao grau de integração do conjunto de chatas de um comboio. $\mathrm{O}$ valor original proposto por Howe foi 0,07289 (Latorre, 1985); vários outros foram sugeridos por Toutant (apud Latorre, 1985), após uma série de ensaios com modelos de comboios.

Os valores do fator F da formulação de Howe, utilizados pelo modelo, foram obtidos comparando-se, para cada formação do comboio, as curvas de estimativas de $\mathrm{P}_{\mathrm{E}}$ com os resultados dos ensaios de resistência à propulsão dos modelos em escala 1:13 do Comboio Araguaia (IPT, 1993; Padovezi, 1997), com outros resultados de ensaios de modelos comboios no Tanque de Provas do IPT (IPT, 1970) e com alguns resultados publicados (Bilen \& Bilen-Katic, 1997; Luthra, 1978). Os valores adotados de F no modelo são apresentados na Tabela 4.1. O ANEXO B mostra os dados utilizados para obtenção dos valores de F.

A formulação de Howe não é aplicável para comboios trafegando com chatas vazias, como verificado com comparações com resultados experimentais. As condições com chatas vazias, geralmente com calados na faixa entre 0,4 e $0,7 \mathrm{~m}$, mostram grande influência dos empurradores no cômputo da resistência ao avanço do comboio, já que estes apresentam calados na faixa entre 1,8 e 2,5 m. Para a condição de chatas vazias, é sugerido estimar a potência efetiva do casco com a seguinte formulação, obtida por regressão de resultados experimentais com chatas vazias (ANEXO B):

$$
\mathrm{P}_{\mathrm{E}}=\mathrm{P}_{\mathrm{E}} \text { (howe) }+1,83 * \mathrm{~V}^{3}, \quad \text { para } \mathrm{T}_{\mathrm{C}}<0,80 \mathrm{~m},
$$

onde $\mathrm{P}_{\mathrm{E}}$ (howe) é a potência efetiva, em $\mathrm{kW}$, obtida pela formulação de Howe e $\mathrm{V}$ é a velocidade do comboio em $\mathrm{m} / \mathrm{s}$. 
Tabela 4.1 - Valores do fator $\mathbf{F}$ da formulação de Howe, adotados no modelo

\begin{tabular}{|l|c|}
\hline \multicolumn{1}{|c|}{ Formação do comboio } & F \\
\hline Uma chata (1 linha, 1 coluna) & 0,040 \\
\hline Duas chatas em linha (1 linha, 2 colunas) & 0,050 \\
\hline Duas chatas em paralelo (2 linhas, 1 coluna) & 0,043 \\
\hline Três chatas em linha (1 linha, 3 colunas) & 0,040 \\
\hline Quatro chatas (2 linhas, 2 colunas) & 0,045 \\
\hline Seis chatas (2 linhas, 3 colunas) & 0,058 \\
\hline Seis chatas (3 linhas, 2 colunas) & 0,070 \\
\hline Outras formações de chatas & 0,070 \\
\hline
\end{tabular}

\subsubsection{Estimativas de coeficientes propulsivos de comboios fluviais}

Verhey (1983) indicou, para comboios fluviais, valores de coeficientes de esteira entre 0,30 e 0,45. Binek e Müller (1978) obtiveram, em ensaios com modelos em profundidade restrita, valores para bi-hélices e tri-hélices. IPT (1970) apresenta uma extensa série de ensaios em escala reduzida de modelos de comboios com diferentes formações, com levantamentos dos coeficientes propulsivos em águas profundas.

No modelo, as estimativas de coeficientes de esteira efetiva, de redução da força propulsora e de eficiência relativa rotativa são feitas em função da formação do comboio e da profundidade, a partir da utilização dos dados de várias referências (IPT, 1970; IPT, 1993-a; Basin \& Miniovich, 1963; Luthra, 1979; Luthra, 1974; Binek \& Müller, 1978).

Com relação ao efeito da presença de lemes de flanco na popa de um empurrador, instalados à frente dos hélices, Luthra (1979) apresentou resultados experimentais que indicaram um acréscimo de 3 a 5\% na potência utilizada devido à presença de lemes de flanco. Padovezi (1997) verificou um acréscimo em potência, devido a lemes de 
flancos, de 4\% nas medições realizadas com o Comboio de Pesquisas do Araguaia. O acréscimo de potência utilizada, em uma dada velocidade à vante, pela presença de lemes de flanco, é explicado pela diminuição da eficiência do casco, resultante de interferências destes lemes no escoamento na região de entrada dos hélices. Assim, quando há lemes de flanco, o modelo assume que há um decréscimo de 4\% na eficiência do casco e, por conseguinte, na eficiência propulsiva e na potência necessária:

$\left(\eta_{\mathrm{h}}\right.$ com lemes de flanco $)=\left(\eta_{\mathrm{h}}\right.$ sem lemes de flanco $) / 1,04$,

onde $\eta_{\mathrm{h}}$ é a eficiência do casco, definida como $\eta_{\mathrm{h}}=(1-\mathrm{t}) /(1-\omega)$.

\subsubsection{Curvas de água aberta dos hélices dos empurradores}

Os hélices adotados para os cálculos de desempenho propulsivo e em manobras (neste caso, no módulo manobras) são de duas séries sistemáticas consideradas representativas do conjunto dos hélices de comboios fluviais (Padovezi, 1997):

- série B-Troost, que abrange a maior faixa de variações geométricas dos hélices convencionais; os coeficientes das curvas de ensaios em água aberta dos hélices da série B-Troost foram obtidos em Lewis (1988);

- série Kaplan, que apresenta os hélices em dutos mais conhecidos e utilizados; os coeficientes das curvas de ensaios em água aberta dos hélices da série Kaplan foram obtidos em Lewis (1987) e em Gent \& Oosterveld (1983).

\subsubsection{Verificação de presença de cavitação excessiva}

O módulo propulsão faz uma verificação da possibilidade de queda de empuxo, por cavitação excessiva nas pás dos hélices do empurrador do comboio. Se houver uma situação em que ocorre queda de empuxo, o modelo emitirá um aviso sobre o 
problema relativo à propulsão e diminuirá o número de rotações dos hélices (com decremento de 0,10 rps) até o problema desaparecer.

A equação que indica a condição de início de queda de empuxo em hélices foi obtida a partir do Diagrama de Burril (Padovezi, 1997). O coeficiente de carregamento relativo às pressões presentes nas pás $\tau_{\mathrm{C}}$ é relacionado com o índice de cavitação, definido a partir da velocidade resultante na seção a $r / R=0,70$ das pás, $\sigma_{0,7 R}$. Assim, há queda de empuxo quando:

$\tau_{C} \geq 0,70 \cdot\left(\sigma_{0,7 R}\right)$, onde:

$$
\begin{gathered}
\tau_{C}=\frac{T}{\frac{1}{2} \cdot \rho \cdot V_{R}^{2} \cdot A_{P}} \\
\sigma_{0,7 R}=\frac{P_{o}-P_{V}}{\frac{1}{2} \cdot \rho \cdot V_{R}^{2}} \\
V_{R}=\sqrt{V_{A}^{2}+(0,7 \cdot \pi \cdot n \cdot D)^{2}}
\end{gathered}
$$

onde: $\mathrm{P}_{\mathrm{O}}$ é a pressão estática referida ao centro do eixo do hélice, $\mathrm{P}_{\mathrm{V}}$ é a pressão de vaporização da água, $\mathrm{V}_{\mathrm{A}}$ é a velocidade de avanço, $\mathrm{P}$ é o passo do hélice, $\mathrm{A}_{\mathrm{E}}$ é a área expandida do hélice, $\mathrm{D}$ é o diâmetro do hélice, $\mathrm{A}_{\mathrm{P}}$ é a área projetada das pás e $\mathrm{n}$ é o número de rotações do hélice.

\subsubsection{Estimativas de desempenho propulsivo}

Com os dados calculados de resistência ao avanço, em função da velocidade do comboio, dos coeficientes propulsivos e das curvas de ensaios em água aberta dos propulsores, e contando ainda com os dados de motores e reversores, são obtidos os pontos de operação do sistema casco-hélices-motores em cada trecho da hidrovia.

Para cada trecho, tanto do trajeto de ida como do de volta, é obtida uma curva de potência efetiva $\mathrm{P}_{\mathrm{E}}$ em função da velocidade real V, utilizando a formulação de Howe. Por meio da igualdade do coeficiente de empuxo calculado com os dados do casco e o coeficiente de empuxo dos ensaios de água aberta dos hélices, são determinados os 
pontos de operação e os resultados de rotações e potências dos motores e velocidade da embarcação. Têm-se, assim, as curvas de operação do comboio em cada trecho específico da via.

A partir das curvas obtidas, o ponto de operação do conjunto casco-hélice(s)motor(es), em cada trecho da via, é determinado pela seguinte sequiência de critérios:

i) Assumindo que, entre $85 \%$ e $100 \%$ da rotação nominal do motor, a curva de potência máxima contínua (MCR) pode ser obtida considerando o torque $\mathrm{Q}_{\mathrm{m}}$ constante, este valor é igualado ao torque absorvido pelo hélice. Para determinar esta igualdade, levando em consideração o que ocorre na operação real do comboio, pode ser utilizada uma margem de potência. Este valor de margem indicará quanto, da potência máxima contínua disponível, será utilizada pela embarcação.

$Q_{m}=\frac{M C R \cdot e t \cdot m \arg e m}{2 \cdot \pi \cdot n_{\text {nom }}}$, onde MCR é a potência máxima contínua do motor na rotação nominal $\mathrm{n}_{\text {nom. }}$. Para igualar os valores de torques, ainda é utilizada a relação $Q_{m}=\frac{Q}{\text { red }}$, sendo red a relação de redução de rotações da caixa reversora.

ii) Se a igualdade de torques levar a valores de rotações dos motores menores ou iguais à rotação máxima nominal $\mathrm{n}_{\text {nom }}$, então este ponto será o de operação do comboio no trecho da via em questão. Contudo, se o número de rotações obtido for maior que $\mathrm{n}_{\text {nom}}$, então este será assumido como sendo o de operação, sendo determinados os valores correspondentes de potências e de velocidade.

iii) É sempre feita uma verificação da possibilidade de ocorrência de queda de empuxo por cavitação excessiva no ponto determinado como de operação do hélice. Se houver queda de empuxo, o número de rotações será reduzido até que o problema desapareça. Este número de rotações passará, neste caso, a determinar o ponto de operação do conjunto casco-hélice(s)-motor(es). Se 
houver redução de rotações por conta de queda de empuxo, será emitida uma mensagem de aviso ao usuário para que seja revisto o projeto dos hélices da embarcação.

iv) À velocidade da embarcação, relativa à água, V, é adicionada a velocidade de corrente média local Vc para a obtenção da velocidade referida à terra, Vreal, da seguinte forma:

comboio descendo o rio (a favor da correnteza): Vreal $=\mathrm{V}+\mathrm{Vc}$;

comboio subindo o rio (contra a correnteza): Vreal $=\mathrm{V}-\mathrm{Vc}$.

Todo o procedimento é repetido para cada trecho da hidrovia, na ida e na volta, determinando cada ponto de operação do comboio. Os dados de velocidades, de rotações e de potências serão utilizados pelo módulo custos, para calcular os tempos e os custos relativos a cada trecho da viagem.

\subsubsection{Sistemas de propulsão não convencionais}

No Brasil, a grande maioria dos empurradores possui hélices abertos, sem dutos, acompanhando, inclusive, uma tendência apresentada nos comboios americanos.

Maynord (2000- b) cita que cerca de 92\% dos empurradores americanos de até 2.350 $\mathrm{kW}$ de potência instalada (faixa em que se incluem quase todos os empurradores brasileiros) têm hélices abertos e apenas $8 \%$ têm hélices em dutos. A opção por hélices sem dutos geralmente é feita em vias onde há riscos de choques das pás com objetos flutuando, a fim de evitar que pedaços de paus se prendam na região entre as pontas das pás e a parede interna dos dutos, travando os eixos dos propulsores (Jukola \& Lindborg, 1999; Padovezi, 1994).

Nos últimos tempos, principalmente na Europa, e no Brasil na Hidrovia do Madeira (Jukola \& Lindborg, 1999), têm sido utilizados propulsores azimutais, com ou sem dutos. Automotores das hidrovias do Sul do Brasil, particularmente da Lagoa dos Patos, utilizam propulsores azimutais desde o final da década de 70. Os propulsores azimutais proporcionam, como sua principal vantagem, ganhos em qualidade de 
manobra e apresentam, como desvantagens, um custo inicial maior que sistemas convencionais e um alto custo de manutenção. O custo de manutenção alto é o maior limitante da utilização deste tipo de propulsão. Em rios onde ocorrem choques de objetos com embarcações, se estas são dotadas de sistemas convencionais, os problemas tendem a se limitar às avarias dos hélices colididos; no caso de propulsores azimutais, as conseqüências dos choques são mais graves, podendo avariar os hélices e parte do conjunto de engrenagens do dispositivo de transmissão.

A caracterização dos propulsores no modelo é feita, inicialmente, pela escolha de uma das duas séries sistemáticas disponíveis (B-Troost e Kaplan) e pela indicação do tipo de propulsores (abertos ou livres, em dutos, azimutais ou mistos). Também deverá ser fornecida a eficiência de transmissão do sistema. No caso de propulsores azimutais, a eficiência de transmissão mecânica é de aproximadamente $90 \%$, enquanto que os sistemas convencionais de eixos em empurradores têm eficiência de transmissão de 95\% (Bilen \& Zerjal, 1999). Há casos em que os propulsores azimutais são movidos por motores hidráulicos (Bilen \& Zerjal, 1999), o que resulta em eficiência de transmissão de cerca de $75 \%$.

Os coeficientes propulsivos $\boldsymbol{\omega}$ e $\mathbf{t}$ tendem a ter valores um pouco menores com propulsores azimutais, quando comparados com propulsores convencionais, devido à simplificação do arranjo da popa dos empurradores, pela ausência de lemes e de estruturas de suportes de eixos, etc.

O modelo adotará os seguintes valores de custos de investimento e de manutenção dos hélices azimutais: $70 \%$ a mais de custo inicial e 100\% a mais de custo de manutenção, comparados com os sistemas de hélices e lemes convencionais. Estas porcentagens, se não são exatas, refletem a tendência relativa entre os custos dos sistemas.

\subsection{Módulo Manobras}

Dentro dos objetivos do presente trabalho, o módulo manobras deve ser capaz de avaliar qual a efetividade de determinado dispositivo de manobra. Sistemas principais ou auxiliares de manobras têm uma série de resultados experimentais com comboios 
fluviais: lemes convencionais, lemes de alta sustentação, lemes de flanco e propulsores azimutais podem ser utilizados nos empurradores, enquanto que lemes de proa e impelidores laterais ("bow thrusters") são, geralmente, instalados em chatas postadas à vante do comboio.

Os comboios fluviais são muito exigidos em manobras, dadas as características de sinuosidade das rotas de navegação e os pontos considerados críticos às manobras, como entradas de eclusas, passagens sob pontes com vãos estreitos e trechos com largura e profundidade reduzidas. Os comboios devem apresentam certas qualidades mínimas de manobras, para manter o rumo certo mesmo sob a ação de forças externas, como ventos, correntes ou ondas.

O módulo manobras fornecerá as características médias de respostas dos sistemas de manobras a partir de suas descrições. Haverá, então, possibilidade de se comparar os desempenhos de vários sistemas e classificar a qualidade de manobras de cada comboio. As estimativas de respostas dos sistemas serão baseadas em dados experimentais, obtidos em ensaios com modelos em escala reduzida e com ensaios em escala real.

\subsubsection{Sistemas de Manobras}

Os seguintes sistemas de manobras são avaliados no módulo manobras:

a) sistema convencional de hélices e de lemes, com ou sem lemes de flanco;

b) propulsores azimutais;

c) lemes de alta sustentação, em lugar dos lemes convencionais de singradura.

A Tabela 4.2 apresenta as características básicas para comparações das vantagens e desvantagens dos três sistemas, baseadas em referências bibliográficas (Bilen \& Zerjal, 1999; Insel \& Helvacioglu, 1996) e informações obtidas pelo autor com fabricantes e usuários dos sistemas. Os valores indicados na Tabela 4.2 são referidos ao sistema convencional de lemes e hélices (todos valores fixados em 100) e devem ser entendidos como uma aproximação preliminar com vistas a comparações entre os sistemas. Principalmente com relação a custos, as relações entre sistemas são dinâmicas. Por exemplo, apenas recentemente foi iniciada a fabricação de lemes de 
alta sustentação no Brasil (mais precisamente, os "flapped rudders"), o que tem diminuído sensivelmente os custos de instalação. Ainda não há notícias de empurradores brasileiros com tais lemes, mas eles apresentam uma boa relação entre custo e benefício, o que levou à sua inclusão como opção de sistema de manobras de comboios.

Também são avaliados os sistemas auxiliares de manobras (impelidores laterais e lemes de proa) que, combinados com um dos sistemas incrementam a qualidade de manobras das embarcações.

Os lemes de flanco apresentam grande auxílio quando os hélices operam à ré, mas apresentam inconvenientes, já referidos no módulo propulsão, de diminuir a eficiência propulsiva quando os hélices operam à vante (ou seja, na quase totalidade do tempo de operação do comboio). Atualmente, há uma tendência de se utilizar sistemas como impelidores laterais em substituição aos lemes de flanco.

Tabela 4.2 - Comparações entre propriedades e características de sistemas de manobras (adotando valor 100 para os sistemas convencionais de lemes e hélices)

\begin{tabular}{|l|c|c|c|}
\hline \multirow{2}{*}{} & \multicolumn{3}{|c|}{ Sistemas de manobras } \\
\cline { 2 - 4 } & $\begin{array}{c}\text { Sistema } \\
\text { convencional }\end{array}$ & $\begin{array}{c}\text { Propulsores } \\
\text { azimutais }\end{array}$ & $\begin{array}{c}\text { Lemes de alta } \\
\text { sustentação }\end{array}$ \\
\hline Eficiência de transmissão & 100 & 95 & 100 \\
\hline Requisito de potência & 100 & 115 & 100 \\
\hline Custo inicial & 100 & 170 & 130 \\
\hline Custo de reparos & 100 & 200 & 110 \\
\hline Desempenho em manobras & 100 & 160 & 150 \\
\hline Desempenho em parada brusca & 100 & 140 & 100 \\
\hline
\end{tabular}

\subsubsection{Parada brusca}

Várias regras existentes indicam que a distância máxima de parada de um comboio fluvial deve ser da ordem de três vezes o comprimento do comboio (UN, 1999), a fim 
de poder evitar colisões com objetos, estruturas na via ou com outras embarcações. Para se ter uma idéia da diferença com navios de grande porte, navios petroleiros têm requisitos de parada em cerca de quinze comprimentos.

A capacidade de parada brusca da embarcação está ligada à potência instalada e às características dos seus hélices, principalmente das suas eficiências operando a ré em baixas velocidades.

Lover (1969) mostra que a parada de uma embarcação se dá em três estágios, às vezes sobrepostos: a fase inicial, em que um tempo é decorrido até haver reversão do sentido de rotação dos hélices de vante para ré; a segunda fase, onde ocorre a perda rápida de velocidade devido à resistência do casco e ao empuxo dos hélices para ré; e a fase final, onde as velocidades são muito baixas e praticamente só atuam os empuxos dos hélices. Na fase final, a força de frenagem dada pelos hélices acionados à ré, supondo-se constantes os efeitos de interação casco-hélices, pode ser aproximada por:

$$
F_{f}=k \cdot\left(\frac{P_{B} \cdot D}{K_{Q}}\right)^{\frac{2}{3}} \cdot K_{T},
$$

onde $\mathrm{k}$ é uma constante; $\mathrm{P}_{\mathrm{B}}$ é a potência disponível dos motores; $\mathrm{K}_{\mathrm{Q}}$ é o coeficiente de torque na condição de tração estática ("bollard-pull”) à ré; $\mathrm{K}_{\mathrm{T}}$ é o coeficiente de empuxo na condição de "bollard-pull" a ré, e D é o diâmetro dos hélices. A formulação indica que quanto maior a potência instalada no empurrador e maior a eficiência dos hélices à ré (razão entre $\mathrm{K}_{\mathrm{T}}$ e $\mathrm{K}_{\mathrm{Q}}$ ), maior será a força de frenagem. Assim, propulsores mais eficientes à ré, como hélices em dutos e propulsores azimutais, proporcionarão maior segurança em caso de necessidade de parada brusca. E empurradores com maiores potências instaladas disponíveis também apresentarão melhores desempenhos.

As estimativas de paradas bruscas terão, portanto, dois objetivos: avaliar a potência instalada no empurrador com relação à resposta da embarcação e comparar 
desempenhos de diferentes sistemas de propulsão e manobras diante de situações de emergência.

Uma forma de estimar a distância percorrida em parada brusca (Harvald, 1976; IMO, 2002) pode ser aplicada, assumindo o seguinte:

- a resistência do casco é proporcional ao quadrado da velocidade da embarcação;

○ o empuxo à ré dos hélices é mantido constante, durante todo o período de reversão dos motores, ao empuxo à ré em velocidade zero (“bollard pull”);

○ a reversão das rotações dos hélices é feita de imediato.

Em uma embarcação, tem-se:

$T \cdot(1-t c)=F+R$, onde T é o empuxo dos hélices, tc é o coeficiente de redução da força propulsora, $\mathrm{R}$ é a resistência ao avanço e $\mathrm{F}$ é a força externa, como a seguir:

$F=m \cdot a=m \frac{d V}{d t}=m \cdot \frac{d V}{d s} \cdot \frac{d s}{d t}=m \cdot \frac{d V}{d s} \cdot V$

$d t=m \cdot \frac{d V}{F} \quad$ e $\quad t=\Delta \cdot(1+k) \cdot \int_{V_{1}}^{0} \frac{1}{F} \cdot d V$

$d s=m \cdot \frac{V}{F} \cdot d V \quad$ e $\quad s=\Delta \cdot(1+k) \cdot \int_{V_{1}}^{0} \frac{V}{F} \cdot d V$

onde m é a massa total, $\Delta$ é o deslocamento da embarcação, $\mathrm{V}$ é a velocidade, $\mathrm{k}$ é um fator devido à massa adicional, a é a aceleração, s é a distância percorrida e t é o tempo. A solução pode ser dada por:

$s=A \cdot \log _{n}(1+B)+C$, onde $A=\frac{\Delta \cdot(1+k)}{2 \cdot K_{O}} ; \quad B=\left(\frac{V_{O}}{U_{O}}\right)^{2} ; \quad C=V_{O} \cdot t r$, sendo 
$K_{O}=\frac{R_{O}}{V_{O}^{2}} ; \quad U_{O}=\frac{T \cdot(1-t c)}{K_{O}} ; \quad$ tr é o tempo de reversão dos motores; $\mathrm{V}_{\mathrm{O}}$ é a velocidade no instante do acionamento da emergência e $R_{O}$ é a resistência ao avanço neste instante.

A utilização destas equações na análise dos resultados de ensaios de parada brusca realizados com comboios em escala $1: 6$ (Hirata, 2000) e em escala real (IPT, 1998) mostrou uma correlação satisfatória (Figura 4.1), o que permitiu que o modelo adotasse estas equações para estimar a distância de parada brusca de comboios.

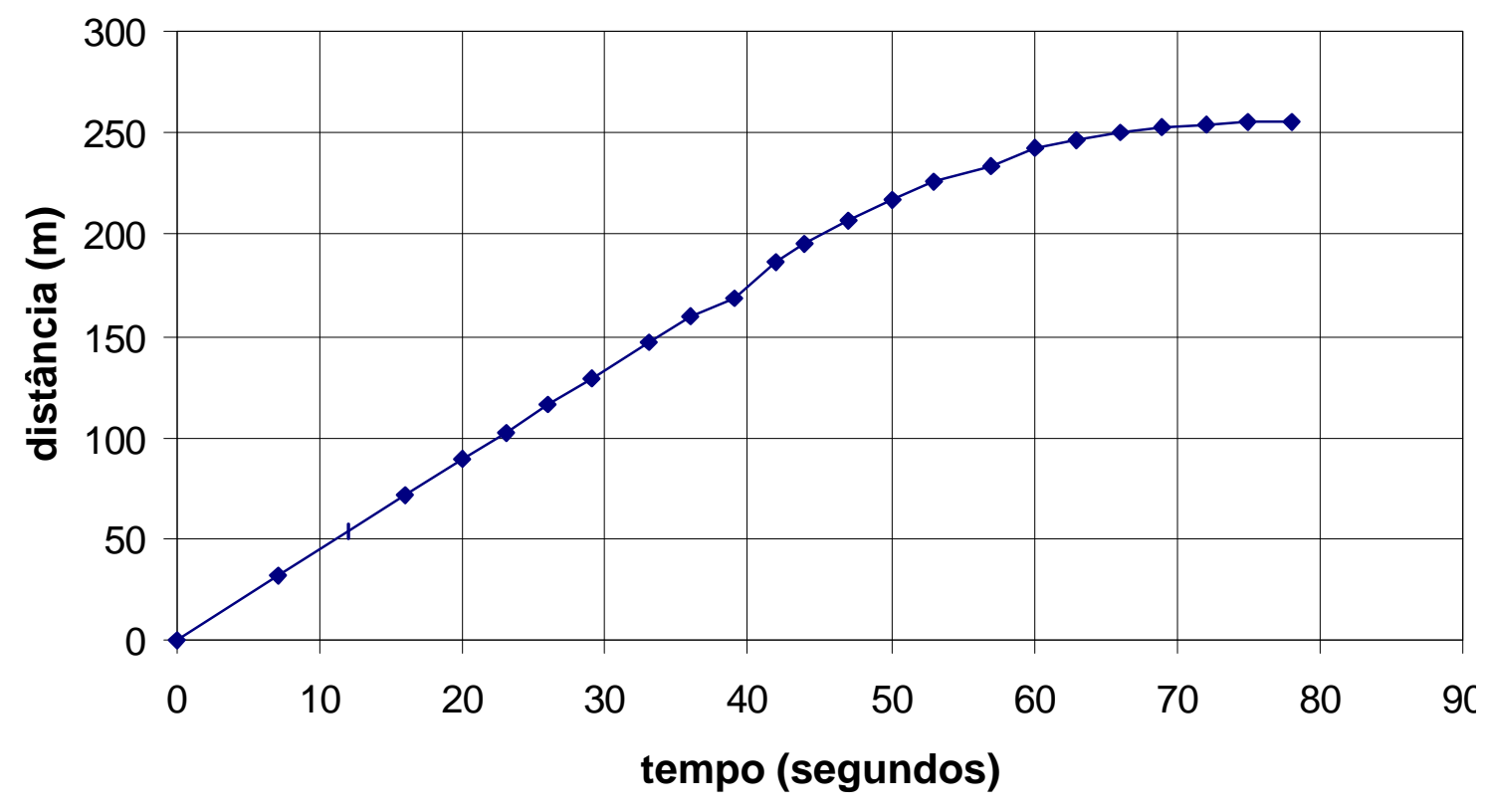

Figura 4.1- Ensaio de parada brusca de comboio com duas chatas vazias em linha, rio Tietê, escala real, $\mathrm{Vo}=4,25 \mathrm{~m} / \mathrm{s}$. O modelo obteve $235,3 \mathrm{~m}(-7 \%)$

\subsubsection{Manobras de Comboios com Chatas Vazias}

A experiência tem mostrado que uma condição crítica de manobras é aquela em que comboios trafegam com chatas vazias e ficam sujeitos à ação de ventos de través em suas grandes áreas fora da água (Figura 4.2). Apesar de possuírem uma grande relação potência instalada por massa, os comboios vazios têm problemas para manter o rumo sob ação de forças externas. Sistemas auxiliares de manobras ajudam a resolver a situação, mas nem sempre são instalados. Brolsma et al. (1988) considera 
praticamente indispensável a utilização de sistemas auxiliares de manobras para o controle de comboios com chatas vazias.

O modelo deverá fazer uma comparação entre as forças e momentos decorrentes de ventos em comboios vazios, e as forças e momentos resultantes do acionamento dos lemes. O módulo ventos, que será apresentado a seguir, estima, com precisão adequada, as forças de ventos sobre as embarcações.

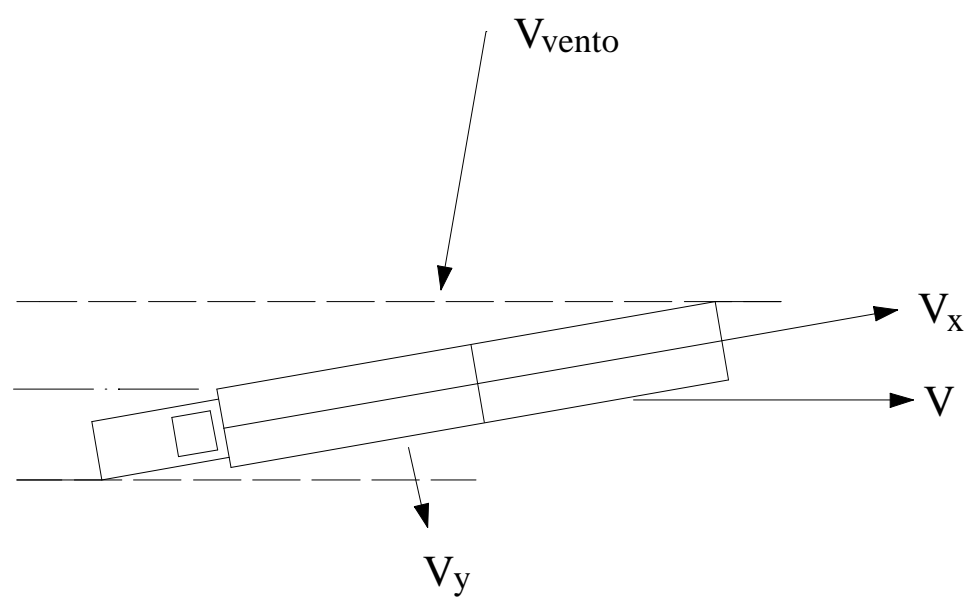

Figura 4.2 - Efeito da ação de ventos sobre comboio com chatas vazias

O módulo manobras calcula as forças nos lemes, conhecendo-se as áreas dos lemes $A_{L}$, adotando valores de coeficientes de sustentação $C_{L}$, conhecendo o ângulo do vento, relativo à embarcação, e obtendo-se a velocidade de saída dos hélices $U_{2}$ (para o caso, mais comum, de lemes posicionados na esteira dos hélices). Assim, é obtida a força normal ao leme: $F_{N}=\frac{1}{2} \cdot \rho \cdot C_{L} \cdot A_{L} \cdot U_{R}{ }^{2} \cdot \sin \alpha_{R}$, onde $U_{\mathrm{R}}$ e $\alpha_{\mathrm{R}}$ são, respectivamente, a velocidade no leme e o ângulo de entrada do escoamento no leme.

Com o valor da força nos lemes, é calculado o momento, adotando, como braço de aplicação, metade do comprimento do conjunto de chatas somado ao comprimento do empurrador.

O comboio apresenta uma reação hidrodinâmica contrária à ação do vento, que, não será considerada nas comparações, procedimento este a favor da segurança. 
Os coeficientes de sustentação dos lemes convencionais são assumidos com o valor aproximado $\mathrm{C}_{\mathrm{L}}=1,0$ e para os de lemes com "flaps", adotou-se $\mathrm{C}_{\mathrm{L}}=1,4$ (Olson, 1955).

No caso de haver sistemas auxiliares na proa, então são, também, calculados as forças e momentos correspondentes, os quais entram na composição para verificação do ângulo de deriva resultante do comboio sob a ação de ventos. Os efeitos de lemes de proa são calculados a partir de resultados de IPT (1981), mostrados no ANEXO B, e os efeitos de impelidores laterais ("bow thruster" ou hélices de proa) são calculados a partir de resultados experimentais mostrados em Brolsma et al. (1988).

\subsection{Módulo Custos}

O módulo custos calcula os custos totais (operacionais e de capital) de um determinado comboio, composto por um empurrador e por um conjunto de chatas, em uma dada via navegável.

\subsubsection{Formulação de modelo de cálculo de custos}

Os custos de transportes podem ser divididos em custos fixos, que independem da operação das embarcações, e em custos variáveis, diretamente ligados à operação das embarcações.

Os custos fixos são:

depreciação das embarcações e remuneração do capital;

salários da tripulação, incluindo encargos sociais;

rancho (alimentação) da tripulação embarcada;

manutenção e docagens das embarcações;

taxas, impostos e vistorias;

$>$ administração.

Os custos variáveis são:

- combustíveis consumidos; 
- lubrificantes consumidos;

- outros consumíveis;

- custos de terminais de carga e de descarga.

\subsubsection{Parâmetros descritivos do problema}

Para a obtenção dos custos de transporte de cargas por comboio fluvial, devem ser definidos os seguintes parâmetros:

- características da via;

- características da embarcação;

- características dos portos.

Nos tópicos seguintes será apresentada a descrição detalhada de cada parâmetro.

\section{A) Caracterização da Via}

Considerando os portos de origem e de destino das cargas, são utilizados os dados referentes aos trechos da via. Assim, são calculados os custos em cada trecho específico, somando-se, ao final, os subtotais. Se houver vários portos, com diferentes cargas entre eles, também serão levados em consideração nos cálculos.

Para efeito da metodologia de cálculo de custo que será adotada, a caracterização da via é feita através dos seguintes dados:

Dt - distância entre o ponto de início e de final de um trecho [km];

$1 / \mu \quad$ tempo médio de atendimento em cada operação de eclusagem ou de passagem por canais estreitos [h]

$\sigma \quad$ desvio padrão do tempo de atendimento em operações de eclusagem ou de passagem por canal estreito $[\mathrm{h}]$;

$\lambda \quad$ fluxo médio de chegada de embarcações por unidade de tempo nos dois sentidos; indica o nível de congestionamento da via (comboios por hora);

IDV índice de disponibilidade da via, indica em fração do número de dias por 
ano que a via apresenta profundidade favorável à navegação; em vias totalmente canalizadas, sem interrupções ao longo do ano, esse número é igual a 1 .

\section{B) Caracterização da Embarcação}

No caso de comboios a caracterização da embarcação pode ser dividida em três partes: chata, empurrador e formação do comboio.

\section{Chata}

Lchata comprimento [m];

Bchata boca $[\mathrm{m}]$;

Pchata pontal $[\mathrm{m}]$

CB coeficiente de bloco;

Kc coeficiente de peso em aço $\left[\mathrm{t} / \mathrm{m}^{3}\right]$.

Peso em aço de uma chata:

$$
P_{P a c o} \text { chata }=K c \cdot \text { Lchata } \cdot \text { Bchata } \cdot \text { Pchata } \quad[\mathrm{t}] \text {. }
$$

A capacidade de carga:

$$
\begin{gathered}
\text { DWT }=\text { CB.L.B.H }- \text { Paco }_{-} \text {chata } \quad[\mathrm{t}], \\
\text { da água igual a } \left.1 \mathrm{t} / \mathrm{m}^{3}\right) .
\end{gathered}
$$

\section{C) Formação do Comboio}

Para definir o comboio é necessário fornecer o número de linhas e de colunas de chatas:

nLinhas número de linhas de chatas;

nColunas número de colunas de chatas.

Capacidade de carga do comboio:

$$
D W T c=n \text { Linhas } \cdot n \text { Colunas } \cdot D W T
$$

Peso em aço do conjunto de chatas (peso leve): 


$$
\text { peso_leve }=n \text { Linhas } \cdot n \text { Colunas } \cdot \text { Paco_chata }
$$

\section{Empurrador}

A potência utilizada, em $\mathrm{kW}$, em cada trecho percorrido da via, será obtida a partir dos parâmetros da via e do comboio, com auxílio da formulação de Howe (Christopoulos \& Latorre, 1983), introduzida em 4.1.1.

Adicionalmente, é necessário definir:

turno número de horas úteis por dia que o comboio opera;

Ntrip número de tripulantes.

\section{D) Caracterização dos Portos}

Os portos podem ser caracterizados conhecendo-se:

txcarga taxa de carregamento $[\mathrm{t} / \mathrm{h}] ;$

txdescarga taxa de descarregamento $[\mathrm{t} / \mathrm{h}]$;

horas_term quantidade de horas úteis por dia que operam os terminais [h];

espera_term parcela do tempo de carga/descarga realmente utilizada para espera (de 0,1 a 1,0$)$.

No caso de comboios, há uma facilidade para se obter uma redução importante de tempos em terminais, colocando-se à disposição do empurrador recém-chegado ao terminal, chatas já carregadas ou já vazias, conforme o caso. Este procedimento operacional pode ser adotado se houver chatas extras disponíveis e poderá ser levado em consideração no módulo custos pelo dado de entrada espera_term.

\subsubsection{Tempos operacionais}

\section{Tempo de Ciclo}

O tempo de ciclo de um comboio (TC), dado em dias, é obtido pela soma da duração da viagem DurV, com a duração das operações de carga e descarga DurOper: 


$$
T C=\text { DurV }+ \text { DurOper } \quad[\operatorname{dias}]
$$

DurV, que é a duração de uma viagem redonda, depende do tempo de viagem (em horas) e do número de horas úteis de operação por dia (turno).

Assim: $\operatorname{DurV}=\frac{T V}{\text { turno }}$, onde o tempo de viagem $T V$ (em horas) de um comboio corresponde à soma das seguintes parcelas de tempo:

$T V=T$ Vnavegando $+T A d p \quad[\mathrm{~h}], \quad$ em que TAdp é o tempo adicional parado e TVnavegando é obtido como: TVnavegando $=T N+T A d n \quad[\mathrm{~h}]$, em que $T N$ é o tempo navegando; TAdn é o tempo adicional navegando.

\section{Tempo Navegando $(T N)$}

O tempo navegando $(T N)$ é aquele em que os motores principais de propulsão estão acionados e a embarcação avança em sua velocidade normal de cruzeiro. É calculado pela somatória dos tempos em todos os trechos da via, na ida e na volta (em 2 * nTrechos): $T N=\sum_{1}^{2 * n T r e c h o} \frac{D t}{\text { Vreal }}$, sendo Vreal a velocidade referida à terra, de cada trecho.

\section{Tempos Adicionais Navegando (TAdn)}

Esta parcela de tempo corresponde aos acréscimos de tempo de navegação que podem ocorrer em decorrência de peculiaridades de algum trecho da via que impliquem tempos adicionais de navegação, tais como tempos de manobra, de passagens difíceis, de desmembramentos, etc. Devem ser considerados todos os tempos adicionais na viagem redonda do comboio, até o retorno ao porto de origem, nos quais os motores de propulsão permanecem ligados. Em cada situação particular, o tempo pode ser calculado a partir do tempo médio de atendimento dessa operação. O tempo total pode, então, ser obtido pela somatória de todas as parcelas para as $\boldsymbol{p}$ situações, multiplicando-se o resultado por dois (ida e volta).

$$
T A d n=2 \sum_{i=1}^{p} \frac{1}{\mu_{i}} \quad[\mathrm{~h}]
$$


p número de locais onde a transposição é feita com os motores ligados, por exemplo, em canais

Os tempos adicionais navegando serão calculados nas várias funções correspondentes a canais, eclusas, curvas e pontes, onde podem ocorrer desmembramentos ou outra operação realizada com motores do empurrador ligado. A soma dos valores, TAdn, é feita no módulo custos.

\section{Tempos Adicionais Parado (TAdp)}

O tempo adicional parado é o tempo em viagem durante o qual o comboio permanece parado, com os motores principais de propulsão desligados. Tais situações ocorrem nos casos em que houver espera e nos quais a transposição em si não depende da propulsão da embarcação, como por exemplo uma transposição de eclusa, ou uma transposição de canal feita por rebocador auxiliar. Esse tempo corresponde a $2 \mathrm{x}$ TSist, onde TSist é o tempo de sistemas de transposição.

Devem,também, ser incluídas as parcelas de tempo de espera em canais e em eclusas, TEsp. Assim:

$$
\text { TAdp }=2 \sum_{i=1}^{q} \text { TSist }_{i}+2 \sum_{j=1}^{p} \text { TEsp }_{j} \quad[\mathrm{~h}], \text { onde }
$$

$q$ é $o$ número de locais de transposição onde os motores principais permanecem desligados, por exemplo, em eclusas e $p$ é o número de locais onde há apenas espera.

Os valores de TSist e de Tesp são calculados pelo módulo eclusas_canais.

\section{Duração das Operações de Embarque e Desembarque de Carga}

$$
\text { DurOper }=\frac{(\text { tempo_c } \arg a+\text { tempo_desc } \arg a) \cdot \text { espera } \_ \text {carg } a}{\text { horas_term }}
$$

Os tempos de embarque e desembarque dependem da capacidade de carga do comboio e das taxas de carga e descarga dos terminais hidroviários. Assim: 


$$
\begin{aligned}
& \text { tempo_c } \arg a=\frac{\left(\text { dif }_{-} c \arg a>0\right)}{t x c a r g a}, \\
& \text { tempo_desc } \arg a=\left|\frac{(\text { dif_c } \arg a<0)}{t x d e s c}\right| .
\end{aligned}
$$

Os valores de dif_carga são obtidos pela diferença entre a carga existente em um comboio na saída de terminal e na saída do terminal anterior, a fim de determinar quanto de carga foi embarcada (dif_carga > 0) ou quanto foi desembarcada (dif_carga $<0)$.

O valor espera_carga é a fração do tempo total de carga e descarga que deverá ser computado no tempo total da viagem (valores entre 0,1 e 1,0). Este fator é necessário porque há formas de operar que diminuem os tempos em terminais, já deixando à espera do empurrador chatas carregadas ou descarregadas. Contudo, os tempos em terminais nunca serão nulos, já que sempre são despendidos tempos em manobras, amarrações de chatas, reabastecimentos e possíveis trocas de tripulações.

Calculado o tempo de ciclo de um comboio é possível calcular o número de viagens anual de um comboio, fazendo: $N V c=\frac{365-N D I}{T C}$, onde $N D I$ é o número de dias inativos (águas baixas, manutenção, docagens, etc.) e $N D I=365 .(1-I D V)+N D M$, sendo NDM $o$ número de dias em manutenção (este poderá ser igual a zero se coincidir com os dias em que a via não opera).

A produção anual do comboio, isto é, a quantidade total de carga transportada em um ano, pode então ser obtida:

$P A C=N V c \cdot C \arg a_{-}$total.

\subsubsection{Cálculo dos Custos}

São calculados os custos do comboio por hora parada e os custos do comboio por hora navegando, de forma que, multiplicando estes valores aos respectivos tempos, parado e navegando, se obtém os custos totais, em cuja soma ainda entram os custos referentes à operação dos terminais. 


\section{Custo Parado}

O custo horário do comboio parado (Cparado) é o custo que incide sobre o comboio quer ele opere ou não. Pode ser obtido, de um modo simplificado, somando-se os custos fixos e dividindo-se pelo número total de horas do ano $\left(365^{* 24}=8760 \mathrm{~h}\right)$. Obtém-se o custo em reais por hora do comboio parado, porém armado e pronto para operar.

$$
\text { Cparado }=\frac{\text { Ccapital }+ \text { CSalario }+ \text { Crancho }+ \text { Cdocagem }+ \text { Cseguro }+ \text { Cadm }}{8760},
$$

onde os parâmetros da expressão são definidos a seguir.

\section{Custo de Capital $(C c)$}

Corresponde ao custo para compra do comboio a uma taxa de juros anual num período de n anos, conforme a expressão abaixo:

$$
\begin{aligned}
& \text { Ccapital }=\operatorname{Pr} \text { atual } \frac{\text { juros }(1+\text { juros })^{n}}{(1+\text { juros })^{n}-1} \\
& \operatorname{Pr} \text { atual }=\text { Preco_chatas }+\operatorname{Pr} e c o_{-} \text {empurrador }-\frac{1}{(1+\text { juros })^{n}} * \\
& *\left(V R c \cdot \operatorname{Pr} e c o \_ \text {chatas }+V \operatorname{Re} m p \cdot \operatorname{Pr} e c o \text { empurrador }\right) \\
& \text { Preco_chatas }=\text { preco_aco_chata } \cdot \text { Paco_chata } \cdot n \text { Colunas } \cdot n \text { Linhas } \\
& \text { Preco_empurrador }=\text { preco_aco_emp } \cdot \text { Paco_emp }+ \text { cte_maq } \cdot \text { MCR } \cdot \text { nMotor }
\end{aligned}
$$

Onde:

juros - taxa de juros anual;

$n$ - período de retorno em anos;

preço_aco_chata - preço do aço de chatas, em reais por tonelada;

preço_aco_emp - preço do aço de empurrador, em reais por tonelada;

cte_maq - preço das máquinas do empurrador em reais por $\mathrm{kW}$; 
$V R c$ - valor residual das chatas, dado como uma fração do preço das chatas;

VRemp - valor residual do empurrador, dado como uma fração do preço do empurrador.

\section{Salários e Encargos (CSalario)}

É obtido pela soma dos salários mais encargos de todos os tripulantes.

CSalario $=12 .[$ Ntrip $+($ Ntrip -1$) / 2]$. Salario_medio.enc $\arg$ os

Ntrip - número de tripulantes do comboio, sendo acrescentados (Ntrip-1)/2, arredondados para baixo, a fim de contemplar os revezamentos (folgas e férias) da tripulação.

Salario_médio - Salário médio em reais por mês por tripulante

encargos - Encargos sociais - porcentagem do salário que fornece os encargos sociais: contribuições sociais, décimo terceiro, adicional de férias, etc.

\section{Rancho (Crancho)}

É o custo de alimentação da tripulação.

Crancho $=365$. Ntrip.rancho_dia

rancho_dia é o custo médio diário, em reais, da alimentação por tripulante embarcado.

\section{Docagens (Cdocagem)}

\section{Cdocagem $=$ Cmanut $\cdot \operatorname{Pr}$ atual}

$\mathrm{O}$ custo de docagem corresponde à média anual dos custos relacionados com docagens e manutenção.

Cmanut corresponde a uma fração do preço atualizado do comboio.

\section{Seguro (Cseguro)}

$$
\text { Cseguro }=\text { fracao_seg } \cdot \operatorname{Pr} \text { atual }
$$


fracao_seg - corresponde a uma fração do preço atualizado do comboio.

\section{Administração (Cadm)}

O custo de administração pode ser estimado a partir dos demais custos:

Cadm $=$ fracao_adm. $($ Ccapital + CSalario + Crancho + Cdocagem + Cseguro $)$, onde fracao_adm corresponde à uma fração das somas dos demais custos.

\section{Custo Navegando $(\mathrm{CN})$}

O custo navegando $(C N)$ é aquele associado ao consumo de combustível, óleo lubrificante e outros consumíveis, e só incide quando o comboio efetivamente opera. Pode ser calculado considerando-se o consumo específico dos motores diesel (Cespod).

O consumo de óleo lubrificante depende do tipo de motor utilizado, em geral é uma fração em volume do consumo de óleo diesel.

Outros custos estão associados aos consumíveis diversos e podem ser estimados à partir do custo referente ao consumo de óleo diesel.

Cespod - consumo específico de óleo diesel [litro/kW/h];

CuOD - custo por litro de óleo diesel;

Rol - fração de valores entre os custos referentes aos consumos de óleo lubrificante e o de óleo diesel;

Fcons - custo de consumíveis diversos.

- Custo de óleo diesel:

$C_{-} O_{-} D=(1+$ Fgerador $) \cdot C u O D \cdot P o t_{-}$media $*$ Cespod

Foi incorporado o fator Fgerador a fim de somar os gastos de óleo diesel devido à operação dos geradores a bordo. 
Fgerador - fração entre o consumo de óleo Diesel por geradores e pelos motores principais do empurrador.

Pot_média - potência média ponderada utilizada pelos motores principais do empurrador durante toda a viagem .

- Custo de óleo lubrificante:

$$
C_{-} O_{-} L=R o l \cdot C_{-} O_{-} D
$$

- Custo de outros consumíveis:

$$
\text { Ccons }=F \text { cons } \cdot C_{-} O_{-} D
$$

O custo total navegando pode então ser obtido:

$$
\text { Cnavegando }=\text { Cparado }+C_{-} O_{-} D+C_{-} O_{-} L+C \text { cons }
$$

\subsubsection{Custo Total e Fator de Mérito}

O custo total é obtido somando-se as parcelas devidas ao tempo parado e ao tempo navegando:

$$
\begin{aligned}
& \text { Ctotal }=\text { Cnavegando } \cdot T N T+\text { Cparado } \cdot T P T+\text { Cter min ais } \\
& T N T=N V c .(T N+T A d n)[\mathrm{h}] \\
& T P T=8760-T N T[\mathrm{~h}] \\
& \text { Cterminais }=\text { custo_t_term } . \text { PAC } .2
\end{aligned}
$$

Assim, o custo por tonelada pode ser obtido:

$$
\text { Custo_tonelada }=\frac{\text { Ctotal }}{P A C}
$$

E o custo por tonelada.km: 


$$
\text { Custo_tonelada_km }=\frac{\text { Custo_tonelada }}{\text { Dist_total }}
$$

É definido um fator de mérito de transporte como a relação entre a capacidade de carga, a velocidade média do comboio e a potência média despendida (Bilen \& BilenKatic, 1997):

$$
\text { fator_merito }=\frac{c \arg a_{-} \text {total } \cdot \text { Vel_media }}{\text { Pot_media }} \quad\lceil+.
$$

\subsection{Módulo Riscos}

de ocorrência de acidentes, que dependem das características físicas da via, da qualidade dos sistemas principais da embarcação (propulsão, manobras, estrutura), do

fatores ambientais como ventos e neblina.

O módulo do modelo tem o objetivo de proporcionar uma avaliação dos riscos envolvidos na navegação pelo comboio em estudo em cada trecho da hidrovia.

(Roeleven et al., 1995): identificação dos riscos existentes; determinação da exposição ao risco e estimativa do risco a que se está exposto.

O risco de um desastre potencial pode ser calculado pela combinação da freqüência, ou probabilidade de ocorrência, com as possíveis consequiências, ou impactos

Risco $=$ função $[$ Freqüência (ou probabilidade),

(ou impacto)]

que permitem, após sua combinação, uma quantificação do risco. 
As Tabelas 4.3 e 4.4 apresentam, respectivamente, uma classificação típica das conseqüências e uma classificação de freqüência de ocorrência de acidentes (USCG, 2000).

Tabela 4.3 - Uma matriz de conseqüências de acidentes em hidrovia (USCG, 2000)

\begin{tabular}{|l|l|}
\hline Gravidade & \multicolumn{1}{|c|}{ Definição } \\
\hline ALTA & $\begin{array}{l}\text { Morte(s) e/ou grandes danos materiais (infra-estrutura da hidrovia, } \\
\text { perda de embarcação) e/ou grandes danos ambientais }\end{array}$ \\
\hline MÉDIA & $\begin{array}{l}\text { Ferimentos e/ou doenças graves e/ou danos materiais significativos } \\
\text { (infra-estrutura da hidrovia, embarcações) e/ou danos ambientais } \\
\text { significativos }\end{array}$ \\
\hline BAIXA & $\begin{array}{l}\text { Ferimentos e/ou doenças leves e/ou danos materiais leves (infra- } \\
\text { estrutura da hidrovia, embarcações) e/ou danos ambientais leves }\end{array}$ \\
\hline
\end{tabular}

Tabela 4.4 - Uma matriz de freqüência de ocorrência de acidentes em hidrovia (USCG, 2000).

\begin{tabular}{|l|l|}
\hline \multicolumn{1}{|c|}{ Categoria } & \multicolumn{1}{c|}{ Descrição } \\
\hline Muito Freqüiente & 10 a 100 eventos por ano \\
\hline Freqüente & 1 a 10 eventos por ano \\
\hline Ocasional & 1 evento a cada 5 anos \\
\hline Raro & 1 evento a cada 10 anos \\
\hline Muito Raro & 1 evento a cada 20 anos ou mais \\
\hline
\end{tabular}


A combinação das duas matrizes possibilita a obtenção de níveis de riscos de cada tipo de acidente com determinada embarcação em uma hidrovia definida (Tabela 4.5).

determinada hidrovia, o nível de risco existente. Se o nível de risco detectado for considerado alto ("alto risco"), serão emitidos avisos para a adoção de medidas que

necessitam de atenção especial de armadores, operadores de embarcações e administradores da hidrovia.

- Caracterização gráfica do risco

\begin{tabular}{|l|c|c|c|}
\hline & Baixa gravidade & & Alta gravidade \\
\hline Muito raro & Baixo risco & Médio risco & Médio risco \\
\hline Raro & Baixo risco & Médio risco & Alto risco \\
\hline Ocasional & Baixo risco & Médio risco & Alto risco \\
\hline Freqüente & Médio risco & Alto risco & Alto risco \\
\hline Muito freqüente & Médio risco & Alto risco & Alto risco \\
\hline
\end{tabular}

\subsubsection{Tipos de acidentes com comboios em hidrovias brasileiras}

Os tipos de acidentes a que estão expostos os comboios nas hidrovias brasileiras foram identificados. A escolha dos tipos de acidentes foi baseada em registros escassos e incompletos de acidentes, e também baseada na experiência acumulada, no IPT, com participação do autor, em estudos de segurança de navegação de comboios fluviais (hidrovias Tocantins-Araguaia, Tietê-Paraná, Paraguai-Paraná, Amazônia e Lagoa dos Patos).

No caso das hidrovias brasileiras, a partir da experiência acumulada e de algumas referências bibliográficas (Ferreira, 2000; Kite-Powell et al., 1998; Brolsma et al., 
são ocorrências que podem resultar em acidentes) mais importantes para a elaboração de uma avaliação de riscos da navegação de comboios de cargas:

encalhes;

choques de embarcação com fundo rochoso;

colisões entre embarcações;

colisões do comboio com estruturas na via (barragem, entrada de

e)

f)

afetando as partes externas dos sistemas de propulsão e manobras;

g) ruptura de amarras entre chatas e/ou entre empurrador e chatas;

h) incêndios, explosões;

i) falhas de equipamentos do empurrador.

O presente modelo levará em conta os tipos de acidentes de a $\mathbf{f}$ de maior importância para uma análise dos riscos de ocorrência de acidentes, resultantes da inter-relação entre as características de uma hidrovia com os comboios

$\mathbf{g}, \quad, \mathbf{i}$

que independem da relação direta hidrovia-comboio.

A seguir, serão feitas considerações sobre os acidentes levados em conta no modelo

conseqüências.

a) - trata-se de um tipo de acidente freqüente em trechos de águas rasas e com fundo arenoso, geralmente com movimentação de bancos de areia ao longo do

tripulação e com pequenos danos à embarcação. Contudo, a ocorrência de encalhes resulta em prejuízos ao transporte, já que aumenta o tempo da embarcação parada e 
há dispêndio de um volume adicional de combustível nas operações de desencalhe. Uma observação importante: o projeto estrutural das chatas deve prever situações de encalhe durante sua vida útil. O modelo adotará freqüência alta ("muito freqüente") para trechos de águas rasas com fundo arenoso, onde o pé-de-piloto seja menor que um metro. Quanto às consequiências, será dada a atribuição de "baixa gravidade". Haverá, contudo, indicação de acréscimos de custos (tempo parado e combustível adicional). Em locais em que o pé-de-piloto for maior que 1 metro e menor que duas vezes o calado máximo, a probabilidade de ocorrência de choques no fundo será considerada pequena ("ocasional"). Quando o pé-de-piloto for maior que duas vezes o calado máximo do comboio, a classificação será de "rara".

b) Choque com fundo rochoso - este tipo de acidente tem conseqüências maiores que os encalhes porque geralmente resultam em rupturas dos cascos. Se as chatas estiverem carregadas com produtos perigosos (combustíveis, produtos químicos, etc.) as conseqüências de um acidente deste tipo são gravíssimas. O modelo adotará classificação de "freqüente" em caso de trechos em águas rasas com fundo rochoso com pé-de-piloto menor que um metro. Quanto às conseqüências, elas serão de "alta gravidade" se houver transporte de produtos perigosos e de "média gravidade" se as cargas forem de outro tipo (grãos, carga geral, contêineres). Em locais em que o péde-piloto for maior que 1 metro e menor que duas vezes o calado máximo, a probabilidade de ocorrência de choques no fundo será considerada pequena (“ocasional"). Quando o pé-de-piloto for maior que duas vezes o calado máximo do comboio, a classificação será de "rara".

c) Colisão entre embarcações - este tipo de acidente depende muito do volume de tráfego, da forma de operação e dos sistemas de navegação e de comunicação das embarcações. Mas, também depende das características da via (trechos em curvas, presença de correnteza forte), das embarcações (desempenho propulsivo e manobrabilidade) e das condições ambientais (visibilidade, ventos, ondas). No atual estágio das hidrovias brasileiras, onde o tráfego de embarcações é ainda pequeno, este tipo de acidente pode ser classificado como "ocasional". As consequiências, dependendo do tipo de embarcações envolvidas em uma colisão, podem ser de alta a média gravidade. 


\section{d) Colisões com estruturas da via}

de acidentes deste tipo dependem do tipo de estrutura existente em cada hidrovia. No caso de colisões com pontes e com barragens, as conseqüências serão sempre de "alta

civis ou mecânicas das eclusas, podendo ser classificadas de "média gravidade". A freqüência é diretamente dependente das características das estruturas existentes na

freqüentemente colidirão com pilares de pontes se o vão de navegação for relativamente estreito.

Choques com margens do rio - este tipo de acidente ocorre em trechos da via

a manobrabilidade da embarcação e as condições ambientais. Em trechos curvos e em trechos muito estreitos, a frequiência será definida como "freqüente" e as

\section{f) Choques com troncos}

certa possibilidade de ocorrência deste tipo de choque. As conseqüências para um comboio são de "baixa gravidade", geralmente afetando hélices e lemes do

conseqüências maiores ("média gravidade"), principalmente se o local do evento for crítico (por exemplo, em aproximação de ponte, em curva fechada ou em local com

custos de manutenção. A freqüência deste tipo de ocorrência será um dado de entrada do modelo.

As faixas de freqüências e de consequiências esperadas dos vários tipos de acidentes que podem ocorrer nas hidrovias brasileiras, resultantes da inter-relação entre via 
Tabela 4.6 - Resumo dos tipos de acidentes e faixas de freqüências e de suas conseqüências esperadas

\begin{tabular}{|c|c|c|}
\hline Tipo de acidente & Freqüência esperada & Conseqüências \\
\hline Encalhes & $\begin{array}{l}\text { Se } \mathrm{h} \leq \mathrm{Tmax}+1 \mathrm{~m}: \text { "muito freqüente" } \\
\text { Se Tmax }+1<\mathrm{h}<2 . \text { Tmax: "ocasional" } \\
\text { h > 2.Tmax: "rara" }\end{array}$ & Baixa gravidade \\
\hline $\begin{array}{l}\text { Choques com } \\
\text { fundo rochoso }\end{array}$ & $\begin{array}{l}\text { Se h } \leq \text { Tmax }+1 \mathrm{~m}: \text { "freqüente" } \\
\text { Se Tmax }+1<\mathrm{h}<2 . \text { Tmax: "ocasional" } \\
\text { h }>\text { 2.Tmax: "rara" }\end{array}$ & $\begin{array}{l}\text { Alta gravidade com } \\
\text { cargas perigosas e } \\
\text { Média gravidade com } \\
\text { outras cargas }\end{array}$ \\
\hline $\begin{array}{l}\text { Choques entre } \\
\text { embarcações }\end{array}$ & ocasional & Alta gravidade \\
\hline $\begin{array}{l}\text { Choques com } \\
\text { pontes }\end{array}$ & de ocasional a freqüente & Alta gravidade \\
\hline $\begin{array}{l}\text { Choques com } \\
\text { outras estruturas } \\
\text { da via }\end{array}$ & de ocasional a freqüente & Média gravidade \\
\hline $\begin{array}{l}\text { Choques com } \\
\text { margens }\end{array}$ & Em trechos curvos e estreitos: freqüente & Baixa gravidade \\
\hline $\begin{array}{l}\text { Choques com } \\
\text { troncos }\end{array}$ & $\begin{array}{l}\text { Depende da hidrovia, de raro a muito } \\
\text { frequiente }\end{array}$ & Média gravidade \\
\hline
\end{tabular}

\subsubsection{Freqüências e conseqüências}

A partir da definição dos tipos de acidentes e de suas faixas esperadas de freqüências e de suas respectivas conseqüências, resumidas na Tabela 4.6, deve haver um modelo para estimar os valores de frequiências (ou probabilidades) de acidentes para, então enquadrá-los em uma das cinco faixas de classificação da freqüência. Os níveis de consequiências serão considerados pré-determinados, fixos em uma das três faixas escolhidas (baixa, média ou alta gravidade), conforme indicado na Tabela 4.6.

Uma embarcação que transporta produtos perigosos por um trecho de águas rasas com fundo rochoso e correnteza, com pé-de-piloto reduzido, sistemas de propulsão e de manobras pouco eficientes e em condições adversas de visibilidade e de ventos, certamente apresentará um risco considerável de ocorrência de um acidente grave. A 
soma destes fatores de riscos pode ser evitada nos vários estágios da corrente de risco, introduzida na Figura 2.4 do Capítulo 2:

causas básicas:

- evitar sistemas de propulsão e de manobras ineficientes;

a possuir projeto estrutural e de compartimentagem adequados (casco duplo, por exemplo);

- dispor de bons sistemas de navegação e de comunicação;

causas imediatas:

- evitar operação com pé-de-piloto reduzido, resultante de um calado maior que o requerido por questões de segurança;

- evitar navegar por trechos mais críticos da via durante períodos em que há visibilidade reduzida e ventos de grande intensidade;

- monitorar o tráfego de outras embarcações na região para que seja evitado um encontro de embarcações em locais críticos.

A probabilidade (ou frequiência estimada) de ocorrência de cada tipo de acidente não pode ser obtida a partir de uma análise de dados estatísticos porque não há, no Brasil, um conjunto de registros de acidentes de comboios fluviais. O número de acidentes é relativamente reduzido, porque o transporte cargas por comboios no Brasil é ainda pouco volumoso.

Alguns registros de casos específicos, como o de colisões de comboios ocorridos em pilares de pontes do rio Tietê, podem ser utilizados para avaliar os fatores de riscos presentes naqueles casos. Por exemplo, na análise das colisões de comboios em pilares de pontes, ficou evidente que o maior fator de risco era a navegação de comboios sem cargas, em condições desfavoráveis de ventos, o que resultava em um precário controle das trajetórias das embarcações. As soluções indicadas, e adotadas com sucesso, para a redução dos riscos foram: aumento dos vãos entre pilares das 
pontes, instalação de sistemas de proteção de pilares e diminuição dos comprimentos e/ou larguras dos comboios durante as passagens sob as pontes, com a utilização de desmembramentos dos conjuntos de chatas.

O modelo para obtenção das probabilidades de ocorrências de cada tipo de acidentes, foi desenvolvido utilizando dados de acidentes em referências bibliográficas e levando em conta todos os fatores considerados como de risco nas hidrovias brasileiras, listados a seguir.

\section{Fatores de riscos:}

ventos e/ou ondas fortes;

visibilidade inadequada;

potência instalada no empurrador insuficiente para enfrentamento de situações críticas;

$>$ manobrabilidade ruim;

$>$ comboio com chatas vazias;

altas velocidades de correntes;

curvas fechadas;

trechos estreitos;

trechos em águas rasas;

passagens estreitas (vãos de pontes, entradas de eclusas);

grande volume de tráfego de embarcações (este não será considerado no decorrer do estudo, porque há uma hipótese inicial de ainda não haver tráfego intenso de embarcações pelas hidrovias brasileiras). 
No modelo, não foram incluídos alguns fatores que podem influenciar os níveis de riscos, mas que apresentam um caráter mais particular e sem ligação direta com a relação via-comboio, como preparo e atuação da tripulação, existência de sistemas de navegação e de comunicação, utilização ou não de sociedade classificadora, idade da embarcação, possível pressão de armadores sobre a tripulação, etc.

\subsubsection{Estimativa de probabilidade de ocorrência de acidentes}

A probabilidade de ocorrência de acidentes pode ser calculada utilizando o Teorema de Bayes (Kite-Powell et al., 1998). A probabilidade condicional de A ocorrer, dado um valor específico x de um vetor de variáveis (no presente caso, os fatores de risco) $\mathrm{X}$, é dada por:

$$
p(A \mid x)=\frac{l(x \mid A)^{*} p}{l(x \mid A)^{*} p+l(x \mid S)^{*}(1-p)}
$$

onde p é a probabilidade incondicional de $\mathrm{A}$, e $l(\mathrm{x} \mid \mathrm{A})$ e $l(\mathrm{x} \mid \mathrm{S})$ são as probabilidades de $\mathrm{x}$, dados $\mathrm{A}$ e $\mathrm{S}$, respectivamente. $\mathrm{S}$ denota o evento em que a passagem da embarcação é completada com segurança. A probabilidade incondicional p pode ser obtida como uma média ponderada de dados históricos de taxa do tipo escolhido de acidentes, referenciada ao número de passagens de embarcações pela via. Seus valores são dados, portanto, em números de acidentes do tipo por um certo número de passagens adotado como referência. Este número arbitrário, será fixado em 1000 passagens de comboios.

Como existe um número reduzido de registros de acidentes com comboios fluviais no Brasil (Ferreira, 2000), serão adotados valores baseados em estatísticas dos Estados Unidos e da Europa. Mesmo internacionalmente os dados de acidentes com comboios são relativamente escassos e incompletos (Kite-Powell at al., 1998). O ANEXO C apresenta os dados considerados na obtenção de algumas probabilidades de acidentes para utilização no modelo. Alguns dados de probabilidade incondicional p serão fornecidos pelo usuário, como no caso da presença de troncos flutuando em uma 
hidrovia; assim, deve ser fornecido p em número de choques com troncos por 1.000 passagens de comboios.

Para cada tipo de acidente A será calculada a probabilidade $\mathrm{p}(\mathrm{A} \mid \mathrm{X})$, com $\mathrm{X}$ sendo o vetor composto pelos fatores de risco pertinentes: $\mathrm{X}=(\mathrm{x} 1, \mathrm{x} 2, \mathrm{x} 3 \ldots)$. Com o valor da probabilidade de ocorrência de um acidente, então, pode ser decidida a faixa de freqüência (ou probabilidade) que ele se encaixa. Então, como indicado no item 4.4.1, será determinado o nível de risco de ocorrência daquele acidente.

Para enquadrar as freqüências estimadas nas cinco faixas do modelo, será adotado o seguinte critério, coerente com o exposto na Tabela 4.4:

a) calcula-se: Freqüência_anual $=\mathrm{p}(\mathrm{A} \mid \mathrm{X}) * 2 * \mathrm{NVc} / 1000$, sendo NVc o número de viagens anuais do comboio (calculado no módulo custos);

b) se Freqüência_anual for menor ou igual a 1/20, então a frequiência será classificada como "muito rara";

c) se Frequiência_anual for menor ou igual a 1/10 e maior que 1/20, então a freqüência será classificada como "rara";

d) se Freqüência_anual for menor ou igual a $1 / 3$ e maior que $1 / 10$, então a freqüência será classificada como "ocasional";

e) se Freqüência_anual for menor que 10 e maior que 1/3, então a frequiência será classificada como "freqüente";

f) se Freqüência_anual for maior ou igual a 10, então a freqüência será classificada como "muito freqüente".

Não sendo possível o cálculo da probabilidade ou freqüência em algum tipo de acidente, será assumida a faixa de frequiência "default" indicada na Tabela 4.6 (se houver duas opções, será assumida a faixa de maior frequiência).

O modelo poderá, no futuro, em um estágio mais avançado, utilizar uma técnica estatística de simulação para melhor contemplar os cruzamentos ou interdependências 
entre os efeitos dos vários fatores de risco. Poderiam, por exemplo, ser utilizados os métodos de Monte Carlo, considerados adequados para modelagens de risco com grande número de variáveis (Rawson et al., 1998; The Glosten Associates, 2003).

\subsection{Módulo Ambiente}

Este módulo tem o objetivo de verificar as interferências ambientais importantes que podem ocorrer durante a passagem do comboio por determinado trecho da via. São quatro os pontos que deverão ser verificados pelo modelo:

○ se há a existência de áreas de preservação ambiental junto à hidrovia (informação que o usuário deve fornecer), estas áreas não deverão possuir terminais; o módulo ambiente verifica a coerência dos dados de entrada: se for informado um terminal em uma área de preservação, então será emitido um aviso de erro;

- possíveis efeitos de ondas geradas pela passagem do comboio sobre a estabilidade das margens do rio;

○ possíveis efeitos sobre a fauna e a flora dentro do rio devido aos aumentos de turbulência e de turbidez da água, em trechos rasos, ocasionado pela passagem do comboio (jatos dos propulsores e ondas do casco);

○ estimativa de quantidade da emissão de poluentes pelos motores do empurrador durante a passagem por cada trecho da hidrovia.

\subsubsection{Ondas geradas pelo comboio}

\subsubsection{Estimativa de altura de ondas}

Uma expressão de Knight, utilizada por Maynord (1999), pode estimar a altura máxima de ondas $\mathrm{H}_{\max }$ geradas pela passagem de comboios:

$$
H_{\text {max }}=\alpha_{1} \cdot S^{-0,33} \cdot\left(\frac{V}{\sqrt{g}}\right)^{2,67},
$$


onde S é a distância do ponto de interesse (a margem mais próxima, na maior parte dos casos) ao comboio (m); V é a velocidade da embarcação $(\mathrm{m} / \mathrm{s})$; g é a aceleração da gravidade $\left(\mathrm{m} / \mathrm{s}^{2}\right)$ e $\alpha_{1}$ é uma constante que assume um valor que depende do porte da embarcação. No caso, para os comboios de chatas, $\alpha_{1}=0,60$.

\subsubsection{Estimativa de força nas margens provocadas por ondas}

ITTC (2002-a) apresenta uma formulação de Norrbin para estimativa de força lateral sobre as margens, provocada por passagens de embarcações,. Para margens verticais: $Y_{V E R T}=\rho \cdot C_{B} \cdot B \cdot T \cdot V^{2} \cdot \eta_{O} \cdot\left[0,0925+0,372 \cdot\left(\frac{T}{h}\right)^{2}\right]$ e para margens inclinadas: $\quad Y=Y_{\text {vert }} \cdot\left[1+0,377 \cdot \eta_{o} \cdot k+19,53 \cdot \frac{V^{2}}{g \cdot L} \cdot k+0,0673 \cdot k^{3}-0,0988 \frac{T}{h} \cdot k^{3}\right]$, onde $\eta_{\mathrm{o}}$ é a razão entre a boca $\mathrm{B}$ e a distância entre a linha de centro da embarcação e a margem, k é a inclinação da margem $\left(\operatorname{tg}(\alpha)=\frac{1}{k}\right)$, h é a profundidade, $\mathrm{T}$ é o calado, L é o comprimento e V é a velocidade da embarcação.

\subsubsection{Critérios de avaliação da estabilidade de margens}

A obtenção dos efeitos das ondas geradas pelas embarcações, sobre as margens é um processo complexo que depende de informações do tipo de solo da margem, dos ângulos de taludes, se há alagamento em parte da margem e assim por diante.

Para o objetivo do presente modelo, para que não ocorram problemas de estabilidade das margens, é considerada suficiente uma das duas alternativas, indicadas a seguir.

Alternativa A: Obtenção das alturas de ondas em locais junto às margens e sua comparação com um valor de referência obtido em estudos específicos de avaliação de danos sofridos pelas margens de rios. Este valor de referência (altura máxima admissível de onda junto à margem) será um dado de entrada do modelo, obtido para aquele trecho em estudo do rio. 
Alternativa B: Obtenção dos valores de forças provocadas pelas ondas sobre as margens e comparação com um valor máximo admissível obtido em estudos de estabilidade de margens. Deste modo, para a avaliação dos efeitos da formação de ondas sobre as margens de determinado trecho de hidrovia, devem ser dados, além das características físicas e operacionais do comboio:

inclinação da margem, k (se não for fornecida, é assumido que a margem tem parede vertical),

distância entre a margem e a linha de centro longitudinal do comboio, dist,

força máxima admissível sobre as margens, Fmax, para que não ocorram problemas de estabilidade.

\subsubsection{Efeitos no fundo do rio}

A vazão de descarga de um hélice $\mathrm{Q}_{\mathrm{P}}$, com a embarcação em movimento, pode ser estimada pela seguinte expressão (Maynord, 2000b):

$$
Q_{P}=\frac{V_{a} \cdot \pi \cdot D^{2}}{8}+\sqrt{\frac{V_{a}^{2} \cdot \pi^{2} \cdot D^{4}}{64}+\frac{K_{T} \cdot n^{2} \cdot D^{6} \cdot \pi}{4 \cdot k}} \quad\left(\mathrm{~m}^{3} / \mathrm{s}\right)
$$

onde $\mathrm{V}_{\mathrm{a}}$ é a velocidade de avanço $(\mathrm{m} / \mathrm{s})$, D é o diâmetro do propulsor $(\mathrm{m}), \mathrm{K}_{\mathrm{T}}$ é o coeficiente de empuxo, n é o número de rotações do propulsor (rps) e k é um coeficiente que é igual a 2 para hélices abertos, e igual a 1 para hélices em dutos. QP é vazão de água devida ao propulsor.

A velocidade na saída do propulsor $\mathrm{V}_{\mathrm{P}}$ é calculada por: $V_{P}=\frac{Q_{P}}{\frac{\pi \cdot D^{2}}{4}}$.

Uma vez obtida a velocidade próxima à superfície, dada pela velocidade na saída do propulsor, é possível obter a velocidade da água próxima ao fundo do rio, com o comboio parado, utilizando a seguinte equação (Maynord, 2000b): 
$\frac{V_{\text {fundo }}}{V_{\text {sup erf }}}=0,34 \cdot\left(\frac{D}{H_{P}}\right)^{0,93} \cdot\left(\frac{x_{P}}{D}\right)^{0,24}$, onde $\mathrm{H}_{\mathrm{P}}$ é a distância do eixo do hélice ao fundo do canal e $\mathrm{X}_{\mathrm{P}}$ é distância longitudinal do hélice ao ponto de interesse.

As velocidades próximas ao fundo causam, a cada passagem de embarcações, uma nova suspensão de sedimentos em trechos rasos. A possibilidade da turbidez resultante causar danos importantes ao meio ambiente local deve ser avaliada em função de estudos específicos.

\subsubsection{Emissão de poluentes}

Para estimar as quantidades de poluentes emitidos pelos motores dos empurradores dos comboios, foram adotadas as relações que fornecem os valores limites de emissão de motores com potências maiores que $130 \mathrm{~kW}$ no rio Reno (CCNR, 2002):

$$
\begin{array}{ll}
\mathrm{CO} \text { (monóxido de carbono): } & 5,00 \mathrm{~g} / \mathrm{kW} / \mathrm{h} \\
\mathrm{HC} \text { (hidrocarboneto): } & 1,30 \mathrm{~g} / \mathrm{kW} / \mathrm{h} \\
\mathrm{NO}_{\mathrm{x}} \text { (óxido de nitrogênio): } & 45 \mathrm{x} \mathrm{n}^{-0,2} \mathrm{~g} / \mathrm{kW} / \mathrm{h}
\end{array}
$$

Os valores de potência média e os tempos de operação dos motores durante uma viagem redonda do comboio serão determinados pelas funções propulsão e custos.

\subsection{Módulo Águas Rasas}

Este módulo estima o efeito importante de navegação em águas rasas, de afundamento paralelo da embarcação ("squat”), em cada trecho da via, calculando o pé-de-piloto (distância entre o casco e o fundo do canal) resultante e comparando-o com os limites mínimos requeridos por normas de segurança da navegação. Este valor de pé-de-piloto também será utilizado para estimativa de riscos da passagem de comboio por trechos em águas rasas.

O módulo águas rasas não calcula os efeitos sobre o desempenho propulsivo e de manobras porque estes já são calculados em outras funções: 
a formulação de Howe, utilizada para estimativas de resistências ao avanço de comboios no módulo propulsão, já embute a correção dos efeitos de águas rasas;

a fixação de valores de coeficientes propulsivos dos comboios pelo modelo também já leva em consideração os efeitos das alterações de profundidades;

o módulo manobras também diferencia comportamentos de comboios em águas profundas e em águas rasas.

\section{Pé-de-piloto}

O pé-de-piloto resulta da estimativa de afundamento paralelo do casco ("squat") e será utilizado como uma verificação das condições de operação em trechos rasos da via. Se o pé-de-piloto c resultante para determinada velocidade for maior que o valor adotado como mínimo para o tipo de fundo do rio (Cmin), então a velocidade de cruzeiro no trecho deverá ser diminuída até que a condição $\mathbf{c} \geq \mathbf{C m i n}$ seja satisfeita.

A Tabela 4.7 apresenta os valores de pé-de-piloto indicados pela ABNT para canais, em função do tipo de fundo. Estes valores serão adotados como Cmin no modelo, em trechos da via onde podem ocorrer ondas. No caso de trechos não sujeitos a ondas, será adotada a recomendação da PIANC (1997), do pé-de-piloto ser de, no mínimo, 10\% do calado máximo da embarcação.

Tabela 4.7 - Pés-de-piloto mínimos adotados no modelo

\begin{tabular}{|l|c|}
\hline Tipo de fundo & Pé-de-piloto mínimo Cmin \\
\hline lodoso & $0,30 \mathrm{~m}$ \\
\hline arenoso & $0,50 \mathrm{~m}$ \\
\hline rochoso & $1,00 \mathrm{~m}$ \\
\hline
\end{tabular}

\section{Afundamento paralelo ("squat")}

Uma embarcação, com um casco de deslocamento, movendo-se a uma velocidade moderada em águas rasas, sofre um afundamento vertical ("squat"), como resultado de uma queda de pressão ao longo do seu casco (Norrbin, 1996). 
Existem várias formulações empíricas para aproximação da solução do problema de previsão de afundamento paralelo ("squat"), geralmente baseadas em dados experimentais. As principais formulações são dadas a seguir:

Barrass (1979): $\quad S=1 / 30 \cdot C_{\mathrm{b}} \cdot\left(A_{\mathrm{s}} /\left[A_{\mathrm{c}}-A_{\mathrm{s}}\right]\right)^{2 / 3} \cdot V_{\mathrm{k}}^{2.08}$

Eryuzlu (1994): $\quad S=\mathrm{h}^{2} / \mathrm{T} \cdot 0,298 \cdot\left[\mathrm{V} /(\mathrm{g} \cdot \mathrm{h})^{1 / 2}\right]^{2,289} \cdot(\mathrm{h} / \mathrm{T})^{-2,972} \cdot \mathrm{kb}$

sendo $\mathrm{kb}=3,1 /\left(\mathrm{W}_{\mathrm{o}} / \mathrm{B}\right)^{1 / 2}$ quando $\mathrm{W}_{\mathrm{o}} / \mathrm{B}<9,91 \mathrm{e}$

$\mathrm{kb}=1$ quando $\mathrm{W}_{\mathrm{o}} / \mathrm{B} \geq 9,61$

Millward (1990): $\quad S=(L / 100) \cdot\left(\left[15 \cdot C_{\mathrm{b}} \cdot(B / L)-0.55\right] \cdot F_{\mathrm{nh}}{ }^{2}\right) /\left(1-0.9 \cdot F_{\mathrm{nh}}\right)$

Norrbin (1996): $\quad S=(L / 100) \cdot\left([100 /(L / h)] \cdot\left[A_{\mathrm{s}} / A_{\mathrm{c}}\right] \cdot F_{\mathrm{nh}}{ }^{2}\right) /$

$$
\left(1-\left[A_{\mathrm{s}} / A_{\mathrm{c}}\right]-\left[\left(h \cdot W_{0}\right) / A_{\mathrm{c}}\right] \cdot{F_{\mathrm{nh}}}^{2}\right)
$$

Tuck (1966): $\quad S=L \cdot C_{\mathrm{s}} \cdot F_{\mathrm{nh}}^{2} /\left(1-F_{\mathrm{nh}}{ }^{2}\right)^{1 / 2}$

Onde:

$A_{\mathrm{c}}$ é a área da seção do canal $\left(m^{2}\right) ; A$ s é a área da seção imersa da embarcação $\left(m^{2}\right) ; B$ é a boca $(m) ; c$ é $o$ pé-de-piloto, h-T-S $(m) ; C_{\mathrm{b}}$ é o coeficiente de bloco; $F_{\mathrm{nh}}$ é o Número de Froude de profundidade $\left[=V /(g h)^{1 / 2}\right] ; h$ é a profundidade do canal $(\mathrm{m}) ; S$ é o afundamento paralelo ("squat") $(m) ; V$ é a velocidade da embarcação $(m / s) ; W_{\mathrm{o}}$ é a largura do canal $(m)$; $C_{\mathrm{s}}$ é o fator de forma de Tuck; $g$ é a aceleração da gravidade, $9,81 \mathrm{~m} / \mathrm{s}^{2} ; L$ é o comprimento na linha d'água $(\mathrm{m}) ; T$ é o calado $(\mathrm{m})$ e $V_{\mathrm{k}}$ é a velocidade da embarcação (nós).

O pé-de-piloto c, distância mínima que deve haver entre o fundo da embarcação e o fundo do rio, deve ser igual à profundidade do canal menos o calado e menos o afundamento paralelo ("squat"): $\mathrm{c}=\mathrm{h}-\mathrm{T}-\mathrm{S}$. 
As equações para estimativas do afundamento paralelo têm sido utilizadas para vários tipos e portes de embarcações. Dependendo do caso, uma delas se mostra mais apropriada, por reproduzir o fenômeno, verificado experimentalmente, em um tipo de embarcação. No modelo, após uma avaliação dos resultados das formulações disponíveis, optou-se por adotar a de Eryuzlu (1994), muito utilizada para previsão de "squat" de embarcações fluviais.

\subsection{Módulo Estreito}

O efeito de passagem em canais estreitos sobre o desempenho propulsivo de um comboio está incluído na formulação adotada de Howe.

Contudo, além do aumento de potência , se mantida a velocidade do comboio, podem ser provocados problemas de instabilidade de margens, devido à proximidade das paredes laterais e a ação de ondas geradas pela embarcação (módulo ambiente).

Podem, também, ser necessários desmembramentos do conjunto de chatas. O critério para verificação da necessidade e da quantidade de desmembramentos foi adotado a partir da formulação de canais de PIANC (1997): para canais de trânsito em mão única, será adotado o critério de largura do canal, ser maior ou igual a 2,2 vezes a boca da embarcação.

\subsection{Módulo Correntes}

Os seguintes valores de velocidades de correntes devem ser informados pelo usuário:

- correnteza média em cada trecho da via, que é somada ou subtraída da velocidade relativa da embarcação no módulo propulsão;

- velocidades de corrente paralelas e velocidades de corrente perpendiculares ao eixo do canal de navegação nas proximidades de pontes, utilizadas no módulo pontes. 
O módulo correntes tem apenas o objetivo de verificar a consistência dos dados informados e gerar, se for o caso, recomendações como diminuição de formação de comboios em determinado trecho crítico ou de aumento de potência instalada no empurrador.

\subsection{Módulo Ventos}

O módulo calcula as forças e momentos devidos a ventos em comboios de duas formas, dependendo do calado das chatas:

- com comboio composto por chatas vazias, são adotados os coeficientes obtidos em ensaios em túnel de vento, em três formações diferentes de comboios, por Brolsma et al. (1988);

- com comboios com carga total ou parcial nas chatas, o cálculo é baseado nos resultados apresentados em Isherwood (1973).

São obtidos os valores de forças Fx e Fy, respectivamente, as componentes longitudinal e lateral da força induzida pelo vento, e o momento de giro N ("yaw") também induzido pelo vento.

$$
\begin{aligned}
& F x=C x \cdot \frac{1}{2} \cdot \rho \cdot V_{R}^{2} \cdot A_{T} \\
& F y=C y \cdot \frac{1}{2} \cdot \rho \cdot V_{R}^{2} \cdot A_{L} \\
& N=C_{N} \cdot \frac{1}{2} \cdot \rho \cdot V_{R}^{2} \cdot A_{L} \cdot \text { Loa }
\end{aligned}
$$

sendo: $\rho$ a densidade do ar $=1,226 \mathrm{~kg} / \mathrm{m}^{3} ; \mathrm{V}_{\mathrm{R}}$ a velocidade do vento relativa ao comboio $(\mathrm{m} / \mathrm{s}) ; \mathrm{A}_{\mathrm{T}}$ a área transversal projetada exposta ao vento $\left(\mathrm{m}^{2}\right) ; \mathrm{A}_{\mathrm{L}}$ a área lateral projetada exposta ao vento $\left(\mathrm{m}^{2}\right)$; Loa o comprimento total do comboio (m).

Os coeficientes $\mathrm{Cx}, \mathrm{Cy}, \mathrm{C}_{\mathrm{N}}$ para um comboio com quatro chatas vazias (formação $2 \mathrm{x}$ 2) são apresentados na Figura 4.3 (Brolsma et al., 1988). 


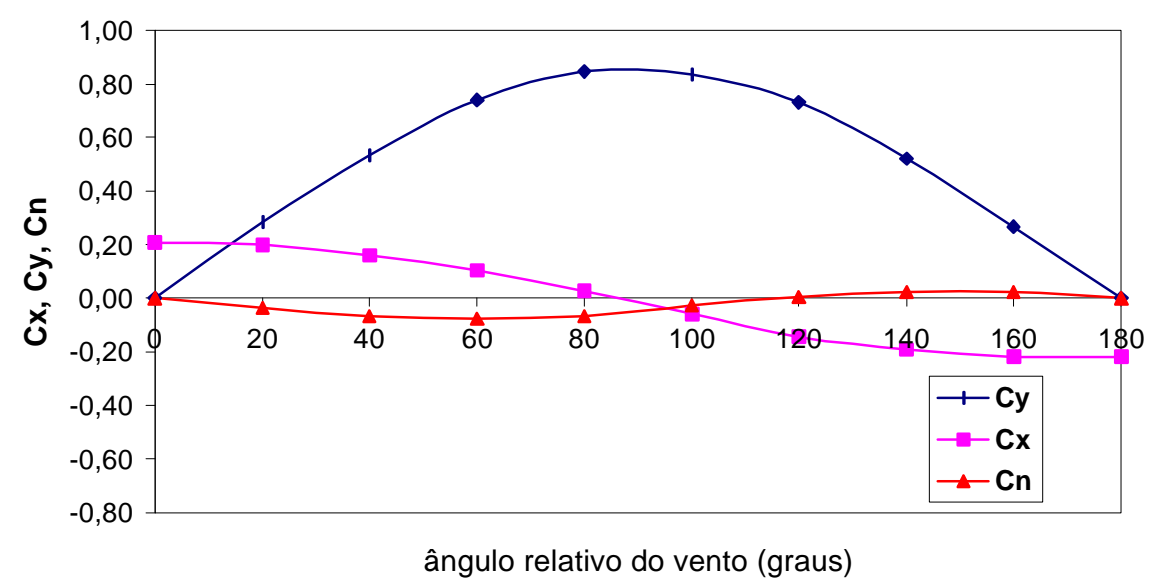

Figura 4.3 - Coeficientes para estimativa de forças e momento devidos a ventos em comboios de quatro chatas vazias - 2 × 2 (Brolsma et al. 1988)

Nas demais condições de carregamento das chatas, os coeficientes são obtidos com as regressões feitas por Isherwood (1973):

$$
\begin{aligned}
& C x=A_{0}+A_{1} \cdot \frac{2 \cdot A_{L}}{L o a^{2}}+A_{2} \cdot \frac{2 \cdot A_{T}}{B^{2}}+A_{3} \cdot \frac{L o a}{B}+A_{4} \cdot \frac{S}{L o a}+A_{5} \cdot \frac{C}{L o a} \\
& C y=B_{0}+B_{1} \cdot \frac{2 \cdot A_{L}}{L o a^{2}}+B_{2} \cdot \frac{2 \cdot A_{T}}{B^{2}}+B_{3} \cdot \frac{L o a}{B}+B_{4} \cdot \frac{S}{L o a}+B_{5} \cdot \frac{C}{L o a}+B_{6} \cdot \frac{A_{S S}}{A_{L}} \\
& C_{N}=C_{0}+C_{1} \cdot \frac{2 \cdot A_{L}}{L o a^{2}}+C_{2} \cdot \frac{2 \cdot A_{T}}{B^{2}}+C_{3} \cdot \frac{L o a}{B}+C_{4} \cdot \frac{S}{L o a}+C_{5} \cdot \frac{C}{L o a}
\end{aligned}
$$

onde: B é a boca do comboio (m); S é o perímetro da projeção lateral do comboio, excluindo a linha d'água e corpos afilados, como mastros (m); C é a distância da proa ao centróide da área projetada lateral $(\mathrm{m})$ e $\mathrm{A}_{\mathrm{SS}}$ é a área projetada lateral da superestrutura $\left(\mathrm{m}^{2}\right)$. As constantes $\mathrm{A}_{0}$ a $\mathrm{A}_{5}, \mathrm{~B}_{0}$ a $\mathrm{B}_{6}$ e $\mathrm{C}_{0}$ a $\mathrm{C}_{5}$ são tabuladas a partir de regressões múltiplas feitas com dados de ensaios de vários modelos de embarcações (Isherwood, 1973), em função do ângulo do vento com relação aos eixos de referência do comboio. 
Se o ângulo da direção do vento com relação ao eixo da embarcação não for fornecido, o modelo adota a condição mais crítica de vento, fixando o ângulo em 90 graus.

\subsection{Módulo Ondas}

Os dados de entrada deste módulo são estatísticos: a) o número de dias por ano em que há ondas em cada trecho da hidrovia; b) a altura média das ondas existentes nos trechos; c) direção predominante das ondas.

A estimativa de forças longitudinal $\mathrm{F}_{\mathrm{L} \xi}$ e transversal $\mathrm{F}_{\mathrm{T} \xi}$, assim como o momento resultante $M_{\xi}$ da ação de ondas pode ser feito utilizando as expressões (Insel \& Helvacioglu, 1996):

$$
\begin{aligned}
& F_{L \xi}=C_{L \xi} \cdot \rho \cdot g \cdot L \cdot\left(\bar{\xi}_{W}\right)_{\frac{1}{3}}^{2} ; \\
& F_{T \xi}=C_{T \xi} \cdot \rho \cdot g \cdot L \cdot\left(\bar{\xi}_{W}\right)_{\frac{1}{3}}^{2} ; \\
& M_{\xi}=C_{M \xi} \cdot \rho \cdot g \cdot L^{2} \cdot\left(\bar{\xi}_{W}\right)_{\frac{1}{3}}^{2},
\end{aligned}
$$

onde os coeficientes $C_{L \xi}, C_{T \xi}$ e $M_{\xi}$ são dados em função do ângulo da onda em relação à proa da embarcação. $\left(\bar{\xi}_{W}\right)_{\frac{1}{3}}$ é a altura significativa de onda.

Estes coeficientes são obtidos experimentalmente para algumas embarcações e podem ser utilizados para obtenção de valores aproximados de forças e momentos devidos a ondas.

Em caso de ondas fortes, deve ser recomendado cuidado especial com as amarras entre chatas e entre chatas e empurrador. Estas amarras são mais solicitadas em ondas, exigindo dimensionamentos e manutenções adequados. 


\subsection{Módulo Neblina}

O único dado de entrada deste módulo será o número de dias por ano em que ocorre problema de visibilidade na hidrovia. Aqui, devem ser incluídos períodos de neblinas e de chuvas intensas, em que a visibilidade é bastante prejudicada.

Este dado é utilizado para estimativas de riscos de acidentes, já que a falta de visibilidade pode se constituir em um fator de risco muito importante. Kite-Powell et al. (1998) apresenta exemplos de ocorrência de acidentes em quatro trechos de hidrovias americanas, indicando que o efeito de visibilidade ruim (adotada como menor que 2 quilômetros) influi no número de acidentes (Tabela 4.8). Fujii \& Mizuki (1998) indicam fatores de acréscimo de probabilidade de acidentes entre várias situações de falta de visibilidade (Tabela 4.9). O modelo adotará as faixas de visibilidade e os respectivos fatores utilizados na Tabela 4.9.

Tabela 4.8 - Dados de acidentes com comboios em quatro hidrovias (Kite-Powell et al., 1998), no período entre 1981 e 1995

\begin{tabular}{|l|c|c|c|c|}
\cline { 2 - 5 } \multicolumn{1}{c|}{} & New York & Tampa & Houston & $\begin{array}{l}\text { San } \\
\text { Francisco }\end{array}$ \\
\hline número de passagens (média anual) & 30.100 & 3.000 & 18.600 & 400 \\
\hline choques no fundo (1981 a 1995) & 73 & 81 & 327 & 13 \\
\hline colisões (1981 a 1995) & 305 & 68 & 376 & 45 \\
\hline choques no fundo por 1.000 passagens & 0,18 & 1,84 & 1,28 & 2,28 \\
\hline colisões por 1.000 passagens & 0,69 & 1,68 & 1,20 & 8,52 \\
\hline $\begin{array}{l}\text { acréscimos de choques no fundo com } \\
\text { visibilidade ruim }(*)\end{array}$ & $660 \%$ & $890 \%$ & $740 \%$ & $90 \%$ \\
\hline $\begin{array}{l}\text { acréscimos de colisões com visibilidade } \\
\text { ruim }(*)\end{array}$ & $630 \%$ & $810 \%$ & $600 \%$ & $160 \%$ \\
\hline
\end{tabular}

$\left(^{*}\right)$ - acréscimos percentuais de acidentes com visibilidade ruim $(<2 \mathrm{~km})$, comparados com acidentes com visibilidade boa $(\geq 2 \mathrm{~km})$ 
Se o nível de problemas por falta de visibilidade for considerado crítico, serão feitas recomendações de adoção de procedimentos operacionais especiais em passagens mais críticas (trechos em curva, passagem sob pontes ou canais estreitos, entradas em eclusas, etc.):

- diminuição de velocidades;

- atenção redobrada no passadiço (um tripulante a mais para ficar com atenção à vista, ao radar e à comunicação por rádio);

- em casos mais extremos (passagem sob ponte com vão reduzido), é recomendável aguardar a melhoria das condições, ancorados em local seguro.

Tabela 4.9 - Fatores de aumento de probabilidade de colisões em pontes em função das condições de visibilidade, definidas como porcentagens do tempo em que há visibilidade menor que 1 km (Fujii \& Mizuki, 1998)

\begin{tabular}{|l|c|c|}
\hline Frequiência de baixa visibilidade $(<\mathbf{1} \mathbf{~ k m})$ & Fator & Probabilidade \\
\hline Menor que 3\% & 1 & 0,0002 \\
\hline Entre 3\% e 10\% & 2 & 0,0004 \\
\hline Maior que 10\% e menor que 30\% & 4 & 0,0008 \\
\hline Maior que 30\% & 8 & 0,0016 \\
\hline
\end{tabular}

\subsection{Módulo Troncos}

O dado de entrada deste módulo é o número esperado de colisões de troncos por 1.000 passagens de embarcações em cada trecho da hidrovia.

Supõe-se que as ocorrências de troncos estejam uniformemente distribuídas ao longo de cada trecho considerado da hidrovia.

No caso de haver previsão de muitos eventos (fixado como referência, um número de choques no comboio, igual ou maior a dois por ano), devem ser propostas alternativas para diminuição das ocorrências e para minimização de danos, particularmente nos 
propulsores e lemes, muito expostos na popa dos empurradores. Por exemplo, pode ser avaliada a possibilidade de utilização de estruturas de proteção de propulsores e de lemes, como introduzida no comboio de pesquisas do Araguaia (Padovezi, 1997). As estruturas geralmente funcionam como proteção, mas apresentam o ônus de um aumento de resistência ao avanço em uma mesma velocidade da embarcação.

Outra alternativa seria a adaptação das linhas dos cascos do comboio, particularmente do empurrador, na fase inicial de projeto, para que haja uma menor probabilidade de colisões de troncos com a popa (Jukola \& Lindborg, 1999).

Uma possibilidade de ordem operacional é mapear os trechos e as épocas em que há um número maior de troncos flutuando nos rios e adotar procedimentos especiais como diminuir a velocidade de cruzeiro naqueles trechos ou instalar estruturas de proteção contra choques de troncos apenas nos períodos mais críticos.

A concentração de ocorrências de troncos e de outros objetos flutuando na água geralmente se dá no período de transição entre águas baixas (estiagem) e de cheias, em rios em corrente livre. À medida que os níveis dos rios vão subindo, a água leva os troncos de árvores caídas junto às margens. Os rios Madeira e Araguaia, por exemplo, apresentam grande variação anual de nível de água e margens sujeitas a instabilidades ao longo do tempo, resultando em uma tendência de concentração de troncos no período entre os meses de outubro e de janeiro.

Pelo exposto, o tratamento da questão de possibilidade de choques com troncos em lemes e propulsores, deve ser principalmente de caráter preventivo. Se houver a ocorrência, ela acarretará custos operacionais adicionais devido a atrasos da viagem e à manutenção. $\mathrm{O}$ módulo troncos calculará os custos de eventos de choques com troncos, estimando a probabilidade de ocorrência.

A forma de calcular os custos decorrentes de choques com troncos é a seguinte:

- a probabilidade de ocorrência de choques do comboio com troncos é um dado de entrada do modelo; 
a admite-se que um terço dos choques danifiquem os propulsores e os lemes do empurrador;

- os choques apenas com o casco (dois terços do total) terão um custo de $0,5 \%$ do preço atualizado do comboio, admitido para reparos no chapeamento;

- os custos relativos aos danos nos propulsores e nos lemes do empurrador serão computados em duas parcelas:

a) o custo dos reparos será igual a $15 \%$ do custo total da instalação propulsora (=cte $\_m a q \cdot M C R \cdot n M o t o r$, conforme o módulo custos);

b) será adicionado, ao tempo da viagem, o tempo parado do comboio de 5 dias para a realização de reparos (trocas de hélices e lemes).

\subsection{Módulo Pontes}

\subsubsection{Verificação da necessidade de desmembramentos}

A passagem sob pontes por comboios deve ser cercada de cuidados porque geralmente trata-se, dependendo do vão existente entre pilares, de um momento crítico da viagem. A ocorrência de um acidente com ponte geralmente traz consequiências graves, com grandes prejuízos econômicos e perda de vidas. Na análise de riscos, este tipo de acidente sempre será classificado como de alta gravidade potencial.

Para diminuir a probabilidade de colisões em pilares de pontes, é possível, e recomendável, que haja desmembramentos de grandes comboios para se efetuar a passagem sob pontes com vãos reduzidos. Em algumas hidrovias, como a TietêParaná e a Paraguai-Paraná, há exigências expressas de desmembramentos. O modelo permite que seja informado o número de desmembramentos em cada ponte da hidrovia. Se tal número não for informado, o módulo pontes faz uma verificação da necessidade de desmembramentos ou não. Esta verificação utiliza a definição de probabilidade geométrica de acidentes em pontes. 
A probabilidade geométrica PG é definida como a probabilidade condicional de uma embarcação bater em um pilar da ponte. Pode ser calculada a partir de uma distribuição normal, com o máximo na linha de centro do vão da ponte e assumindo, conforme sugerido pela AASHTO (1991), em que o desvio padrão $\sigma$ é igual ao comprimento da embarcação. Por definição, 68,3\% das colisões ocorrem entre $\sigma$ da média, 95,5\% ocorrem entre duas vezes o desvio padrão $(2 . \sigma)$ e 99,7 \% das colisões ocorrem entre três vezes o desvio padrão $(3 . \sigma)$.

A forma de obtenção da probabilidade geométrica de colisões de embarcações em pilares de pontes, com distribuição normal com média zero e desvio $\sigma$ igual ao comprimento L, sugerida pela AASHTO, apresenta um problema, que tornou-se evidente durante a aplicação para as pontes que passam sobre a hidrovia Tietê-Paraná. A adoção de $\sigma=\mathrm{L}$ é provavelmente baseada em dados estatísticos de uma quantidade de pontes com grandes vãos entre pilares. Contudo, para pontes com vãos reduzidos (menores que o comprimento das embarcações), como ocorre na hidrovia TietêParaná, a forma sugerida cria uma distorção, já que com o aumento do comprimento do comboio haveria uma redução da probabilidade geométrica de colisão, quando, na realidade, quanto maior o comprimento da embarcação maior a probabilidade de ocorrência de acidente.

Outro ponto importante é que não há sentido em aumentar os riscos de acidentes devido à possibilidade de cruzamentos de embarcações durante passagens sob pontes com vãos reduzidos. Nestas pontes, deve haver proibição explícita de quaisquer cruzamentos ou ultrapassagens e o centro do canal de navegação deve coincidir com o centro do vão entre pilares da ponte. Os atrasos decorrentes de possíveis esperas de embarcações para evitar cruzamentos sob pontes são irrelevantes, principalmente quando considerados os ganhos em segurança.

A fim de adaptar a estimativa da probabilidade geométrica da AASHTO às pontes de vãos reduzidos, foi adotado, no presente estudo, que o desvio da distribuição normal será igual ao vão da ponte, fixando o comprimento máximo do comboio em 139 m, equivalente a duas chatas em linha e um empurrador na hidrovia Tietê-Paraná. 
A probabilidade geométrica PG, calculada pelo módulo pontes, baseada em AASHTO (1991) e alterada no atual modelo, é definida na Figura 4.4. Esta alteração proposta foi baseada na análise dos dados de acidentes ocorridos nas pontes da hidrovia Tietê-Paraná no período de 1994 a 1999 (ANEXO C).

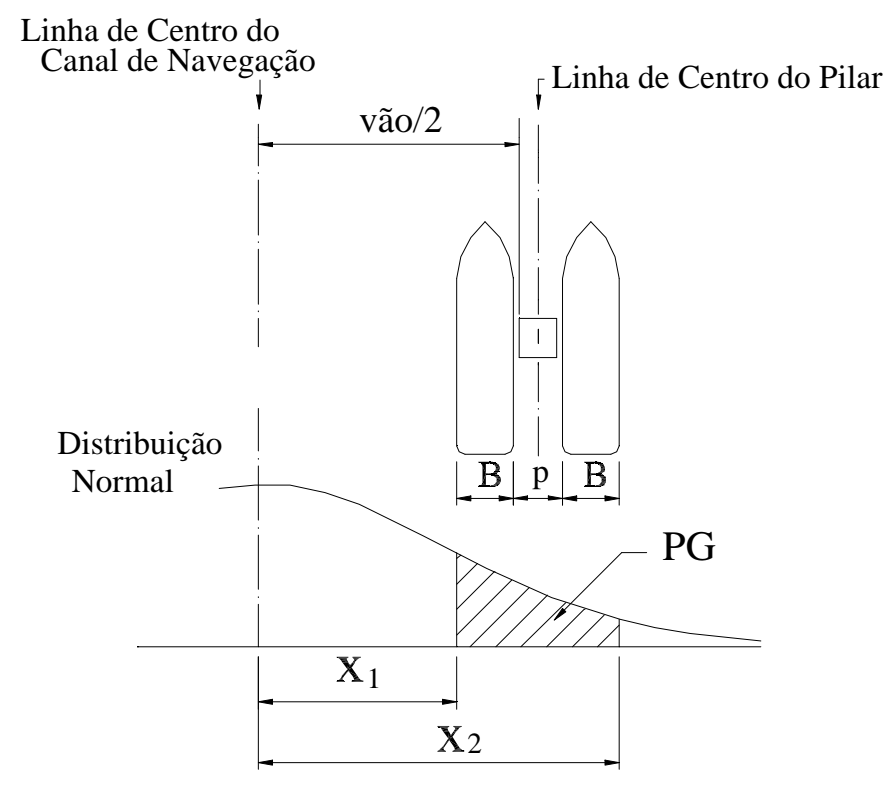

Figura 4.4 - Determinação da probabilidade geométrica de colisão em pontes (AASHTO, 1991), com adaptação para vãos reduzidos

O critério para verificação da necessidade de desmembramentos é o seguinte: enquanto PG for maior que 0,26 , tomado como referência a partir da análise dos dados de acidentes na hidrovia Tietê-Paraná (ANEXO C), haverá desmembramentos. No limite, se o valor de PG de referência não for alcançado, o processo terminará com o comboio formado por apenas uma chata (neste caso, o número de desmembramentos seria igual ao número de chatas do comboio). O valor de referência $\mathrm{PG}=0,26$ foi adotado considerando condições ambientais satisfatórias, ou seja, com baixas velocidades de ventos e com boa visibilidade.

\subsubsection{Probabilidade de ocorrência de acidentes em pontes}

AASHTO (1991) apresenta um método para estimativa de probabilidade de acidentes em pontes PA, baseado em estatísticas de acidentes em pontes nos Estados Unidos: 
$P A=B R \cdot R_{B} \cdot R_{C} \cdot R_{X C} \cdot R_{D}$, onde:

BR é a base de acidentes baseada em dados históricos; no caso de comboios fluviais, $\mathrm{BR}=1,2 \cdot 10^{-4}$, resultante da análise de acidentes ocorridos em hidrovias americanas;

$\mathrm{R}_{\mathrm{B}}$ é um fator de correção relativo à localização da ponte:

$R_{B}=1$ se a ponte está situada em uma região reta,

$R_{B}=\left[1+\theta / 90^{\circ}\right]$, para ponte localizada em região de transição (início ou final de uma curva do canal de navegação), sendo $\theta$ o ângulo da curva (graus),

$\mathrm{R}_{\mathrm{B}}=\left[1+\theta / 45^{\circ}\right]$, para ponte localizada em região de curva ;

$\mathrm{R}_{\mathrm{C}}$ é o fator de correção relativo à ação de correntes paralelas ao eixo da embarcação, sendo $R_{C}=[1+V c / 5,144]$, onde $V c$ é a velocidade de corrente em $\mathrm{m} / \mathrm{s}$;

$\mathrm{R}_{\mathrm{XC}}$ é a correção para velocidades de correntes perpendiculares ao eixo da embarcação: $\mathrm{R}_{\mathrm{XC}}=\left(1+\mathrm{V}_{\mathrm{XC}} / 0,5144\right)$, onde $\mathrm{V}_{\mathrm{XC}}$ é a velocidade de corrente perpendicular ao eixo da embarcação, em m/s;

$R_{D}$ é a correção em função da densidade do tráfego: $R_{D}=1$ para tráfego pouco intenso, $R_{D}=1,3$ para tráfego de média intensidade e $R_{D}=1,6$ para tráfego intenso.

A frequiência esperada anual de colisão da embarcação com pontes é calculada da seguinte maneira: Freqüência_anual $=\mathrm{PA} * \mathrm{PG} *$ NPano, sendo NPano o número de passagens do comboio sob uma ponte por ano.

O valor de freqüência anual poderá ser ainda amplificado por fatores de risco. No caso de pontes, os dados de acidentes no rio Tietê (ANEXO C) indicam que três fatores de risco podem amplificar a freqüência de acidentes: chatas trafegando vazias, ventos ou velocidades de corrente de altas intensidades e visibilidade ruim. Além disto, um fator poderia diminuir o risco de acidente em ponte: uma melhor qualidade de manobras da embarcação que pudesse fazer frente, por exemplo, às forças externas laterais que poderiam ser provocadas por ventos, ondas ou correntes. 
A formulação de estimativa de PA leva em consideração as velocidades de correntes no local da ponte. No caso de haver, no comboio, dispositivos de manobras que consigam compensar melhor as forças externas (propulsores azimutais e/ou "bow thrusters"), também não será levado em consideração o efeito de ventos ou de ondas.

Portanto, deverão ser calculados, dependendo do caso: p(colisão em pontes | chatas vazias); p(colisão em pontes | ventos fortes) e p(colisão em pontes | visibilidade ruim), seguindo procedimento exposto no módulo riscos.

\subsection{Módulo Eclusas e Canais}

O módulo tem dois objetivos:

a) verificar qual o maior comboio (formação de chatas) que pode passar por eclusagem ou por um canal estreito. No caso de serem necessários desmembramentos, deverão ser indicados quantos serão e qual o tempo adicional para a passagem do comboio pela eclusa ou pelo canal;

b) calcular os tempos necessários para eclusagens ou passagens de canal estreito, incluindo os tempos de espera. Esta parcela de tempo refere-se aos casos em que a via possui algum canal estreito, que não comporte cruzamento de embarcações, ou alguma eclusa.

\subsubsection{Desmembramentos}

A verificação das dimensões é feita em relação aos dados de comprimento, largura e calado máximo permitido em eclusas e aos dados de largura e profundidade, no caso de canais estreitos. Comparando-se as dimensões de eclusas e canais com as dimensões do comboio (empurrador + chatas), é verificada a necessidade de desmembramentos. Havendo desmembramentos, deverá ser minimizado o número necessário. Os tempos gastos em desmembramentos são informados ao módulo custos. 


\subsubsection{Tempos em eclusas e em canais}

Para a análise do tempo despendido em eclusas ou em canais que não comportam cruzamento de embarcações, em função da possibilidade de formação de filas, são consideradas as seguintes hipóteses:

- as chegadas das embarcações são regidas por processo de Poisson;

- existe apenas uma posição de atendimento, isto é, apenas uma embarcação é atendida por vez, ou em eclusa ou em navegação por canal;

- o módulo de distribuição do tempo de atendimento (eclusagem ou navegação no canal) é desconhecida; por outro lado, são conhecidos os valores da média $(1 / \mu)$ e do desvio padrão $(\sigma)$ do tempo de atendimento.

Com base nessas hipóteses, pode-se calcular o tempo de espera (TEsp) para atendimento e o tempo no sistema (TSist) (que corresponde à soma do tempo de espera com o tempo de atendimento) a partir da equação de Pollaczek-Khintchine (Novaes, 1975):

$$
\begin{aligned}
& \text { TEsp }=\frac{1}{\lambda}\left[\frac{\rho^{2}}{1-\rho}\right]\left[\frac{1+C^{2}(S)}{2}\right] \\
& \text { TSist }=\frac{1}{\mu}+\frac{1}{\lambda}\left[\frac{\rho^{2}}{1-\rho}\right]\left[\frac{1+C^{2}(S)}{2}\right]
\end{aligned}
$$

$\rho$ é o índice de congestionamento do sistema, dado por :

$$
\rho=\frac{\lambda}{\mu} \quad<1
$$

$C^{2}(S)$ é o coeficiente de variação do tempo de atendimento, calculado por:

$$
C^{2}(S)=\frac{\sigma}{1 / \mu}
$$

TSist fornece o tempo total despendido em uma eclusa ou canal.

Quando houver desmembramentos, estes serão levados em conta na obtenção de TSist e TEsp. 


\subsection{Módulo Curvas}

Em cada curva fechada, é calculada a sobre-largura que seria necessária para manter a velocidade de cruzeiro do comboio. Este resultado é comparado com a largura da via na curva.

A formulação para estimar a sobre-largura necessária na curva é dada por PIANC (1997):

$\Delta W=\frac{3,456 \cdot \phi \cdot V_{S}^{2} \cdot L^{2}}{R_{t} \cdot C_{c} \cdot S}$, onde $\Delta \mathrm{W}$ é a sobre-largura na curva; $\phi$ é o angulo da curva em graus; $\mathrm{V}_{\mathrm{S}}$ é velocidade da embarcação relativa ao fundo $(\mathrm{em} \mathrm{m} / \mathrm{s})$; L é o comprimento da embarcação(m); $\mathrm{R}_{\mathrm{t}}$ é o raio da curva $(\mathrm{m}) ; \mathrm{S}$ é distância de visada a partir da ponte de comando da embarcação $(m)$ e $C_{c}$ é um coeficiente em função da qualidade de manobra do comboio: $\mathrm{C}_{\mathrm{c}}=1$ para manobrabilidade ruim, $\mathrm{C}_{\mathrm{c}}=2$ para manobrabilidade boa e $\mathrm{C}_{\mathrm{c}}=3$ para manobrabilidade ótima.

A distância S mínima requerida geralmente está na faixa entre 2.000 e 2.500 metros. A classificação da manobrabilidade da embarcação para determinação de $C_{c}$ é feita com base no tipo de sistema de manobra informado, da seguinte maneira:

- $\quad$ ara sistemas convencionais, $\mathrm{C}_{\mathrm{c}}=1$;

- se há sistema auxiliar ("bow thruster" ou lemes de proa), $\mathrm{C}_{\mathrm{c}}=2$;

- $\quad$ se os propulsores são azimutais ou os lemes são de alta sustentação, $\mathrm{C}_{\mathrm{c}}=3$;

O módulo avalia a necessidade de haver desmembramentos do comboio para passagem de cada curva de raio de curvatura pequeno.

O módulo curvas, em conjunto com o módulo riscos, determina, ainda, a probabilidade de ocorrência de choques com as margens da via. 


\section{APLICAÇÃO DO MODELO - PROGRAMA ADAPTA}

A aplicação do modelo elaborado deve ser facilitada pelo desenvolvimento de um programa computacional que pode tornar automáticas as inúmeras verificações e análises propostas nas dezenas de módulos do modelo.

A linguagem de programação escolhida para a aplicação do modelo desenvolvido foi o MATLAB (versão 6). O programa, que recebeu o nome de ADAPTA, é detalhado neste Capítulo.

\subsection{Descrição do Programa}

A Figura 5.1 apresenta um esquema das entradas e saídas do programa, seguindo a concepção do modelo elaborado. São fornecidos os dados do comboio e da hidrovia, assim como as condições de operação e os valores de ventos e ondas esperados ao longo de um ano. O comboio percorre a via, em viagem redonda (ida e volta), e são quantificados os custos resultantes, o nível de segurança da navegação e o grau de interferência ambiental, extrapolando os resultados para o ano todo.

A Tabela 5.1 apresenta uma descrição dos dezessete módulos do modelo, representados pelas funções do programa ADAPTA. Além destas funções, são utilizadas mais sete funções auxiliares. A listagem das funções do programa é apresentada no Anexo E. 


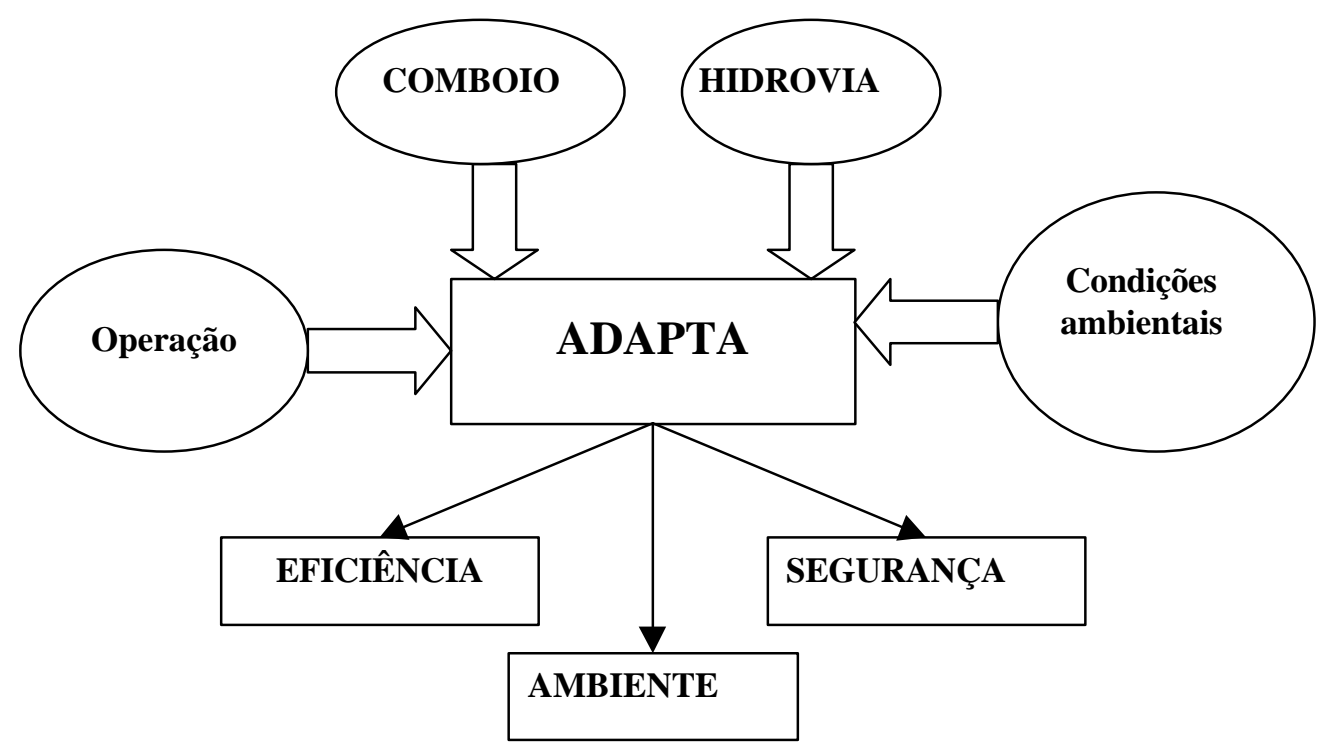

Figura 5.1 - Entradas e saídas do programa ADAPTA

As respostas da embarcação em cada trecho específico da via são obtidas da análise da integração entre o sistema de propulsão e o casco do comboio.

Para cada trecho específico da via (águas rasas, trecho estreito, curvas, pontes, eclusas, correntezas), há um módulo que calcula os parâmetros de desempenho do comboio, segundo modelo teórico-experimental escolhido e adaptado para cada caso (funções raso, estreito, curvas, pontes, eclusas_canais, correntes).

Os modelos foram validados com base em resultados de ensaios do IPT e de referências bibliográficas, particularmente no caso de propulsão, manobras, águas rasas, correntezas e passagens sob pontes.

Com relação aos itens da via considerados de caráter estocástico, como ocorrência de ventos, de ondas, de neblina e de troncos, há um tratamento específico nas funções correspondentes: ventos, ondas, neblina, troncos.

Os resultados da determinação dos graus de eficiência, de segurança à navegação e de interferência ambiental, são obtidos pelas funções custos, riscos e ambiente, respectivamente. Haverá registros do comportamento e do desempenho do comboio, trecho a trecho. 
Tabela 5.1 - Funções do programa ADAPTA

\begin{tabular}{|c|c|}
\hline Função & Descrição \\
\hline entra & $\begin{array}{l}\text { dados de entrada: características da via, do comboio, dos terminais, } \\
\text { da operação e opções de análise e de saída de dados }\end{array}$ \\
\hline raso & $\begin{array}{l}\text { efeitos de águas rasas sobre o comboio; avaliação do pé-de-piloto e } \\
\text { riscos de encalhes, interferências no fundo do rio }\end{array}$ \\
\hline estreito & $\begin{array}{l}\text { efeitos de restrição lateral sobre o comboio; riscos de choques nas } \\
\text { margens; interferências com margens }\end{array}$ \\
\hline curvas & $\begin{array}{l}\text { avaliação da necessidade de manobras extras e quantificação do } \\
\text { risco de choques nas margens }\end{array}$ \\
\hline correntes & efeitos sobre a propulsão e manobras; fator de risco de acidentes \\
\hline pontes & $\begin{array}{l}\text { quantificação do risco de acidentes, em função do vão e de } \\
\text { condições ambientais adversas; critério de desmembramentos }\end{array}$ \\
\hline $\begin{array}{l}\text { eclusas_ } \\
\text { canais }\end{array}$ & $\begin{array}{l}\text { estimativas de tempos despendidos nas eclusagens e em passagens } \\
\text { por canais estreitos; verificação de desmembramentos }\end{array}$ \\
\hline ondas & efeitos sobre propulsão e manobras / tratamento estocástico \\
\hline ventos & efeitos sobre manobras / tratamento estocástico \\
\hline neblina & efeitos sobre riscos de acidentes / tratamento estocástico \\
\hline tron & riscos de choques com lemes e hélices / tratamento estocástico \\
\hline manobras & $\begin{array}{l}\text { avaliação de desempenho em manobras, com diferentes dispositivos } \\
\text { de manobras; parada brusca de comboios fluviais }\end{array}$ \\
\hline propulsao & $\begin{array}{l}\text { modelo semi-empírico que estima a resistência de comboios nas } \\
\text { condições dadas da via (formulação de Howe, validadas por ensaios } \\
\text { em escala real e com modelos em escala reduzida) e coeficientes } \\
\text { propulsivos, calculando as potências e velocidades }\end{array}$ \\
\hline custos & $\begin{array}{l}\text { cálculo dos custos completos (fixos e variáveis) envolvidos em cada } \\
\text { viagem redonda do comboio, em função das características da via e } \\
\text { da embarcação. }\end{array}$ \\
\hline ambiente & $\begin{array}{l}\text { avaliação, nos trechos mais críticos, dos efeitos da passagem do } \\
\text { comboio, pela formação de ondas e pela esteira e jato dos } \\
\text { propulsores, sobre o ambiente (fundo do rio, estabilidade de } \\
\text { margens, aumento de turbidez) }\end{array}$ \\
\hline riscos & $\begin{array}{l}\text { estimativas de riscos de ocorrência de acidentes; quantificação do } \\
\text { nível de risco durante toda a viagem, considerando os fatores de } \\
\text { risco em cada tipo provável de acidente }\end{array}$ \\
\hline relato & $\begin{array}{l}\text { saída dos resultados das análises efetuadas; recomendações geradas } \\
\text { pelas funções; comparações com outros resultados }\end{array}$ \\
\hline
\end{tabular}


Nos trechos críticos, podem ser adotados procedimentos automáticos pelo programa ou podem ser geradas observações e recomendações consideradas importantes, segundo um critério desenvolvido no modelo. Por exemplo, em trechos em que os riscos de encalhes, ou de choques com o fundo do rio, são elevados, o programa adota soluções que podem minimizar o risco de acidentes ou de problemas ambientais. Tais soluções podem ser uma diminuição do calado operacional das chatas (neste caso, o programa admite tal redução e calcula seus efeitos sobre o desempenho do comboio) ou podem ser a realização de um certo volume de dragagens (neste caso, o programa gera uma observação sobre a questão, sugerindo que seja verificada a viabilidade tanto do ponto de vista econômico como ambiental).

O programa acumula os resultados de várias condições calculadas, podendo gerar gráficos e tabelas comparativos. Assim, as comparações entre os desempenhos de diferentes comboios (com variações de formas, de dimensões ou de equipamentos de manobras e de propulsão) poderão ser feitas de um modo automático.

No atual estágio do modelo, representado pelo programa ADAPTA, ainda não serão consideradas as possibilidades de ocorrências relacionadas a um grande volume de tráfego. Mesmo aquelas hidrovias brasileiras que se encontram em pleno funcionamento apresentam volume de tráfego relativamente baixo para que ocorram possíveis efeitos de um grande número de embarcações em trânsito. Assim, ocorrências como cruzamentos de embarcações em trechos de vias mais críticos ou filas para transposição de eclusas, podem ser evitadas por uma coordenação operacional adequada das embarcações em atividade.

\subsection{Encadeamento das Funções do Programa ADAPTA}

A Figura 5.2 apresenta o encadeamento de todas as funções do programa ADAPTA, as quais foram formuladas em linguagem MATLAB.

Inicialmente, a função entra organiza a entrada dos dados necessários à execução do programa. O modelo apresenta como entradas, os seguintes dados: 
- comboio (dimensões, equipamentos, calados em cada trecho);

- via (rotas, trechos específicos detalhados: profundidades, larguras de canais, raios de curvaturas, correntezas, tipos de fundo, pontes, eclusas);

- indicação de possibilidade de ocorrência e quantificação de ventos, ondas, neblina e troncos;

- dados operacionais (custos e taxas de embarque de cargas, número de tripulantes, etc.).

A função ADAPTA, a principal, coordena a sequiência de cálculos, da seguinte forma:

a o procedimento é repetido trecho a trecho da via, na ordem fornecida pelo usuário;

口 dependendo das características informadas de cada trecho, são chamadas as funções que introduzem os respectivos efeitos da relação via-comboio (funções raso, estreito, correntes, ventos, ondas, neblina, troncos );

- se existirem pontos críticos (curvas fechadas, pontes, eclusas, canais), então são chamadas as funções correspondentes;

- depois de acionar todas as funções representativas das características da via, são chamadas as funções relacionadas com o comboio: propulsão e manobras;

- ao final, o desempenho do comboio na via, em cada trecho específico, é estimado pelas funções de avaliação custos, riscos e ambiente.

A função relato gera as saídas do programa, na forma que o usuário escolheu ainda na função entra. 


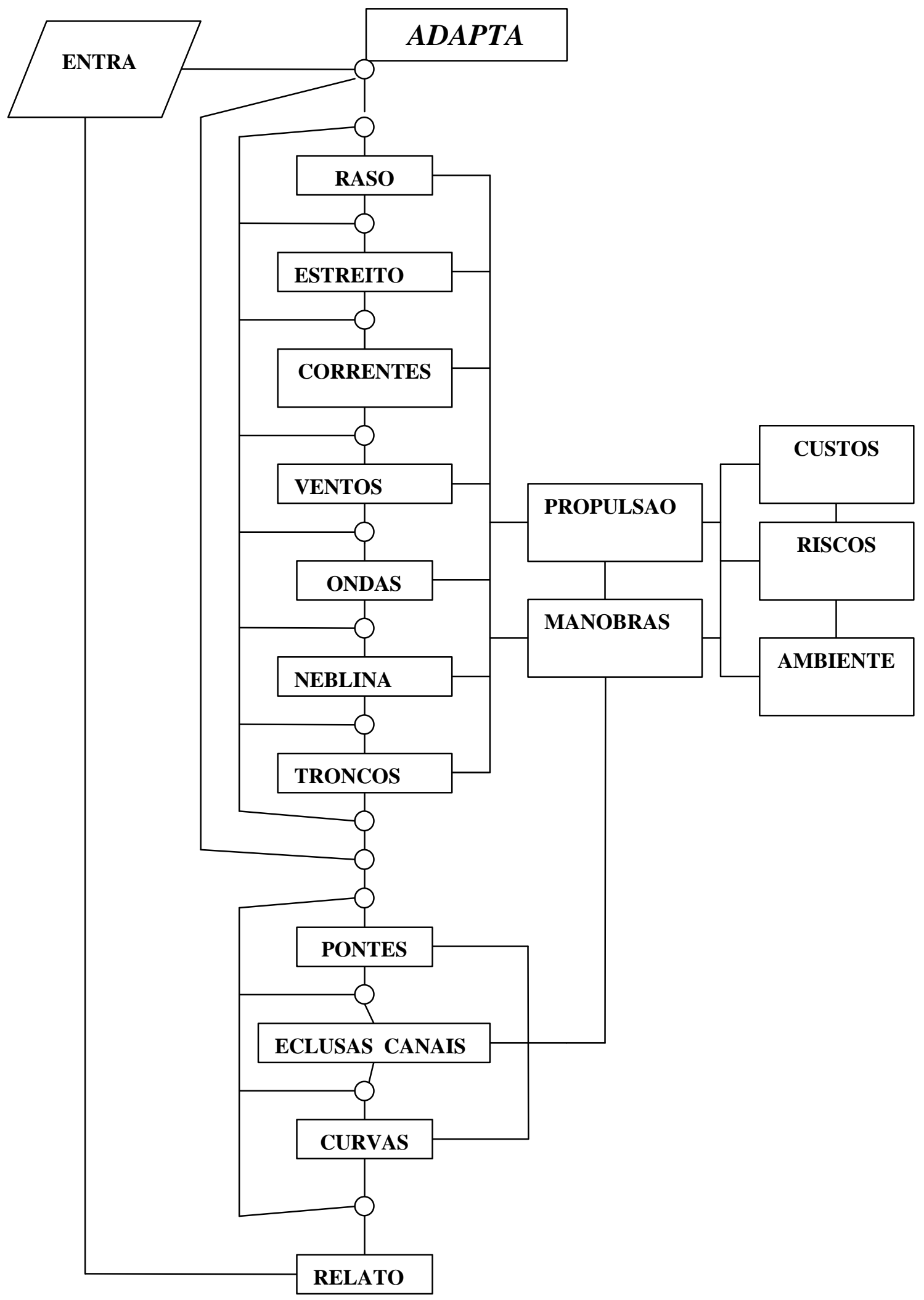

Figura 5.2 - Encadeamento das funções do programa ADAPTA 


\subsection{Descrição das Funções do Programa}

Todos os módulos do Capítulo 4 geraram as suas respectivas funções, de mesmo nome, no programa. Além destas 14 funções assim criadas, foram elaboradas mais três: uma para coordenação de todas as funções (função adapta), uma para entrada de dados e outra, para a saída de dados.

A seguir, serão descritas as funções de entrada e de saída do programa ADAPTA, assim como serão complementadas informações sobre alguns módulos expostos no Capítulo 4.

\subsubsection{Dados de entrada: função entra}

Esta função é um arquivo que deve editado pelo usuário com a introdução de todos os dados necessários à execução do Programa ADAPTA. Na própria função há os comentários necessários para identificação e entendimento de cada dado requerido.

A seqüência de entrada de dados é mostrada a seguir:

\section{a) números de elementos da via}

nTrecho - número de trechos em que a via será dividida (na ida);

nTerminal - número de terminais em que a embarcação pára (na ida e na volta);

nPontes - número de pontes que passam sobre a via;

nCurvas - número de curvas fechadas na via;

nEclusas - número de eclusas na via;

nCanais - número de canais estreitos na via.

\section{b) características do comboio}

Lemp - comprimento do empurrador (m);

Bemp - boca do empurrador (m); 
Temp - calado de operação do empurrador (m);

Pemp - pontal do empurrador (m);

CB_emp - coeficiente de bloco do empurrador;

Lchata - comprimento de uma chata (m);

Bchata - boca de uma chata (m);

Pchata - pontal das chatas (m);

Tmax - calado máximo das chatas (m);

CBchata - coeficiente de bloco das chatas;

nLinhas - número de linhas de chatas da formação do comboio;

nColunas - número de colunas de chatas da formação do comboio.

c) características do sistema propulsivo e de manobras

nMotor - número de motores/propulsores do empurrador;

MCR - potência instalada total no empurrador $(\mathrm{kW})$;

margem - fator de utilização do MCR máximo na operação;

efic_transm - eficiência de transmissão $\left(=\mathrm{P}_{\mathrm{D}} / \mathrm{P}_{\mathrm{B}}\right)$;

rotNom - rotação nominal do(s) motor(es) (rpm);

reducao $\quad$ - relação de redução de rotações $(1:$ reducao $)$;

prop_tipo - tipo dos propulsores $(1=$ aberto, $2=$ em duto, $3=$ azimutal, $4=$ misto);

serie - série de aproximação das características dos hélices: 'Troost' ou 'Kaplan';

KaDuto - KaDuto - geometria do hélice Kaplan e tipo de duto:

KaDuto 1: hélice Ka 4-70 em duto NSMB 19a ,

KaDuto 2: hélice Ka 4-70 em duto NSMB 37,

KaDuto 3: hélice Ka 4-55 em duto NSMB 19a ,

KaDuto 4: hélice Ka 3-65 em duto NSMB 19a ,

KaDuto 5: hélice Ka 5-75 em duto NSMB 19a ; 
Porc_Duto - porcentagem do duto que contribui com empuxo (obtém-se, descontando a parte embutida no casco);

diametro - diâmetro dos hélices (m);

AeAo - razão de área expandida dos hélices;

nPas - número de pás dos hélices;

P_D - razão passo / diâmetro dos hélices;

nLemes- número de lemes a re dos propulsores;

tipo_Leme - tipo dos lemes $(1$ = convencional / 2 = alto_lift $)$;

area_Leme - área de cada leme $\left(\mathrm{m}^{2}\right)$;

flancos - existem lemes de flancos ? ('sim' / 'não');

lemes_proa - existem lemes de proa ? ('sim' / 'não');

bow_thruster - existem "bow thrusters"? ('sim' / 'não');

d) vetores com as características da via

observação: Os números de elementos dos vetores estão relacionados com os números correspondentes dados no item a).

profundidade - profundidade média de cada trecho da via (m);

largura - largura média de cada trecho da via (m);

corrente - velocidade de corrente média em cada trecho $(\mathrm{m} / \mathrm{s})$, definida com relação ao trajeto de ida: (+) para descida e (-) para subida do rio;

solo - tipo de solo do fundo no trecho, conforme a seguir: 'lodos' ou 'areia' ou 'rocha';

nivelVentos - ocorrência de ventos em cada trecho (dia/ano);

nivelOndas - ocorrência de ondas em cada trecho (dia/ano);

nivelTroncos - ocorrência de acidentes com troncos em cada trecho (acidentes por 1000 passagens de embarcações);

nivelNeblina - ocorrência de neblina em cada trecho (dia/ano); 
posTerminal - vetor com as posições de cada terminal $(\mathrm{km})$. Os terminais são definidos na ida e na volta. Assim, se o comboio parar em um mesmo terminal tanto na ida como na volta, este terá 2 índices, entre 1 e "nTerminal". Lembrar que:

$$
\operatorname{posTerminal}(1)=\operatorname{pos} \text { Terminal }(\text { nTerminal })=0
$$

calado - calado das chatas na saída de cada terminal (m);

txcarga - taxa de carga de cada terminal $(\mathrm{t} / \mathrm{h})$;

txdescarga - taxa de descarga de cada terminal $(\mathrm{t} / \mathrm{h})$;

espera_carga - fração $(0,1$ a 1,0$)$ de tempo de carga/descarga em que o empurrador espera por chatas carregadas/vazias. Pode ocorrer das chatas já se encontrarem prontas, mas, neste caso, há necessidade de tempo para rearranjo do comboio, para abastecimentos, troca de tripulantes, etc.;

raioCurva - raio de curvatura de cada curva fechada - ponto crítico (m);

largCurva - largura média em cada curva fechada (m);

profCurva - profundidade média em cada curva fechada (m);

corrCurva - velocidade de corrente média em cada curva $(\mathrm{m} / \mathrm{s})$;

vaoPonte - vão horizontal da ponte junto ao canal de navegação (m);

largPilar - largura dos pilares da ponte (m);

largPonte - largura média do rio no local de cada ponte (m);

profPonte - profundidade média no local de cada ponte (m);

desmPonte - quantidade de desmembramentos obrigatórios na ponte;

VelCor_x - velocidade de corrente longitudinal na ponte $(\mathrm{m} / \mathrm{s})$;

VelCor_y - velocidade de corrente transversal na ponte $(\mathrm{m} / \mathrm{s})$;

extCanal - extensão de canal estreito $(\mathrm{km})$;

largCanal - largura média de cada canal (m);

profCanal - profundidade média em cada canal (m); 
atendCanal - tempo médio de atendimento em cada canal (hora);

desmCanal - quantidade de desmembramentos obrigatórios no canal

desvCanal - desvio padrão do tempo de atendimento no canal (hora);

largEclusa - largura máxima de embarcação dentro da eclusa (m);

compEclusa - comprimento máximo de embarcação dentro da eclusa (m);

calEclusa - calado máximo permitido em cada eclusa (m);

atendEclusa - tempo médio de atendimento em cada eclusa (hora);

desvEclusa - desvio padrão do tempo de atendimento na eclusa (hora);

\section{e) dados operacionais}

Ntrip - número de tripulantes do comboio;

NDM - número de dias em manutenção anual do comboio;

lambt - fluxo médio de chegada de embarcações em eclusas e canais nos dois sentidos (comboios/hora);

IDV - índice de disponibilidade da via (em porcentagem do tempo);

Salario_medio - salário médio dos tripulantes (em reais);

rancho_dia - custo da alimentação diária de cada tripulante;

CuOD - custo de litro de óleo Diesel (reais/litro);

custo_t_term - custo por tonelada de carga embarcada/desembarcada (reais).

\section{f) Opção de comparação de resultados}

nArq_compara - número de arquivos de dados de processamentos anteriores que se pretende comparar com os resultados atuais;

arquivos_compara - opção de comparar os resultados da análise dos dados fornecidos no presente momento com os resultados de processamentos anteriores. Para realizar as comparações basta fornecer os nArq_compara arquivos onde foram guardados os resultados anteriores; 
nome_saida_compara - nome do arquivo para guardar os dados da função compara.

\section{g) Arquivo de gravação dos resultados do programa}

nome_saida_relato - O usuário deverá fornecer o nome do arquivo em que serão gravados os resultados do programa.

\subsubsection{Saída de resultados: função relato}

Todos os resultados de todas as funções do programa, para todos os trechos da via, são apresentados nesta função, que deverá gravá-los, em formas de tabelas e de gráficos, no arquivo cujo nome é dado por "nome_saida_relato" da função entra.

Recomenda-se que o arquivo, cujo nome é dado em "nome_saida_relato", seja, depois, editado pelo usuário, a fim de obter a melhor formatação de saída dos resultados. No próprio arquivo constam instruções de como imprimir os resultados desejados.

Também na função relato será possível organizar as recomendações feitas ao longo do processamento do programa. Algumas funções (ambiente, riscos, propulsão, manobras, pontes, troncos, etc.) chegam em resultados que podem gerar recomendações, tanto de ordem operacional quanto física; neste caso, podendo sugerir intervenções na via ou melhorias de sistemas das embarcações.

Em princípio, podem ser feitas recomendações, entre outras, para intervenção em margens de determinados trechos da via, podem ser sugeridas diminuições de velocidade de operação em regiões mais críticas, assim como podem ser sugeridos incrementos na qualidade de manobra de comboio.

A partir da entrada, pela função entra, de nomes ("arquivos_compara") de "nArq_compara" arquivos de processamentos de casos anteriores, serão gerados tabelas e gráficos comparativos entre os casos escolhidos e os resultados do processamento atual. Os resultados desta função deverão ser salvos em um novo arquivo, com nome a ser fornecido pelo usuário ("nome_saida_compara" na função entra). 


\subsubsection{Funções Auxiliares}

Sete funções auxiliares foram elaboradas para serem utilizadas pelas funções principais. São elas:

- funções howe, btroost, kaplan, ktj2 e quedaempuxo, que são chamadas pela função propulsão;

- função desmembra, que é utilizada pela função eclusas_canais;

- função paradabrusca, chamada pela função manobras.

\subsubsection{Dados Complementares Utilizados por Algumas Funções}

\subsubsection{Função propulsao}

Os valores de coeficientes de esteiras que são utilizados no modelo para empurrador com popa (hélices e lemes) convencional estão indicados na Tabela 5.2. A Tabela 5.3 apresenta os coeficientes de redução da força propulsora. Os coeficientes são dados em função da profundidade e foram assumidos como constantes com a variação da velocidade do comboio.

Tabela 5.2 - Valores de coeficientes de esteira efetiva adotados - popa convencional

\begin{tabular}{|l|c|c|}
\hline \multirow{2}{*}{ Formação do comboio } & \multicolumn{2}{|c|}{$\omega$} \\
\cline { 2 - 3 } Uma chata (1 linha, 1 coluna) & $\mathrm{h} / \mathrm{T} \geq 2$ & $\mathrm{~h} / \mathrm{T}<2,0$ \\
\hline Duas chatas em linha (1 linha, 2 colunas) & 0,27 & 0,28 \\
\hline Duas chatas em paralelo (2 linhas, 1 coluna) & 0,25 & 0,29 \\
\hline Três chatas em linha (1 linha, 3 colunas) & 0,22 & 0,30 \\
\hline Quatro chatas (2 linhas, 2 colunas) & 0,25 & 0,32 \\
\hline Seis chatas (3 linhas, 2 colunas) & 0,33 & 0,33 \\
\hline Seis chatas (2 linhas, 3 colunas) & 0,40 & 0,40 \\
\hline Outras formações de chatas & 0,45 & 0,45 \\
\hline
\end{tabular}


Tabela 5.3 - Valores de coeficientes de redução da força propulsora adotados empurrador com popa convencional

\begin{tabular}{|l|c|c|}
\hline \multirow{2}{*}{ Formação do comboio } & \multicolumn{2}{|c|}{$\mathrm{t}$} \\
\cline { 2 - 3 } Uma chata (1 linha, 1 coluna) & $\mathrm{h} / \mathrm{T} \geq 2$ & $\mathrm{~h} / \mathrm{T}<2,0$ \\
\hline Duas chatas em linha (1 linha, 2 colunas) & 0,27 & 0,24 \\
\hline Duas chatas em paralelo (2 linhas, 1 coluna) & 0,20 & 0,24 \\
\hline Três chatas em linha (1 linha, 3 colunas) & 0,22 & 0,21 \\
\hline Quatro chatas (2 linhas, 2 colunas) & 0,18 & 0,20 \\
\hline Seis chatas (3 linhas, 2 colunas) & 0,33 & 0,30 \\
\hline Seis chatas (2 linhas, 3 colunas) & 0,30 & 0,30 \\
\hline Outras formações de chatas & 0,30 & 0,30 \\
\hline
\end{tabular}

O Anexo B mostra os resultados em que se baseiam os valores das Tabelas 5.2 e 5.3.

\subsubsection{Função custos}

Após a realização de uma série de levantamentos de dados relativos à construção e à operação de comboios fluviais, foram sugeridos valores para alguns dos parâmetros integrantes do método de cálculos de tarifas, conforme mostra a Tabela 5.4. Estes valores são passíveis de alterações ou atualizações futuras.

\section{Observacões quanto aos valores da Tabela 5.4:}

Os valores de estimativas de construção de embarcações foram obtidos admitindo $\mathrm{R} \$ 3,00$ por dólar.

MWM MOTORES (2000) indica um total de consumo de óleos lubrificantes da ordem de $0,5 \%$ do consumo total de óleo combustível em um motor de uma embarcação.

O custo de consumíveis diversos foi adotado como $0,3 \%$ do custo total de óleo combustível gasto. 
Tabela 5.4 - Valores assumidos pela função custos

\begin{tabular}{|c|c|c|}
\hline Símbolo & Descrição & Valor Adotado \\
\hline juros & Taxa de juros anual & $12 \%$ \\
\hline$n$ & Período de retorno em anos & 20 anos \\
\hline$V R c$ & $\begin{array}{l}\text { Valor residual da chata, ao final da vida útil (n } \\
\text { anos) = porcentagem do preço de uma chata nova }\end{array}$ & $20 \%$ \\
\hline VRemp & $\begin{array}{l}\text { Valor residual do empurrador, ao final da vida útil } \\
\text { (n anos) = porcentagem do preço do empurrador } \\
\text { novo }\end{array}$ & $20 \%$ \\
\hline Cmanut & $\begin{array}{l}\text { custo de manutenção de docagens e manutenção } \\
\text { (porcentagem do custo das embarcações novas) }\end{array}$ & $4 \%$ \\
\hline Cadm & $\begin{array}{l}\text { custo de administração (\% dos demais custos } \\
\text { fixos) }\end{array}$ & $10 \%$ \\
\hline Cespod & Consumo específico de óleo Diesel & 0,285 litros $/ \mathrm{kW} / \mathrm{h}$ \\
\hline Rol & $\begin{array}{l}\text { Relação volumétrica entre os consumos de óleo } \\
\text { lubrificante e de óleo Diesel }\end{array}$ & $0,5 \%$ \\
\hline Fcons & $\begin{array}{l}\text { Custo de consumíveis diversos (porcentagem do } \\
\text { custo de óleo Diesel) }\end{array}$ & $0,3 \%$ \\
\hline Fgerador & $\begin{array}{l}\text { consumo de óleo pelos geradores (porcentagem do } \\
\text { consumo de óleo pelos motores principais) }\end{array}$ & $8 \%$ \\
\hline horas_term & $\begin{array}{l}\text { número de horas por dia de funcionamento dos } \\
\text { terminais }\end{array}$ & 24 horas \\
\hline turno & número de horas de operação do comboio por dia & 24 horas \\
\hline encargos & encargos sociais sobre o salário da tripulação & $110 \%$ \\
\hline fracao_seg & $\begin{array}{l}\text { Custo de seguros - porcentagem do custo de } \\
\text { capital (anual) }\end{array}$ & $5 \%$ \\
\hline cte_maq & $\begin{array}{l}\text { custo de máquinas } \\
\text { para motores até } 1500 \mathrm{rpm} \\
\text { para motores com rotações > } 1500 \mathrm{rpm}\end{array}$ & $\begin{array}{l}3.400 \text { reais } / \mathrm{kW} \\
2.200 \text { reais } / \mathrm{kW}\end{array}$ \\
\hline
\end{tabular}

A adoção de $4 \%$ do custo da embarcação nova para estimativa de custo 
médio de manutenção e docagens foi feita a partir de indicações de Novaes (1975). Esta porcentagem é aumentada para 6\%, no caso de embarcações dotadas de propulsores azimutais.

O valor do coeficiente Kc, definido como coeficiente de peso, no caso de necessidade de estimativa de custo do casco de uma embarcação de aço, pode ser adotado como 0,12 toneladas-força por $\mathrm{m}^{3}$. Este coeficiente relaciona o volume (comprimento x boca x pontal) da embarcação com o peso em aço do seu casco. O valor adotado é resultante do levantamento desta relação para uma grande quantidade de cascos de chatas. Como se trata de um coeficiente aproximado, passível de atualização, recomenda-se sua utilização no caso de não haver um valor confiável de peso ou de preço da embarcação.

Um levantamento em catálogos e manuais de operação dos motores marítimos utilizados nas embarcações de empurradores fluviais no Brasil mostrou que é possível fixar um valor médio de consumo de combustível em função da potência e do tempo de operação, independentemente do fabricante e do tipo de motor.

Também foi possível fixar um valor médio de relação volumétrica entre os consumos de combustível e de lubrificantes, no mesmo período de tempo. Assim, a precisão da obtenção dos valores de consumos de combustíveis e lubrificantes fica apenas dependente da estimativa da potência média utilizada por uma determinada embarcação em uma determinada rota.

\subsubsection{Função ambiente}

As quantidades de emissões em uma viagem redonda do comboio serão calculadas, em gramas, por:

$$
\begin{aligned}
& \text { Quant_CO }=5,00 * \text { TVnavegando } * \text { Pot_media } *(1+\text { Fgerador }) \\
& \text { Quant_HC }=1,30 * \text { TVnavegando } * \text { Pot_media } *(1+\text { Fgerador }) ; \\
& \text { Quant_NOx }=45 * \mathrm{rpm} \_ \text {media }{ }^{-0,2} * \text { TVnavegando } * \text { Pot_media } *(1+\text { Fgerador })
\end{aligned}
$$


Quant_particulas $=0,54 *$ TVnavegando $*$ Pot_media $*(1+$ Fgerador $)$.

Sendo que: TVnavegando é o tempo de viagem redonda em que os motores da embarcação operam; Fgerador é a fração entre o consumo de óleo Diesel por geradores e pelos motores principais do empurrador; Pot_média é a potência média ponderada utilizada pelos motores principais do empurrador durante toda a viagem e rpm_media é o número de rotações médio dos motores durante toda a viagem.

Com a distância percorrida na viagem redonda, Dist_viagem, podem ser calculadas as respectivas quantidades de emissões por quilômetro de via:

Quant_CO_km = Quant_CO / Dist_viagem;

Quant_HC_km = Quant_HC / Dist_viagem;

Quant_NOx_km = Quant_NOx / Dist_viagem;

Quant_particulas_km = Quant_particulas / Dist_viagem.

\subsubsection{Função ventos}

A seguir, são apresentados os dados utilizados na função ventos, conforme definido no modelo correspondente mostrado na Capítulo 4.

Para a utilização das formulações de Isherwood (1972) na estimativa de forças e momentos de ventos em comboios carregados, serão adotados os seguintes valores, adaptados de navios tanque carregados:

$\frac{2 \cdot A_{L}}{L^{2} a^{2}}=0,100 ; \frac{2 \cdot A_{T}}{B^{2}}=1,59 ; \frac{S}{L o a}=1,33 ; \frac{C}{L o a}=0,568 ; \frac{A_{S S}}{A_{L}}=0,211$ onde:

B é a boca do comboio (m); S é o perímetro da projeção lateral do comboio, excluindo a linha d'água e corpos afilados, como mastros (m); C é a distância da proa ao centróide da área projetada lateral $(\mathrm{m})$ e $\mathrm{A}_{\mathrm{SS}}$ é a área projetada lateral da superestrutura $\left(\mathrm{m}^{2}\right)$.

A Tabela 5.5 apresenta os coeficientes que serão utilizados no programa para estimativa de forças em comboios de chatas vazias. 
Tabela 5.5 - Coeficientes obtidos em túnel de vento com modelo de comboio com chatas vazias (Brolsma et al., 1988)

\begin{tabular}{|c|c|c|c|c|c|c|c|c|c|}
\hline & \multicolumn{3}{|c|}{ Comboio 2 x 2 } & \multicolumn{3}{c|}{ Comboio 1 x 2 } & \multicolumn{3}{c|}{ Comboio 2 x 3} \\
\hline $\boldsymbol{\gamma}$ (graus) & $\mathbf{C x}$ & $\mathbf{C y}$ & $\mathbf{C n}$ & $\mathbf{C x}$ & $\mathbf{C y}$ & $\mathbf{C n}$ & $\mathbf{C x}$ & $\mathbf{C y}$ & $\mathbf{C n}$ \\
\hline 0 & 0,2090 & 0,0000 & 0,0000 & 0,1235 & 0,0000 & 0,0000 & 0,3230 & 0,0000 & 0,0000 \\
\hline 20 & 0,1995 & 0,2850 & $-0,0352$ & 0,1188 & 0,2860 & $-0,4275$ & 0,3040 & 0,2755 & $-0,3420$ \\
\hline 40 & 0,1615 & 0,5320 & $-0,0675$ & 0,1045 & 0,5700 & $-0,7030$ & 0,2299 & 0,5700 & $-0,6365$ \\
\hline 60 & 0,1045 & 0,7410 & $-0,0764$ & 0,0608 & 0,9025 & $-0,7660$ & 0,1425 & 0,7695 & $-0,7600$ \\
\hline 80 & 0,0285 & 0,8455 & $-0,0675$ & 0,0190 & 1,0735 & $-0,6750$ & 0,0475 & 0,8455 & $-0,6555$ \\
\hline 100 & $-0,0600$ & 0,8360 & $-0,0266$ & $-0,0190$ & 1,0545 & $-0,1045$ & $-0,0570$ & 0,8360 & $-0,2565$ \\
\hline 120 & $-0,1425$ & 0,7315 & 0,0048 & $-0,0798$ & 0,8645 & 0,0000 & $-0,1615$ & 0,7505 & 0,1045 \\
\hline 140 & $-0,1900$ & 0,5225 & 0,0232 & $-0,1064$ & 0,5225 & 0,0285 & $-0,2565$ & 0,5795 & 0,4465 \\
\hline 160 & $-0,2185$ & 0,2660 & 0,0238 & $-0,1330$ & 0,2185 & 0,1520 & $-0,3135$ & 0,3040 & 0,3135 \\
\hline 180 & $-0,2185$ & 0,0000 & 0,0000 & $-0,1235$ & 0,0000 & 0,0000 & $-0,3040$ & 0,0000 & 0,0000 \\
\hline
\end{tabular}

Sendo que $\gamma$ é o ângulo relativo do vento com relação à embarcação, a partir da proa (se não for fornecido, $\gamma$ será adotado como $90^{\circ}$ ).

\subsubsection{Função pontes}

Na Figura 5.3, é mostrado o resultado do cálculo da probabilidade geométrica PG de colisão de comboio em pilar de uma ponte que passa sobre o rio Tietê, obtida por função específica do programa MATLAB. A valor obtido, na forma definida no modelo, foi $\mathrm{PG}=0,176$ para um comboio de duas chatas em linha passando sob a ponte da rodovia SP-461 sobre o rio Tietê (vão atual de $77 \mathrm{~m}$ ).

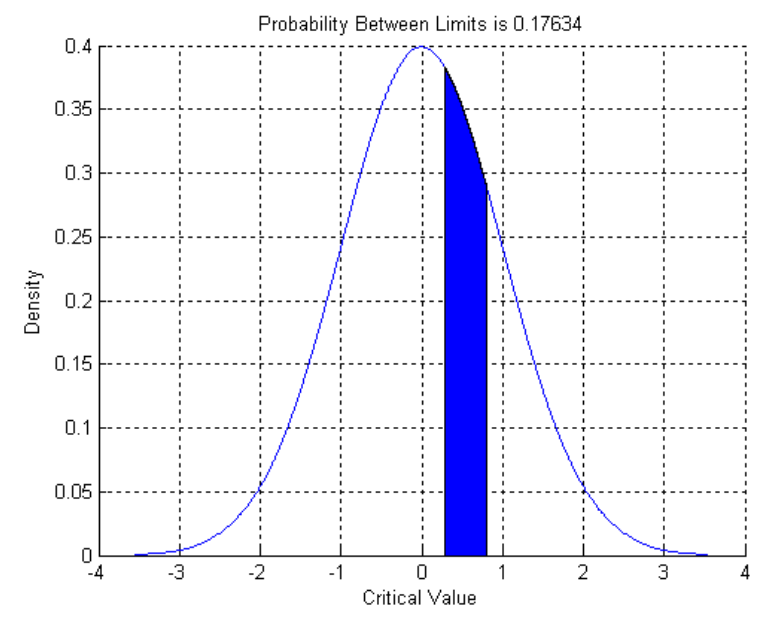

Figura 5.3 - Estimativa de probabilidade geométrica PG de acidentes de um comboio de duas chatas em linha, passando sob a ponte da rodovia SP-461 sobre o rio Tietê 


\section{APLICAÇÃO DO MODELO}

Nos Capítulos anteriores, foi apresentado o desenvolvimento de um modelo de auxílio ao projeto de comboios fluviais, com o objetivo de minimizar custos de transportes, mas interagindo com as restrições advindas da necessidade de manter determinado nível de segurança da navegação e um pequeno grau de interferência ambiental.

No presente Capítulo, este modelo será aplicado a dois casos de transportes em hidrovias brasileiras (Tietê-Paraná e Araguaia), a fim de verificar a eficácia e as implicações dos procedimentos propostos para o projeto integrado de comboios adaptados à via navegável.

\subsection{Hidrovia Tietê-Paraná}

\subsubsection{Descrição do Transporte}

O modelo foi aplicado para o caso de projeto de comboios de transporte de soja entre os terminais de São Simão (GO) e Pederneiras (SP) pela hidrovia Tietê-Paraná. O transporte de soja é o que apresenta maior volume de cargas nesta hidrovia, quando não são consideradas as cargas de percursos menores como cana-de-açúcar e areia.

Em Pederneiras, em terminais apropriados, a carga é desembarcada das chatas e armazenada para, logo em seguida, ser embarcada em vagões para continuar viagem, por ferrovia, até o porto de Santos (SP). A quantidade de carga disponível é grande o 
suficiente para não ocorrer espera por cargas em terminais; ou seja, admite-se que as cargas estão sempre nos terminais à disposição dos sistemas de embarque. Com grande quantidade de carga à disposição, os calados de carregamentos das chatas serão sempre os maiores possíveis, submetidos às restrições objetivas da via e, pela aplicação do modelo atual, também submetidos a uma avaliação de níveis de riscos em diferentes situações de navegação.

Atualmente, não há carga de retorno, ou seja, de Pederneiras a São Simão, as chatas trafegam completamente vazias, com seu deslocamento leve. Em princípio, o lastreamento de chatas tem sido descartado por razões de ordens técnica (não há preparo das chatas para receberem lastro), econômica (o lastreamento aumentaria os custos operacionais) e ambiental (a água de lastro pode se constituir em um veículo de transporte de organismos de um local para outro).

Apesar do rio Tietê desaguar no rio Paraná, a falta de eclusa na barragem de Ilha Solteira faz com que a ligação entre os dois rios seja feita pelo canal de Pereira Barreto e pelo rio São José dos Dourados. No trajeto entre Pederneiras e São Simão, de 640 km, são percorridas as seguintes distâncias, em quatro rios:

a rio Tietê, de Pederneiras ao canal de Pereira Barreto 369 km;

u canal de Pereira Barreto: 9 km;

rio São José dos Dourados, do canal de Pereira Barreto até o rio Paraná: 36 km;

rio Paraná, da foz do rio São José dos Dourados à foz do rio Paranaíba: 55 km;

- rio Paranaíba, de sua foz ao porto de São Simão: 171 km.

As principais restrições da hidrovia Tietê-Paraná são as passagens sob pontes, com um histórico de acidentes no período entre 1994 e 1999. Os pilares não suportam qualquer choque e os vãos são relativamente reduzidos para passagens, com a segurança adequada, de comboios.

Atualmente, na hidrovia Tietê-Paraná, são utilizados comboios com quatro chatas, na formação duas a duas, havendo operações de desmembramentos nas entradas de eclusas, cujas dimensões só permitem duas chatas por vez, e nas passagens sob 
pontes. O desmembramento, expediente que torna possível a utilização de comboios de chatas maiores que aqueles suportados por determinada restrição da via, será objeto de verificações neste exemplo de aplicações.

Os dados detalhados de entrada do programa ADAPTA, desenvolvido para a aplicação do modelo proposto no presente estudo, são apresentados no Anexo D.

O percurso, de $640 \mathrm{~km}$ entre São Simão e Pederneiras, foi dividido em 17 trechos com características diferenciadas, principalmente com relação à profundidade média. Foram informados os dados de 9 pontes, de 5 eclusas e de 3 canais artificiais, que estão dentro do percurso escolhido. Os terminais informados são localizados nas extremidades do percurso: em São Simão, onde há o carregamento de soja, e em Pederneiras, onde é feito o descarregamento.

\subsubsection{Investigação das Alternativas de Embarcações e de Procedimentos Operacionais}

De acordo com o modelo elaborado, serão objeto de investigação, os seguintes grupos de alternativas de projeto e de operação: dimensões e formações dos comboios, calados das chatas, sistemas de manobras, margem de potência e velocidades de operação. A Tabela 6.1 apresenta as alternativas que serão avaliadas.

Tabela 6.1 - Alternativas que serão analisadas

\begin{tabular}{|l|l|}
\hline \multicolumn{1}{|c|}{ item } & \multicolumn{1}{c|}{ alternativas } \\
\hline $\begin{array}{l}\text { A. Dimensões e formação do } \\
\text { comboio }\end{array}$ & $\begin{array}{l}\text { A.1. comboios com chatas de diferentes comprimentos (3 x } \\
40 \mathrm{~m} \text { e 2 x 60m) } \\
\text { A.2. comboio de duas chatas, que não necessite de } \\
\text { desmembramentos } \\
\text { A.3. comboio com quatro chatas }\end{array}$ \\
\hline B. Calados de operação & $\begin{array}{l}\text { B.1. verificação de calados máximos (2,5 m e 2,7 m) } \\
\text { B.2. Estudo de riscos de trânsito de chatas vazias }\end{array}$ \\
\hline C. Margem de potência & $\begin{array}{l}\text { C.1. Verificação de margens de potências instaladas } \\
\text { (custos x riscos): de 10\% e 20\% }\end{array}$ \\
\hline D. Qualidade de manobra & $\begin{array}{l}\text { D.1. sistema convencional } \\
\text { D.2. lemes com flaps } \\
\text { D.3. propulsores azimutais }\end{array}$ \\
\hline E. Velocidades de operação & E.1. Variações de velocidades de operação \\
\hline
\end{tabular}




\subsubsection{Dimensões e formações de comboios}

A hidrovia Tietê-Paraná, por possuir eclusas de determinadas dimensões padronizadas de câmaras, praticamente obriga a adoção de dimensões de chatas e empurradores atualmente já utilizadas. Os atuais comboios ocupam toda a câmara da eclusa com um empurrador (comprimento de cerca de $19 \mathrm{~m}$ ) e duas chatas (de comprimento de $60 \mathrm{~m}$ cada e 11 metros de boca). Dimensões menores que estas, levam à perda da capacidade de transporte. Uma maior subdivisão, por exemplo, três chatas de $40 \mathrm{~m}$ de comprimento, ao invés de duas de $60 \mathrm{~m}$, aumenta o custo de construção e diminuem a carga útil. Supondo que se mantenham as bocas, as chatas de menores comprimentos teriam coeficiente de blocos menores, porque perderiam, praticamente, comprimento à meia nau. Uma comparação de duas opções é mostrada na Tabela 6.2.

Tabela 6.2 - Comparações de opções de tamanhos de chatas na hidrovia Tietê-Paraná ( 3 chatas de $40 \mathrm{~m}$ versus 2 chatas de $60 \mathrm{~m}$ )

\begin{tabular}{|l|c|c|}
\hline \multirow{2}{*}{ valores calculados } & \multicolumn{2}{|c|}{ dimensões de chatas } \\
\cline { 2 - 3 } & 3 chatas de 40 m & 2 chatas de 60 m \\
\hline Comprimento de cada chata (m) & 40 & 60 \\
\hline Boca da chata (m) & 11 & 11 \\
\hline Calado carregado das chatas (m) & 2,5 & 2,5 \\
\hline Coeficiente de bloco & 0,80 & 0,90 \\
\hline Custo de construção das chatas (R\$) & $\sim \mathrm{R} \$ 3.000 .000,00$ & $\sim \mathrm{R} \$ 3.000 .000,00$ \\
\hline Carga útil do comboio (t) & 2.170 & 2.490 \\
\hline
\end{tabular}

Chatas de comprimentos maiores, ou de $120 \mathrm{~m}$ de comprimento para continuar aproveitando todo o espaço de cada eclusagem, tendem a ter problemas estruturais.

Com relação à formação dos comboios, as opções são: navegar com comboio de duas chatas, não necessitando desmembramentos ou navegar com quatro chatas, desmembrando em eclusas e em passagens de pontes e canais estreitos. A Tabela 6.3 
mostra os resultados das comparações feitas pelo programa ADAPTA. Em princípio, foram calculados os custos para tempos de espera total nos terminais, sem considerar chatas carregadas ou descarregadas aguardando o comboio.

Tabela 6.3 - Comparações de opções de formação de comboios na hidrovia TietêParaná ( 2 chatas em linha ou quatro chatas 2 x 2). Mesma potência instalada, calados de $2,5 \mathrm{~m}, 85 \%$ de disponibilidade da via

\begin{tabular}{|l|c|c|}
\hline \multirow{2}{*}{ valores calculados } & \multicolumn{2}{|c|}{ formação de comboio } \\
\cline { 2 - 3 } & 2 chatas em linha & 4 chatas 2 x 2 \\
\hline Preço atualizado do comboio (R\$) & 5.286 .400 & 8.800 .800 \\
\hline Tempo de ciclo (uma viagem) (dias) & 5,1 & 8,5 \\
\hline Número de viagens por ano & 58,4 & 35,2 \\
\hline Capacidade de carga por viagem (t) & 2.360 & 4.720 \\
\hline Carga transportada por ano (t) & 137.824 & 166.144 \\
\hline Custo total anual (R\$) & 2.535 .800 & 3.192 .200 \\
\hline Custo por tonelada (R\$ / t) & 18,38 & 19,20 \\
\hline Custo por tonelada por km (R/t.km) & 0,0287 & 0,0299 \\
\hline
\end{tabular}

Dos resultados da Tabela 6.3 pode ser verificado que as restrições que exigem desmembramentos na hidrovia Tietê-Paraná (cinco eclusas e oito pontes), atualmente, tendem a aumentar muito o tempo neste tipo de manobras, resultando em custos por tonelada transportada maiores para a opção de utilização de quatro chatas.

Ao mesmo tempo, com relação à segurança, a opção de transporte com quatro chatas aumenta os riscos de acidentes, como explicado a seguir.

a) A quantidade de desmembramentos em pontes é elevada, o que resulta em um grande número de manobras adicionais, elevando riscos de acidentes ou incidentes devido à faina maior da tripulação. 
b) Passagens consecutivas sob pontes ou em canais estreitos, devido aos desmembramentos, aumentam a probabilidade de ocorrência de acidentes. No caso, o comboio de quatro chatas levará a 4 passagens com comboio desmembrado por ponte da hidrovia (duas na ida e duas na volta), não considerando a passagem do empurrador escoteiro. Deste modo, o comboio de quatro chatas fará com que se passe sob a ponte 141 vezes por ano por ponte (duas chatas por vez), enquanto que o comboio de duas chatas passará 117 vezes por ponte por ano. Como a probabilidade de acidentes é proporcional ao número de passagens, o comboio de quatro chatas, mesmo desmembrando em duas, tem uma probabilidade de acidentes em pontes $20 \%$ maior do que o comboio de duas chatas. As probabilidades básicas (ou os riscos por passagem) são as mesmas porque os comboios que trafegam sob as pontes têm as mesmas dimensões e o mesmo número de chatas. As opções diferem, contudo, na exposição ao risco.

c) Com relação a possíveis interferências ambientais, se os desmembramentos ocorrem em trechos rasos, como acontece nos casos das pontes das rodovias SP-461 e BR-153, as interferências são maiores devido ao grande número de manobras para trafegar de um lado a outro com parte das chatas. A resuspensão de sedimentos é mantida por mais tempo porque as manobras se repetem em um curto espaço de tempo. Manobras realizadas próximas às margens também colocarão em risco a estabilidade de margens, se estas estiverem desprotegidas. Assim, pode ser afirmado que, do ponto de vista ambiental, pelo menos nas pontes localizadas em trechos rasos (SP-461 e BR153), os problemas com comboios com quatro chatas são muito maiores que com os comboios de duas chatas, os quais não requerem manobras extras nos locais mais sujeitos a problemas em margens e em fundos de rios. O programa ADAPTA quantificou 27 horas de manobras de desmembramentos ao longo de uma viagem, sendo cerca de três horas em cada uma das duas pontes em trechos rasos. 
d) Grande parte dos desmembramentos poderá ser evitada, se for feita a ampliação dos vãos entre pilares centrais das pontes que passam sobre a hidrovia. Neste caso, haverá aumento da eficiência do transporte e uma redução significativa de risco de acidentes.

\subsubsection{Calados de operação}

\section{Calados Máximos}

O calado máximo de operação de um comboio é determinado pela equação de maior produção de transporte, que tende a elevar o calado, confrontada com as restrições físicas da via. O grande gargalo para aumento de calado é o trecho de menor profundidade da via, não importa onde se situe: se há um ponto com profundidade muito restrita, este determina o calado, mesmo que o restante da via apresente grandes profundidades. Este seria um caso típico de necessidade de intervenção, por obras na via, para aumentar a eficiência do sistema de transporte. Estes casos têm ocorrido na hidrovia Tietê-Paraná. Aos poucos, estão sendo eliminadas as restrições existentes, mesmo em apenas algum período do ano, para que os calados máximos previstos possam ser praticados a maior parte do tempo.

A hidrovia Tietê-Paraná tem calado previsto de 2,5 m. Contudo, atualmente os comboios têm, com permissão, navegado com 2,7 m. Cabe aqui, então, avaliar a questão de aumento de calado e verificar o que ocorre com os custos, com a segurança e com a questão ambiental.

A seguir, serão analisados os dados da Tabela 6.4.

- Em princípio, a grande diferença, entre os resultados dos dois calados, é justamente a diminuição de custos por tonelada.km, de $6,7 \%$, obtida com o aumento de apenas $20 \mathrm{~cm}$ de calado. As questões de segurança não foram afetadas porque o trecho mais raso tem profundidade média de 4,1 m.

- Contudo, em épocas de águas rasas, ocorre diminuição do volume de água dos reservatórios, fazendo com que o trecho de profundidade de 4,1 m passe para um valor próximo de 3,0 m. Nestas condições, é impraticável manter a 
operação com calados de $2,7 \mathrm{~m}$. Os riscos de encalhes e de choques no fundo passam a ser mais elevados. O nível de risco de encalhes ou de choques no fundo passa de baixo risco para médio risco, já que a frequiência esperada passa de "ocasional" para "freqüente".

Tabela 6.4 - Comparações de opções de calados, formação de comboios com quatro chatas, mesma potência instalada, $85 \%$ de disponibilidade da via

\begin{tabular}{|l|c|c|}
\hline \multirow{2}{*}{ valores calculados } & \multicolumn{2}{|c|}{ calado } \\
\cline { 2 - 3 } Tempo de ciclo (uma viagem) (dias) & $\mathbf{2 , 5} \mathbf{~ m}$ & $\mathbf{2 , 7}$ m \\
\hline Número de viagens por ano & 8,5 & 8,7 \\
\hline Capacidade de carga por viagem (t) & 35,2 & 34,4 \\
\hline Carga transportada por ano (t) & 4.720 & 5.180 \\
\hline Custo total anual (R\$) & 166.144 & 178.192 \\
\hline Custo por tonelada (R\$ / t) & 3.192 .200 & 3.200 .500 \\
\hline Custo por tonelada por km (R $\$ / t . k m)$ & 19,20 & 17,96 \\
\hline Potência média por motor (kW) & 0,0299 & 0,0281 \\
\hline $\begin{array}{l}\text { Distância percorrida em parada brusca } \\
\text { com calado carregado (m) }\end{array}$ & 473 & 514 \\
\hline
\end{tabular}

\section{Chatas Vazias}

A outra questão ligada a calado de operação é a opção de sempre trafegar de Pederneiras a São Simão com chatas vazias. Como já dito, tanto do ponto de vista econômico como com relação à preservação ambiental, trata-se de uma boa solução. Contudo, a segurança da navegação é prejudicada, aspecto que será analisado a seguir.

A área lateral, exposta ao vento, do comboio, tanto com quatro como com duas chatas vazias, é de $710 \mathrm{~m}^{2}$. Os dois lemes de singradura têm área de $2,7 \mathrm{~m}^{2}$ cada um. 
Utilizando a função ventos para estimar os esforços no comboio vazio e a função manobras, para estimar as forças nos lemes, chega-se que os lemes convencionais instalados no empurrador conseguem compensar ventos de través apenas se estes tiverem intensidade de até $40 \mathrm{~km} / \mathrm{h}(11,1 \mathrm{~m} / \mathrm{s})$. Estes resultados mostram que os níveis de riscos de acidentes de comboios vazios com ventos laterais de alta intensidade, são altíssimos. Inclusive, tais resultados confirmam a experiência com comboios europeus navegando vazios, que não dispensam o auxílio de sistemas como lemes de proa ou de "bow thrusters" (Brolsma et al., 1988).

Se, ao invés dos lemes convencionais, forem instalados lemes de alta sustentação (com "flaps", por exemplo), o desempenho melhora porque há um ganho de cerca de $40 \%$ em coeficiente de sustentação dos lemes. Se o sistema convencional proporciona forças da ordem de $90 \mathrm{kN}$, os lemes de alta sustentação poderão fornecer forças da ordem de $125 \mathrm{kN}$.

A análise dos acidentes ocorridos com comboios em pontes do rio Tietê (Anexo C) mostrou que $69 \%$ dos casos ocorreram com chatas vazias e praticamente todos estes acidentes ocorreram em condições adversas de tempo, com presença de ventos intensos. Apesar de haver pequena quantidade, neste período de 6 anos (1994 a 1999), a freqüência de acidentes foi altíssima, porque o tráfego foi pouco intenso. Há três acidentes em uma mesma ponte, em seis anos, com a estimativa de cerca de 2.000 passagens de comboios em todo este período. Então a frequiência de acidentes em uma ponte (da rodovia SP-333, por exemplo) no período 1994-1999 foi de 1,5 a cada 1000 passagens de comboio sob a ponte, independente se estivesse carregado ou não.

Utilizando o Teorema de Bayes, mostrado no item 4.4.4, pode ser estimada a probabilidade condicional de ocorrer uma colisão de comboio em uma ponte na hidrovia Tietê-Paraná, a partir dos dados de acidentes, mostrados no Anexo C.

Inicialmente, obteve-se a probabilidade de ocorrência de acidentes em pontes com chatas vazias e com chatas carregadas, utilizando como probabilidade incondicional $\mathrm{p}$ $=0,0015$ obtida com os dados de acidentes ocorridos em pontes da hidrovia. Como, em metade das passagens de comboios sob pontes, as chatas estão vazias, são calculadas as probabilidades apresentadas na Tabela 6.5 . 
As estimativas de probabilidades de acidentes são baseadas em dados de acidentes ocorridos em um período de 1994 a 1999. Depois deste período, foram introduzidas alterações no sistema, como aumentos de vãos de algumas pontes e obrigatoriedade de desmembramentos, o que reduziu o número de acidentes. Hoje, portanto, as probabilidades de acidentes em pontes devem ser menores. Mesmo assim, os resultados da Tabela 6.5 indicam a gravidade da questão naquele período e também ressaltam o risco da combinação perigosa de chatas vazias trafegando sob pontes de vãos reduzidos com ventos de alta intensidade.

Tabela 6.5 - Probabilidades estimadas de acidentes em pontes da hidrovia TietêParaná (dados do período de 1994-1999)

\begin{tabular}{|l|c|}
\hline Probabilidade de colisões em pontes & $\begin{array}{c}\text { Colisões por 1000 } \\
\text { passagens }\end{array}$ \\
\hline Com chatas vazias & 2,1 \\
\hline Com chatas carregadas: & 0,9 \\
\hline $\begin{array}{l}\text { Com chatas vazias e com ventos de alta intensidade } \\
\text { (supondo que há ventos fortes em 3\% do tempo) }\end{array}$ & 65,6 \\
\hline
\end{tabular}

As causas básicas destes acidentes têm sido atacadas por aumento de vãos entre pilares, treinamento de tripulação, redução de número de chatas para passagem sob pontes, proteções de pilares, etc.. Mas, ainda permanece uma causa principal: o comboio leve não apresenta capacidade de manobras para fazer frente a ventos de alta intensidade.

A alta probabilidade de acidentes com chatas vazias e com condições de ventos fortes, mostra que medidas preventivas, como informações prévias sobre condições meteorológicas e orientação das tripulações para aguardarem em lugar seguro e não passarem sob pontes com ventos de alta intensidade, deverão diminuir os riscos. Poucas horas de atraso em uma viagem não representam aumentos importantes de custos. Por outro lado, se acontecer um acidente em uma ponte, sempre com potencial de alta gravidade, os custos resultantes poderão ser altíssimos para o armador e para toda a sociedade. Portanto, o que está em jogo na decisão de um 
comandante passar ou não sob uma ponte de vão reduzido em situação de alto nível de risco, não são as poucas horas a mais de viagem e, sim, se vale a pena correr o alto risco de um acidente de alta gravidade.

\subsubsection{Sistemas de manobras}

Se há um sistema que está ligado intimamente à questão da segurança de navegação, este é o de manobras. Para fazer uma avaliação das condições de manobras de comboios, o programa ADAPTA foi processado utilizando três tipos diferentes de sistemas de manobras: sistema convencional, propulsores azimutais e lemes de alta sustentação (Tabela 6.6). As principais alterações, quando há troca de sistemas, referem-se aos custos iniciais e de manutenção e à possibilidade de redução dos riscos no caso de haver melhoria de manobrabilidade.

Tabela 6.6 - Comparações de opções de sistemas de manobras, formação de comboios com quatro chatas, mesma potência instalada, $85 \%$ de disponibilidade da via, calado de 2,7 m

\begin{tabular}{|l|c|c|c|}
\hline \multirow{2}{*}{ valores calculados } & \multicolumn{3}{|c|}{ sistema de manobra } \\
\cline { 2 - 4 } & $\begin{array}{c}\text { Sistema } \\
\text { convencional }\end{array}$ & $\begin{array}{c}\text { Propulsores } \\
\text { azimutais }\end{array}$ & $\begin{array}{c}\text { Lemes de } \\
\text { alto “lift" }\end{array}$ \\
\hline Custos totais (R\$) & 3.192 .200 & 3.452 .600 & 3.268 .600 \\
\hline Custos de manutenção (R\$) & 352.000 & 570.700 & 381.580 \\
\hline Custo por tonelada (R\$ / t) & 19,20 & 21,31 & 19,66 \\
\hline Custo por tonelada por km (R\$/t.km) & 0,0300 & 0,0333 & 0,0307 \\
\hline Preço atualizado do comboio (R\$) & 8.800 .800 & 9.551 .700 & 9.085 .200 \\
\hline $\begin{array}{l}\text { Distância percorrida em parada brusca } \\
- \text { calado carregado (m) }\end{array}$ & 360 & 249 & 360 \\
\hline $\begin{array}{l}\text { Qualidade de manobra (relativa ao } \\
\text { sistema convencional, que vale 100) }\end{array}$ & 100 & 160 & 150 \\
\hline $\begin{array}{l}\text { Nível de risco (fator de redução do } \\
\text { risco em situação de ventos de través } \\
\text { com chatas vazias) }\end{array}$ & 1,0 & 0,5 & 0,6 \\
\hline
\end{tabular}


Com relação aos resultados da Tabela 6.6, podem ser feitas as considerações a seguir.

Há ganhos significativos em qualidade de manobra com propulsores azimutais e um aumento dos custos de transportes $(+11 \%)$. A alternativa de utilização de lemes de melhor desempenho pode ser uma solução mais adequada, já que o acréscimo de custos é menor $(+2,4 \%)$ e o desempenho em manobras melhoraria sensivelmente.

A solução de propulsores azimutais poderia proporcionar uma margem com relação à segurança da navegação que é a distância requerida de parada brusca. O comboio analisado tem, com sistema convencional e a potência fixa em 2 x $330 \mathrm{~kW}$, uma distância de parada em cerca de 2,6 vezes o seu comprimento. O recomendado é que tais distâncias, para se ter níveis de segurança adequados, possuam, no máximo, três vezes o comprimento do comboio, o que está sendo satisfeito. Contudo, a utilização de um propulsor azimutal reduziria esta distância para cerca de 1,8 vezes o comprimento do comboio. O sistema com lemes de alta sustentação manteria a mesma distância de parada do sistema convencional.

Embarcações com boa qualidade de manobra apresentam menores níveis de risco de acidentes porque influem diretamente na frequiência de ocorrência. Em canais sinuosos, ou em situações onde forças externas exigem grande força de reação, a qualidade do sistema instalado deve ser considerada.

Uma alternativa aos sistemas estudados é a instalação de sistemas auxiliares de manobras na proa do comboio. Geralmente também apresentam custos significativos de investimentos, mas contribuem para o aumento de segurança.

\subsubsection{Margens de potência}

Uma alternativa para incrementar a segurança da navegação é a existência de margens de potência, de modo que, em situações de emergência, possa ser utilizada a força total instalada na embarcação para evitar acidentes. 
O critério para verificar se a margem de potência é adequada, foi adotado como: a distância em parada brusca, na condição de calado máximo, deverá ser de no máximo três vezes o comprimento do comboio.

Dado um comboio, com quatro chatas e calado de $2,7 \mathrm{~m}$, serão verificadas as distâncias de paradas bruscas para três situações: margem de potência de $0 \%$, de $10 \%$ e de $20 \%$ sobre a potência utilizada pela embarcação, considerando um fator de serviço de $15 \%$. A Tabela 6.7 mostra os resultados.

Tabela 6.7 - Comparações de margens de potência instalada, formação de comboios com quatro chatas, mesma potência instalada, $85 \%$ de disponibilidade da via, calado de $2,7 \mathrm{~m}$

\begin{tabular}{|l|c|c|c|}
\hline \multirow{2}{*}{ valores calculados } & \multicolumn{3}{|c|}{ margem de potência } \\
\cline { 2 - 4 } & $\mathbf{0 \%}$ & $\mathbf{1 0 \%}$ & $\mathbf{2 0 \%}$ \\
\hline Custos totais $(\mathrm{R} \$)$ & 3.192 .200 & 3.219 .200 & 3.249 .400 \\
\hline Custo por tonelada (R\$ / t) & 19,20 & 19,37 & 19,54 \\
\hline Custo por tonelada por km (R \$t.km) & 0,0300 & 0,0303 & 0,0305 \\
\hline Preço atualizado do comboio (R\$) & 8.800 .800 & 8.943 .000 & 9.085 .200 \\
\hline $\begin{array}{l}\text { Distância percorrida em parada brusca } \\
\text { - calado carregado (m) }\end{array}$ & 360 & 306 & 263 \\
\hline Distância de parada / comprimento & 2,6 & 2,2 & 1,9 \\
\hline
\end{tabular}

Com relação aos resultados mostrados na Tabela 6.7, pode ser observado que a utilização de margens maiores de potência leva a custos não muito maiores, compensando os benefícios com relação à segurança que se obtém com uma potência disponível para situações de emergências.

Obviamente, não basta ter potência instalada a mais, se os propulsores não estiverem projetados adequadamente para aproveitá-la.

A potência instalada maior, considerando um mesmo deslocamento de comboio, está diretamente ligada à segurança da navegação. 


\subsubsection{Velocidades de operação}

As velocidades de comboios carregados geralmente variam em uma faixa muito estreita, situada entre $10 \mathrm{~km} / \mathrm{h}(2,8 \mathrm{~m} / \mathrm{s})$ e $14 \mathrm{~km} / \mathrm{h}(3,9 \mathrm{~m} / \mathrm{s})$. Os grandes comboios americanos tendem a operar próximo de $10 \mathrm{~km} / \mathrm{h}$, enquanto europeus têm operado em velocidades próximas de $13 \mathrm{~km} / \mathrm{h}$. Quais as vantagens e as desvantagens? Para procurar responder a esta questão, foram processados casos com variações de velocidades de operação, para o comboio de quatro chatas com $2,7 \mathrm{~m}$ de calado.

A Tabela 6.8 mostra os resultados obtidos. A Figura 6.1 mostras as variações de custo pela velocidade média. A Tabela 6.9 mostra duas condições de tráfego exatamente iguais, mas com taxas de embarque e de desembarque diferentes.

Tabela 6.8 - Comparações entre velocidades de operação, formação de comboios com quatro chatas, mesma potência instalada, profundidade $7,5 \mathrm{~m}$, $85 \%$ de disponibilidade da via, calado de $2,7 \mathrm{~m}$

\begin{tabular}{|l|c|c|c|c|}
\hline \multirow{2}{*}{ valores calculados } & \multicolumn{4}{|c|}{ potência instalada (kW) } \\
\cline { 2 - 5 } & $\mathbf{2}$ x 250 & $\mathbf{2} \times \mathbf{3 5 0}$ & $\mathbf{2}$ x 450 & $\mathbf{2}$ x 550 \\
\hline Velocidade média de viagem (m/s) & 3,25 & 3,57 & 3,94 & 4,30 \\
\hline Velocidade comboio carregado (m/s) & 2,78 & 3,24 & 3,59 & 3,85 \\
\hline Total de carga transportada por ano (t) & 169.800 & 178.432 & 187.406 & 194.927 \\
\hline $\begin{array}{l}\text { Acréscimo de quantidade anual de carga } \\
\text { em relação à condição de 2 x 250 kW }\end{array}$ & 0 & $5,1 \%$ & $10,4 \%$ & $14,8 \%$ \\
\hline Custos totais anuais (milhões de R\$) & 2,93 & 3,23 & 3,58 & 3,94 \\
\hline Custo por tonelada (R\$ / t) & 17,24 & 18,09 & 19,10 & 20,22 \\
\hline Custo por tonelada por km (R\$/t.km) & 0,0270 & 0,0283 & 0,0298 & 0,0316 \\
\hline $\begin{array}{l}\text { Acréscimo de custo em relação à } \\
\text { condição de 2 x 250 kW }\end{array}$ & 0 & $4,8 \%$ & $10,4 \%$ & $17,0 \%$ \\
\hline Fator de mérito de transporte (t.km/h/kW) & 82,8 & 69,3 & 59,0 & 51,2 \\
\hline
\end{tabular}




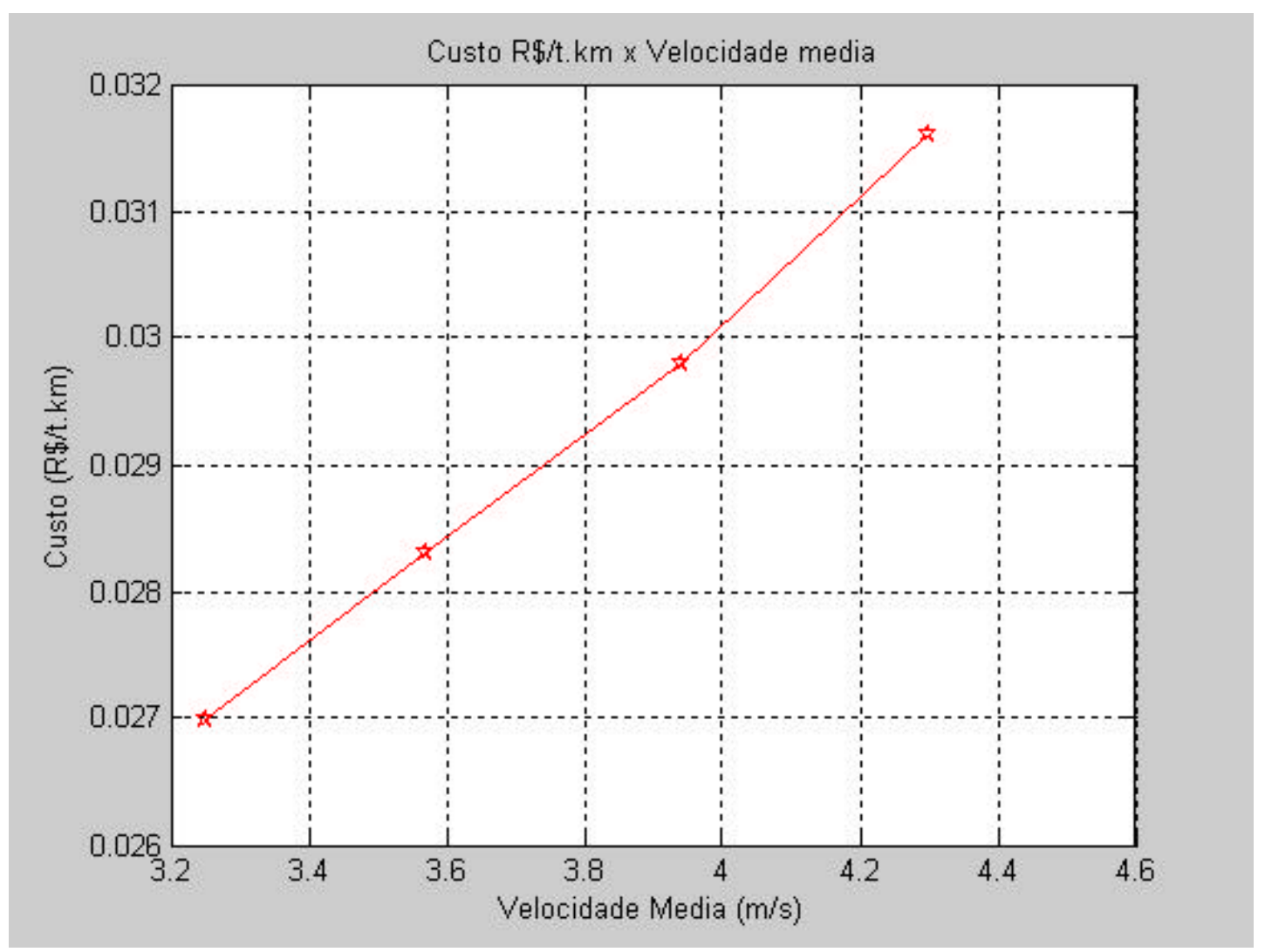

Figura 6.1 - Variação do custo em função da velocidade média de viagem

Tabela 6.9 - Comparações entre comboios de mesmas velocidades, com taxas de embarques diferentes e potência instalada de 2 x $350 \mathrm{~kW}$

\begin{tabular}{|l|c|c|}
\hline \multirow{2}{*}{ valores calculados } & \multicolumn{2}{|c|}{$\begin{array}{l}\text { taxas de carga e } \\
\text { descarga }\end{array}$} \\
\cline { 2 - 3 } & $240 \mathrm{t} / \mathrm{h}$ & $480 \mathrm{t} / \mathrm{h}$ \\
\hline Velocidade média de viagem (m/s) & 3,57 & 3,57 \\
\hline Velocidade comboio carregado (m/s) & 3,24 & 3,24 \\
\hline Total de carga transportada por ano (t) & 178.432 & 199.180 \\
\hline Custos totais anuais (milhões de R\$) & 3,23 & 3,58 \\
\hline Custo por tonelada (R\$ / t) & 18,09 & 17,96 \\
\hline Custo por tonelada por km (R\$/t.km) & 0,0283 & 0,0281 \\
\hline Fator de mérito de transporte (t.km/h/kW) & 69,3 & 69,3 \\
\hline
\end{tabular}


Os resultados mostram que há um acréscimo de custo de $17 \%$ com o aumento da velocidade média de viagem de 3,25 a $4,30 \mathrm{~m} / \mathrm{s}$, correspondendo, também, a um acréscimo do total de carga transportada por ano. Estes resultados refletem a importância dos tempos gastos em carga e de carga e dos tempos de desmembramentos em eclusas, pontes e canais.

Um aumento significativo de velocidade de viagem, não é acompanhado proporcionalmente pela quantidade de carga transportada anualmente, porque os tempos fixos, em terminais e em desmembramentos, são muito altos.

A influência dos tempos de carregamento e descarregamento nos resultados é mostrada na Tabela 6.9. Dobrando as taxas e carga e descarga, é aumentado o total anual de carga transportada em mais de $11 \%$.

Com relação à segurança na navegação, o aumento de velocidades nas vias não implica em aumento, mas em decréscimo do risco, pelos seguintes fatos:

- as passagens identificadas como críticas (pontes, canais restritos, curvas) terão as mesmas restrições de velocidades em todas as condições analisadas, ou seja, um aumento de velocidade média não significa em aumento de velocidade em trechos críticos;

- como bom efeito colateral do aumento de velocidade, o acréscimo de potência instalada proporciona maior segurança em manobras e diminui os tempos e distâncias em paradas de emergência;

- o risco poderia aumentar com velocidades maiores se o tráfego de embarcações fosse intenso, o que não acontece no caso em questão.

Com relação à questão de interferências ambientais, também as restrições de velocidades continuam as mesmas em trechos mais vulneráveis (águas rasas e /ou com restrições de largura). As emissões de gases (poluição do ar) por ano, que são proporcionais aos gastos de combustível, serão mais elevadas nas condições com maiores velocidades, como mostra Tabela 6.10. Embora de importância relativamente 
pequena no contexto da interferência ambiental de um sistema de transporte de cargas, a quantidade de emissões de poluentes de um comboio passará a exigir maior atenção quando ocorrer concentração de tráfego de embarcações.

As escolhas das alternativas de velocidades, portanto, são dependentes dos requisitos que o armador possa ter com relação ao volume de carga transportada por ano. $14,8 \%$ de carga transportada a mais por ano significa, nas condições analisadas, $17 \%$ de acréscimo de custo por tonelada.km e aumento de $147 \%$ de volume de combustível e de emissões de gases anuais.

Tabela 6.10 - Variação de emissões de gases pelos motores, por ano, nas quatro alternativas

\begin{tabular}{|l|c|c|c|c|}
\hline \multirow{2}{*}{ valores calculados } & \multicolumn{4}{|c|}{ potência instalada (kW) } \\
\cline { 2 - 5 } & $\mathbf{2}$ x 250 & $\mathbf{2}$ x 350 & $\mathbf{2}$ x 450 & $\mathbf{2}$ x 550 \\
\hline Potência total média utilizada (kW) & 406 & 534 & 694 & 872 \\
\hline Número de viagens por ano & 32,7 & 34,4 & 36,1 & 37,6 \\
\hline $\begin{array}{l}\text { Variação da quantidade de emissões anuais } \\
\text { em relação à condição de } \mathbf{2} \text { x 250 kW }\end{array}$ & 0 & $38 \%$ & $88 \%$ & $147 \%$ \\
\hline
\end{tabular}

Por outro lado, se há espaço para redução de custos de outras maneiras que não aumentos de velocidades, estes devem ser explorados. Aumento de taxas de carga e descarga, por exemplo, contribuem para diminuições significativas de custos.

\subsection{Hidrovia do Araguaia}

Este item tem o objetivo de apresentar apenas alguns aspectos da aplicação do modelo em um rio em corrente livre e com baixas profundidades. As avaliações de todas as alternativas de projeto e operação no rio Araguaia deverão ser fruto de estudos futuros, inclusive quando houver maior clareza quanto a localizações e quantidades de cargas disponíveis e definição sobre realização de obras para redução de restrições localizadas da via. 


\subsubsection{Descrição do Transporte}

A Araguaia-Tocantins é uma hidrovia em projeto, sem ainda apresentar movimentação significativa de cargas. O rio Araguaia depende da realização de algumas obras de porte reduzido (derrocamentos e dragagens) para viabilizar sua utilização por comboios fluviais de carga durante o ano todo.

O Araguaia é um rio em corrente livre, cujo leito apresenta baixa declividade. Em época de cheia, as águas invadem suas margens, resultando em grandes larguras. Existem, ao longo de grande extensão do rio, bancos de areia que, ano a ano, mudam de lugar, alterando a localização do canal de navegação (percurso de maior profundidade). Há um transporte acentuado de sedimentos (areia fina), evidenciado pela coloração "barrenta" das águas do rio Araguaia. A análise do perfil do fundo do rio (IPT, 1981b) indica que ocorrem alternâncias de locais rasos e profundos. São raras grandes extensões contínuas, apenas com trechos rasos ou apenas com trechos profundos.

$\mathrm{O}$ rio Araguaia apresenta fundo arenoso desde as proximidades de sua nascente (Baliza, a $1.758 \mathrm{~km}$ da faz) até próximo da cidade de Conceição do Araguaia (a 504 $\mathrm{km}$ de sua foz). Deste ponto até a foz do rio, ocorrem travessões rochosos rasos.

O modelo foi aplicado para o caso de transporte de grãos da região de Aruanã (GO) até a cidade de Xambioá (TO), em um percurso de $1.247 \mathrm{~km}$ pelo rio Araguaia. Xambioá é escolhida como porto final do transporte hidroviário porque o trecho imediatamente à jusante possui corredeiras que impossibilitam a navegação em águas médias e baixas. De Xambioá, a carga é transportada por caminhões até Estreito (TO), onde é embarcada em trens e segue, por trechos da Ferrovia Norte-Sul e da Estrada de Ferro Carajás, com destino ao porto de Ponta da Madeira (São Luís, MA). Não foram consideradas cargas de retorno.

Uma avaliação das condições de navegabilidade do rio Araguaia (IPT, 1981b), nַo $\underline{\text { trecho escolhido, }}$, sem considerar qualquer obra no leito do rio, levou à adoção das seguintes restrições de calados:

$>$ durante três meses do ano, o calado máximo é de 2,5m; 
em outros três meses, o calado máximo passa a ser de $1,5 \mathrm{~m}$;

em outros três meses, o calado máximo é de 1,0m;

nos três meses restantes, não há calado para uma navegação comercial viável.

Com o objetivo de apresentar aspectos da aplicação do modelo em um rio de corrente livre e com baixas profundidades

Pelas características físicas do rio, a principal preocupação, com relação à questão ambiental, é que a navegação não acelere o processo natural existente de perda de estabilidade das margens arenosas. Assim, em época de águas baixas e médias (nos seis meses onde as restrições de calado encontram-se entre $1,0 \mathrm{~m}$ e $1,5 \mathrm{~m}$ ), a navegação nos trechos estreitos do rio não pode gerar ondas que prejudiquem a estabilidade das margens. Em época de águas altas (cerca de três meses), as margens regulares encontram-se, quase sempre, submersas e as larguras do rio são muito grandes.

Com relação à segurança da navegação, os riscos estão associados principalmente à possibilidade de ocorrência de encalhes nos vários trechos rasos presentes em todo o trajeto, particularmente em épocas de águas baixas.

\subsubsection{Estimativa de Custos de Transporte}

A utilização de um comboio em um rio que apresenta trechos com grandes restrições de profundidades requer cuidados especiais. O empurrador não deve possuir calado carregado maior que o menor calado de chatas com que se pretende navegar. Assim, fixou-se o calado máximo do empurrador em 1,0 m.

Para obter-se uma compatibilidade entre o calado reduzido e a potência total que deve ser instalada, houve necessidade de adoção de três conjuntos motor-redutor-hélice. Dividindo-se a potência total necessária por três, foi possível a adoção de hélices com diâmetros de $0,80 \mathrm{~m}$, adequados à instalação na popa do empurrador com 1,0 m de calado. As características básicas do empurrador são mostradas na Tabela 6.11. 
No percurso escolhido, por conta dos raios de curvatura existentes em várias curvas do rio, existentes do rio, o comboio considerado deve possuir um comprimento máximo da ordem de $100 \mathrm{~m}$. A Tabela 6.12 apresenta as dimensões adotadas das chatas do comboio.

Duas opções de valores de pontais das chatas (e, consequentemente, de calados máximos) foram escolhidas para que fossem avaliadas sua influência sobre os custos de transporte. Os resultados das comparações entre chatas com pontal de 2,3 m e chatas com pontal de $1,8 \mathrm{~m}$, para um comboio de quatro chatas na formação duas a duas, são mostrados na Tabela 6.13.

Tabela 6.11 - Características do empurrador utilizado nos cálculos da Tabela 6.13

\begin{tabular}{|l|c|}
\hline Comprimento total $(\mathrm{m})$ & 18,00 \\
\hline Boca moldada $(\mathrm{m})$ & 8,00 \\
\hline Calado carregado $(\mathrm{m})$ & 1,00 \\
\hline Coeficiente de bloco & 0,65 \\
\hline Pontal moldado (m) & 1,40 \\
\hline Número de motores e de hélices & 3 \\
\hline Potência de cada motor (kW) & 170 \\
\hline Diâmetro dos hélices (m) & 0,80 \\
\hline
\end{tabular}

Tabela 6.12 - Características das chatas utilizadas nos cálculos da Tabela 6.13

\begin{tabular}{|l|c|}
\hline Comprimento total (m) & 40,00 \\
\hline Boca moldada (m) & 10,00 \\
\hline Calado carregado (m) & 2,00 ou 1,50 \\
\hline Coeficiente de bloco & 0,85 \\
\hline Pontal moldado (m) & 2,30 ou 1,80 \\
\hline
\end{tabular}

Os resultados da Tabela 6.13 apontam para uma equivalência em custos de carga transportada obtidos nas duas opções de pontais. As chatas com pontal de 1,8 m têm menor custo de construção e um menor peso leve, resultando em carga útil com calado de 1,5 m maior que a carga útil em um mesmo calado que as chatas com 
pontal de 2,3 m. Por outro lado, as chatas de maior pontal têm uma maior flexibilidade de utilização, já que podem operar com calado de até 2,0 m.

Tabela 6.13 - Comparações de opções de pontal de chatas na hidrovia Araguaia. Comboio de quatro chatas, formação duas a duas, com empurrador da Tabela 6.11 e chatas da Tabela 6.12

\begin{tabular}{|c|c|c|c|}
\hline \multirow{2}{*}{\multicolumn{2}{|c|}{ valores calculados }} & \multicolumn{2}{|c|}{ pontal das chatas } \\
\hline & & $2,3 \mathrm{~m}$ & $1,8 \mathrm{~m}$ \\
\hline \multicolumn{2}{|c|}{ Custo de construção das chatas $(\mathrm{R} \$$ ) } & $\mathrm{R} \$ 2.826 .000,00$ & $\mathrm{R} \$ 2.212 .000,00$ \\
\hline \multirow[t]{3}{*}{ águas altas } & Calado das chatas & $2,0 \mathrm{~m}$ & $1,5 \mathrm{~m}$ \\
\hline & Carga útil do comboio & $2.280 \mathrm{t}$ & $1.695 \mathrm{t}$ \\
\hline & Velocidade média & $10,3 \mathrm{~km} / \mathrm{h}$ & $10,9 \mathrm{~km} / \mathrm{h}$ \\
\hline \multirow[t]{3}{*}{ águas médias } & Calado das chatas & $1,5 \mathrm{~m}$ & $1,5 \mathrm{~m}$ \\
\hline & Carga útil do comboio & $1.600 \mathrm{t}$ & $1.695 \mathrm{t}$ \\
\hline & Velocidade média & $10,3 \mathrm{~km} / \mathrm{h}$ & $10,3 \mathrm{~km} / \mathrm{h}$ \\
\hline \multirow[t]{3}{*}{ águas baixas } & Calado das chatas & $1,0 \mathrm{~m}$ & $1,0 \mathrm{~m}$ \\
\hline & Carga útil do comboio & $920 \mathrm{t}$ & $1.015 \mathrm{t}$ \\
\hline & Velocidade média & $10,8 \mathrm{~km} / \mathrm{h}$ & $10,8 \mathrm{~km} / \mathrm{h}$ \\
\hline \multicolumn{2}{|c|}{ Número total de viagens (anual) } & 25 & 26 \\
\hline \multicolumn{2}{|c|}{ Carga total transportada (anual) } & $40.200 \mathrm{t}$ & $37.350 \mathrm{t}$ \\
\hline \multicolumn{2}{|c|}{ Custo da tonelada transportada (anual) } & $49,75 \mathrm{R} \$ / \mathrm{t}$ & $49,40 \mathrm{R} \$ / \mathrm{t}$ \\
\hline \multicolumn{2}{|c|}{ Custo de tonelada por km (anual) } & 0,0400 R $\$ /(\mathrm{t} . \mathrm{km})$ & $0,0396 \mathrm{R} \$ /(\mathrm{t} . \mathrm{km})$ \\
\hline
\end{tabular}

A comparação dos valores de frete atualmente praticados em outras hidrovias com os custos calculados de transporte de soja no rio Araguaia (Tabela 6.13), ainda sem obras que permitam a navegação comercial o ano todo e ainda sem cargas de retorno, indica a viabilidade comercial deste transporte. Um exemplo de fretes: no sistema de pesquisas de cotação de fretes ("sifreca") da Escola Superior de Agricultura Luiz de 
Queiroz da Universidade de São Paulo (http://sifreca.esalq.usp.br), o frete de transporte hidroviário de soja a granel de Porto Velho (RO) a Itacoatiara (AM), em um percurso de $1.115 \mathrm{~km}$, estava cotado em $\mathrm{R} \$ 42,98$ por tonelada $(0,0385$ reais/t.km) no período de 19/04/2003 a 23/05/2003.

Uma comparação entre comboios formados com duas chatas em linha e com quatro chatas ( 2 x 2), com pontais de 1,8 m, é apresentada na Tabela 6.14 .

Tabela 6.14 - Comparações de desempenho de um comboio de duas chatas em linha com um comboio de quatro chatas $(2 \times 2)$. Pontal das chatas de $1,8 \mathrm{~m}$

\begin{tabular}{|c|c|c|c|}
\hline \multicolumn{2}{|c|}{ valores calculados } & 2 chatas em linha & 4 chatas $(2 \times 2)$ \\
\hline \multicolumn{2}{|c|}{ Custo de construção das chatas } & $\mathrm{R} \$ 1.106 .000,00$ & $\mathrm{R} \$ 2.212 .000,00$ \\
\hline \multicolumn{2}{|c|}{ Potência instalado no empurrador } & $2 \times 170 \mathrm{~kW}$ & $3 \times 170 \mathrm{~kW}$ \\
\hline \multicolumn{2}{|c|}{ Custo de construção do empurrador } & $\mathrm{R} \$ 930.000,00$ & $\mathrm{R} \$ 1.300 .000,00$ \\
\hline \multirow[t]{3}{*}{ águas altas } & Calado das chatas & $1,5 \mathrm{~m}$ & $1,5 \mathrm{~m}$ \\
\hline & Carga útil do comboio & $847 \mathrm{t}$ & $1.695 \mathrm{t}$ \\
\hline & Velocidade média & $11,1 \mathrm{~km} / \mathrm{h}$ & $10,9 \mathrm{~km} / \mathrm{h}$ \\
\hline \multirow[t]{3}{*}{ águas médias } & Calado das chatas & $1,5 \mathrm{~m}$ & $1,5 \mathrm{~m}$ \\
\hline & Carga útil do comboio & $847 \mathrm{t}$ & $1.695 \mathrm{t}$ \\
\hline & Velocidade média & $10,5 \mathrm{~km} / \mathrm{h}$ & $10,3 \mathrm{~km} / \mathrm{h}$ \\
\hline \multirow[t]{3}{*}{ águas baixas } & Calado das chatas & $1,0 \mathrm{~m}$ & $1,0 \mathrm{~m}$ \\
\hline & Carga útil do comboio & $507 \mathrm{t}$ & $1.015 \mathrm{t}$ \\
\hline & Velocidade média & $11,1 \mathrm{~km} / \mathrm{h}$ & $10,8 \mathrm{~km} / \mathrm{h}$ \\
\hline \multicolumn{2}{|c|}{ Número total de viagens (anual) } & 26 & 26 \\
\hline \multicolumn{2}{|c|}{ Carga total transportada (anual) } & $18.960 \mathrm{t}$ & $37.350 \mathrm{t}$ \\
\hline \multicolumn{2}{|c|}{ Custo da tonelada transportada (anual) } & $62,73 \mathrm{R} \$ / \mathrm{t}$ & $49,40 \mathrm{R} \$ / \mathrm{t}$ \\
\hline \multicolumn{2}{|c|}{ Custo de tonelada por km (anual) } & $0,0503 \mathrm{R} \$ /(\mathrm{t} . \mathrm{km})$ & $0,0396 \mathrm{R} \$ /(\mathrm{t} . \mathrm{km})$ \\
\hline
\end{tabular}


Os resultados da Tabela 6.14 mostram a conveniência de utilização de um comboio com quatro chatas, pelo fato deste proporcionar menores custos de transporte.

\subsubsection{Avaliação da Interferência Ambiental}

Adotou-se a estimativa de altura de ondas geradas pelo comboio (item 4.5.1, Capítulo 4), em função da velocidade e da distância do comboio às margens, como critério para evitar que ocorressem problemas de estabilidade das margens.

A Figura 6.2 mostra os valores de altura de ondas junto às margens, em função da distância comboio-margem e da velocidade de passagem.

ondas geradas por comboio

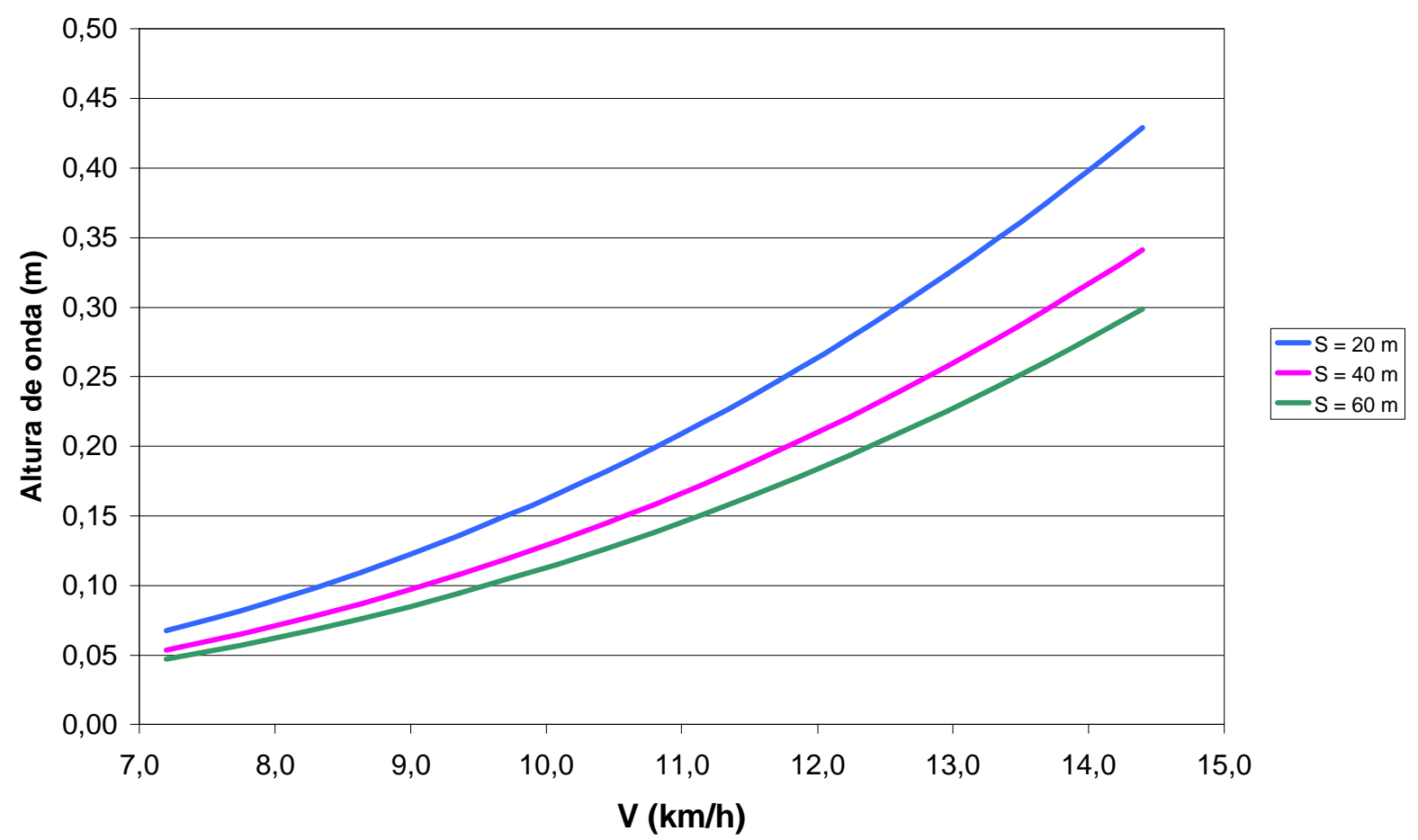

Figura 6.2 - Altura prevista de ondas em função da velocidade do comboio V e da distância à margem $\mathrm{S}$

O limite máximo de altura de ondas, escolhido como critério para verificação da velocidade máxima de passagem do comboio em trechos com restrições de largura, foi de $0,15 \mathrm{~m}$. Este limite foi adotado baseado em recomendações existentes em bibliografias que indicam que, na ausência de resultados experimentais dos efeitos 
efetivos das ondas sobre as margens de um determinado trecho de rio, pode-se admitir que a altura limite de ondas provocadas por embarcações deva ser igual à maior altura de ondas provocadas por ventos no local (Maynord, 2000a). Esta recomendação parte do princípio que não haverá interferência importante nas margens se, no máximo, houver equivalência com o que ocorre naturalmente em determinadas condições ambientais.

Assumindo que, em determinados trechos de navegação, haveria proximidade do comboio com as margens, a ponto de provocar ondas com alturas maiores que $0,15 \mathrm{~m}$, o programa recalculou as velocidades de passagem do comboio por tais trechos. Foram, então, recalculados os novos custos, já que ocorreram aumentos de tempos de viagem.

Com $10 \%$ do percurso do comboio sendo realizado com distância às margens menores ou iguais a 40m, a redução necessária de velocidades levou a um acréscimo de custos da ordem de $5 \%$.

A Tabela 6.15 apresenta as velocidades do comboio em cada um dois 14 trechos em que foi subdividido o percurso entre Aruanã e Xambioá, com destaque aos trechos considerados com grande proximidade do comboio às margens.

A Tabela 6.16 apresenta as diferenças de custos calculados com e sem a restrição de formação de ondas devidas à passagens do comboio.

Cabe a observação que os dados assumidos de distâncias de comboios a margens e de suscetibilidade das margens a ondas geradas pelos comboios (expressa pela adoção de um valor limite de altura de onda) não são exatos, não exprimindo, possivelmente, a relação real entre as ondas e a estabilidade das margens do rio Araguaia. O ideal é que sejam realizados levantamentos e experimentos para verificação dos possíveis efeitos de ondas sobre as margens de cada trecho específico do rio. 
Tabela 6.15 - Características médias dos trechos entre Aruanã e Xambioá. Velocidades indicadas em viagem de descida do rio (velocidade de corrente $=0,7 \mathrm{~m} / \mathrm{s})$, com calado de 1,5 $\mathrm{m}$ e águas médias, 4 chatas

\begin{tabular}{|c|c|c|c|c|c|}
\hline Trecho & $\begin{array}{l}\text { Extensão } \\
(\mathrm{km})\end{array}$ & $\begin{array}{l}\text { Largura } \\
\text { média }(\mathrm{m})\end{array}$ & $\begin{array}{l}\text { Profundidade } \\
\text { média (m) }\end{array}$ & $\begin{array}{c}\text { Velocidade } \\
\text { média do } \\
\text { comboio }(\mathrm{km} / \mathrm{h})\end{array}$ & $\begin{array}{c}\text { Velocidade } \\
\text { restrita } \\
(\mathrm{km} / \mathrm{h}) \\
\end{array}$ \\
\hline 1 & 163 & 300 & 2,3 & 12,7 & - \\
\hline 2 & 59 & 300 & 2,8 & 12,2 & - \\
\hline 3 & 243 & 300 & 2,7 & 12,2 & - \\
\hline 4 & 76 & 300 & 2,5 & 12,1 & 11,2 \\
\hline 5 & 106 & 300 & 2,6 & 12,1 & 11,2 \\
\hline 6 & 82 & 300 & 2,6 & 12,0 & 11,2 \\
\hline 7 & 85 & 300 & 2,6 & 12,0 & - \\
\hline 8 & 18 & 400 & 2,5 & 11,8 & - \\
\hline 9 & 58 & 400 & 2,5 & 11,8 & - \\
\hline 10 & 78 & 400 & 2,6 & 11,8 & - \\
\hline 11 & 99 & 400 & 2,8 & 11,9 & - \\
\hline 12 & 35 & 400 & 3,0 & 12,0 & - \\
\hline 13 & 55 & 400 & 2,9 & 12,0 & - \\
\hline 14 & 90 & 400 & 3,2 & 12,2 & - \\
\hline
\end{tabular}

Tabela 6.16 - Comparações entre custos, com e sem restrições de velocidades em trechos sensíveis a ação de ondas provocadas pelo comboio

\begin{tabular}{|l|c|c|}
\hline valores calculados & sem restrições & com restrições \\
\hline Número anual de viagens & 26 & 25 \\
\hline Total de carga transportada por ano & $37.350 \mathrm{t}$ & $35.900 \mathrm{t}$ \\
\hline Custo por tonelada & $\mathrm{R} \$ 49,40$ & $\mathrm{R} \$ 51,41$ \\
\hline Custo por tonelada por $\mathrm{km}$ & $\mathrm{R} \$ 0,0396 /(\mathrm{t} . \mathrm{km})$ & $\mathrm{R} \$ 0,0412 /(\mathrm{t} . \mathrm{km})$ \\
\hline
\end{tabular}




\section{CONCLUSÕES E RECOMENDAÇÕES}

\subsection{Síntese do Trabalho}

O trabalho apresentado teve duas motivações iniciais básicas. A primeira, foi a constatação de que, na conjuntura atual, em que a questão ambiental está sempre presente, as hidrovias cada vez menos terão obras de grande porte para eliminação das restrições à navegação que possam existir. Assim, há necessidade de orientar os procedimentos de projetos de embarcações para que se obtenha o maior aproveitamento possível da atividade comercial de transportes, convivendo, de uma forma mais otimizada, com todas as restrições das vias.

A segunda motivação, foi dada pela percepção da necessidade de ampliação dos horizontes de projeto, de modo que, ao se buscar bons desempenhos econômicos da exploração da navegação, também sejam buscadas, de uma forma racional e coordenada, melhores condições de segurança e baixos níveis de interferência ambiental.

Neste contexto, foi desenvolvido um modelo de projeto que, durante o processo de busca de alternativas para que se obtenha menores custos de transporte, faz verificações dos níveis de risco de acidentes e de interferências ambientais. O projeto de embarcações para uma melhor exploração das restrições existentes nas vias passa, 
assim, obrigatoriamente, pela análise de riscos à navegação e pela verificação de possíveis problemas de ordem ambiental.

A utilização de dados experimentais, obtidos em ensaios com modelos em escala reduzida e ensaios em escala real, na definição de valores importantes para a simulação da operação de comboios fluviais, contribuiu para o aumento da confiabilidade do modelo. Assim, valores de resistência à propulsão, coeficientes propulsivos, desempenho em manobras respostas, tempos de parada brusca, adotados no programa, foram validados por resultados de ensaios realizados com comboios de diferentes composições de chatas.

A aplicação do modelo foi moldada às especificidades das hidrovias brasileiras, o que levou à adoção de algumas hipóteses simplificadoras, como, por exemplo, a ausência de congestionamentos. As escolhas de tipos de acidentes e de fatores de riscos, que integraram o modelo, também foram feitas levando em consideração as características físicas e operacionais das hidrovias do Brasil.

\subsection{Conclusões}

O modelo apresentado tem o efeito de aglutinar os aspectos importantes da relação hidrovia-comboio, propondo formas de análise e de quantificação dos desempenhos relacionados à eficiência, à segurança e ao meio ambiente. As formas e os métodos de análises podem ser aprimorados ao longo do tempo, sendo que a introdução de alterações será facilitada pelas características da linguagem MATLAB, utilizada no programa.

O grande ganho com o modelo proposto é a ampliação da visão da utilização de embarcações em hidrovias. Deve proporcionar, aos armadores, aos projetistas, aos administradores das hidrovias e aos operadores das embarcações, um instrumento para o melhor entendimento das complexas relações entre via e comboios fluviais.

O modelo desenvolvido pode constituir-se em um primeiro estágio da elaboração de um método geral de projeto e de planejamento da operação, que leve em 
consideração todos os elementos do transporte hidroviário, incluindo as alternativas de realização de obras para redução de restrições da via e os custos externos (ou sociais) envolvidos em todo o sistema.

As limitações impostas pela falta de dados históricos de acidentes específicos, em cada hidrovia de interesse, não invalidam o modelo de risco adotado, mas introduzem algumas incertezas que, certamente, exigem um acompanhamento da evolução dos fatos relativos à navegação fluvial no Brasil e a realização de atualizações futuras das bases de dados.

O modelo desenvolvido não apresenta, necessariamente, as melhores soluções para todos os temas levantados. Um aprimoramento que deve ser feito no modelo é a introdução de modelagem matemática das manobras de comboios para que as respostas das embarcações nas situações mais críticas sejam cada vez melhor entendidas.

Com relação às soluções de alternativas de projeto, podem ser destacadas, a seguir, algumas conclusões.

- A aplicação do modelo para a hidrovia Tietê-Paraná, por esta apresentar uma sequiência de barragens, constituindo grandes reservatórios, não mostrou interferências ambientais importantes. Nesta hidrovia, a questão da segurança da navegação (passagens sob pontes, trânsito com chatas vazias, entradas em eclusas), com a exigência de um número significativo de desmembramentos de comboios, mostrou-se determinante, com reflexos sobre o desempenho econômico do transporte hidroviário.

- A aplicação do modelo para a hidrovia do Araguaia, rio em corrente livre, mostrou a necessidade de redução de velocidades dos comboios em trechos mais estreitos da via, a fim de não interferir na estabilidade das margens arenosas. A redução de velocidades de operação nos trechos mais estreitos deve levar a um decréscimo da eficiência do transporte, com um aumento de custo do transporte de cargas da ordem de $5 \%$. 
- O nível de exigência do sistema de manobras de um comboio é muito alto, justificando investimentos para que ocorra um aumento efetivo da qualidade de manobras. A troca de lemes convencionais por lemes de alta sustentação pode ser uma solução viável técnica e economicamente.

- Os custos resultantes de restrições à navegação, que obrigam a reduções de velocidades em alguns trechos e a desmembramentos de comboios em algumas passagens, são importantes e devem ser verificados com rigor. Pode ocorrer, por exemplo, que comboios de menor porte tenham vantagens sobre comboios com formações maiores, devido aos pesos dos tempos e custos adicionais de desmembramentos.

- A associação de adoção de determinados procedimentos operacionais ao aumento do nível de risco é uma contribuição pretendida pelo presente trabalho. Ao mesmo tempo que se pensa em aumentar a eficiência econômica do transporte, de resultados imediatos e palpáveis, deve haver a preocupação de avaliar as implicações das decisões sobre a segurança da navegação e sobre o meio ambiente.

\subsection{Recomendações}

O modelo deve ser aplicado a outras hidrovias, com características diferentes da hidrovia Tietê-Paraná. Novas aplicações poderão gerar necessidades de adaptações de algumas partes do modelo desenvolvido no presente trabalho.

Ao longo do tempo, quando houver mais dados disponíveis de acidentes de comboios em hidrovias e um maior grau de detalhamento das características da via, o programa deverá sofrer alterações. Também poderá ser aumentada a precisão do modelo, por meio de um maior detalhamento das características das vias percorridas.

As interferências ambientais da passagem de comboios são diretamente ligadas às características físicas de cada trecho. A realização, no futuro, de um detalhamento minucioso das regiões mais críticas de cada hidrovia, com armazenamentos de dados 
da evolução dos possíveis problemas ocorridos em margens e daqueles relacionados com o fundo do rio, será uma tarefa que contribuirá para a conservação das vias, assim como proporcionará meios para atualização dos estudos dos efeitos das passagens de comboios.

O ideal é que cada hidrovia tenha um sistema diferenciado de acompanhamento das questões relacionadas à segurança e ao meio ambiente. Desenvolvendo modelos especiais para cada hidrovia, detalhando, quilômetro a quilômetro, todas as variáveis que influenciam o risco de acidentes, no desempenho operacional e na interferência ambiental, as administradoras das hidrovias estarão prestando um grande serviço à sociedade.

Do lado dos armadores e operadores das embarcações, a adoção de uma visão mais abrangente do sistema hidroviário de cargas, com preocupações com o aumento do desempenho econômico do transporte, mas permanentemente aliadas às questões de segurança e ambientais, levará ao aprimoramento de suas embarcações e de seus procedimentos operacionais. Trarão, assim, benefícios para si e, porque estarão atuando no sentido de diminuir os custos sociais do transporte, para todo o país.

Uma sequiência deste trabalho pode ser o desenvolvimento de um método geral de projeto e de planejamento da operação de comboios fluviais, incluindo a análise de alternativas de realização de obras para redução de restrições da via, assim como levando em consideração os custos externos envolvidos no sistema de transporte. 


\title{
REFERÊNCIAS BIBLIOGRÁFICAS
}

\begin{abstract}
AMERICAN ASSOCIATION OF STATE HIGHWAY AND TRANSPORTATION OFFICIALS - AASHTO (1991) Guide specification and commentary for vessel collision design of highway bridges: Volume I - Final Report. Highway Subcommittee on Bridges and Structures. AASHTO, Washington DC, February 1991, 133 p.
\end{abstract}

ANKUDINOV, V.K. et al. (1990) Manoeuvring performance of tug assemblies in restricted waterways. Proceedings Joint International Conference on Marine Simulation and Ship Manoeuvrability - MARSIM; ICSM 90, Tokyo, pp. 517-525.

AUCHER, M. (1972) A review of some unconventional manoeuvring devices. 13th International Towing Tank Conference (ITTC), Berlin-Hamburg: Report of Manoeuvrability Committee, Appendix VIII, 1972.

BARRASS, C. B. (1979) The phenomena of ship squat. International Shipbuilding Progress, 26: pp. 44-47, 1979.

BASIN, A. M. ; MINIOVICH, I. Y. (1963) Empirical formulas for estimating the wake fraction and thrust deduction factors for ocean and inland waterway vessels. In: Basin, A.M. et al., Theory of design of screw propellers, Sudostroeniye, Leningrad. 1963, pp. 143-148. English translation: Latorre et al. (1982).

BEUTHE, $M$ et al. (2002) External costs of the Belgian interurban freight traffic: a Network Analysis of their Internalisation. Transportation Research D 7 (2002), pp. 285-301.

BILEN B. ; BILEN-KATIC, B. (1997) Modified pusher tug design for the Danube river. International Shipbuilding Progress, Vol. 44, No. 438 (1997), pp. 127-144.

BILEN B. ; ZERJAL, M. (1999) An optimized propulsive and manoeuvring system for river pushboats. International Conference on Coastal Ships and Inland Waterways. Paper No. 17, London, February 17-18, 1999. 
BINEK, H. ; MÜLLER, E. (1978) Propulsionsversuche mit Schubverbänden auf Begrenzter Wassertiefe. Schiff ; Hafen, vol. 30, No. 11, Jan. 1978. Ensaios de propulsão com comboios de chatas em profundidade restrita. Tradução de Letícia P. Rocco, IPT/DITT (inédita), Agosto 1993.

BLOWMIK, N.G. et al. (1981) The effects of Illinois river traffic on water and sediment input to a side channel. Illinois Institute of Natural Resources. September 1981, $137 \mathrm{p}$.

BROLSMA J. U. et al. (1988) Six-barge pushtow trials. Permanent International Association of Navigation Congress (PIANC), Brussels: Bulletin 1988, No. 62, pp. 21-83.

CATERPILLAR. (1988) Propulsion engine performance data. Caterpillar Engine Division. October 1988.

CENTRAL COMMISSION for the NAVIGATION of the RHINE (2002) Amendment of the Rhine Vessel Inspection Regulations - Chapter 8a: Exhaust and pollutant particle emissions from diesel engines. CCNR, January, 2002.

CHRISTENSEN, F. T. et al. (1991) Accidental limit state ice loads on bridge piers. PIANC, Bulletin No. 72, pp. 15-30, 1991.

CHRISTOPOULOS, B ; LATORRE, R. (1983) River towboat hull and propulsion. Marine Technology, SNAME, vol. 20, No. 3, July 1983, pp. 209-226.

ENGLISH, J. W. (1967) One-dimensional ducted propeller theory: Influence of tip clearance on performance. National Physical Laboratory - Ship Division, Ship Report 94, May 1967.

ERYUSLU, N. E. (1994) Under keel requirements for large vessels in shallow waterways. 28th International Navigation Congress - PIANC, Seville, May 22-27, 1994, Section II, Vol. 2, p. 17-26.

FERREIRA, A. N. (2000) Estudo do efeito de acidentes na hidrovia TietêParaná: Aspectos Preventivos. Dissertação. Escola Politécnica da Universidade de São Paulo. Departamento de Engenharia Naval e Oceânica. São Paulo: 2000, 168p.

FUJII, Y. ; MIZUKI, N. (1998) Design of VTS systems for waterway with bridges : Ship Collision Analysis, Gluver; Olsen (eds). Balkema, Rotterdam, 1998, pp. 177190.

GARCIA, H. A. (2001) Análise dos procedimentos de projeto e desenvolvimento de método para determinação de custos de construção e operação de embarcações fluviais. Tese (Doutorado) - Escola Politécnica da Universidade de São Paulo, Departamento de Engenharia Naval, São Paulo, 2001, 159 p. 
GARCIA, M. H. e al. (1999) Effects of navigation on sediments. $28^{\text {th }}$ Congress of International Association for Hydraulic Research - IAHR, Graz, Austria, 1999, 7 p.

GENT, W. Van ; OOSTERVELD, W. C. (1983) Ducted propeller systems and energy saving. International Symposium on Ship Hydrodynamics and Energy Saving. El Pardo, September 6-9, 1983. Paper No. VI-3, 19 p.

GODOY, P. R. C. ; VIEIRA, A. P. (2000) Hidrovias interiores. Sistema Nacional de Informações sobre Recursos Hídricos (site: www.ana.gov.br).

GRABOWSKI, M. e al. (2000) Risk modelling in distributed, large-scale systems. IEEE Systems, Cybernetics, A, August 2000, 37 p.

GRIGSON, C. (1990) Screws working in behind and prediction of the performance of full scale. Journal of Ship Research, Vol. 34, No. 4, December 1990, pp. 262-282.

GUESNET, T. (1999) Modern concepts in the design of vessels for inland waters. International Conference on Coastal Ships and Inland Waterways. RINA, London: Paper No. 10, 17-18 February, 1999.

HAGER, M. (1994) Considering ecological aspects in the development of inland waterways: a methodology. 28th International Navigation Congress. Permanent International Association of Navigation Congresses (PIANC), Seville: Subject 4, Part 3 , pp. 57-66.

HANSELMAN, D ; LiTTLEFIELD, B. (2003) MATLAB 6: Curso completo. São Paulo, Prentice Hall, 2003. 676 p.

HARVALD, S. A. (1976) Wake and thrust deduction at extreme propeller loadings for a ship running in shallow water. The Royal Institution of Naval Architects. Transactions. Vol. 118, p. 213-233.

HIRATA, K. et al. (1992) Projeto hidrodinâmico de chatas. $14^{\circ}$ Congresso Nacional de Transportes Marítimos, Construção Naval e Offshore, Rio de Janeiro, 5 a 8 de Outubro, 1992.

HIRATA, K. (2000) Manobrabilidade de comboios - testes em semi-escala. $18^{\circ}$ Congresso Nacional de Transportes Marítimos, Construção Naval e Offshore, Rio de Janeiro, 18 a 22 de Setembro, 2000.

INSEL, M. \& HELVACIOGLU, I. H. (1996) Manoeuvrability analysis of double ended ferries in preliminary design. $11^{\text {st }}$ Ship Control Symposium. Southhampton, UK, April 1997.

INSTITUTO DE PESQUISAS TECNOLÓGICAS DO ESTADO DE SÃO PAULO (1970) Ensaio de auto-propulsão com empurrador e chatas fluviais. Agosto, 1970 (Relatório Técnico No. 5.698). 
(1973) Ensaio de auto-propulsão do auto-propelido AP-2 em água profunda e em água rasa. Dezembro, 1973 (Relatório Técnico No. 7.308).

- (1981a) Estudo experimental com modelos de sistemas de lemes de proa. Março, 1981 (Relatório Técnico No. 14.037).

(1981b) Hidrovia Tocantins-Araguaia. Agosto, 1981 (Relatório Técnico No. 16.204).

(1986) Estudos teóricos sobre um quebra-ondas de pneus. Maio, 1986 (Relatório Técnico No. 23.887).

- (1992) Comboio de Pesquisas do Rio Araguaia: Análise do desempenho propulsivo e de manobras - sexta viagem. Abril. 1992 (Relatório Técnico No. 29.925).

- (1993-a) Análise dos resultados dos ensaios de desempenho propulsivo com modelos do Comboio de Pesquisas do Rio Araguaia: Correlação com os resultados em escala Real. IPT/ Divisão de Tecnologia de Transportes. Relatório Técnico No. 31.237. Abril, 1993.

. (1993-b) Comboio de Pesquisas do Rio Araguaia: Análise do desempenho propulsivo e de manobras - oitava viagem. Junho, 1993. (Relatório Técnico No. 31.468).

. (2000) Estimativas de custos de transportes de cargas

fluviais. Divisão de Tecnologia de Transportes. Agrupamento de Hidrovias e Tecnologia Naval. (Relatório Interno - inédito).

INTERNATIONAL ASSOCIATION OF MARINE AIDS TO NAVIGATION AND LIGHTHOUSE AUTHORITIES - IALA (2000). Guidelines on risk management. IALA-AISM. December 2000, 44 p.

INTERNATIONAL MARITIME ORGANIZATION - IMO (2002) Standards for ship manoeuvrability. Report to The Maritime Safety Committee, Annex 3; Annex 4, IMO DE 45/27/Add.1, 24 April 2002.

INTERNATIONAL TOWING TANK CONFERENCE (2002-a) 23rd International Towing Tank Conference. The Manoeuvring Committee. Proceedings, Appendix A - Manoeuvring in shallow and confined waters , Vol. I, pp. 201-234, Venice, Italy, September, 2002.

INTERNATIONAL TOWING TANK CONFERENCE (2002-b) 23rd International Towing Tank Conference. The Specialist Committee. on Speed and Powering Trials. Proceedings, Vol. II, pp. 341-367, Venice, Italy, September, 2002.

ISHERWOOD, R. M. (1973) Wind resistance of merchant ships. Transactions of Royal Institution of Naval Architects. London, 1973. 
JOURNAL OFFICIEL DE LA REPUBLIQUE FRANÇAISE (1991) Navigation intérieure - bateaus de marchandises. Paris, Novembre 1991, 199p.

JUKOLA, H. ; LINDBORG, K. (1999) New applications for azimuth thrusters in coastal and inland shipping. International Conference on Coastal Ships and Inland Waterways. RINA, London: Paper No. 18, 17-18 February, 1999.

KEEVIN, T. M. et al. (2002) Mortality of fish early life stages resulting from hull shear stress associated with passage of commercial navigation traffic. Interim Report for the Upper Mississipi River - Illinois Waterway System Navigation Study ENV Report 35, USACE, Rock Island District, September 2002.

KHATTAB, O. (1999) Design aspects of low wash, high controllability hull forms for inland waterways. International Conference on Coastal Ships and Inland Waterways. RINA, London: Paper No. 14, 17-18 February, 1999.

KITE-POWELL, H. L. et al. (1998) Formulation of a model for ship transit risk: Final project report. Sea Grant College Program. Massachusetts Institute of Technology, MITSG 98-6.

KOLB, A. ; WACKER, M. (1995) Calculation of energy consumption and pollutant emissions on freight transport routes. The Science of the Total Environmental 169 (1995), pp. 283-288.

KOSTER, IR. J. (1975) Push tows in canals. Rykswarwestaat Communications, No. 21, The Hague: Delft Hydraulics Laboratory, 1975.

LACKENBY, H. (1963) Note on effect of shallow water on ship resistance. Brithish Shipbuilding Research Association BSRA Report No. 377, 1963.

LAP, A. J. W. (1957) Fundamentals of ship resistance and propulsion. International Shipbuilding Progress, Vol. 4, No. 29: pp. 43-58, January 1957.

LATORRE, R.; ASHCROFT, F. (1981) Recent developments in barge design, towing and pushing. Marine Technology, SNAME, Vol. 18, No. 1, January 1981, pp. 10-21.

LATORRE, R. \& DUNOW, H. H. (1981) Improvement of river towboat propulsion: translations of selected German and Russian technical articles. Department of Naval Architecture and Marine Engineering, Report No. 243, University of Michigan, Ann Arbor, November, 1981.

LATORRE, R. et al. (1982) Improvement of inland waterway vessel and barge tow performance: translations of selected Chinese, German and Russian technical articles. Department of Naval Architecture and Marine Engineering, Report No. 249, University of Michigan, Ann Arbor, September 1982. 
LATORRE, R. (1985) Shallow river pushboat preliminary design. Journal of Waterway, Port, Coastal and Ocean Engineering, Vol. 111, No. 4, July, 1985, pp. 678-692.

LEWIS, E.V. (1988) Principles of naval architecture Vol. II - Resistance, Propulsion and Vibration. The Society Of Naval Architects and Marine Engineers SNAME, Jersey City, NJ, 1988.

LIN, H. L. et al. (1998) Physical risk analysis of ship grounding. Massachusetts Institute of Technology. Design Laboratory Memorandum 98-10, December, 1998.

LOVER, E. P. (1969) Stopping of ships using propellers. 12th - International Towing Tank Conference (ITTC), Proceedings, Rome, September 1969.

LUTHRA, G. (1974) Investigation of the wake distribution of a towboat pushing a barge train. Hansa, Vol. 111, No. 18, September, 1974, pp. 1515-1521. English translation: Latorre \& Dunow (1981).

LUTHRA, G. (1979) Effect of profile thickness and angle of attack of flanking rudders in pusher tugs on thrust deduction and propulsion power. Shiff Und Hafen, Heft 10/1979, 6 p. English translation: Latorre et al. (1982).

LUTHRA, G. (1982) Systematische ermittlung und zusammenstellung der charakteristichen steuerkenngrö en von binnenschiffen und schubverbänden. Hansa, Vol. 119, No. 7, April, 1982.

MARSHAL, J. L. J. et al. (1996) An empirical formula to estimate the resistance of a convoy in a restricted waterway. Journal of Ship Research, Vol. 40, No. 2, SNAME, June 1996, pp. 107-111.

MARTIN, S. K. (1997) Physical model studies for riprap design of tow-induced forces. U.S Army Corps of Engineers. Waterways Experiment Station. Technical Report CHL-97-7. Washington, DC, April 1997, 260 p.

MATSUNAGA, M. (1993) Methods of predicting ship manoeuvrability in deep and shallow waters as a function of loading condition. Nippon Kiokai (NK) Technical Bulletin, 1993, pp. 51-59.

MAYNORD, S. T. (2000a) Physical forces near commercial tows. Interim Report for the Upper Mississipi River - Illinois Waterway System Navigation Study - ENV Report 19, USACE, Rock Island District, March 2000, 73 p.

MAYNORD, S. T. (2000b) Inflow zone and discharge through propeller jets. Interim Report for the Upper Mississipi River - Illinois Waterway System Navigation Study - ENV Report 25, USACE, Rock Island District, September 2000, 73 p.

MILLWARD, A. (1990). A preliminary design method for the prediction of squat in shallow water. Marine Technology, 27(1), pp. 10-19, January 1990. 
MWM (2000). MWM MOTORES DIESEL LTDA. Série 229: Dados Técnicos. 2000 .

NORRBIN, N. H. (1996) The effects of flow confinement and asymmetry on a ship in a fairway passage. Workshop on Ship Squat in Restricted Waters, Panel H10 (Ship Controllability), Hydrodynamics Committee, SNAME, July 1996, pp. 87-93.

NOVAES, A.G.N. (1975) Pesquisa operacional e transportes: Modelos probabilísticos. McGraw Hill do Brasil, São Paulo, 1975, 239p.

OGAWA, A. ; KASAI, H. (1978) On the mathematical model of manoeuvring motion of ships. International Shipbuilding Progress, Rotterdam, V. 25, No. 292, pp. 306-319, December 1978.

OHTSU, K., SHOJI, K. ; OKAZAKI, T. (1996) Minimum-time maneuvering of a ship, with wind disturbances. Control Engineering Practice, London: Vol. 4, No. 3, pp. 385-392, 1996.

OLSON, C.R. (1955) Effects of Various Linkage Ratios on the Free-Stream Hydrodynamic Characteristics of All-Movable Flapped Rudder. Navy Department, The David W. Taylor Model Basin. NSRDC Report 991, Washington D.C., September 1955, 21 p.

OTAY, E.N. ; TAN, B. (1999) Stochastic modeling of tanker traffic through narrow waterways. $1^{\text {st }}$ International Conference in Oil Spils in The Mediterranean and Black Sea Regions. 15-18 September, 1998, Istambul, pp. 85-96.

PADOVEZI, C. D.; GIRALDO, A. (1986) Utilização de combustíveis alternativos em um comboio fluvial. IPT Comunicação Técnica No. 1651. 12 p., 1986.

PADOVEZI, C. D. (1990) Ensaios em escala real do Comboio de Pesquisas do Rio Araguaia. $13^{\circ}$ Congresso Nacional de Transportes Marítimos, Construção Naval e Offshore, Rio de Janeiro, Outubro, 1990.

(1994) Propulsores de embarcações fluviais de carga. $15^{\circ}$ Congresso Nacional de Transportes Marítimos, Construção Naval e Offshore, Rio de Janeiro, Outubro, 1994.

(1997) Aplicação de resultados de escala real no projeto de hélices de embarcações fluviais. Dissertação (Mestrado). Escola Politécnica da Universidade de São Paulo. Departamento de Engenharia Naval e Oceânica. São Paulo: 1997, 87 p.

(2002) Potência mínima para garantia da segurança de operação de comboios fluviais. $19^{\circ}$ Congresso Nacional de Transportes Marítimos, Construção Naval e Offshore, Rio de Janeiro, Outubro, 2002. 
PADOVEZI, C. D. ; CALTABELOTI, O. (2001) Sistema flutuante de proteção de pilares de pontes junto a rotas de navegação $2^{\circ}$ Seminário Nacional de Transporte Hidroviário Interior - Jau (SP), SOBENA - Sociedade Brasileira de Engenharia Naval, Agosto de 2001.

PEDERSEN, P. T. ; ZHANG, S. (1999) Collision analysis for MS DEXTRA. Safer Euroro Spring Meeting, Nantes, April 1999.

PERMANENT INTERNATIONAL ASSOCIATION OF NAVIGATION CONGRESSES - PIANC (1997) Approach channels, a guide for design. Final report of the Joint Working Group PIANC-IAPH. Supplement to Bulletin No. 95, June 1997.

PLANCHAR, R. A. (1990) Economie dês transports et logistique. Ecole dês Hautes Etudes Commerciales de Liege - Institut Supérieur Universitaire de Gestion, Fevrier 1990, 311 p.

RAWSON et al. (1998) Assessing the environmental performance of tankers in accidental grounding and collision. Society of Naval Architects and Marine Engineers - SNAME Transactions, Vol. 106, 1998, pp. 41-58.

ROELEVEN, D. et al. (1995) Inland waterway transport: modelling the probability of accidents. Safety Science 19 (1995), pp. 191-202.

ROLLS-ROYCE (2002) Tugs, workboats and coastal ferries. Catálogo, 2002, 9 p.

SLOB, W. (1998) Determination on risks on inland waterways. Journal of Hazardous Materials. 61 (1998), pp. 363-370.

SÖLVE, T. (1990) Safety tolerances for ship navigation in narrow inland waterways. Practical Application on Trollhätte Canal, Sweden. 27th International Navigation Congress. Permanent International Association of Navigation Congresses (PIANC). Osaka: S.I. - 1, pp. 95-100, May 1990.

SORENSEN, R. M. (1997) Prediction of vessel-generation waves with references to vessels common to the upper Mississipi river system. Interim Report for the Upper Mississipi River - Illinois Waterway System Navigation Study - ENV Report 4, USACE, Rock Island District, December 1997, 50 p.

STEWART, R. M. et al. (1997) Flume study investigation of the direct impacts of navigation-generated waves on submerged aquatic macrophytes in the upper Mississipi river. Interim Report for the Upper Mississipi River - Illinois Waterway System Navigation Study - ENV Report 1, USACE, Rock Island District, September 1997, 62 p.

TALLEY, W. K. (1999) Determinants of the property damage costs of tanker accidents. Transportation Research Part D 4 (1999), pp. 413-426. 
THE GLOSTEN ASSOCIATES (2003) Supplemental Monte Carlo Navigation Simulation Study. Technical Memorandum DOT\&PF Project 67698. Gravina Access Project. July, 2003, 29 p.

TUCK, E. O. (1966) Shallow water flows past slender bodies. Journal of Fluid Mechanics, 26(1), pp. 81-95, 1966.

UNITED STATES ENVIRONMENTAL PROTECTION AGENCY - US-EPA (1999) Indicators of the environmental impacts of transportation, 2. ed. Washington: EPA 230-R-99-01, October 1999.

USACE (1984) Shore protection manual. U.S. Army Engineer Waterways Experiment Station. Coastal Engineering Research Center, 1984.

VOLKER, H. (1965) The problems of pushed cargo-vessels on the upper Danube. 21th International Navigation Congress. Permanent International Association of Navigation Congresses (PIANC). Stockolm: Section I. Volume 3, p. 33-45.

WALKER, D. et al. (1997) Hydrodynamic load on ice-class propellers during propeller-ice interaction. Journal of Marine Science and Technology, SNAJ. 2, pp. 12-20. 1997.

WERF, K. van der (1999) INBISHIP Innovation in inland shipping. International Conference on Coastal Ships and Inland Waterways. RINA, London: Paper No. 12, 17-18 February, 1999.

WHITNEY, M. W. et al. (1996) Barge collision design of highway bridges. Journal of Highway Bridges, ASCE, Vol.1, No. 2, May 1996, pp. 47-58.

WILDENHAHN, E. (1994) Ecological aspects of the transport system waterway/barge. 28th International Navigation Congress. Permanent International Association of Navigation Congresses (PIANC). Seville: S.I. - 4, pp. 44-52, 1994. 
ANEXO A

HIDROVIAS BRASILEIRAS 
O Brasil tem um grande potencial para utilização do transporte hidroviário. Muitos rios apresentam características físicas e localizações adequadas ao transporte de cargas e de passageiros. Há, contudo, historicamente, uma sub-utilização de todo o potencial existente.

Na Amazônia, os grandes rios são, praticamente, a única via de transporte, que, aos poucos, vai sendo utilizada de forma competente. Outros rios, como o Paraguai, o baixo Paraná, o Madeira e a Lagoa dos Patos apresentam condições naturais tão satisfatórias que não exigiram grandes investimentos para tornarem-se hidrovias economicamente viáveis. Rios como o Tietê, o São Francisco, o Jacuí e o Taquari, com barragens, dependeram da construção de eclusas para a continuidade do tráfego hidroviário. Alguns rios, também com barragens, mas que não tiveram eclusas construídas, como o rio Grande, na divisa de São Paulo e Minas Gerais, estão impedidos de serem utilizados como hidrovias de longo percurso; podem prestar-se apenas à utilização para transportes regionais, restritos dentro de um mesmo reservatório. Os projetos mais recentes de hidrovias, envolvendo rios com localizações privilegiadas para escoamento de produção agrícola, como o rio Araguaia e o Tapajós, têm sofrido questionamentos de ordem ambiental, o que tem retardado a sua implantação.

Os rios brasileiros em corrente livre apresentam baixa declividade (entre 1,5 e 3,5 $\mathrm{cm} / \mathrm{km}$ ), particularmente nas regiões centro-oeste, norte e nordeste. Trechos de rios que apresentavam declividades mais altas (médio e baixo Tietê, médio e alto Paraná, baixo São Francisco, Jacuí e Taquari), foram regularizados por meio de construções de barragens, quase sempre para geração de energia elétrica.

Grande número de rios não apresenta restrições à navegação (Amazonas, Solimões, Madeira, trechos de rios regularizados como o Tocantins, o Tietê e o alto Paraná). Uns poucos rios têm problemas nos períodos de águas altas, casos do Jacuí e do Taquari, quando há grandes velocidades de correntes e pequenos "tirantes de ar" (distância da água ao elemento inferior de uma estrutura fixa sobre o rio) em pontes e em eclusas. Contudo, muitos rios apresentam restrições à navegação em época de águas rasas (Paraguai, baixo Paraná, Araguaia, Parnaíba, Tapajós, São Francisco, 
etc.). O período de águas baixas nestes rios ocorre entre os meses de junho e de outubro (ou novembro), exigindo maiores atenções para a navegação. Há casos em que os números de chatas dos comboios devem ser reduzidos, assim como devem ser reduzidos os calados de operação, para fazer frente à redução de profundidade e ao aumento de meandros dos canais de navegação.

\section{Hidrovia do Amazonas}

Os rios Amazonas e Solimões constituem o maior volume de águas doce do mundo. A navegação por estes rios se faz sem restrições, atingindo os portos de Letícia na Colômbia e de Iquitos no Peru, este a cerca de $3.600 \mathrm{~km}$ da foz do rio.

Os seus principais portos, Manaus, Santarém e Itacoatiara podem receber navios de até 60.000 tpb. Da foz do rio até Manaus, a profundidade média é de 13,5 metros. No trecho Manaus a Tabatinga, divisa do Brasil, a profundidade mínima é de 7 metros.

Nesta hidrovia são utilizados poucos comboios, havendo predominância de pequenas embarcações para transporte de carga geral e embarcações fluviomarítimas de médio porte para transporte de granéis sólidos e líquidos. Os comboios existentes são principalmente formados por um empurrador e uma chata para transporte de carretas entre Belém e Manaus.

Principais cargas: combustíveis, carga geral, GLP.

\section{Hidrovia do Madeira}

O rio Madeira é navegável numa extensão de $1.056 \mathrm{~km}$, entre Porto Velho e sua foz, no rio Amazonas, permitindo, mesmo na época de estiagem, a navegação de grandes comboios, com até 18.000 t. Os investimentos na hidrovia compreendem dragagens, derrocamentos, balizamento e sinalização. Atualmente, cerca de dois milhões de toneladas por ano de cargas são transportados pelo rio Madeira. Há uma tendência de crescimento do volume transportado.

A companhia Hermasa possui os únicos comboios desta hidrovia, transportando soja de Porto Velho a Itacoatiara: 30 chatas e 3 empurradores, cada um deles, com dois 
propulsores azimutais. Outras embarcações estão em processo de aquisição. Embarcações automotoras realizam o transporte de, principalmente, carga geral e combustíveis, entre Porto Velho e Manaus.

Em alguns trechos, o rio Madeira exige manobras em pequenos raios de curvaturas, o que causa aumento de tempo de viagem. Entre os períodos de cheia e de estiagem, há variações de nível d'água de até 14 metros. Na época de cheias, as velocidades de corrente são relativamente elevadas e há a presença de troncos flutuando descendo o rio, aumentando a probabilidade de choques com o casco do comboio e, pior, com os propulsores azimutais.

Principais cargas: soja, carga geral, combustíveis, GLP.

\section{Hidrovia do Guamá-Capim}

A hidrovia Guamá-Capim é um importante corredor de transporte de minérios provenientes, na sua maioria, das ricas jazidas de caulim e de bauxita, além de servir ao transporte de produção de pólos agropecuários em formação, especialmente na região de Paragominas. As maiores restrições à navegação ocorrem em alguns trechos críticos do rio Capim, no período de águas baixas. O comboio-tipo da hidrovia é constituído por quatro chatas, na formação duas a duas.

Principais cargas: caulim, madeira, carga geral.

\section{Hidrovia do São Francisco}

O rio São Francisco é navegável em 1.371 km, entre Pirapora (MG), Juazeiro (BA) e Petrolina (PE), com uma profundidade limitada a cerca de $1,5 \mathrm{~m}$, durante o período de estiagem ou águas baixas (agosto a novembro). Sem saída para o Atlântico, o rio São Francisco tem seu aproveitamento integrado ao sistema rodo-ferroviário da região. A partir da implantação do sistema multimodal, o escoamento da produção agrícola do oeste da Bahia, com foco na cidade de Barreiras, banhada por um dos seus principais afluentes, o rio Grande, é realizado por rodovia até a cidade de Ibotirama na margem do São Francisco, descendo o rio pelo transporte hidroviário até Juazeiro/Petrolina, e deste, por ferrovia, para o Porto de Aratú (BA). No 
quilômetro 42 acima de Juazeiro/Petrolina, situa-se a barragem, com eclusa, de Sobradinho. A movimentação anual fica em torno de 60.000 tonelada/ano de cargas gerais, soja, milho, farelo de soja, etc.

\section{Hidrovia Tietê-Paraná}

A hidrovia Tietê-Paraná permite a navegação entre Conchas no rio Tietê (SP) e São Simão (GO), no rio Paranaíba, e até Itaipu, no tramo sul do rio Paraná. O trecho hidroviário atualmente mais utilizado, de São Simão (GO) até Pederneiras (SP), tem um percurso de $640 \mathrm{~km}$. O percurso de Hernandárias (Paraguai) até Pederneiras (SP) é de $1.120 \mathrm{~km}$.

A hidrovia movimenta mais de um milhão e meio de toneladas de grãos/ano, a uma distância média de $700 \mathrm{~km}$. Se forem computadas as cargas de pequena distância como areia, cascalho e cana de açúcar, a movimentação no rio Tietê ultrapassa 4 milhões de toneladas anuais.

A Hidrovia Tietê-Paraná e mais os trechos médio e baixo dos rios Paraná e Paraguai, em territórios argentino e paraguaio, formam uma rede hidroviária de mais de 7 mil quilômetros, a chamada Hidrovia do Mercosul. O único ponto de descontinuidade, a Barragem de Itaipú, ainda sem eclusas, exige um transbordo de carga em uma extensão de cerca de 40 quilômetros por via rodoviária.

Principais cargas: soja, farelo de soja, óleo vegetal, álcool, milho.

\section{Hidrovia do Paraguai}

Essa hidrovia compõe um sistema de transporte fluvial de utilização tradicional, em condições naturais, que conecta o interior da América do Sul com os portos de águas profundas no curso inferior do rio Paraná e no rio da Prata. Tem $3.442 \mathrm{~km}$ de extensão, desde Cáceres até o seu final, no estuário do rio da Prata. No território brasileiro, a hidrovia percorre $1.278 \mathrm{~km}$ e tem como principais portos: Cáceres, Corumbá e Ladário, além de terminais privados com expressiva movimentação de carga. Entre 1998 e 2000 foram movimentadas mais de 6 milhões de toneladas de cargas, apenas no trecho brasileiro. 
A hidrovia Paraguai pode ser dividida em três segmentos distintos, devido às suas características físicas:

a) Trecho Corumbá-Cáceres (ou Morrinhos) - é o trecho mais crítico, com raios de curvaturas reduzidos e grandes restrições de profundidades. Morrinhos é uma alternativa a Cáceres como terminal final, apresentando a vantagem de evitar os piores estirões para navegação do trecho. Os comboios utilizados têm menor porte (de quatro ou seis chatas), com calado assegurado de 1,5 m. Em cerca de 3 meses ao ano, a navegação no trecho sofre limitações.

b) Trecho de Corumbá-Assunção (Paraguai), onde trafegam comboios com formação 4 x 4, compostos por chatas de $60 \mathrm{~m}$ de comprimento e $12 \mathrm{~m}$ de largura, com calado assegurado de 2,6 m, capazes de transportar 20.000 a 25.000 toneladas de cargas.

c) Trecho a jusante de Assunção, com possibilidade de tráfego de comboios maiores, atualmente navegando com 20 chatas (formação 5 x 4), deslocamento total de 31.000t, com empurrador de 5.000 HP.

As principais cargas transportadas no trecho brasileiro são: minério de ferro, minério de manganês e soja.

\section{Hidrovias do Sul}

Fazem parte das Hidrovias do Sul as Lagoas dos Patos e Mirim, o canal de São Gonçalo que liga o rio Jacuí a seu afluente, Taquari, e a uma série de rios menores como Caí, Sinos e Gravataí, que constituem o estuário do Guaíba. O rio Jacuí foi canalizado com a construção de três barragens com eclusas, resultando em uma extensão de $300 \mathrm{~km}$ com calado permitido de $2,5 \mathrm{~m}$. No rio Taquari foi implantada a barragem com eclusa de Bom Retiro do Sul, dando acesso ao Porto Fluvial de Estrela, para embarcações de 2,5 m de calado. As embarcações que freqüentam esta hidrovia são automotoras com capacidade média de 3.000 toneladas. No porto de Estrela o movimento chega a 650.000 t/ano. No passado, movimentou 1 milhão de 
tonelada/ano. Na Lagoa dos Patos a navegação é também realizada por embarcações fluviomarítimas com até $5,10 \mathrm{~m}$ de calado, em um percurso de $250 \mathrm{~km}$ entre as cidades de Rio Grande (porto marítimo) e Porto Alegre.

Principais cargas: carga geral, carvão, óleo vegetal, farelo de soja, milho.

\section{Hidrovias em implantação}

Estão sendo adotadas medidas de implantação das hidrovias do Tocantins-Araguaia e do Tapajós, importantes para o escoamento da produção agrícola da região CentroOeste aos portos do norte do País, com grandes reduções de custos. Estas duas hidrovias têm a sua implantação atrasada por problemas nos respectivos processos de licenciamento ambiental.

O rio Araguaia e o rio Tapajós são rios em corrente livre, enquanto que o rio Tocantins já apresenta barragens, constituindo grandes reservatórios (Tucuruí, Lajeado).

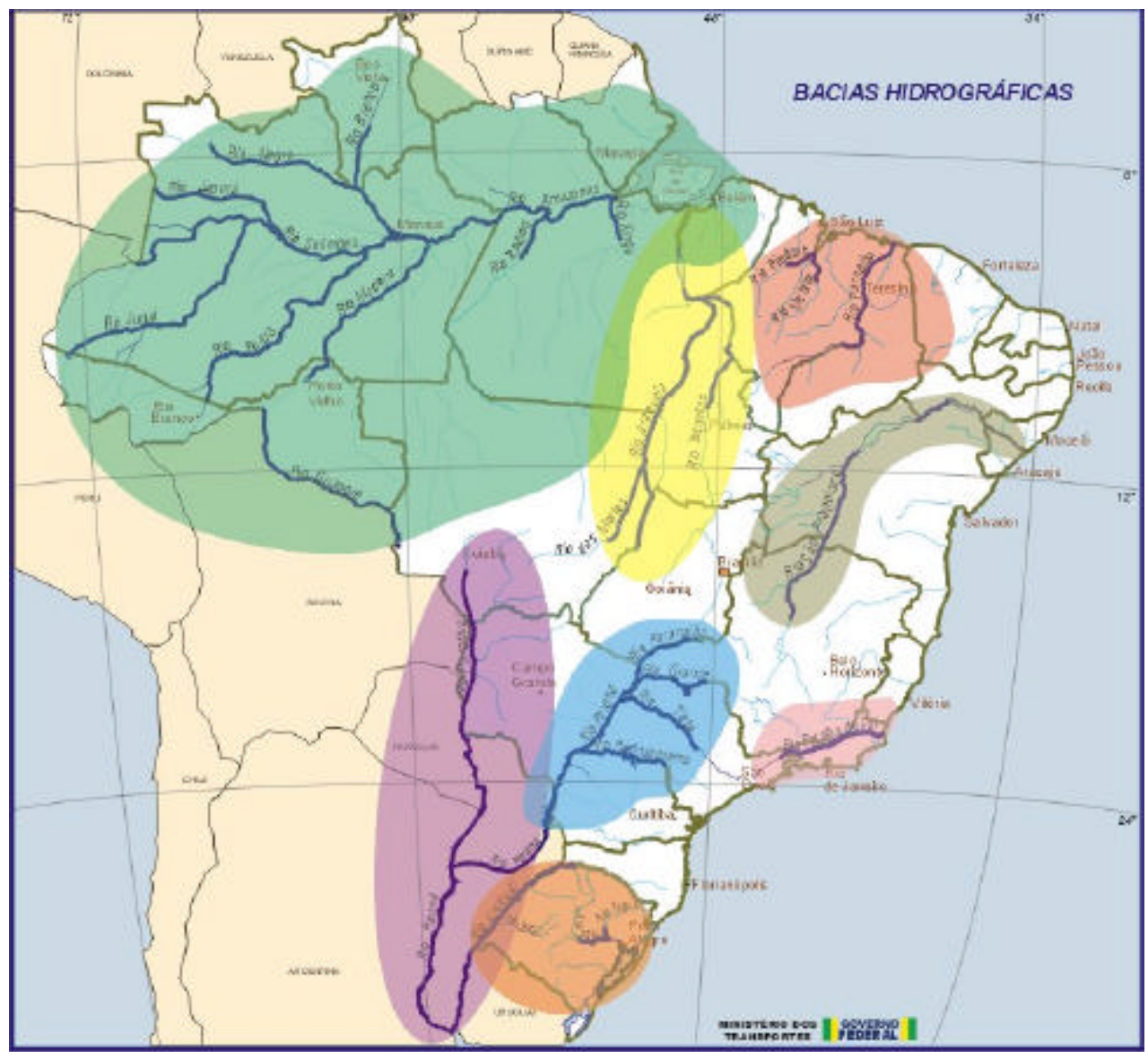

Figura A.1 - Bacias Hidrográficas do Brasil (Ministério dos Transportes) 
Tabela A.1 - Quantidade de cargas transportadas em hidrovias nos anos de 1998, 1999 e 2000

\begin{tabular}{|c|c|c|c|c|}
\hline HIDROVIAS & $\begin{array}{l}\text { Movimentação } \\
1998 \text { (t) }\end{array}$ & $\begin{array}{c}\text { Movimentação } \\
1999(t)\end{array}$ & $\begin{array}{l}\text { Movimentação } \\
2000(t)\end{array}$ & $\begin{array}{c}\text { Variação no } \\
\text { Triênio } 1998 \text { / } \\
2000 \\
\end{array}$ \\
\hline \multicolumn{5}{|c|}{ Bacia Amazônica Amazônia Ocidental } \\
\hline Madeira & 1.454 .716 & 1.418 .069 & 1.955 .471 & $34,42 \%$ \\
\hline Solimões & 1.581 .940 & 1.629 .555 & 2.291 .165 & $44,83 \%$ \\
\hline \multicolumn{5}{|c|}{ Bacia Amazônica Amazônia Oriental } \\
\hline Amazonas & 13.075 .812 & 14.839 .447 & 12.997 .779 & $-0,60 \%$ \\
\hline Guamá e Capim & 318.263 & 539.984 & 720.751 & $126,46 \%$ \\
\hline \multicolumn{5}{|l|}{ Bacia do Nordeste } \\
\hline Parnaíba & - & - & 45.169 & \\
\hline Rios Estaduais & - & - & 142.011 & - \\
\hline \multicolumn{5}{|c|}{ Bacia do São Francisco } \\
\hline $\begin{array}{c}\text { São Francisco e } \\
\text { Grande }\end{array}$ & 47.238 & 65.610 & 58.766 & $24,40 \%$ \\
\hline \multicolumn{5}{|c|}{ Bacia do Tocantins Araguaia } \\
\hline $\begin{array}{c}\text { Araguaia, Mortes e } \\
\text { Tocantins }\end{array}$ & 2.400 & 2.400 & 2.400 & $0,00 \%$ \\
\hline \multicolumn{5}{|l|}{ Bacia do Paraguai } \\
\hline Paraguai & 2.155 .574 & 2.053 .449 & 1.911 .326 & $-11,33 \%$ \\
\hline \multicolumn{5}{|l|}{ Bacia do Tietê Paraná } \\
\hline Tietê e Paraná & 1.722 .677 & 1.740 .159 & 1.531 .920 & $-11,07 \%$ \\
\hline \multicolumn{5}{|l|}{ Bacia do Sudeste } \\
\hline $\begin{array}{l}\text { Jacuí, Taquari e } \\
\text { Lagoa dos Patos }\end{array}$ & 544.663 & 503.418 & 407.139 & $-25,25 \%$ \\
\hline Total & 20.903.283 & 22.792 .091 & 22.063.897 & $5,55 \%$ \\
\hline Fonte: Administrações das 1 & Irovias $(M T)$ & & & \\
\hline
\end{tabular}


Tabela A.2 - Principais rios navegáveis nas suas respectivas bacias

\begin{tabular}{|c|c|c|c|}
\hline BACIA E RIO & TRECHO NAVEGÁVEL & $\begin{array}{c}\text { EXTENSÃO } \\
(\mathbf{k m})\end{array}$ & $\begin{array}{c}\text { Profundidade } \\
\text { mínima } 90 \% \\
\text { do tempo }(\mathrm{m})\end{array}$ \\
\hline \multicolumn{4}{|l|}{ Bacia AMAZÔNICA } \\
\hline \multirow[t]{2}{*}{$\begin{array}{l}\text { Amazonas / } \\
\text { Solimões }\end{array}$} & Foz - Manaus & 1.488 & 6,90 \\
\hline & Manaus - Benjamim Constant & 1.620 & 4,50 \\
\hline \multirow[t]{3}{*}{ Pará } & Foz - Baía das Bocas & 316 & 12,00 \\
\hline & $\begin{array}{l}\text { Estr. de Boiuçu - Furos do } \\
\text { Tajapuru, Limão e Ituquara }\end{array}$ & 154 & 6,50 \\
\hline & $\begin{array}{l}\text { Estreito de Breves - Furo do } \\
\text { Mucujubim }\end{array}$ & 84 & 8,00 \\
\hline \multirow[t]{2}{*}{ Capim } & Foz - Santana & 53 & 1,50 \\
\hline & Santana - $200 \mathrm{~km}$ montante & 200 & 1,20 \\
\hline Guamá & Foz-Foz do rio Capim & 112 & 2,00 \\
\hline Madeira & Foz - Porto Velho & 1.100 & 2,10 \\
\hline \multirow[t]{3}{*}{ Tapajós } & Santarém - Cururu & 35 & 15,00 \\
\hline & Cururu - Itaituba & 245 & 2,50 \\
\hline & Itaituba - São Luís & 47 & 1,70 \\
\hline Negro & Foz - Cucuí & 1.160 & 2,40 \\
\hline \multirow[t]{2}{*}{ Trombetas } & Foz - Oriximiná & 30 & 2,10 \\
\hline & Oriximiná - Porteira & 230 & 1,50 \\
\hline \multirow{9}{*}{$\begin{array}{l}\text { Bacia TOCANTINS } \\
\text { Tocantins }\end{array}$} & & & \\
\hline & Foz - Cametá & 60 & 5,00 \\
\hline & Cametá - Tucuruí & 190 & 3,00 \\
\hline & Tucuruí - Itupiranga & 210 & 1,60 \\
\hline & Itupiranga - S. João do Araguaia & 95 & 0,90 \\
\hline & S. João do Araguaia - Imperatriz & 190 & 1,50 \\
\hline & Imperatriz - Tocantinópolis & 100 & (1) \\
\hline & Tocantinópolis - Miracema & 500 & 1,00 \\
\hline & $\begin{array}{l}\text { Miracema - Confluência } \\
\text { Maranhão/Pará }\end{array}$ & 390 & (1) \\
\hline \multirow[t]{4}{*}{ Araguaia } & Confluência Tocantins - Sta Isabel & 165 & 1,10 \\
\hline & Santa Isabel - Xambioá & 63 & (1) \\
\hline & Xambioá - Conceição do Araguaia & 276 & 0,70 \\
\hline & $\begin{array}{l}\text { Conceição do Araguaia - Barra do } \\
\text { Garças }\end{array}$ & 1.194 & 0,90 \\
\hline \multirow{9}{*}{$\begin{array}{l}\text { Mortes } \\
\text { Bacia do SÃO } \\
\text { FRANCISCO } \\
\text { São Francisco }\end{array}$} & Foz - Foz do Pindaíba & 150 & 1,00 \\
\hline & Foz - Piranhas & 208 & 2,50 \\
\hline & Piranhas - Itaparica & 106 & $\ldots$ \\
\hline & Itaparica - Boa Vista & 296 & $\cdots$ \\
\hline & Boa Vista - Juazeiro & 150 & (1) \\
\hline & Juazeiro - Pirapora & 1.290 & 1,50 \\
\hline & Pirapora - Três Marias & 140 & \\
\hline & Remanso de Três Marias & 150 & 2,10 \\
\hline & $\begin{array}{l}\text { Final do Remanso de Três Marias- } \\
\text { lquatama }\end{array}$ & 190 & (1) \\
\hline \multirow[t]{2}{*}{ Grande } & Foz - Campo Largo & 250 & 2,00 \\
\hline & Campo Largo - Barreiras & 116 & 1,00 \\
\hline
\end{tabular}


Tabela A.2 - Principais rios navegáveis nas suas respectivas bacias (conclusão)

\begin{tabular}{|c|c|c|c|}
\hline BACIA E RIO & TRECHO NAVEGÁVEL & $\begin{array}{l}\text { EXTENSÃO } \\
(\mathbf{k m})\end{array}$ & $\begin{array}{c}\text { Profundidade } \\
\text { mínima } 90 \% \\
\text { do tempo }(\mathrm{m})\end{array}$ \\
\hline \multirow{5}{*}{$\begin{array}{l}\text { Bacia do PARANÁ } \\
\text { Paraná }\end{array}$} & & & \\
\hline & Foz do Iguaçú - Itaipu & 29 & 2,40 \\
\hline & Itaipu - Jupiá & 657 & 1,90 \\
\hline & Jupiá - Ilha Solteira & 54 & 2,40 \\
\hline & Ilha Solteira - Paranaíba Grande & 68 & 2,40 \\
\hline Grande & Foz - Água Vermelha & 59 & 2,10 \\
\hline Parnaíba & Foz - Canal de São Simão & 180 & 2,10 \\
\hline Tietê & Foz - Laras & 585 & 3,00 \\
\hline Piracicaba & $\begin{array}{l}\text { Foz - } 22 \mathrm{~km} \text { montante (Remanso } \\
\text { de Barra Bonita) }\end{array}$ & 22 & 3,00 \\
\hline \multicolumn{4}{|l|}{$\begin{array}{l}\text { Bacia do } \\
\text { PARAGUAI }\end{array}$} \\
\hline Paraguai & Foz Apa - Corumbá & 603 & 1,50 \\
\hline & Corumbá - Cáceres & 720 & 1,50 \\
\hline & Cáceres - Barra Bugres & 370 & (1) \\
\hline \multicolumn{4}{|l|}{$\begin{array}{l}\text { RIOS DO } \\
\text { NORDESTE }\end{array}$} \\
\hline \multirow[t]{4}{*}{ Mearim } & Foz - Barra do Ipixuna & 216 & 2,00 \\
\hline & Barra do Ipixuna - Pedreiras & 188 & 1,50 \\
\hline & Pedreiras - Uchoa & 210 & 0,80 \\
\hline & Uchoa - Barra do Corda & 31 & (1) \\
\hline \multirow[t]{5}{*}{ Pindaré } & Foz - Pindaré-Mirim & 178 & 2,50 \\
\hline & Pindaré-Mirim - Santa Inês & 39 & 2,00 \\
\hline & Santa Inês - Rio Caru & 112 & 1,00 \\
\hline & Rio Caru - Porto Boa Vista & 40 & 0,80 \\
\hline & Porto Boa Vista - Buriticupu & 87 & (1) \\
\hline \multirow[t]{4}{*}{ Parnaíba } & Foz - Floriano & 641 & 0,80 \\
\hline & $\begin{array}{l}\text { Floriano - Guadalupe (Barragem } \\
\text { de Boa Esperança) }\end{array}$ & 75 & 1,00 \\
\hline & $\begin{array}{l}\text { Remanso da Barragem de Boa } \\
\text { Esperanca }\end{array}$ & 155 & 3,00 \\
\hline & Uruçui - Santa Filomena & 364 & 0,80 \\
\hline \multirow{2}{*}{$\begin{array}{l}\text { Jequitinhonha ou } \\
\text { Belmonte }\end{array}$} & Foz - Salto Grande & 130 & 2,80 \\
\hline & Salto Grande - Itabepi & 484 & 1,50 \\
\hline \multicolumn{4}{|l|}{ RIOS DO SUL } \\
\hline Lagoa dos Patos & Itapuã - Rio Grande & 250 & 5,80 \\
\hline Guaíba & Porto Alegre - Itapuã & 50 & 5,80 \\
\hline \multirow[t]{5}{*}{ Jacuí } & P. Alegre - Largo Santa Cruz & 36 & 4,00 \\
\hline & Largo Santa Cruz - Col. Penal & 7 & 3,50 \\
\hline & Col. Penal - Barra do Vacacaí & 226 & 3,00 \\
\hline & $\begin{array}{l}\text { Barra do Vacacaí - Cachoeira Pau } \\
\text { a Pique }\end{array}$ & 22 & 1,30 \\
\hline & $\begin{array}{l}\text { Cachoeira Pau a Pique - 10 Lto do } \\
\text { Monjoleiro }\end{array}$ & 8 & 1,00 \\
\hline Taquari & Foz - Arroio do Meio & 100 & 3,00 \\
\hline
\end{tabular}

FONTE: DP/ MT.

(1) Navegável somente nas cheias. 
ANEXO B

UTILIZAÇÃO DE DADOS EXPERIMENTAIS 


\section{B.1 Dados relativos à resistência ao avanço e potências}

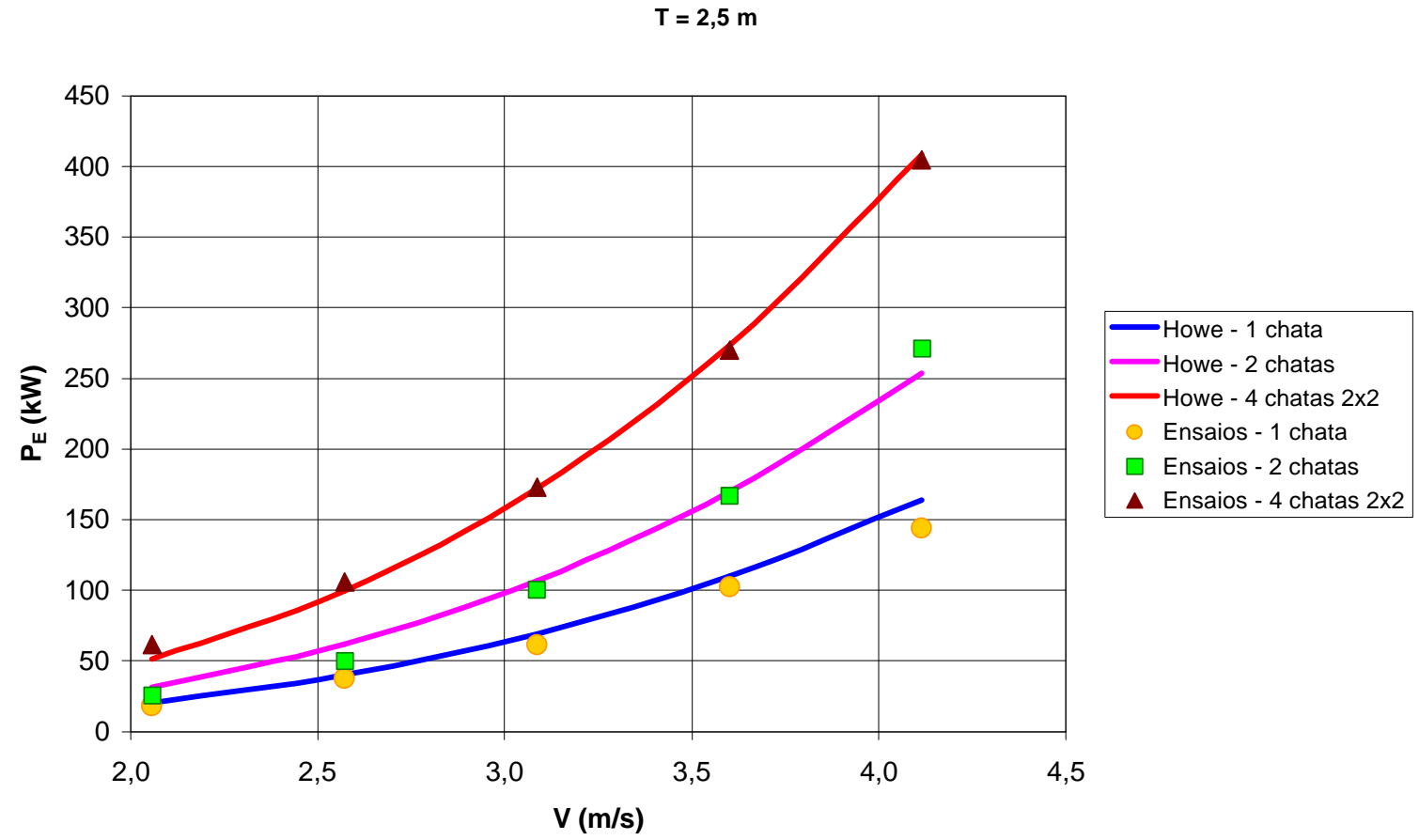

Figura B.1 - Ajuste dos valores de F da formulação de Howe com os ensaios com modelos em escala reduzida (IPT, 1970) - valores de F indicados na Tabela B.1

Tabela B.1 - Valores do Fator F da Formulação de Howe, Obtidos a Partir de Comparação com Resultados de Ensaios em Tanque de Provas do IPT

\begin{tabular}{|l|c|c|}
\hline & \multicolumn{2}{|c|}{ F } \\
\hline condição & IPT (1993-a) & IPT(1970) \\
\hline Uma chata carregada & 0,040 & 0,040 \\
\hline Duas chatas carregadas em linha & 0,045 & 0,050 \\
\hline Duas chatas carregadas em paralelo & 0,033 & \\
\hline Quatro chatas $(2 \times 2)$ & & 0,036 \\
\hline
\end{tabular}




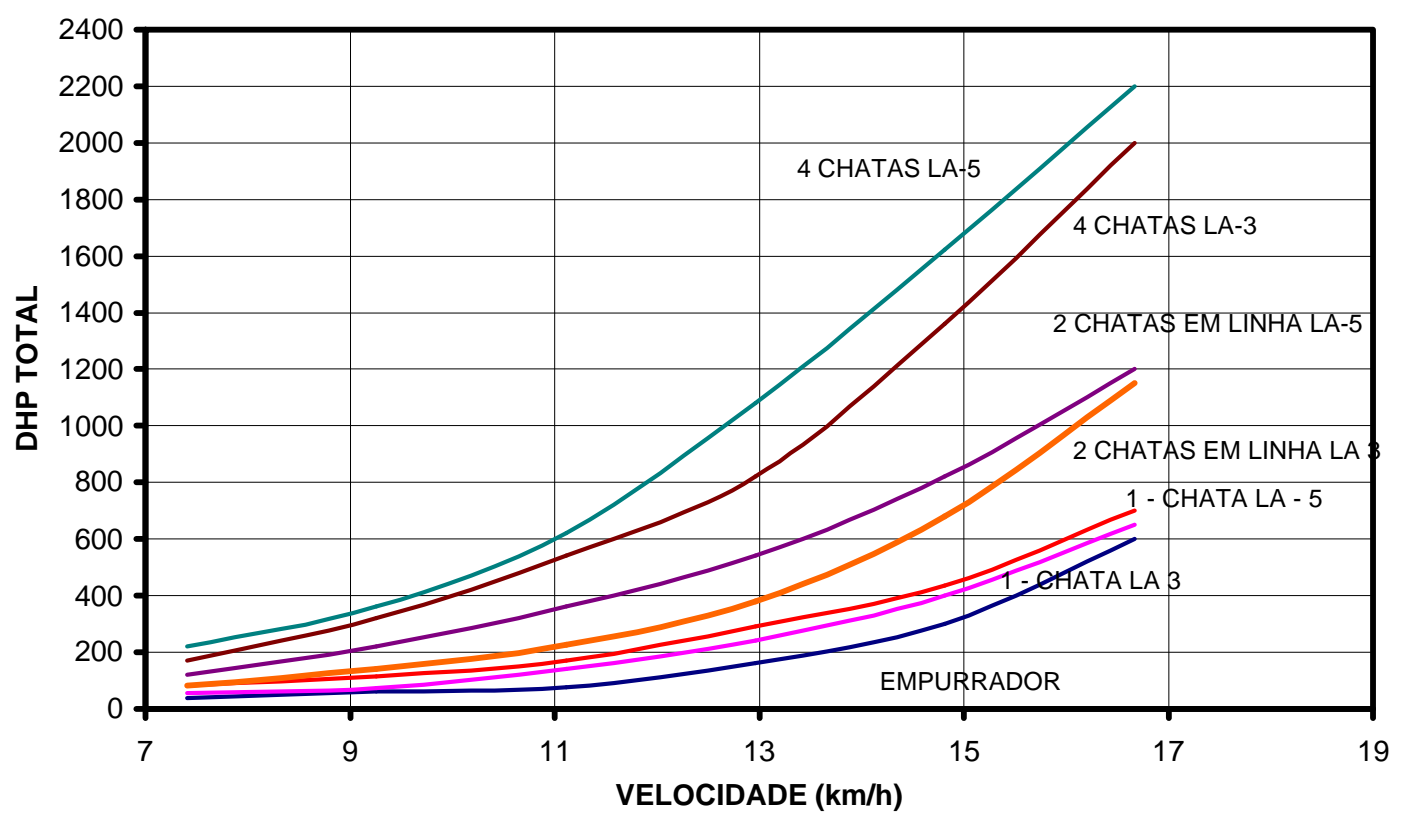

Figura B.2 - Potências obtidas em ensaios com modelo de comboio em escala reduzida (IPT, 1970). Chatas LA-3: calados de 1,5m; comprimento de $54,2 \mathrm{~m}$ e boca de $10,0 \mathrm{~m}$; Chatas LA-5: calados de 2,5m, comprimento $56,5 \mathrm{~m}$ e boca de $10,0 \mathrm{~m}$

\section{B.2 Dados relativos aos coeficientes propulsivos}

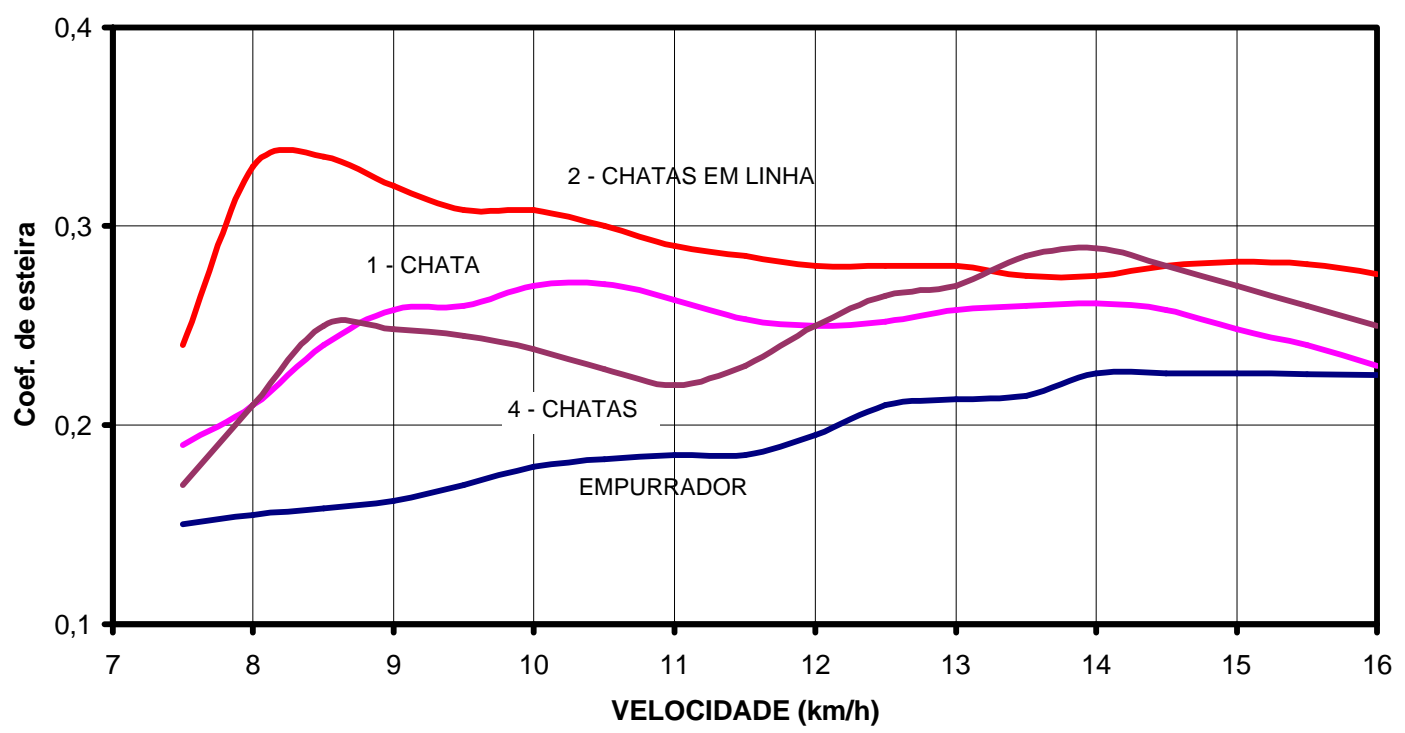

Figura B.3 - Coeficientes de esteiras obtidos com modelos de comboio em função da velocidade (IPT, 1970) 


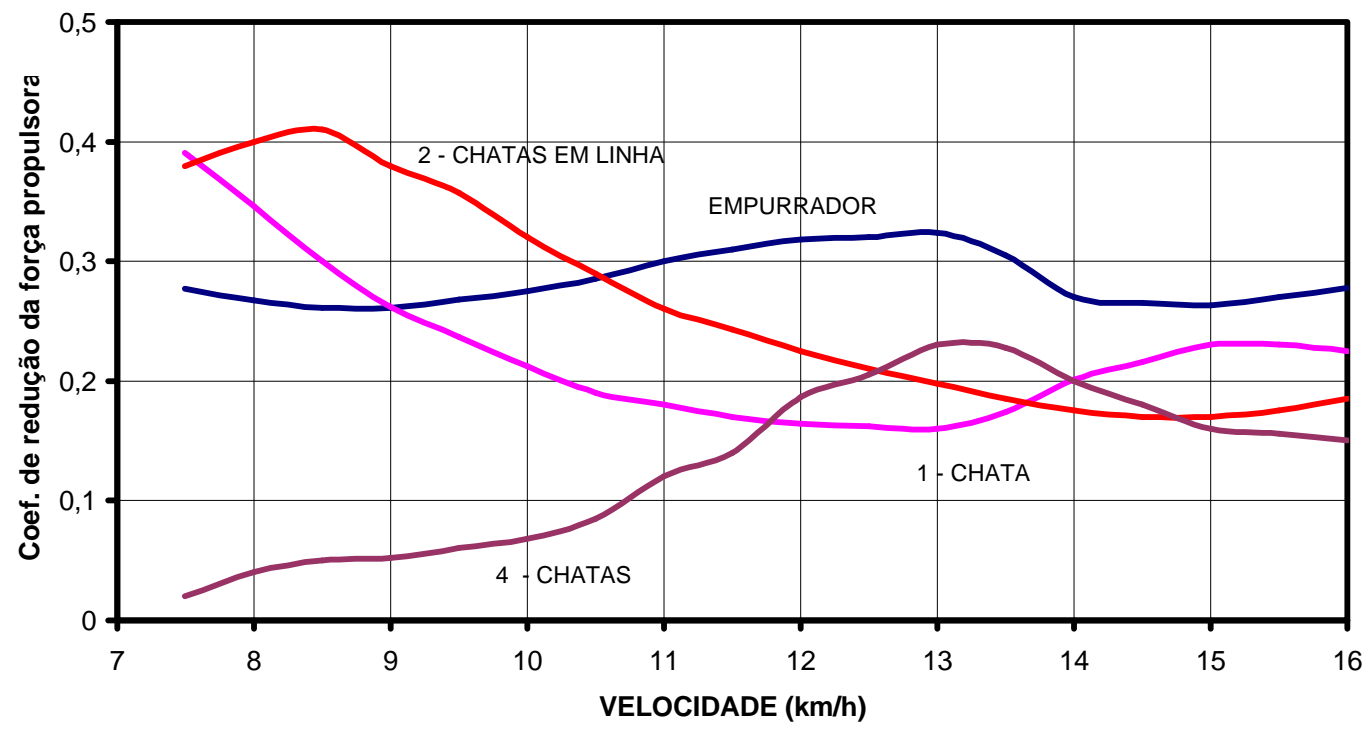

Figura B.4 - Coeficientes de redução da força propulsora obtidos com modelos de comboio em função da velocidade (IPT, 1970)

\section{coeficiente de esteira corrigido para escala real}

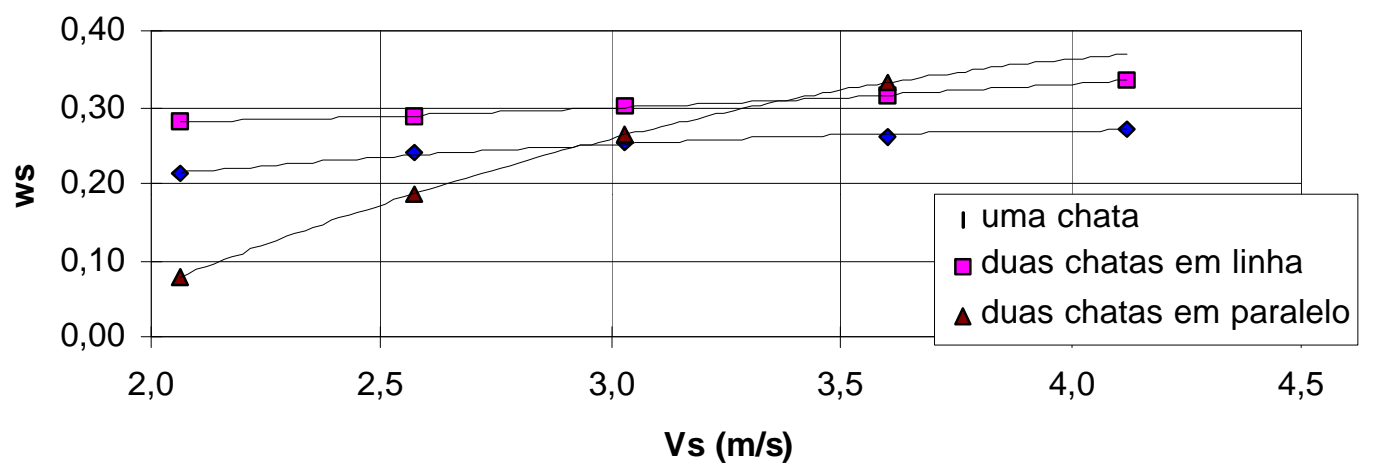

Figura B.5 - Coeficientes de esteiras obtidos para o comboio Araguaia, chatas carregadas (Padovezi, 1997) 


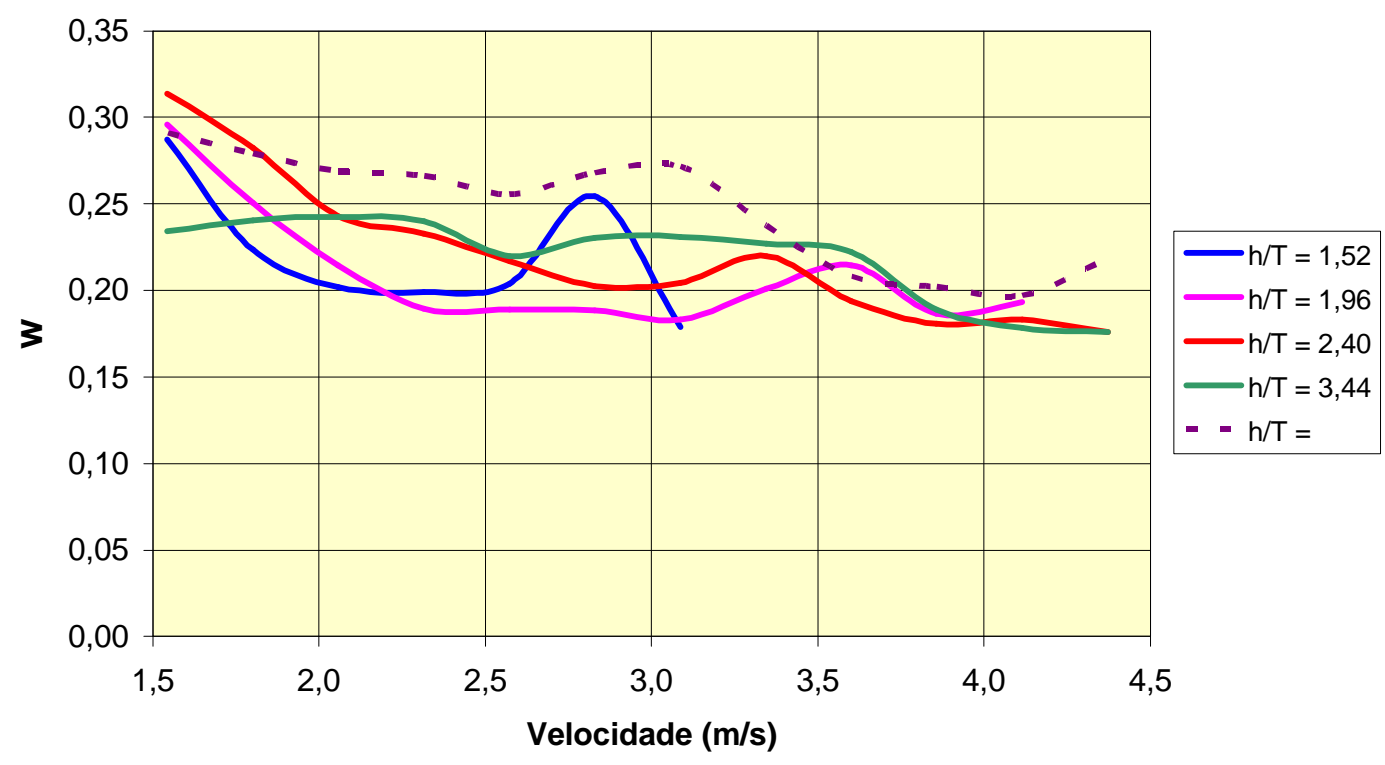

Figura B.6 - Coeficientes de esteiras obtidos com modelo de automotor, em função de h/T (IPT, 1973)

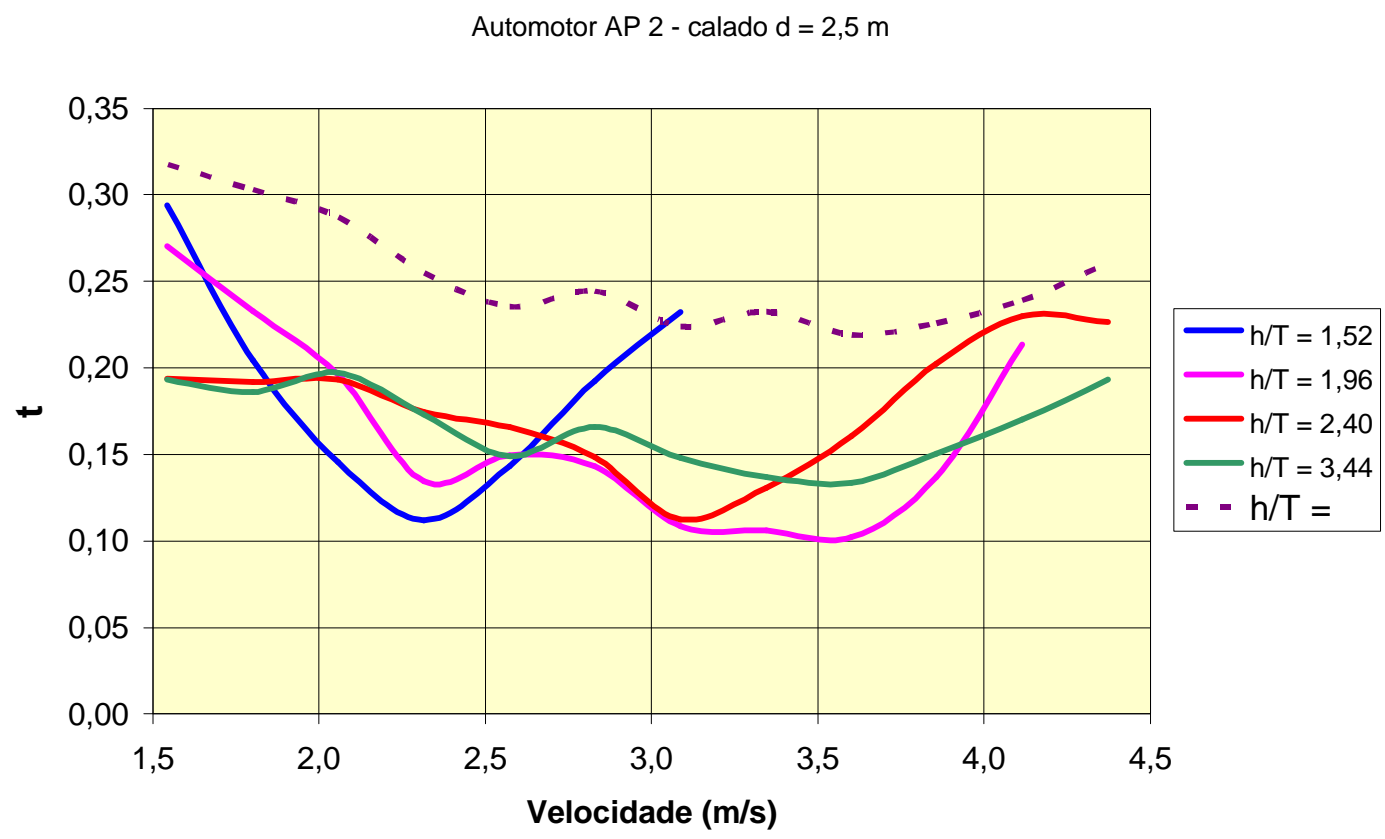

Figura B.7 - Coeficientes de redução de força propulsora obtidos com modelo de automotor, em função de h/T (IPT, 1973) 
Automotor AP 2 - calado $\mathrm{d}=2,5 \mathrm{~m}$

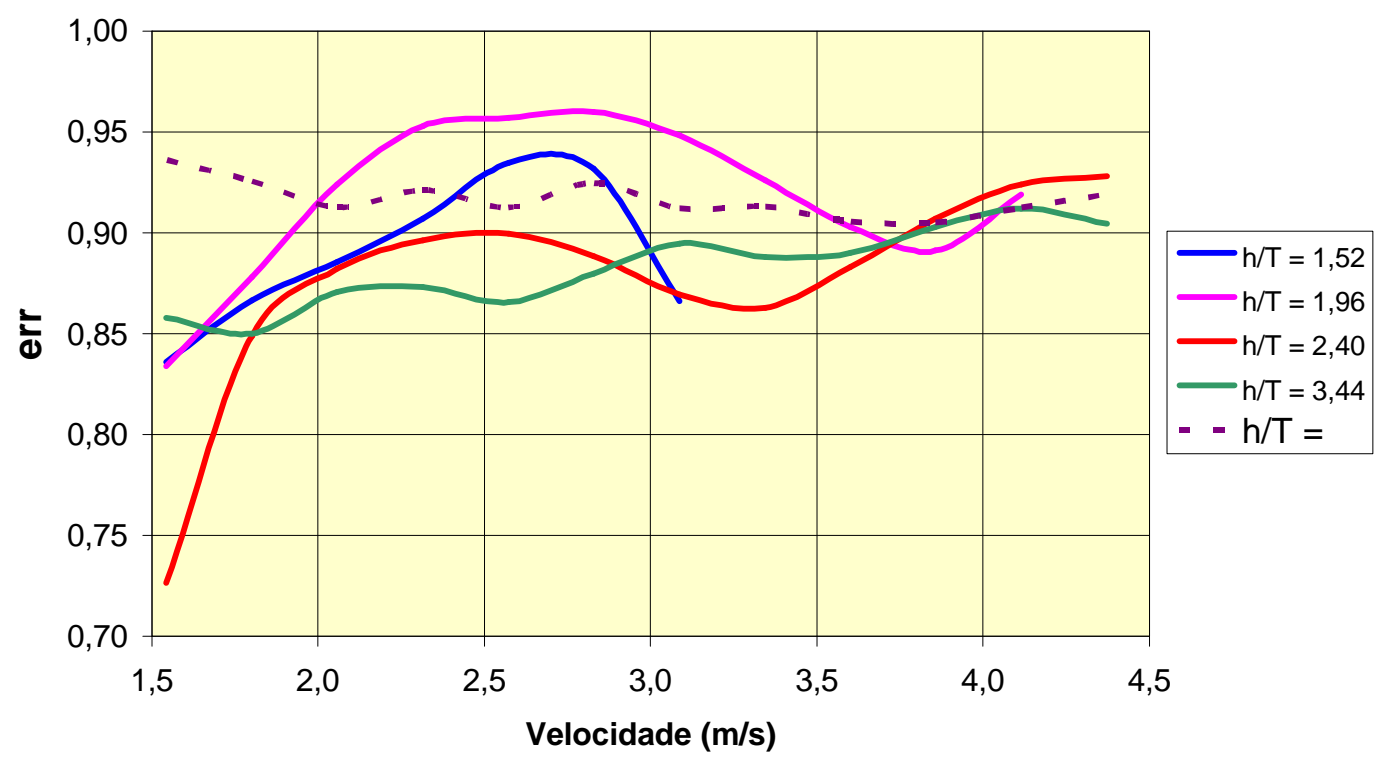

Figura B.8 - Coeficientes de eficiência relativa rotativa obtidos com modelo de automotor, em função de h/T (IPT, 1973)

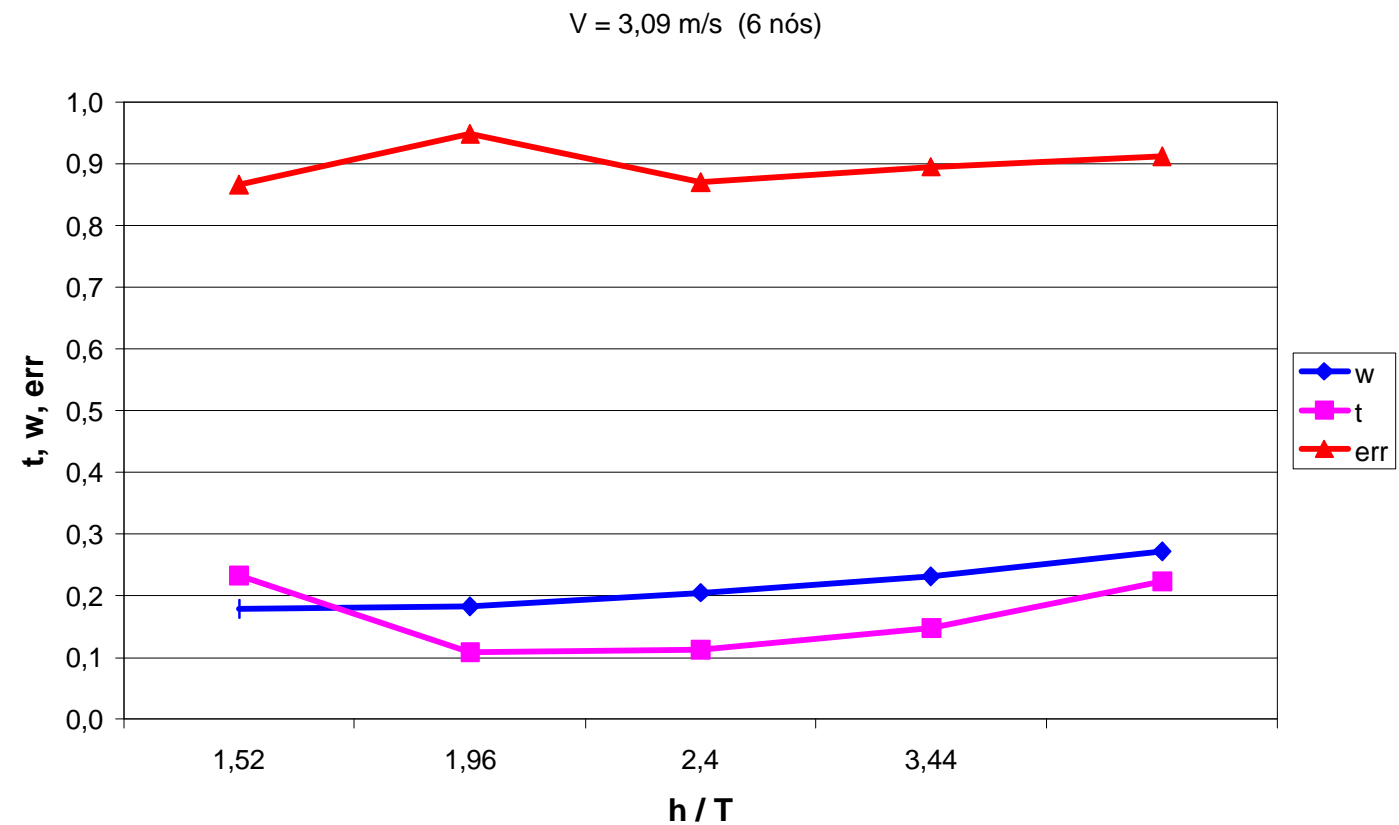

Figura B.9 - Variações de coeficientes propulsivos em função da profundidade, ensaios com modelo de automotor (IPT, 1973) 


\section{B.3 Dados relativos à manobras de comboios}

Tabela B.2 - Resultados de ensaios de giro com ângulo de leme de 35 graus e 811 rotações dos motores, modelo em escala $1: 6$ (Hirata, 2000)
comboio
calado (m) deslocamento(t)
$\mathbf{L}(\mathbf{m})$
$\operatorname{Dg}(\mathbf{m})$
$\mathbf{D g} / \mathbf{L}$

$\begin{array}{lrrrrr}1 \times 2 \text { carregado } & 0,417 & 15,0 & 23,0 & 66,5 & 2,89 \\ 1 \times 2 \text { leve } & 0,160 & 5,9 & 23,0 & 99,9 & 4,34 \\ 2 \times 2 \text { leve } & 0,160 & 11,3 & 23,0 & 114,2 & 4,97 \\ 2 \times 3 \text { leve } & 0,160 & 16,7 & 33,0 & 140,8 & 4,27\end{array}$

modelo escala $1: 6$

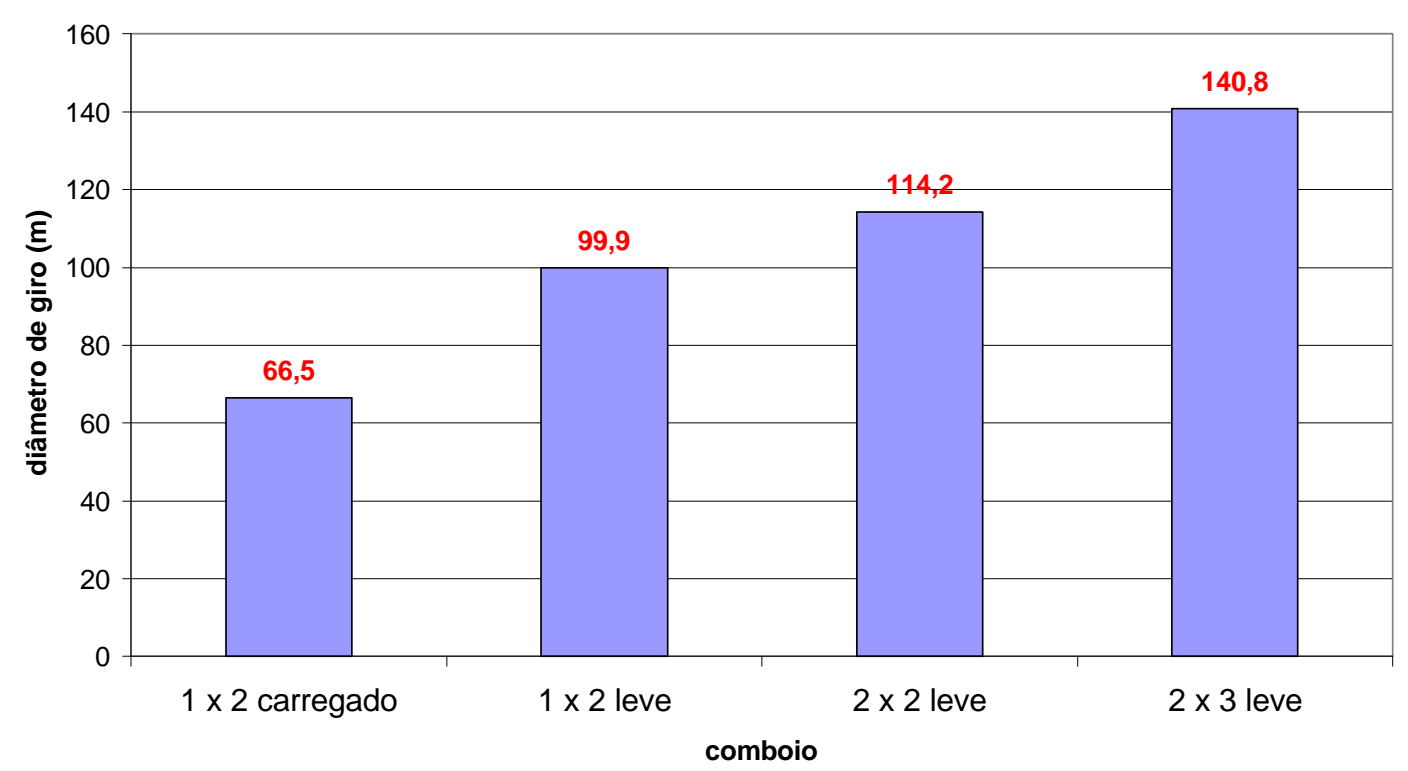

Figura B.10 - Resultados de ensaios de manobras de giro com comboio em escala 1:6 pilotado no rio Tietê. Diâmetros de giro em função da formação do comboio $(\mathrm{n}=811 \mathrm{rpm})$ 


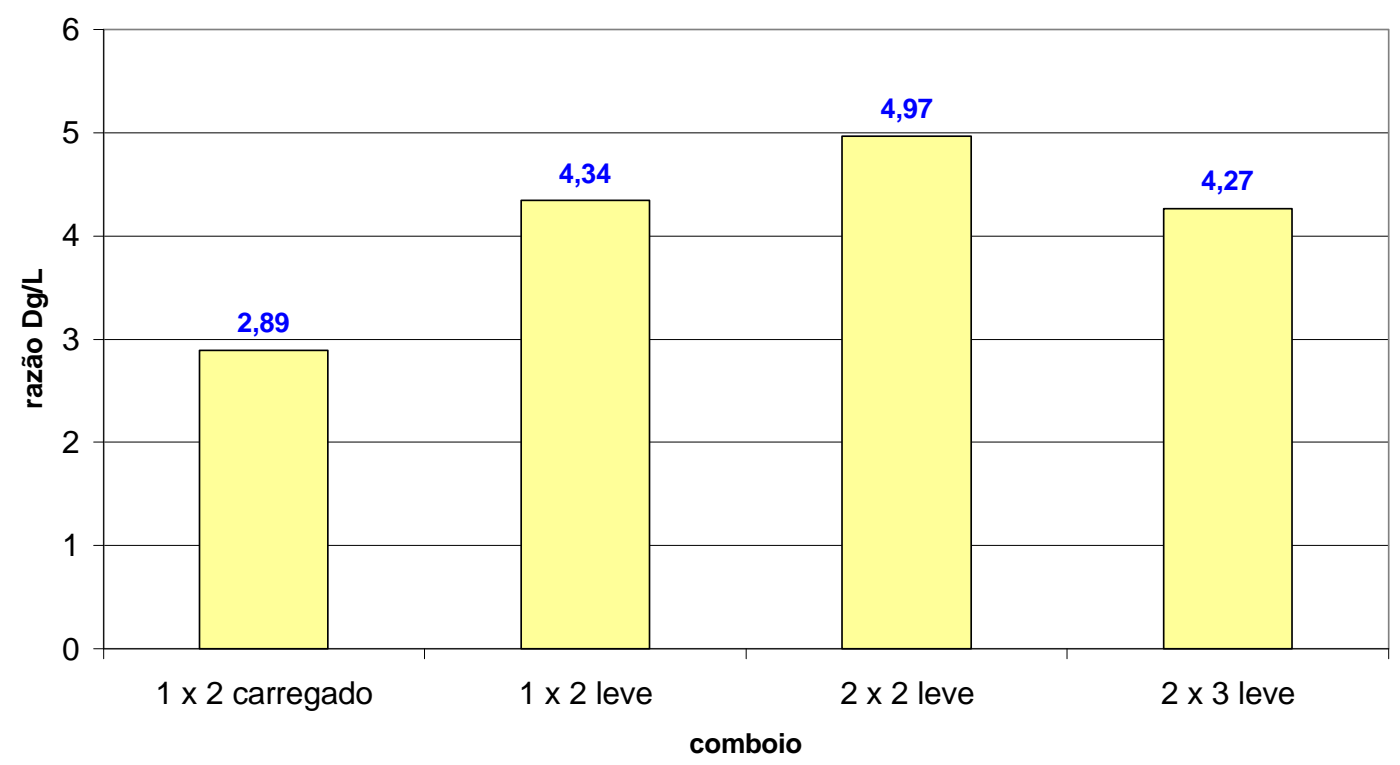

Figura B.11 - Resultados de ensaios de manobras de giro com comboio em escala 1:6 pilotado no rio Tietê. Razões diâmetros de giro pelo comprimento do comboio

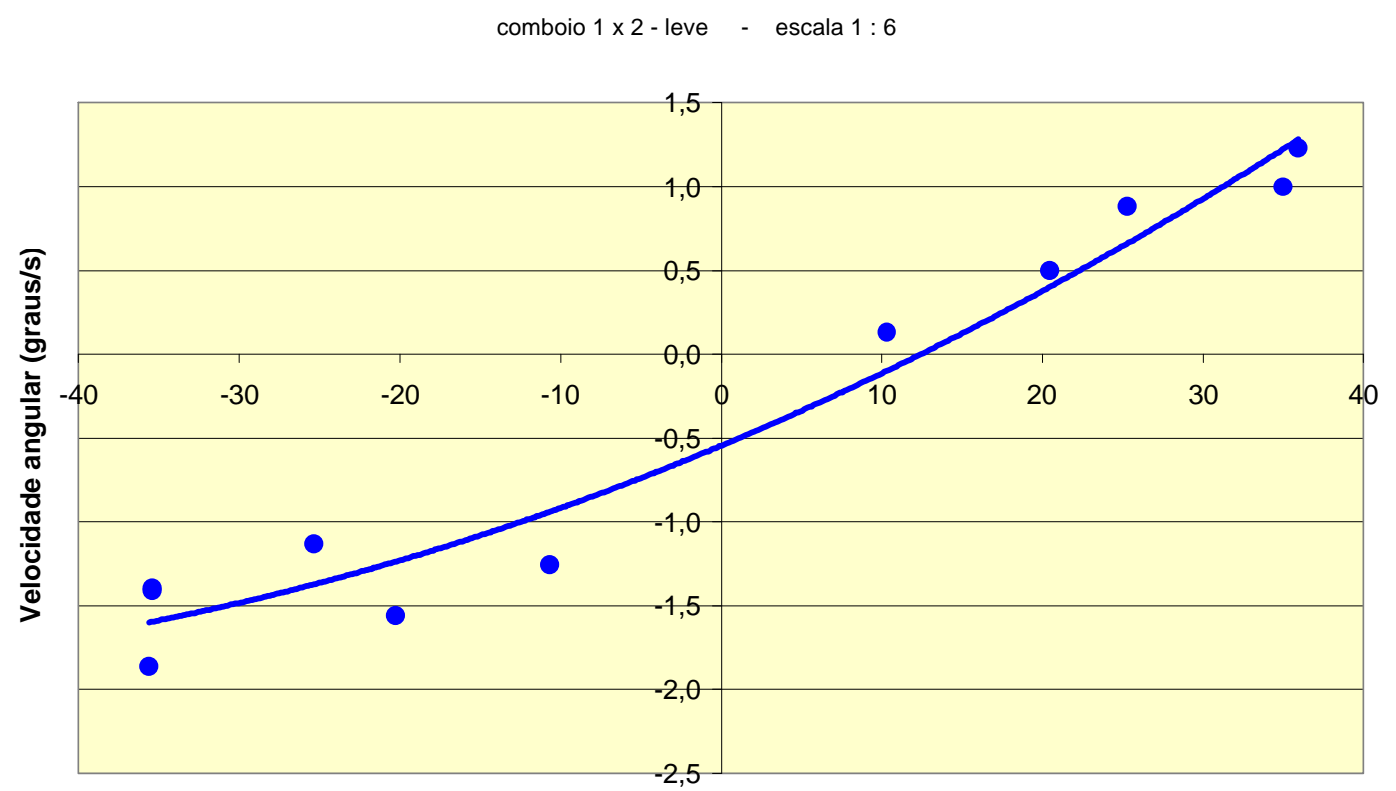

Angulo de leme (graus)

Figura B.12 - Resultados de ensaios de manobras com comboio em escala 1: 6 pilotado no rio Tietê. Velocidade angular em função do ângulo de leme 

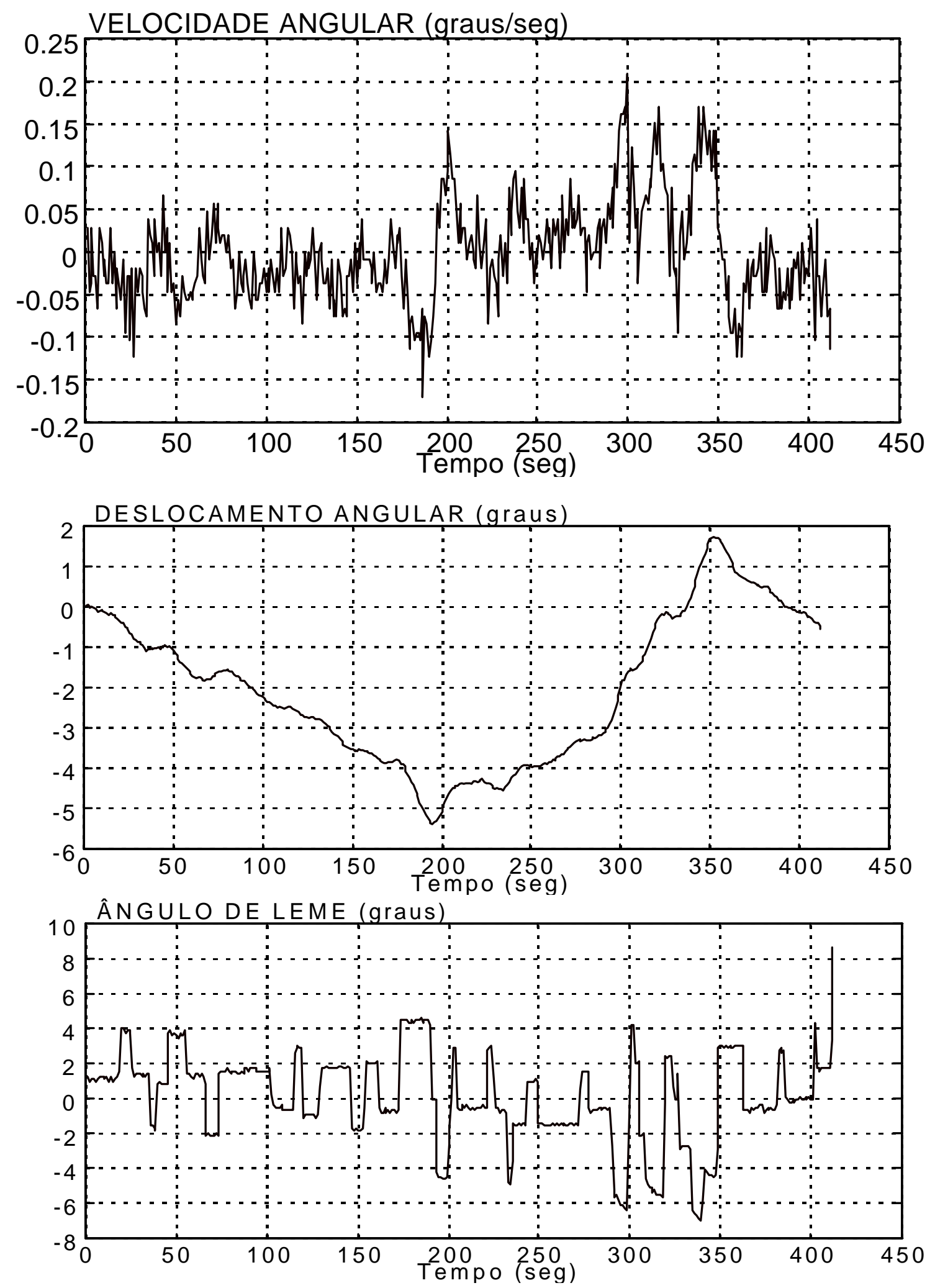

Figura B.13 - Ensaio de manutenção de rumo de comboio, em escala real, com duas chatas vazias em linha. Registros contínuos de velocidade angular, deslocamento e ângulo de lemes. Rio Tietê; ventos de intensidade moderada; sistema convencional de lemes e hélices 
Tabela B.3 - Comboio de duas chatas em linha, vazias, medidas de manobra em escala real, hidrovia Tietê-Paraná

\begin{tabular}{|l|c|}
\hline Área Lateral Exposta ao Vento & $717 \mathrm{~m}^{2}$ \\
\hline Diâmetro Tático (giro com lemes a 40 graus) & $514 \mathrm{~m}$ \\
\hline Velocidade Angular com Lemes a 20 graus & 0,43 graus/s \\
\hline $\begin{array}{l}\text { Variação Máxima de Ângulos para Manutenção do } \\
\text { Rumo do Comboio (sem ventos) }\end{array}$ & 6 graus \\
\hline
\end{tabular}


ANEXO C

DADOS DE ACIDENTES COM COMBOIOS 


\section{C.1 Diferenciação entre acidentes em trechos fáceis e em trechos difíceis e efeito do porte das embarcações}

(Brolsma et al., 1988) apresenta um levantamento de acidentes ocorridos no rio Reno, entre 1966 e 1985, em dois trechos diferenciados com relação à navegação:

- trecho considerado difícil, pela presença de curvas fechadas e largura restrita;

- trecho considerado fácil, com grande largura.

As Figuras C.1 e C. 2 e a Tabela C.1 mostram os resultados.

Há uma tendência de aumento do número de acidentes em função do aumento de porte das embarcações, assim como ocorre um maior número de acidentes no trecho de navegação difícil, comparados com os acidentes em trecho fácil.

Estas relações entre acidentes ocorridos serão utilizadas no modelo de risco, com base nas diferenças apresentadas na Figura C.2.

acidentes no Rio Reno - 1966 a 1985

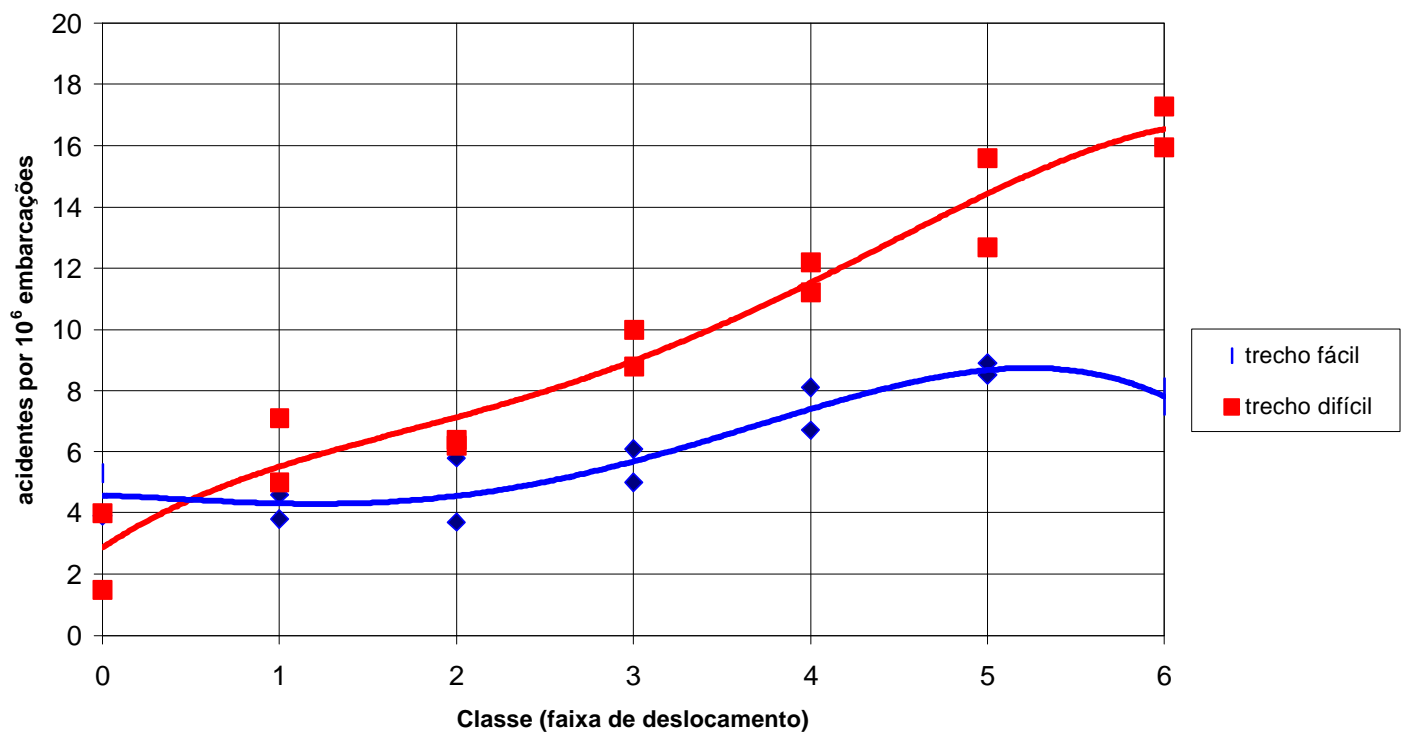

Figura C.1 - Número de acidentes de embarcações em trechos difíceis e em trechos fáceis no rio Reno, período de 1966 a 1985 (Brolsma et al., 1988). Classe de deslocamento definida na Tabela C.1 
Tabela C.1 - Classes de deslocamentos de embarcações e diferenças médias de acidentes em trechos difíceis e em trechos fáceis no rio Reno, período de 1966 a 1985 (Brolsma et al., 1988)

\begin{tabular}{|c|r|c|c|}
\hline \multirow{2}{*}{ classe } & \multirow{2}{*}{ deslocamento } & \multicolumn{2}{|c|}{ acréscimos $(\%)$} \\
\cline { 3 - 4 } & por dificuldade & por classe \\
\hline $\mathbf{0}$ & $50-200 \mathrm{t}$ & $-40,2$ & \\
\hline $\mathbf{1}$ & $201-450 \mathrm{t}$ & 44,0 & \\
\hline $\mathbf{2}$ & $451-750 \mathrm{t}$ & 32,6 & 0,0 \\
\hline $\mathbf{3}$ & $751-1.150 \mathrm{t}$ & 69,4 & 49,2 \\
\hline $\mathbf{4}$ & $1.151-1.550 \mathrm{t}$ & 58,1 & 85,7 \\
\hline $\mathbf{5}$ & $1.551-2.550 \mathrm{t}$ & 62,6 & 124,6 \\
\hline $\mathbf{6}$ & $2.551-5.000 \mathrm{t}$ & 113,1 & 163,9 \\
\hline
\end{tabular}

Sendo:

Acréscimo por dificuldade $=100 *$ [acidentes(trecho difícil $)$ - acidentes (trecho fácil) $] /$ acidentes(trecho fácil).

Acréscimo por classe $=100 *$ [acidentes (trecho difícil $)$ - acidentes (trecho difícil na classe 2)] / acidentes(trecho difícil na classe 2).

acidentes Rio Reno - 1966 a 1985

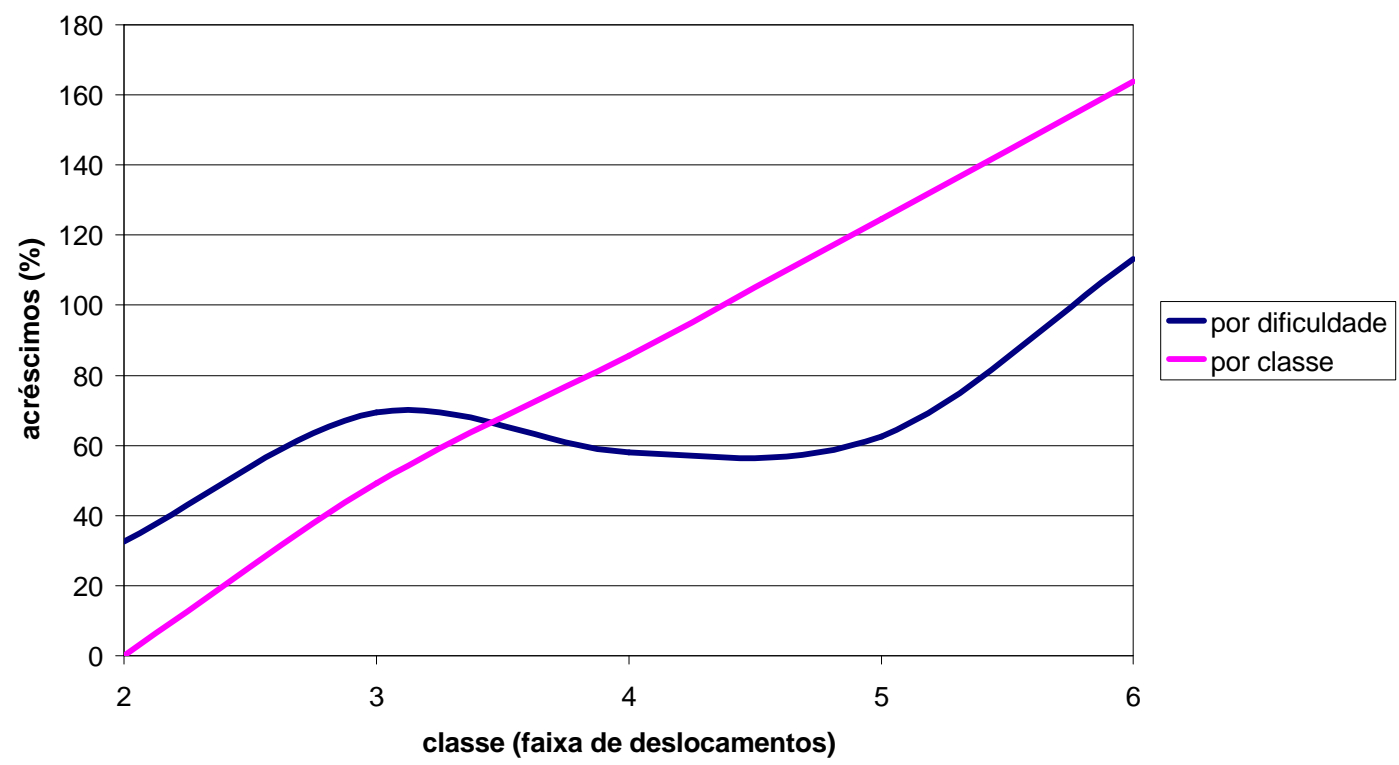

Figura C.2 - Acréscimos de acidentes por dificuldade de trechos e por classe de deslocamentos (no trecho difícil). Rio Reno, período de 1966 a 1985 (Brolsma et al., 1988) 
C.2 Base de dados de caidentes com comboios (Kite-Powell et al. 1998)

Tabela C.2 - Dados de acidentes com comboios (Kite-Powell et al., 1998), no período entre 1981 e 1995

\begin{tabular}{|l|c|c|c|c|}
\cline { 2 - 5 } \multicolumn{1}{c|}{} & New York & Tampa & Houston & $\begin{array}{c}\text { San } \\
\text { Francisco }\end{array}$ \\
\hline número de passagens (média anual) & 30.100 & 3.000 & 18.600 & 400 \\
\hline choques no fundo (1981 a 1995) & 73 & 81 & 327 & 13 \\
\hline colisões (1981 a 1995) & 305 & 68 & 376 & 45 \\
\hline choques no fundo por 1.000 passagens & 0,18 & 1,84 & 1,28 & 2,28 \\
\hline colisões por 1.000 passagens & 0,69 & 1,68 & 1,20 & 8,52 \\
\hline $\begin{array}{l}\text { acréscimos de choques no fundo com } \\
\text { visibilidade ruim }(*)\end{array}$ & $660 \%$ & $890 \%$ & $740 \%$ & $90 \%$ \\
\hline $\begin{array}{l}\text { acréscimos de colisões com visibilidade } \\
\text { ruim }(*)\end{array}$ & $630 \%$ & $810 \%$ & $600 \%$ & $160 \%$ \\
\hline
\end{tabular}

(*) - acréscimos percentuais de acidentes com visibilidade ruim $(<2 \mathrm{~km})$, comparados com acidentes com visibilidade boa $(>=2 \mathrm{~km})$

\section{C3. Acidentes em pontes}

A Tabela C.3 mostra 13 acidentes ocorridos em pontes na Hidrovia Tietê-Paraná. Alguns acidentes não se encontram na Tabela C.3 porque faltam dados considerados indispensáveis. No total, ocorreram 20 acidentes em pontes. A análise dos dados da Tabela 4 mostra que:

- cerca de $69 \%$ dos acidentes ocorreram com chatas vazias;

- cerca de $66 \%$ dos acidentes ocorreram à noite;

- em praticamente todos os acidentes, há relatos de más condições ambientais;

○ dois acidentes, com relato de correnteza forte, ocorreram no mês de janeiro, quando há grandes vazões devido às chuvas; os locais destes acidentes estão sujeitos a tais correntezas (a ponte da rodovia SP-147 fica à montante do 
último reservatório do rio Tietê e a ponte da rodovia BR-153 fica imediatamente à jusante da barragem de Promissão);

○ no início da navegação com comboios na hidrovia Tietê-Paraná, havia tráfego de comboios com quatro chatas sob pontes de vãos reduzidos.

Tabela C.3 - Colisões de comboios em pontes da hidrovia Tietê-Paraná

\begin{tabular}{|c|c|c|c|c|c|}
\hline Ponte & Vão (m) & Comboio & Calado & $\begin{array}{c}\text { Condições } \\
\text { ambientais }\end{array}$ & Data/hora \\
\hline SP-333 & 34,1 & $2 \times 2$ & Vazio & Vento forte & $\begin{array}{c}2 / 9 / 94 \\
1: 00 \mathrm{~h}\end{array}$ \\
\hline SP-425 & 31,3 & $2 \times 2$ & $\begin{array}{l}1 / 3 \mathrm{de} \\
\text { carga }\end{array}$ & Vento forte & $\begin{array}{l}15 / 9 / 94 \\
11: 45 \mathrm{~h}\end{array}$ \\
\hline BR-153 & 40,8 & $2 \times 2$ & Vazio & $\begin{array}{l}\text { Chuva, vento, } \\
\text { correnteza }\end{array}$ & $\begin{array}{l}4 / 11 / 94 \\
20: 30 \mathrm{~h}\end{array}$ \\
\hline BR-153 & 40,8 & $1 \times 2$ & Vazio & Correnteza forte & $\begin{array}{l}16 / 1 / 96 \\
15: 15 h\end{array}$ \\
\hline BR-153 & 40,8 & $1 \times 2$ & Vazio & $\begin{array}{l}\text { Vento e } \\
\text { correnteza }\end{array}$ & $\begin{array}{c}23 / 9 / 98 \\
14: 00 \mathrm{~h} \\
\end{array}$ \\
\hline SP-147 & 25,0 & $1 \times 3(*)$ & Carregado & Correnteza forte & $\begin{array}{l}14 / 1 / 95 \\
8: 20 \mathrm{~h}\end{array}$ \\
\hline SP-147 & 25,0 & $1 \times 3(*)$ & Carregado & & $\begin{array}{c}10 / 10 / 95 \\
19: 30 \mathrm{~h}\end{array}$ \\
\hline SP-463 & 35,0 & $1 \times 2$ & Carregado & & $\begin{array}{c}16 / 10 / 95 \\
\text { noite }\end{array}$ \\
\hline SP-463 & 62,3 & $1 \times 2$ & Vazio & Vento forte & $\begin{array}{l}4 / 4 / 99 \\
18: 00 \mathrm{~h}\end{array}$ \\
\hline SP-225 & 33,7 & $1 \times 2$ & Vazio & $\begin{array}{l}\text { Mudança de } \\
\text { direção de vento }\end{array}$ & $\begin{array}{c}23 / 4 / 99 \\
1: 30 \mathrm{~h}\end{array}$ \\
\hline SP-595 SJD & 35,0 & $1 \times 2$ & Vazio & $\begin{array}{l}\text { Vento forte / } \\
\text { mudança direção }\end{array}$ & $\begin{array}{l}7 / 4 / 97 \\
0: 00 \mathrm{~h}\end{array}$ \\
\hline SP-595 SJD & 35,0 & $1 \times 2$ & Vazio & & $10 / 9 / 99$ \\
\hline $\begin{array}{l}\text { Santa Fé do } \\
\text { Sul }\end{array}$ & 100,0 & $2 \times 2$ & Vazio & $\begin{array}{l}\text { Mudança de } \\
\text { direção de vento }\end{array}$ & $\begin{array}{c}22 / 3 / 98 \\
3: 40 \mathrm{~h}\end{array}$ \\
\hline
\end{tabular}

(*) chatas de comprimento entre 35 e 40 metros.

A Tabela C.4 apresenta, para as pontes onde ocorreram acidentes na hidrovia TietêParaná, as estimativas de probabilidade geométrica, PG, segundo critério da AASHTO (1991) adaptado no presente trabalho. Alguns vãos de pontes foram 
alterados ao longo do tempo (foram duplicados, pela eliminação do pilar central da ponte e utilização de tabuleiros metálicos).

Tabela C.4 - Acidentes em pontes da Hidrovia Tietê-Paraná

\begin{tabular}{|l|c|c|l|c|c|}
\hline Ponte & Comboio & Calado & \multicolumn{1}{|c|}{ Condições ambientais } & Vão (m) & PG \\
\hline SP-333 & $2 \times 2$ & Vazio & Vento forte & 34,1 & 0,426 \\
\hline SP-425 & $2 \times 2$ & $\begin{array}{c}\text { Meia } \\
\text { carga }\end{array}$ & Vento forte & 31,3 & 0,470 \\
\hline BR-153 & $2 \times 2$ & Vazio & Chuva, vento, correnteza & 40,8 & 0,380 \\
\hline BR-153 & $1 \times 2$ & Vazio & Correnteza forte & 40,8 & 0,208 \\
\hline BR-153 & $1 \times 2$ & Vazio & Vento e correnteza & 40,8 & 0,208 \\
\hline SP-463 & $1 \times 2$ & $\begin{array}{c}\text { Carregad } \\
\text { o }\end{array}$ & & 35,0 & 0,228 \\
\hline SP-463 & $2 \times 2$ & Vazio & Vento forte & 62,3 & 0,247 \\
\hline SP-225 & $1 \times 2$ & Vazio & $\begin{array}{l}\text { Mudança de direção de } \\
\text { vento }\end{array}$ & 33,7 & 0,232 \\
\hline SP-595 SJD & $1 \times 2$ & Vazio & $\begin{array}{l}\text { Vento forte / mudança } \\
\text { direção }\end{array}$ & 35,0 & 0,228 \\
\hline SP-595 SJD & $1 \times 2$ & Vazio & & 35,0 & 0,228 \\
\hline $\begin{array}{l}\text { Santa Fé do } \\
\text { Sul }\end{array}$ & $2 \times 2$ & Vazio & $\begin{array}{l}\text { Mudança de direção de } \\
\text { vento }\end{array}$ & 100,0 & 0,179 \\
\hline
\end{tabular}

As pontes passaram a contar com sistemas de proteção dos pilares junto às rotas de navegação e, assim, colisões leves, ou resvalos, que, anteriormente à existência de protetores colocavam em risco a integridade das pontes, têm sido absorvidas pelos sistemas de proteção. Ou seja, a partir de 1999, não há relatos de colisões com pilares de pontes também porque resvalos em sistemas de proteção não têm sido relatados como acidentes. Contudo, pode se afirmar que tais eventos são, no mínimo, incidentes que deveriam ser evitados.

A adoção de restrições de passagens de comboios sob pontes (em pontes sem sistemas de proteção de pilares, passava uma chata por vez) contribuiu para a diminuição dos acidentes. 
ANEXO D

DADOS DE ENTRADA DO PROGRAMA ADAPTA 
EXEMPLO DE APLICAÇÃO: HIDROVIA TIETÊ-PARANÁ

TRANSPORTE DE SOJA DE SÃO SIMÃO (GO) A PEDERNEIRAS (SP)

\subsubsection{Características da via}

Distância: 640 quilômetros

Número de trechos entre Pederneiras e São Simão: nTrecho = 17

Número de pontes entre Pederneiras e São Simão: nPontes $=9$

Número de eclusas existentes no trecho Pederneiras - São Simão: nEclusas = 5

Número de canais existentes no trecho Pederneiras - São Simão: nCanais = 3

Número de curvas fechadas entre Pederneiras e São Simão: nCurvas $=0$

Número de terminais entre Pederneiras e São Simão: nTerminal = 3

Tabela D.1 - Posição e detalhes dos 17 trechos a serem percorridos pelo comboio

\begin{tabular}{|c|c|c|c|c|c|c|}
\hline Trecho & km Início & km Final & $\begin{array}{c}\text { profun- } \\
\text { didade(m) }\end{array}$ & largura(m) & solo & $\begin{array}{c}\text { corrente } \\
(\mathbf{m} / \mathbf{s})\end{array}$ \\
\hline 1 & 0,0 & 6,1 & 7,0 & 830 & rocha & $+0,3$ \\
\hline 2 & 6,1 & 21,8 & 13,7 & 970 & lodos & $+0,3$ \\
\hline 3 & 21,8 & 26,8 & 18,5 & 1.040 & lodos & $+0,2$ \\
\hline 4 & 26,9 & 36,6 & 4,1 & 220 & rocha & $+0,5$ \\
\hline 5 & 36,6 & 75,3 & 8,9 & 850 & rocha & $+0,3$ \\
\hline 6 & 75,3 & 99,3 & 14,8 & 1.220 & lodos & $+0,3$ \\
\hline 7 & 99,5 & 113,5 & 6,0 & 890 & rocha & $+0,5$ \\
\hline 8 & 113,5 & 136,5 & 10,7 & 1.880 & lodos & $+0,3$ \\
\hline 9 & 136,5 & 203,5 & 18,2 & 4.030 & lodos & $+0,2$ \\
\hline 10 & 203,6 & 220,6 & 5,0 & 1.440 & rocha & $+0,5$ \\
\hline 11 & 220,6 & 252,2 & 19,8 & 2.840 & lodos & $+0,2$ \\
\hline 12 & 253,5 & 288,5 & 7,4 & 1.080 & rocha & $+0,5$ \\
\hline 13 & 288,5 & 368,9 & 26,8 & 3.750 & lodos & $+0,2$ \\
\hline 14 & 368,9 & 382,9 & 12,5 & 540 & lodos & $+0,2$ \\
\hline 15 & 382,9 & 418,9 & 16,8 & 1.120 & lodos & $+0,2$ \\
\hline 16 & 418,9 & 669,0 & 15,0 & 2.200 & lodos & $-0,3$ \\
\hline 17 & 469,0 & 640,0 & 10,0 & 800 & lodos & $-0,3$ \\
\hline
\end{tabular}


Observações:

a) na Tabela 1: km $0=$ Pederneiras e $\mathrm{km} 640=$ São Simão;

b) os sinais das velocidades de correntes são determinados com relação ao trajeto da viagem de ida, sendo positivo para embarcação descendo o rio e negativo para embarcação subindo o rio; no caso do exemplo, a ida é pelo rio Tietê (descendo) e pelo Paraná (subindo).

Tabela D.2 - Pontes existentes entre Pederneiras e São Simão

\begin{tabular}{|c|c|c|c|c|c|c|}
\hline \multirow[t]{2}{*}{ PONTE } & \multirow[t]{2}{*}{$\begin{array}{c}\text { vaoPonte } \\
\text { (m) }\end{array}$} & \multirow[t]{2}{*}{$\begin{array}{l}\text { profPonte } \\
\text { (m) }\end{array}$} & \multirow[t]{2}{*}{$\begin{array}{l}\text { largPonte } \\
\text { (m) }\end{array}$} & \multirow[t]{2}{*}{$\begin{array}{l}\text { largPilar } \\
(\mathbf{m})\end{array}$} & \multicolumn{2}{|c|}{$\begin{array}{l}\text { velocCorrente } \\
(\mathrm{m} / \mathrm{s})\end{array}$} \\
\hline & & & & & Paral. & Perp. \\
\hline SP-225 & 33,0 & 10 & 500 & 1,4 & 0,3 & 0 \\
\hline SP-333 & 34,0 & 25 & 1.250 & 1,0 & 0,3 & 0 \\
\hline SP-425 & 31,0 & 18 & 1.140 & 2,2 & 0,3 & 0 \\
\hline BR-153 & 40,0 & 5 & 50 & 3,0 & 0,3 & 0 \\
\hline SP-461 & 77,0 & 5 & 420 & 2,2 & 0,3 & 0,2 \\
\hline SP-463 & 55,0 & 15 & 1.140 & 3,0 & 0,3 & 0 \\
\hline Jacaré & 81,0 & 29 & 1.860 & 2,2 & 0,3 & 0 \\
\hline SP-595 SJD & 68,0 & 23 & 990 & 2,0 & 0,3 & 0 \\
\hline Sta. Fé Sul & 100,0 & 15 & 1.000 & 15,0 & $-0,3$ & 0 \\
\hline
\end{tabular}

\section{descrição}

Vão horizontal da ponte, por onde passa o canal de navegação (m)

Profundidade média no local da ponte $(\mathrm{m})$

Largura media no local da ponte $(\mathrm{m})$

Largura dos pilares junto ao vão de navegação $(\mathrm{m})$

Condições ambientais no local da ponte: $1=$ =boas; $2=$ regulares e $3=$ ruins

símbolo

vaoPonte profPonte largPonte largPilar ambientePonte

Tabela D.3 - Eclusas existentes entre Pederneiras e São Simão

\begin{tabular}{|l|c|c|c|c|c|}
\hline \multicolumn{1}{|c|}{ Eclusa } & $\begin{array}{c}\text { compEclusa } \\
(\mathbf{m})\end{array}$ & $\begin{array}{c}\text { calEclusa } \\
(\mathbf{m})\end{array}$ & $\begin{array}{c}\text { largEclusa } \\
(\mathbf{m})\end{array}$ & $\begin{array}{c}\text { atendEclusa } \\
(\mathbf{h})\end{array}$ & $\begin{array}{c}\text { desvEclusa } \\
(\mathbf{h})\end{array}$ \\
\hline Bariri & 139,5 & 3,0 & 11,0 & 1,0 & 0,2 \\
\hline Ibitinga & 139,5 & 3,0 & 11,0 & 1,0 & 0,2 \\
\hline Promissão & 139,5 & 3,0 & 11,0 & 1,0 & 0,2 \\
\hline Nova Avanhandava sup. & 139,5 & 3,0 & 11,0 & 1,0 & 0,2 \\
\hline Nova Avanhandava inf. & 139,5 & 3,0 & 11,0 & 1,0 & 0,2 \\
\hline
\end{tabular}

\section{descrição}

Comprimento máximo de uma embarcação na eclusa (m)

Calado máximo de uma embarcação na eclusa (m)

Largura máxima de uma embarcação na eclusa (m)

\section{símbolo}

compEclusa profEclusa largEclusa 
Tempo médio de atendimento na eclusa (h)

Desvio padrão do tempo de atendimento (h)
atendEclusa

desvEclusa

Tabela D.4 - Canais existentes entre Pederneiras e São Simão

\begin{tabular}{|l|c|c|c|c|c|}
\hline \multicolumn{1}{|c|}{ Canal } & $\begin{array}{c}\text { extCanal } \\
(\mathbf{k m})\end{array}$ & $\begin{array}{c}\text { profCanal } \\
(\mathbf{m})\end{array}$ & $\begin{array}{c}\text { largCanal } \\
(\mathbf{m})\end{array}$ & $\begin{array}{c}\text { atendCanal } \\
(\mathbf{h})\end{array}$ & $\begin{array}{c}\text { desvCanal } \\
(\mathbf{h})\end{array}$ \\
\hline Bariri & 4,6 & 6,0 & 70,0 & 0,6 & 0,2 \\
\hline Promissão & 1,2 & 5,5 & 50,0 & 0,3 & 0,2 \\
\hline Pereira Barreto & 9,6 & 9,0 & 70,0 & 1,0 & 0,2 \\
\hline
\end{tabular}

\section{descrição}

Extensão do canal (m)

Profundidade do canal (m)

Largura do canal (m)

Tempo médio de atendimento na passagem no canal (h)

Desvio padrão do tempo de atendimento (h)

\section{símbolo}

extCanal

profCanal

largCanal

atendCanal

desvCanal

Tabela D.5 - Terminais utilizados entre Pederneiras e São Simão

\begin{tabular}{|l|c|c|c|c|}
\hline \multicolumn{1}{|c|}{ Terminal } & $\begin{array}{c}\text { posTerminal } \\
(\mathbf{k m})\end{array}$ & $\begin{array}{c}\text { txcarga } \\
\mathbf{( t / h )}\end{array}$ & $\begin{array}{c}\text { txdescarga } \\
(\mathbf{t} / \mathbf{h})\end{array}$ & $\begin{array}{c}\text { calado } \\
(\mathbf{m})\end{array}$ \\
\hline Pederneiras & 0 & 0 & 100 & 0,5 \\
\hline São Simão & 640 & 120 & 0 & 2,7 \\
\hline Pederneiras & 0 & 0 & 100 & 0,5 \\
\hline
\end{tabular}

\section{descrição}

Posição do terminal $(\mathrm{km})$

Taxa de carga do terminal $(\mathrm{t} / \mathrm{h})$

Taxa de descarga do terminal $(\mathrm{t} / \mathrm{h})$

Calado das chatas na saída do terminal (m) símbolo

posTerminal

Txcarga

txdescarga

calado

\subsubsection{Características do comboio}

\section{Empurrador}

\section{descrição}

Comprimento total

Boca moldada

Pontal

Calado de operação

Coeficiente de bloco

$\begin{array}{ll}\text { símbolo } & \text { valor } \\ \text { Lemp } & 19,50 \mathrm{~m} \\ \text { Bemp } & 8,23 \mathrm{~m} \\ \text { Pemp } & 2,90 \mathrm{~m} \\ \text { Temp } & 2,40 \mathrm{~m} \\ \text { CB_emp } & 0,636\end{array}$




\section{Motores}

\section{descrição}

Quantidade de motores / hélices

$\begin{array}{ll}\text { símbolo } & \text { valor } \\ \text { numMot } & 2 \\ \text { MCR } & 330 \mathrm{~kW} \\ \text { rotNom } & 1.800 \mathrm{rpm} \\ \text { margem } & 0,85 \\ \text { efic_transm } & 0,95\end{array}$

Caixas Redutoras / Reversoras

descrição

$\begin{array}{ll}\text { símbolo } & \text { valor } \\ \text { reducao } & 6,458: 1\end{array}$

Relação de redução de rotações

$$
\text { reducao } \quad 6,458: 1
$$

\section{Hélices}

\section{descrição}

Tipo de propulsor

Série sistemática

Diâmetro

Número de pás

Razão passo / diâmetro

Razão de área expandida

\section{Lemes}

descrição

Quantidade de lemes principais

Tipo dos lemes principais

Área de um leme

Existem lemes de flancos?

Existem lemes de proa?

Existem impelidores laterais de proa?

$\begin{array}{ll}\text { símbolo } & \text { valor } \\ \text { Prop_tipo } & 1=\text { aberto } \\ \text { serie } & \text { Troost (B) } \\ \text { rotNom } & 1,70 \mathrm{~m} \\ \text { nPas } & 4 \\ \text { P_D } & 0,77 \\ \text { AeAo } & 0,70\end{array}$

$\begin{array}{ll}\text { símbolo } & \text { valor } \\ \text { nLeme } & 2 \\ \text { tipo_leme } & 1=\text { convencional } \\ \text { area_leme } & 2,70 \mathrm{~m}^{2} \\ \text { flancos } & \text { sim } \\ \text { lemes_proa } & \text { nao } \\ \text { bow_thruster } & \text { nao }\end{array}$

$\begin{array}{ll}\text { símbolo } & \text { valor } \\ \text { Lchata } & 59,44 \mathrm{~m} \\ \text { Bchata } & 10,67 \mathrm{~m} \\ \text { Pchata } & 3,66 \mathrm{~m} \\ \text { Tmax } & 3,00 \mathrm{~m} \\ \text { Cbchata } & 0,915\end{array}$

Formação do Comboio

descrição

Número de linhas de chatas

Número de colunas de chatas

Características de Cada Chata descrição

Comprimento total

Boca moldada

Pontal

Calado máximo

Coeficiente de bloco
Cbchata

$\begin{array}{ll}\text { símbolo } & \text { valor } \\ \text { nLinhas } & 2 \\ \text { nColunas } & 2\end{array}$




\subsubsection{Dados operacionais}

\section{descrição}

Número de tripulantes

Salário médio dos tripulantes

Valor do rancho diário por tripulante

Índice de disponibilidade da via

Fração de tempo de espera de carga ou

descarga (se há chatas prontas...)

Custo de embarque / desembarque

Número de dias por ano utilizados em

manutenção do comboio

Fluxo médio de chegada de embarcações

em eclusas e canais, nos dois sentidos

Custo do litro de óleo Diesel

$\begin{array}{ll}\text { símbolo } & \text { valor } \\ \text { Ntrip } & 7 \\ \text { Salário_medio } & 600 \text { reais } \\ \text { rancho_dia } & \begin{array}{l}7 \text { reais } \\ 85 \%\end{array} \\ \text { IDV } & \\ \text { espera_carga } & 0,2 \\ \text { custo_t_term } & \mathrm{R} \$ 1,00 \text { por tonelada } \\ \text { NDM } & 10 \text { dias/ano } \\ \text { lambt } & 0,2 \text { comboio/hora } \\ \text { CuOD } & 1,2 \text { real / litro }\end{array}$


ANEXO E

LISTAGEM DO PROGRAMA ADAPTA 
Listagem do Programa ADAPTA, em disquete em anexo. 


\section{ADAPTA}

function adapta

$\%$ Esta funçao funciona como o programa principal ADAPTA que tem por

$\%$ objetivo avaliar o quao adaptado eh um determinado comboio em uma dada

$\%$ hidrovia. Assim, com as caracteristicas detalhadas do comboio e da hidrovia

$\%$ eh realizada uma avaliaçao da eficiencia, da segurança e da interferencia

$\%$ ambiental da navegaçao.

$\%$ entradas:

$\%$ funçao ENTRA

$\%$

\% saidas:

\% funçoes RELATO, COMPARA e RECOMENDA

$\%$

$\%$ funçoes principais de calculos e analises:

$\%$ PROPULSAO, MANOBRAS, RISCOS, CUSTOS, AMBIENTE, RASO, CURVAS, ESTREITO,

$\%$ ECLUSAS_CANAIS, TRONCOS, VENTOS, NEBLINA, CORRENTE, ONDAS, PONTES, IDEAL

$\%$

$\%$ sub-funçoes (ou funçoes auxiliares)

$\%$ HOWE, BTROOST, KAPLAN, COEFPROP, QUEDAEMPUXO, PROBABILIDADES

$\%$

global nTrecho nTerminal posTrecho posTerminal calado profundidade ... largura corrente solo nPontes nCurvas nivelVentos nivelOndas ... nivelTroncos nivelNeblina nEclusas nCanais txcarga txdescarga global Lchata Bchata Pchata Tmax nLinhas nColunas nMotor MCR RotNom ... reducao prop_tipo serie diametro AeAo nPas P_D nLemes tipo_Leme ... area_Leme flancos Lemp Bemp Temp Pemp CB_emp CBchata lemes_proa ... 
bow_thruster KaDuto tempo_passagem_pontes Cterminais global raioCurva largCurva profCurva corrCurva vaoPonte largPilar ... largPonte profPonte ambientePonte extCanal largCanal profCanal ... atendCanal desvCanal largEclusa compEclusa calEclusa ... atendEclusa desvEclusa cal Dt Wt ht Vct posMax Imax global rpmMotor PBt Vreal Vt PA Rt empuxo_Vo deslocamento B Porc_Duto global Ctotal Custo_tonelada fator_merito Custo_tonelada_km risco_ponte global Ctotal_id Custo_tonelada_id fator_merito_id Custo_tonelada_km_id $\%$ Entrada de Dados:

entra

[posMax,Imax]=max(posTerminal);

$\mathrm{Dt}=\operatorname{zeros}(1,2 *$ nTrecho $)$;

trechoInic $=$ zeros $(1$, nTrecho $)$;

trechoInic $=[0$ posTrecho $(1:($ nTrecho- 1$))]$;

AAA $=$ posTrecho-trechoInic;

$\mathrm{BBB}=$ fliplr(AAA);

$\mathrm{Dt}=[\mathrm{AAA} \mathrm{BBB}]$;

for $\mathrm{i}=1$ : nTrecho

$\operatorname{cal}(\mathrm{i})=\operatorname{calado}(1)$

$\operatorname{solo}(2 *$ nTrecho+1-i $)=\operatorname{solo}(i)$;

$\operatorname{cal}(2 *$ nTrecho+1-i $)=\operatorname{calado}($ nTerminal -1$) ;$

$\mathrm{Wt}(\mathrm{i})=\operatorname{largura}(\mathrm{i})$;

$\operatorname{Vct}(i)=$ corrente $(i)$;

ht $(\mathrm{i})=$ profundidade $(\mathrm{i})$;

$\mathrm{Wt}(2 *$ nTrecho+1-i) $=\mathrm{Wt}(\mathrm{i})$;

$\operatorname{Vct}(2 *$ nTrecho+1-i $)=-1 * \operatorname{Vct}(\mathrm{i}) ; \%$ inversao do sinal da corrente

$\operatorname{ht}(2 *$ nTrecho+1-i $)=h t(i)$;

end

compr_comboio=Lemp + nColunas $*$ Lchata; 


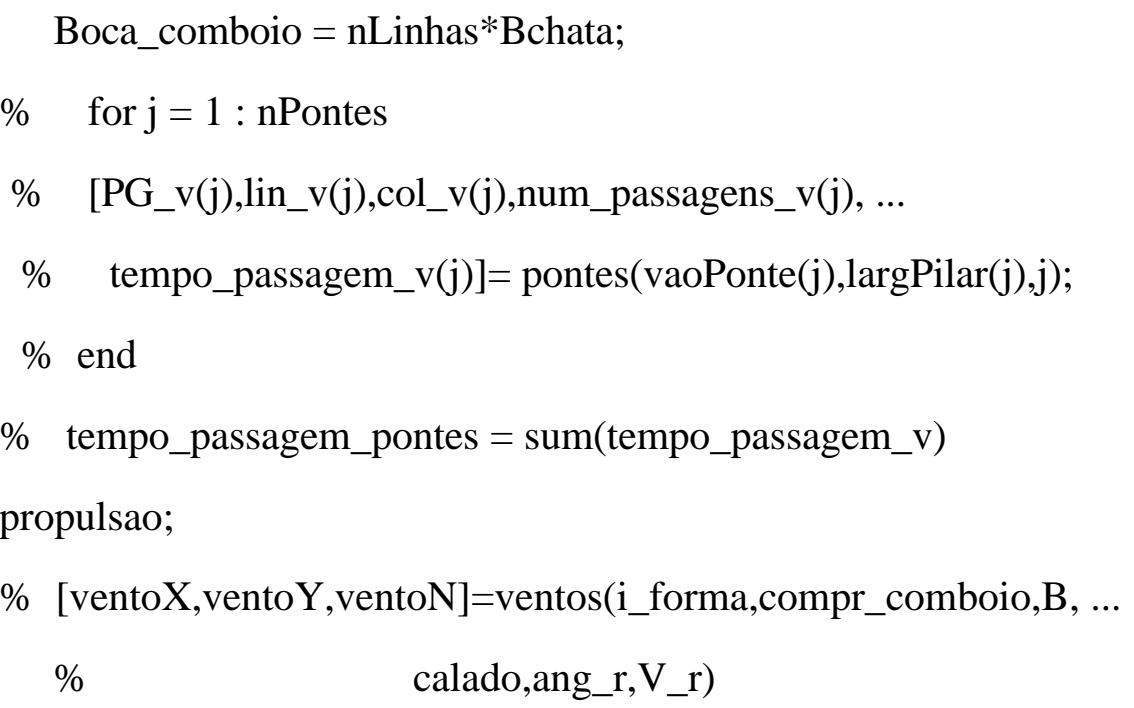

[Ctotal,Custo_tonelada,fator_merito,Custo_tonelada_km,NVc] ...

$$
=\text { custos }
$$

$\% \mathrm{NPano}=\mathrm{NVc} \cdot *$ num_passagens_v;

$\%$ freq_acid_ponte $=$ NPano. $*$ risco_ponte;

for $\mathrm{ij}=1: 2 *$ nTrecho

if ht(ij) $-\operatorname{cal}(\mathrm{ij})<=1.2$

[Squat(ij),piloto(ij),Vcorrig(ij)]=raso(Boca_comboio,cal(ij),ht(ij), ...

Wt(ij),Vt(ij),solo(ij),2)

end

end

aux_calc $=$ ht./cal;

distancia_parada=paradabrusca $(\mathrm{Rt}, \mathrm{Vt}$,deslocamento,empuxo_Vo,... aux_calc,nMotor,nTrecho);

distParada_L = distancia_parada./compr_comboio

$$
\text { trechos }=\text { linspace }(1,2 * \text { nTrecho, } 2 * \text { nTrecho }) \text {; }
$$

aaa $=[$ trechos' Vreal' Vt' rpmMotor' PBt' $]$

save ('relato.mat','aaa');

figure;

plot(rpmMotor(1:nTrecho),Vt(1:nTrecho),'rp',... 
rpmMotor(nTrecho+1:2*nTrecho),Vt(nTrecho+1:2*nTrecho),'bp');

title('V x rpm ao longo da viagem')

set( $(0$, 'DefaultAxesXgrid','on')

set(0,'DefaultAxesYgrid','on')

Xlabel('rotaçoes motores (rpm)')

Ylabel('V (m/s)')

figure;

plot(rpmMotor(1:nTrecho),PBt(1:nTrecho),'rp',...

rpmMotor(nTrecho+1:2*nTrecho),PBt(nTrecho+1:2*nTrecho),'bp');

title('PB x rpm ao longo da viagem')

$\operatorname{set}(0$, 'DefaultAxesXgrid','on')

set(0,'DefaultAxes Ygrid','on')

Xlabel('rotaçoes motores (rpm)')

Ylabel('PB (kW)') 


\section{ENTRA}

function entra

$\%$ arquivo editavel de entrada de dados do programa ADAPTA - Basta

$\%$ fornecer os valores de dados como indicado nos comentarios

$\%$

\% Carlos Daher Padovezi - 2003

$\%$

global nTrecho nTerminal posTrecho posTerminal calado profundidade ... largura corrente solo nPontes nCurvas nivelVentos nivelOndas ... nivelTroncos nivelNeblina nEclusas nCanais txcarga txdescarga global Lchata Bchata Pchata Tmax nLinhas nColunas nMotor MCR RotNom ... reducao prop_tipo serie diametro AeAo nPas P_D nLemes tipo_Leme ... area_Leme flancos Lemp Bemp Temp Pemp CB_emp CBchata lemes_proa ... bow_thruster KaDuto margem efic_transm espera_carga nChatas_comboio global raioCurva largCurva profCurva corrCurva vaoPonte largPilar ... largPonte profPonte extCanal largCanal profCanal ... atendCanal desvCanal largEclusa compEclusa calEclusa NDM CuOD ... atendEclusa desvEclusa Ntrip IDV lambt Salario_medio rancho_dia global custo_t_term Porc_Duto desmPonte VelCor_x VelCor_y DesmCanal ... tetaPonte Porc_Duto $\%$ $\%$ global nome_saida_compara nome_saida_relato nArq_compara arquivos_compara

$\%$ Entrada dos numeros caracteristicos da via:

nTrecho $=17 ; \%$ numero de trechos em que a via sera dividida (na ida) 
nTerminal $=3 ; \%$ numero de terminais em que a embarcaçao para(ida e volta) nPontes $=9 ; \%$ numero de pontes que passam sobre a via

nCurvas $=0 ; \%$ numero de curvas fechadas na via

nEclusas $=5 ; \%$ numero de eclusas na via

nCanais $=3 ; \%$ numero de canais estreitos na via

$\%$ Entrada das caracteristicas do comboio

Lemp $=19.5 \quad ; \%$ comprimento do empurrador $(\mathrm{m})$

Bemp $=8.23 \quad ; \%$ boca do empurrador $(\mathrm{m})$

Temp $=2.40 \quad ; \%$ calado de operaçao do empurrador $(\mathrm{m})$

Pemp $=2.9 \quad ; \%$ pontal do empurrador $(\mathrm{m})$

CB_emp $=0.636 ; \%$ coeficiente de bloco do empurrador

Lchata $=59.44 ; \%$ comprimento de uma chata $(\mathrm{m})$

Bchata $=10.74 ; \%$ boca de uma chata $(\mathrm{m})$

Pchata $=3.66 ; \%$ pontal das chatas $(\mathrm{m})$

CBchata $=0.915 ; \%$ coeficiente de bloco das chatas

nLinhas $=2 ; \%$ numero de linhas de chatas da formaçao do comboio

nColunas $=2 \quad ; \%$ numero de colunas de chatas da formaçao do comboio

nChatas_comboio=4; \% numero de chatas por comboio (inclui reservas)

$\%$ nChatas_comboio nao deve ser menor que (nLinhas x nColunas)

nMotor $=2 \quad ; \%$ numero de motores/propulsores do empurrador

$\mathrm{MCR}=250 \quad ; \%$ potencia maxima continua de um motor principal $(\mathrm{kW})$

margem $=0.85 ; \%$ fator de utilizaçao do MCR maximo na operaçao

efic_transm $=0.95 ; \%$ eficiencia de transmissao $(=\mathrm{PD} / \mathrm{PB})$

RotNom $=1800 . \quad$; \% rotaçao nominal do(s) motor(es) $(\mathrm{rpm})$

reducao $=6.458 ; \%$ relaçao de reduçao de rotaçoes $(1:$ reducao $)$

prop_tipo $=1 \quad ; \%$ tipo dos propulsores $(1=$ aberto, $2=$ em duto,

$\%$

$3=$ azimutal, $4=$ misto) 
serie $=$ 'Troost' ; \% serie de aproximaçao das caracteristicas dos helices

$\%$ (Troost ou Kaplan)

KaDuto $=0 . \quad ; \%$ KaDuto - geometria do helice Kaplan e tipo de duto:

$\% \quad$ KaDuto 1: Ka 4-70 duto 19a

$\% \quad$ KaDuto 2: Ka 4-70 duto 37

$\% \quad$ KaDuto 3: Ka 4-55 duto 19a

$\% \quad$ KaDuto 4: Ka 3-65 duto 19a

$\% \quad$ KaDuto 5: Ka 5-75 duto 19a

Porc_Duto $=100 . \quad ; \%$ porcentagem do duto que contribui com empuxo

$\%$ (obtem-se, descontando a parte embutida no casco)

diametro $=1.650 ; \%$ diametro dos helices $(\mathrm{m})$

$\mathrm{AeAo}=0.70 \quad ; \%$ razao de area expandida dos helices

nPas $=4 \quad ; \%$ numero de pas dos helices

P_D $=0.77 \quad ; \%$ razao passo / diametro dos helices

nLemes $=2 \quad ; \%$ numero de lemes a re dos propulsores

tipo_Leme $=1 \quad ; \%$ tipo dos lemes $(1=$ convencional, 2 = alto_lift $)$

area_Leme $=2.7 \quad ; \%$ area de cada leme $(\mathrm{m} 2)$

flancos='sim' ;\% existe lemes de flancos? (sim, nao)

lemes_proa='nao' ;\% existe lemes de proa? (sim, nao)

bow_thruster='nao';\% existe bow thruster? (sim, nao)

$\%$ Entrada dos vetores de dados da via e do comboio (vetores sequenciais com

$\%$ dimensoes dadas pelos numeros de trechos e de terminais)

$\%$

$\%$

$\%$ posTrecho(nTrecho) - vetor com as posiçoes do final de cada trecho (em km)

$\% \quad$ os trechos sao definidos entre o terminal de origem

$\% \quad$ e o terminal mais distante (ou seja, apenas na ida) 
$\%$ profundidade(nTrecho)- profundidade media de cada trecho da via (m)

\% largura(nTrecho) - largura media de cada trecho da via (m)

$\%$ corrente(nTrecho) - velocidade de corrente media em cada trecho $(\mathrm{m} / \mathrm{s})$,

$\% \quad$ definida com relaçao ao trajeto de ida: $(+)$ para

$\% \quad$ para descida e (-)para subida do rio

$\%$ solo(nTrecho) - tipo de solo do fundo no trecho, conforme a

$\% \quad$ seguir: 'lodos' ou 'areia' ou 'rocha'

$\%$ nivelVentos(nTrecho) - ocorrencia de ventos em cada trecho (dia/ano)

$\%$ nivelOndas(nTrecho) - ocorrencia de ondas em cada trecho (dia/ano)

$\%$ nivelTroncos(nTrecho) - ocorrencia de acidentes de choques com troncos em

$\% \quad$ cada trecho(choques por 1000 passagens de comboio)

$\%$ nivelNeblina(nTrecho) - ocorrencia de neblina em cada trecho(dia/ano)

$\%$ posTerminal(nTerminal) - vetor com as posiçoes de cada terminal $(\mathrm{km})$.

$\% \quad$ Os terminais sao definidos na ida e na volta. Assim,

$\%$ se o comboio parar em um mesmo terminal tanto na ida

$\% \quad$ como na volta,este tera 2 indices, entre 1 e nTerminal.

$\% \quad$ Lembrar que: $\operatorname{posTerminal}(1)=\operatorname{posTerminal}($ nTerminal $)=0$.

$\%$ calado(nTerminal) - calado das chatas na saida de cada terminal (m)

$\%$ txcarga(nTerminal) - taxa de carga de cada terminal (t/hora)

$\%$ txdescarga(nTerminal) - taxa de descarga de cada terminal (t/hora)

\% espera_carga(nTerminal)- fraçao (0.1 a 1.0) de tempo de carga/descarga em

$\%$ que o empurrador espera por chatas carregadas/vazias.

$\% \quad$ Pode ocorrer das chatas ja se encontrarem prontas, mas,

$\%$ neste caso, ha necessidade de tempo para rearranjo do

$\% \quad$ comboio, para abastecimentos, troca de tripulantes, etc.

\% custo_t_term - custo por tonelada de carga embarcada/desembarcada (reais)

$\%$

$\%$ Atençao: entre os colchetes, separar os dados por espaço, ate 


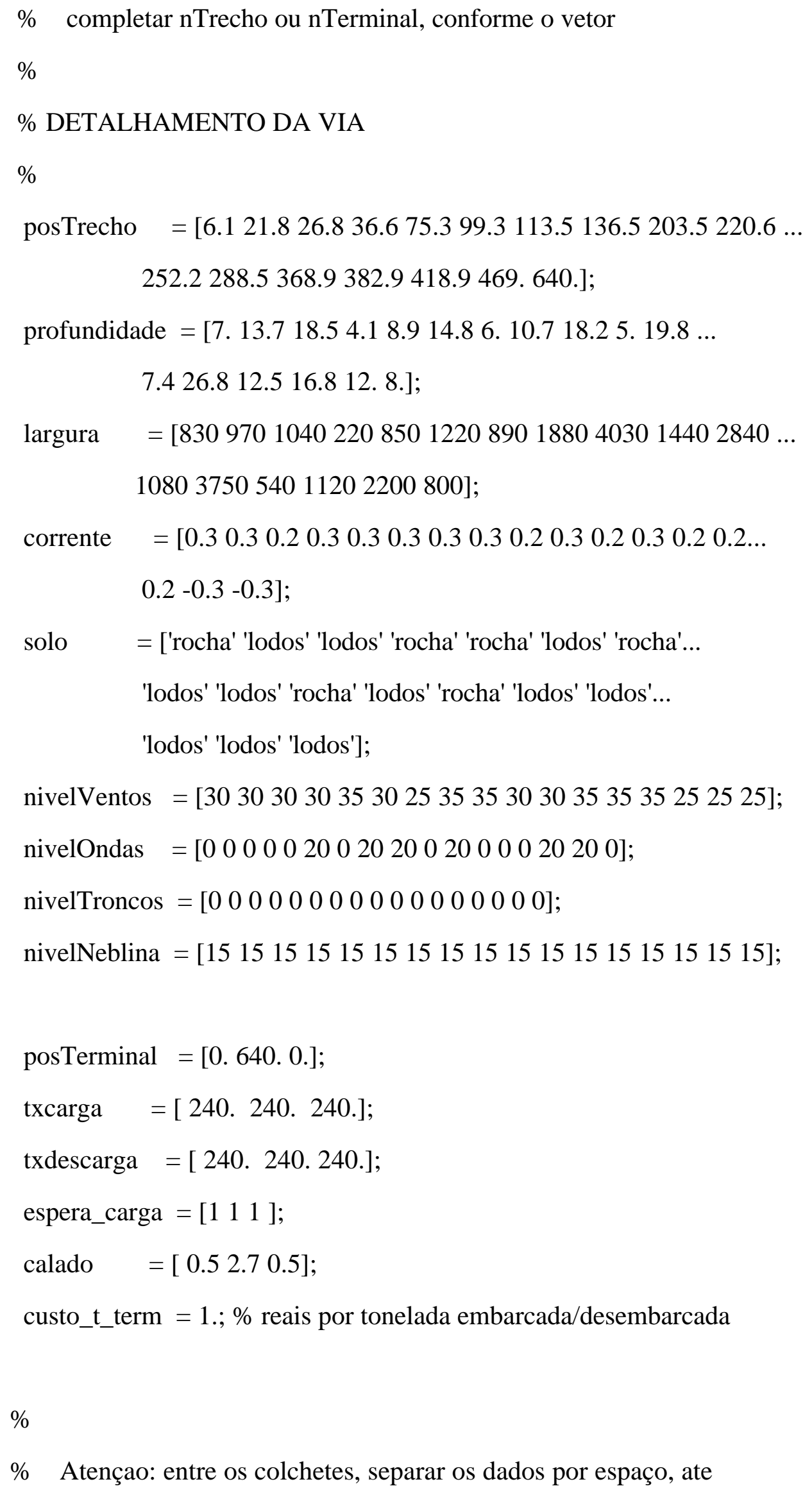




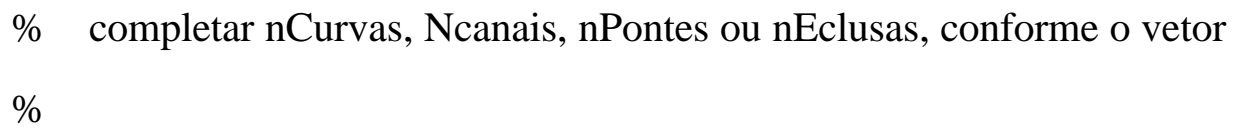




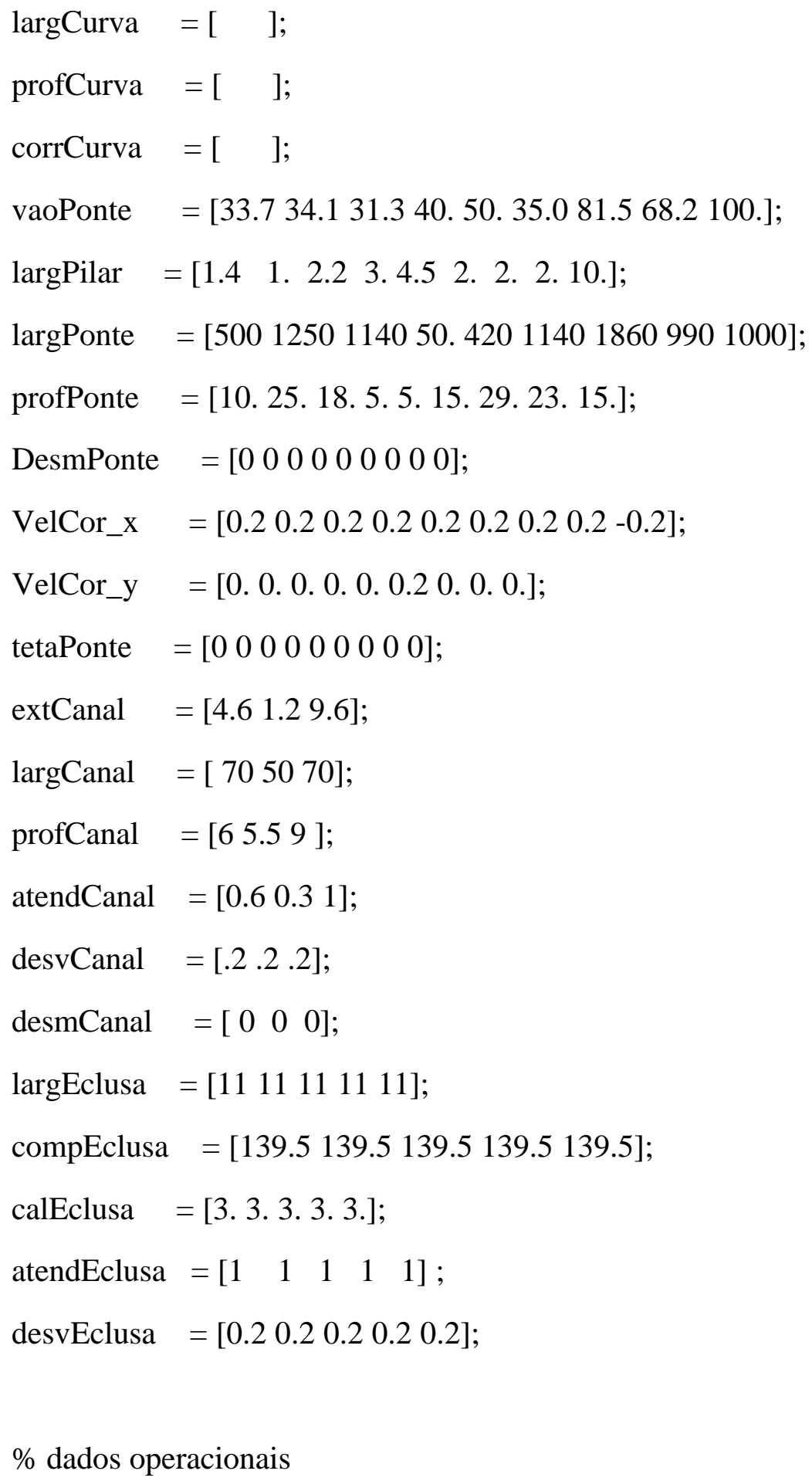

$\%$ dados operacionais

Ntrip $=7 ; \%$ Ntrip - numero de tripulantes do comboio $\mathrm{NDM}=10 ; \% \mathrm{NDM}$ - numero de dias em manutençao anual do comboio lambt $=0.2 ; \%$ lambt - fluxo medio de chegada de embarcaçoes em eclusas $\% \quad$ e canais nos dois sentidos (comboios/hora) 
IDV $=85 ; \%$ IDV - indice de disponibilidade da via (em porcentagem do tempo)

Salario_medio $=600 ; \%$ salario medio dos tripulates $(\mathrm{em}$ reais $)$

rancho_dia $=7 ; \%$ custo da alimentaçao diaria de cada tripulante

$\mathrm{CuOD}=1.2 ; \%$ custo de litro de oleo Diesel (reais/litro)

$\%$

$\%$ arquivos de saidas de dados e opçao de comparaçoes

$\%$

nArq_compara $=0 ; \%$ número de arquivos de dados de processamentos anteriores

$\%$ que se pretende comparar com os resultados atuais

arquivos_compara=' '; \% nomes dos arquivos anteriores para comparaçao

$\%$ com os resultados do processamento atual

nome_saida_compara=' ';\% nome do arquivo para guardar os dados

;\% de comparaçoes (função COMPARA)

nome_saida_relato='HTP_1';\% arquivo de gravaçao dos resultados do programa. 


\section{PROPULSAO}

function propulsao

$\%$ Esta funçao calcula o desempenho do sistema propulsivo em cada trecho

$\%$ da via. A partir dos dados do comboio e das caracteristicas da via,

$\%$ sao calculadas as velocidades e as potencias utilizadas em cada trecho.

$\%$

\% Carlos Daher Padovezi - 2003

$\%$

$\%$

format short $\mathrm{g}$;

global nTrecho nTerminal posTrecho posTerminal calado profundidade ... largura corrente solo nPontes nCurvas nivelVentos nivelOndas ... nivelTroncos nivelNeblina nEclusas nCanais txcarga txdescarga global Lchata Bchata Pchata Tmax nLinhas nColunas nMotor MCR RotNom ... reducao prop_tipo serie diametro AeAo nPas P_D nLemes tipo_Leme ... area_Leme flancos Lemp Bemp Temp Pemp CB_emp CBchata lemes_proa ... bow_thruster KaDuto efic_transm B Porc_Duto global raioCurva largCurva profCurva corrCurva vaoPonte largPilar ... largPonte profPonte extCanal largCanal profCanal ... atendCanal desvCanal largEclusa compEclusa calEclusa ... atendEclusa desvEclusa cal i_forma Dt margem Vct ht Wt global Vreal rpmMotor PBt eficProp Vt Rt empuxo_Vo \% comboios: [ $\left.\begin{array}{llllllll}1 \times 1 & 1 \times 2 & 2 \times 1 & 1 \times 3 & 2 \times 2 & 2 \times 3 & 3 \times 2 & >6\end{array}\right]$ w_prof $=\left[\begin{array}{llllllll}0.26 & 0.29 & 0.30 & 0.29 & 0.25 & 0.33 & 0.40 & 0.45\end{array}\right]$; w_raso $=\left[\begin{array}{llllllll}0.23 & 0.22 & 0.25 & 0.22 & 0.32 & 0.33 & 0.40 & 0.45\end{array}\right]$; t_prof $=\left[\begin{array}{llllllll}0.27 & 0.25 & 0.24 & 0.25 & 0.18 & 0.25 & 0.25 & 0.25\end{array}\right]$; t_raso $=\left[\begin{array}{llllllll}0.27 & 0.25 & 0.24 & 0.25 & 0.19 & 0.25 & 0.25 & 0.25\end{array}\right] ;$ 


$$
\begin{aligned}
& \mathrm{w}_{\text {_vazio }}=\left[\begin{array}{llllllll}
0.20 & 0.20 & 0.20 & 0.20 & 0.20 & 0.20 & 0.20 & 0.20
\end{array}\right] ; \\
& \text { t_vazio }=\left[\begin{array}{llllllll}
0.20 & 0.20 & 0.20 & 0.20 & 0.20 & 0.20 & 0.20 & 0.20
\end{array}\right] ; \\
& \text { err_prof }=\left[\begin{array}{llllllll}
1.00 & 1.00 & 1.00 & 1.00 & 0.98 & 1.00 & 1.00 & 1.05
\end{array}\right] \text {; }
\end{aligned}
$$

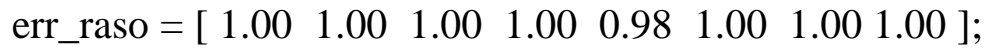

$\%$ i_forma $=$ numero $($ de 1 a 8 ) de sequencia da formaçao do comboio:

$\%$ na ordem: uma chata, duas chatas em linha, 2 em paralelo,

$\% 3$ chatas em linha, 4 chatas $2 \times 2$,

$\% 6$ chatas $2+2+2,6$ chatas $3+3$, formaçoes maiores

$\%$ efic_transm - eficiencia de transmissao (=PD/PB)

$\%$ margem - porcentagem da potencia MCR do motor a ser utilizada

$\%$ calculo da potencia efetiva do casco em cada trecho

if $\mathrm{nLinhas}==1 \&$ nColunas $==1$

i_forma $=1$;

$\mathrm{L}=$ Lchata + Lemp;

elseif $\mathrm{nLinhas}==1 \&$ nColunas $==2$

i_forma $=2$;

$\mathrm{L}=$ nColunas $*$ Lchata + Lemp;

elseif $\mathrm{nLinhas}==2 \&$ nColunas $==1$

i_forma $=3$;

$\mathrm{L}=$ nColunas $*$ Lchata;

elseif nLinhas $==1 \&$ nColunas $==3$

i_forma $=4$;

$\mathrm{L}=$ nColunas $*$ Lchata + Lemp;

elseif $\mathrm{nLinhas}==2 \&$ nColunas $==2$ 


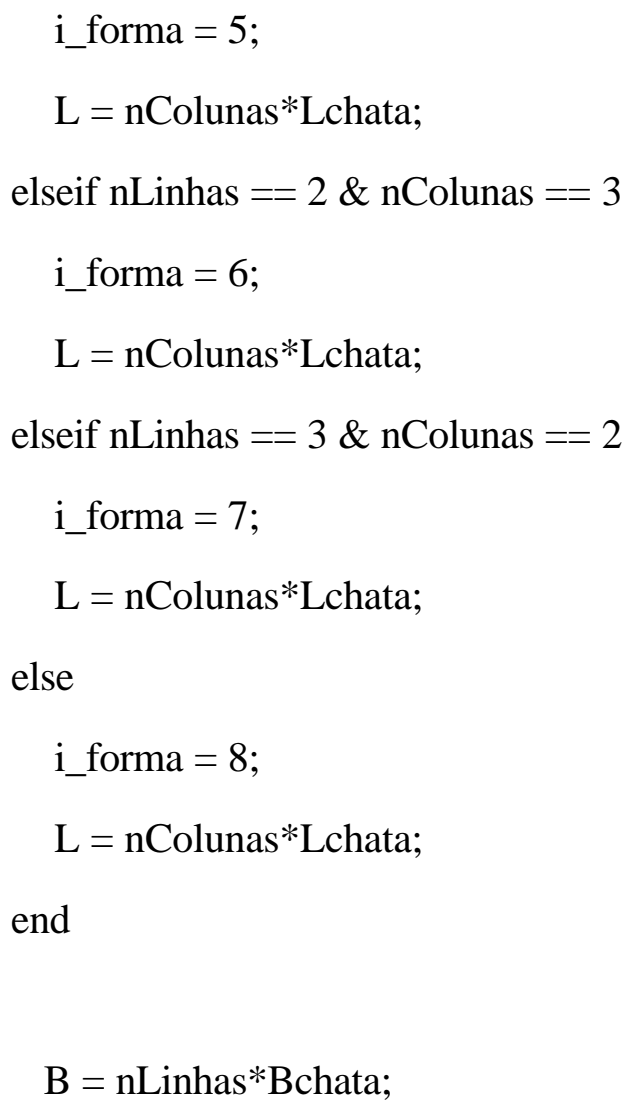

if lemes_proa $==$ 'sim' $\%$ computo do efeito da presença de lemes de proa

$$
\mathrm{fff}=1.04
$$

else

$$
\mathrm{fff}=1 \text {; }
$$

end

rpmMotor $=$ zeros $(1,2 *$ nTrecho $) ;$

Vreal $=\operatorname{zeros}(1,2 *$ nTrecho $)$

$\mathrm{PBt}=\operatorname{zeros}(1,2 *$ nTrecho $)$

rps_max=RotNom/reducao/60.;

Qmax $=$ MCR $* 102 *$ margem*efic_transm/(2*pi*rps_max $)$;

if serie $==$ 'Troost'

[KT_J0,KQ_J0,bbb]=btroost(0,P_D,AeAo,nPas); else 
[KT_J0,aaa,KQ_J0,ccc]=kaplan(0,P_D,KaDuto,Porc_Duto);

end

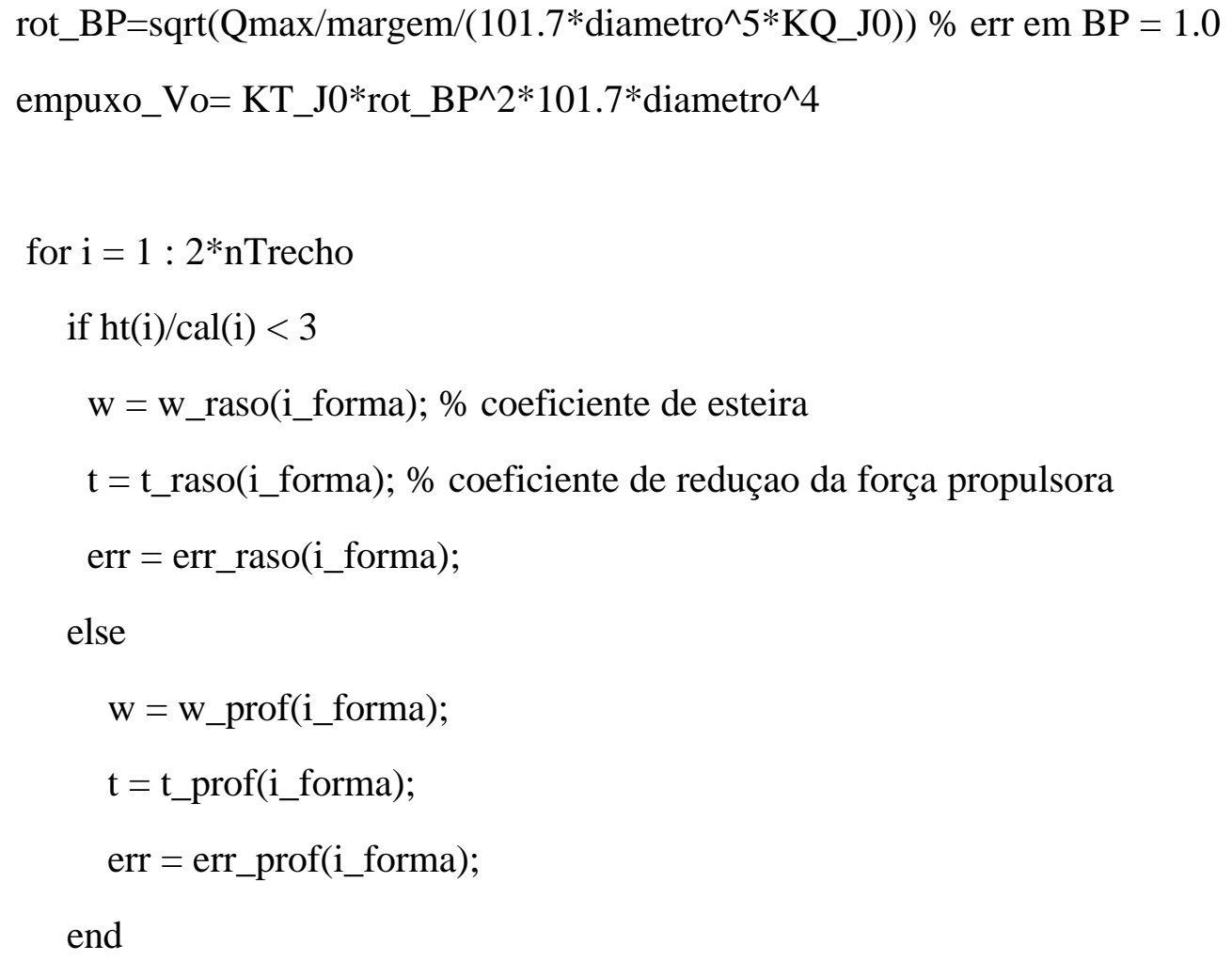




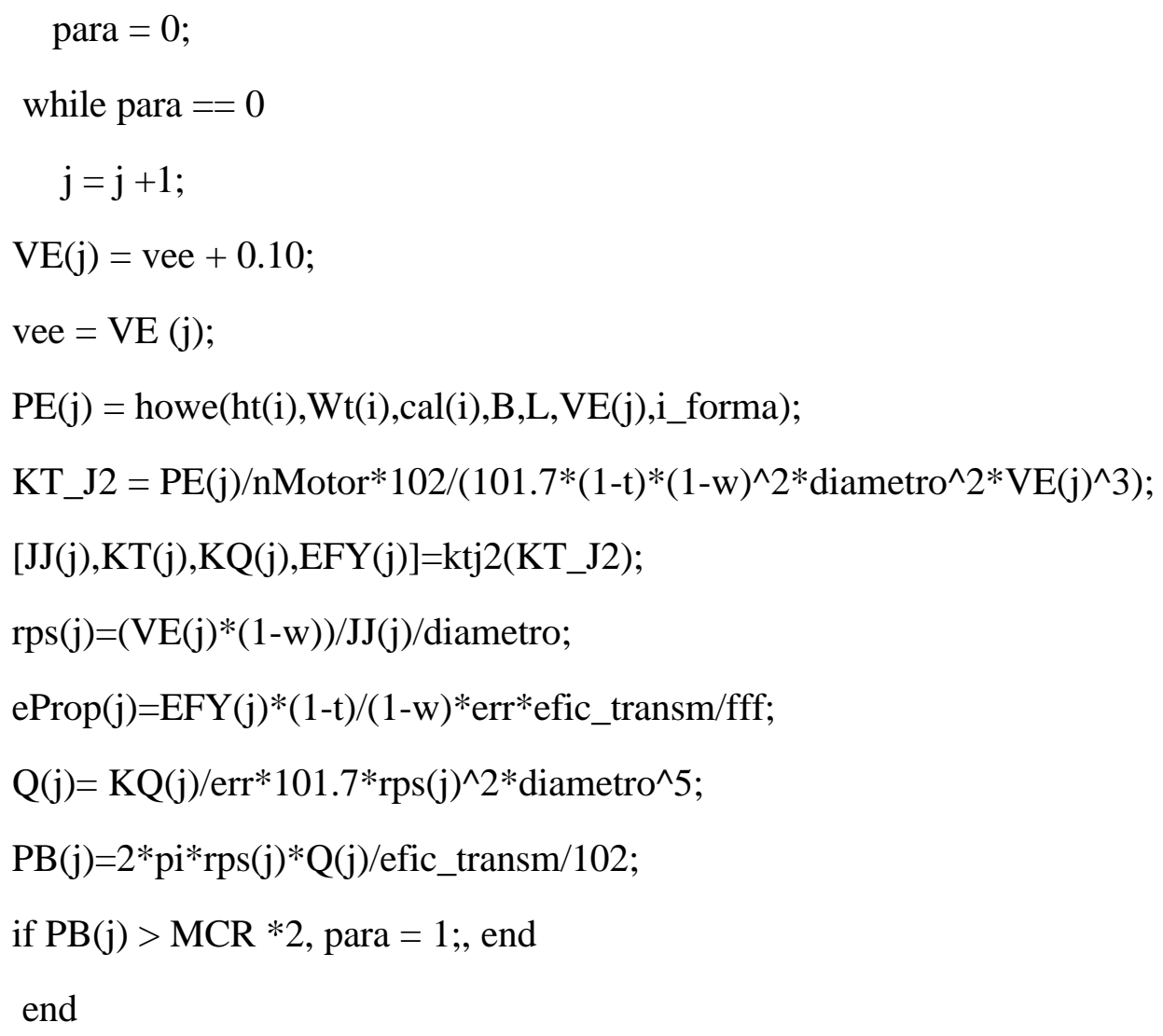




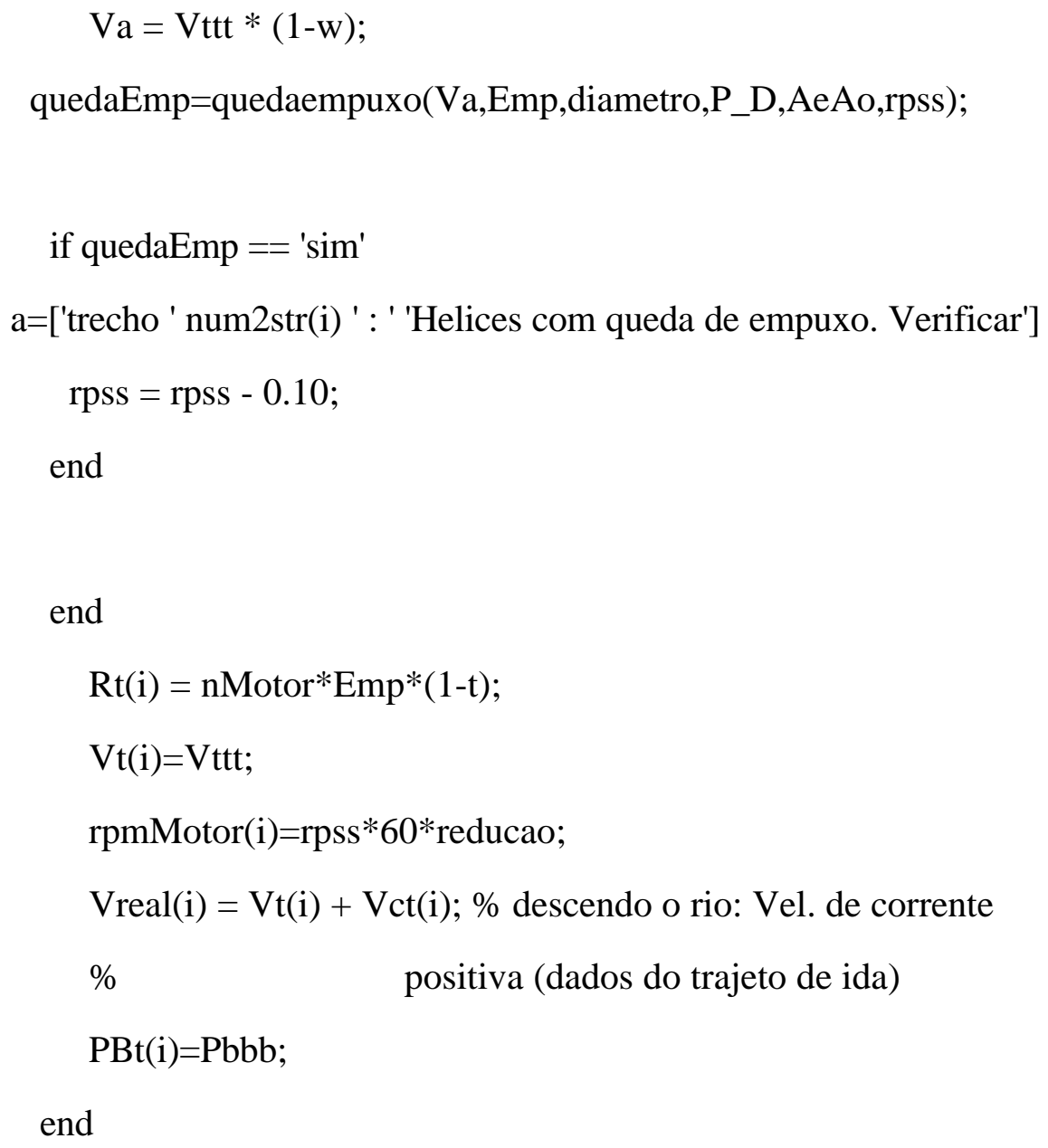




\section{BTROOST}

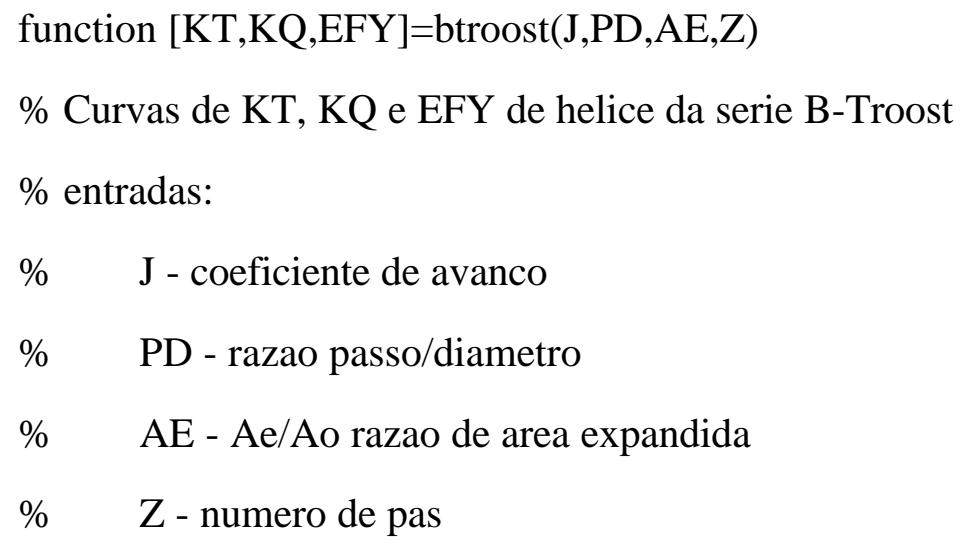




$$
\begin{aligned}
& \mathrm{UKT}=\left[\begin{array}{lllllllll}
0 & 0 & 0 & 0 & 1 & 1 & 1 & 0 & 0
\end{array} \ldots\right. \\
& \begin{array}{llllllllll}
0 & 0 & 1 & 1 & 0 & 0 & 0 & 1 & 2 \ldots
\end{array} \\
& \begin{array}{llllllllll}
2 & 2 & 2 & 2 & 0 & 0 & 0 & 1 & 2 \ldots
\end{array} \\
& \begin{array}{llllllllll}
2 & 0 & 0 & 0 & 0 & 0 & 0 & 0 & 1 \ldots
\end{array} \\
& \left.\begin{array}{lll}
1 & 1 & 2
\end{array}\right] ; \\
& \mathrm{VKT}=\left[\begin{array}{llllllllll}
0 & 0 & 0 & 0 & 0 & 0 & 0 & 1 & 1 \ldots
\end{array}\right. \\
& \begin{array}{llllllllll}
1 & 1 & 1 & 1 & 0 & 0 & 0 & 0 & 0 & \ldots
\end{array} \\
& \begin{array}{lllllllllll}
0 & 0 & 0 & 0 & 1 & 1 & 1 & 1 & 1 & \ldots
\end{array} \\
& \begin{array}{llllllllll}
1 & 2 & 2 & 2 & 2 & 2 & 2 & 2 & 2 \ldots
\end{array} \\
& \left.\begin{array}{lll}
2 & 2 & 2
\end{array}\right] \text {; }
\end{aligned}
$$

$\%$ Coeficientes de KQ

$$
\begin{aligned}
& \mathrm{CKQ}=\left[\begin{array}{lllllll}
0.00379363 & 0.00886523 & -0.032241 & 0.00344778 & -0.0408811 & \ldots
\end{array}\right. \\
& \begin{array}{lllllll}
-0.108009 & -0.0885381 & 0.188561 & -0.00370871 & 0.00513696 & \ldots
\end{array} \\
& \begin{array}{lllllll}
0.0209449 & 0.00474319 & -0.00723408 & 0.00438388 & -0.0269403 & \ldots
\end{array} \\
& \begin{array}{llllll}
0.0558062 & 0.0161886 & 0.00318086 & 0.015896 & 0.0471729 & \ldots
\end{array} \\
& \begin{array}{llllll}
0.0196283 & -0.0502782 & -0.030055 & 0.0417122 & -0.0397722 & \ldots
\end{array} \\
& \begin{array}{llllll}
-0.00350024 & -0.0106854 & 0.00110903 & -0.000313912 & 0.0035985 & \ldots
\end{array} \\
& \begin{array}{lllllll}
-0.00142121 & -0.00383637 & 0.0126803 & -0.00318278 & 0.00334268 & \ldots
\end{array} \\
& \begin{array}{lllllll}
-0.00183491 & 0.000112451 & -2.97228 \mathrm{e}-005 & 0.000269551 & 0.00083265 & \ldots
\end{array} \\
& \begin{array}{llllll}
0.00155334 & 0.000302683 & -0.0001843 & -0.000425399 & 8.69243 e-005 & \ldots
\end{array} \\
& -0.0004659 \quad 5.54194 \mathrm{e}-005] \text {; }
\end{aligned}
$$$$
\mathrm{SKQ}=\left[\begin{array}{llllllllll}
0 & 2 & 1 & 0 & 0 & 1 & 2 & 0 & 1 \ldots
\end{array}\right.
$$$$
\begin{array}{llllllllll}
0 & 1 & 2 & 2 & 1 & 0 & 3 & 0 & 1 \ldots
\end{array}
$$$$
\begin{array}{llllllllll}
0 & 1 & 3 & 0 & 3 & 2 & 0 & 0 & 3 \ldots
\end{array}
$$$$
\begin{array}{llllllllll}
3 & 0 & 3 & 0 & 1 & 0 & 2 & 0 & 1 & \ldots
\end{array}
$$$$
\begin{array}{llllllllll} 
& 3 & 3 & 1 & 2 & 0 & 0 & 0 & 0 & 3
\end{array}
$$$$
\left.\begin{array}{ll}
0 & 1
\end{array}\right] \text {; }
$$

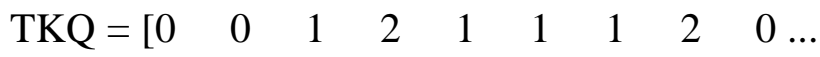

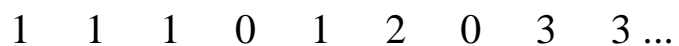




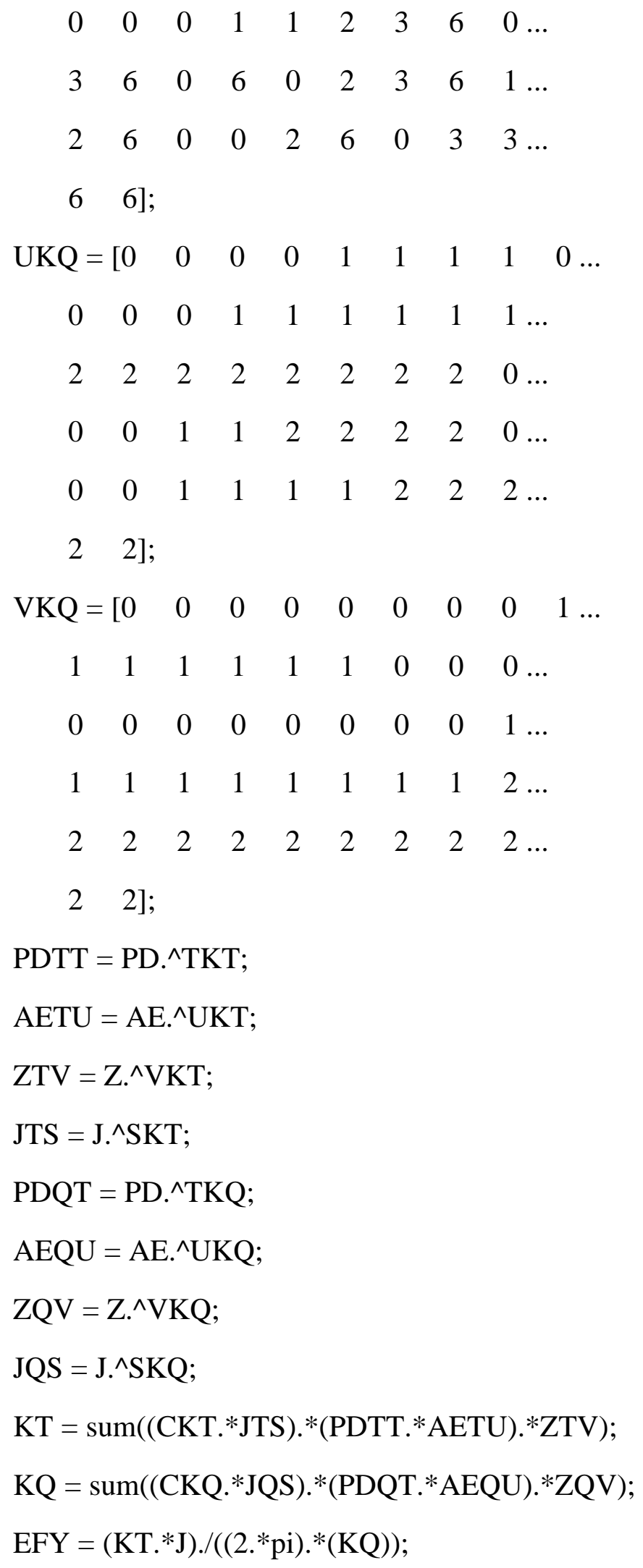




\section{KAPLAN}

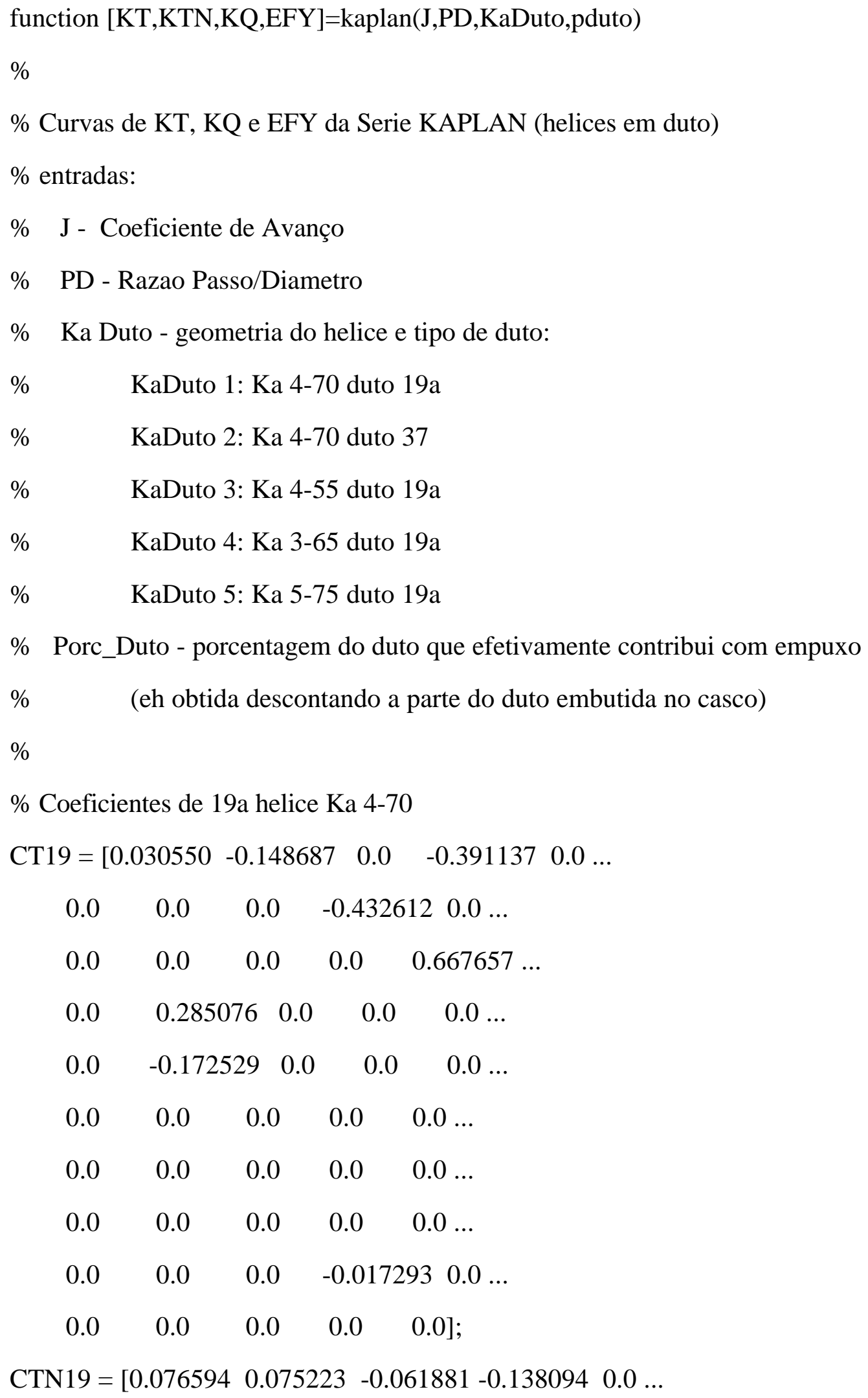




$$
\begin{aligned}
& \begin{array}{llllll}
-0.370620 & 0.323447 & -0.271337 & -0.687921 & 0.225189 & \ldots
\end{array} \\
& \begin{array}{lllll}
0.0 & 0.0 & 0.0 & -0.081101 & 0.666028
\end{array} \ldots \\
& \begin{array}{lllll}
0.0 & 0.734285 & 0.0 & 0.0 & 0.0 \ldots
\end{array} \\
& \begin{array}{llllll}
0.0 & -0.202467 & 0.0 & -0.542490 & 0.0 \ldots
\end{array} \\
& \begin{array}{lllll}
0.0 & 0.0 & -0.016149 & 0.0 & 0.0 \ldots
\end{array} \\
& \begin{array}{lllll}
0.0 & 0.099819 & 0.0 & 0.0 & 0.0 \ldots
\end{array} \\
& \begin{array}{lllll}
0.0 & 0.030084 & 0.0 & 0.0 & 0.0 \ldots
\end{array} \\
& \begin{array}{lllll}
0.0 & 0.0 & 0.0 & 0.0 & -0.001876 \ldots
\end{array} \\
& \left.\begin{array}{lllll}
0.0 & 0.0 & 0.0 & 0.0 & 0.0
\end{array}\right] \\
& \mathrm{CQ19}=\left[\begin{array}{lllll}
0.006735 & 0.0 & -0.016306 & 0.0 & -0.007244 \ldots
\end{array}\right. \\
& \begin{array}{lllll}
0.0 & 0.0 & 0.0 & 0.0 & -0.024012 \ldots
\end{array} \\
& \begin{array}{lllll}
0.0 & 0.0 & 0.0 & 0.0 & 0.0 \ldots
\end{array} \\
& \begin{array}{lllll}
0.0 & 0.005193 & 0.0 & 0.0 & 0.0 \ldots
\end{array} \\
& \begin{array}{lllll}
0.0 & 0.046605 & 0.0 & 0.0 & 0.0 \ldots
\end{array} \\
& \begin{array}{llllll}
0.0 & 0.0 & 0.0 & -0.007366 & 0.0 \ldots
\end{array} \\
& \begin{array}{lllll}
0.0 & 0.0 & 0.0 & 0.0 & 0.0 \ldots
\end{array} \\
& \begin{array}{lllll}
0.0 & 0.0 & 0.0 & 0.0 & 0.0 \ldots
\end{array} \\
& \begin{array}{llllll}
0.0 & 0.0 & -0.001730 & -0.000337 & 0.000861 \ldots
\end{array} \\
& \left.\begin{array}{lllll}
0.0 & 0.0 & 0.0 & 0.0 & 0.0
\end{array}\right] ;
\end{aligned}
$$

$\%$ Coeficientes de duto 37 helice Ka 4-70

$$
\begin{array}{cccccc}
\text { CT37 } & =[-0.162557 & 0.0 & 0.0 & 0.0 & -0.077387 \ldots \\
0.0 & 0.0 & 0.598107 & -1.009030 & 0.0 \ldots \\
0.0 & 0.0 & 0.0 & 0.0 & 0.085087 \ldots \\
0.425585 & 0.0 & 0.0 & 0.0 & 0.0 \ldots \\
0.0 & 0.0 & 0.0 & 0.0 & 0.0 \ldots \\
0.0 & -0.021044 & 0.0 & 0.042997 & 0.0 \ldots \\
0.0 & 0.0 & 0.0 & 0.0 & 0.0 \ldots & \\
0.0 & -0.038383 & 0.0 & 0.0 & 0.0 \ldots \\
0.0 & 0.0 & 0.0 & 0.0 & 0.014992 \ldots
\end{array}
$$




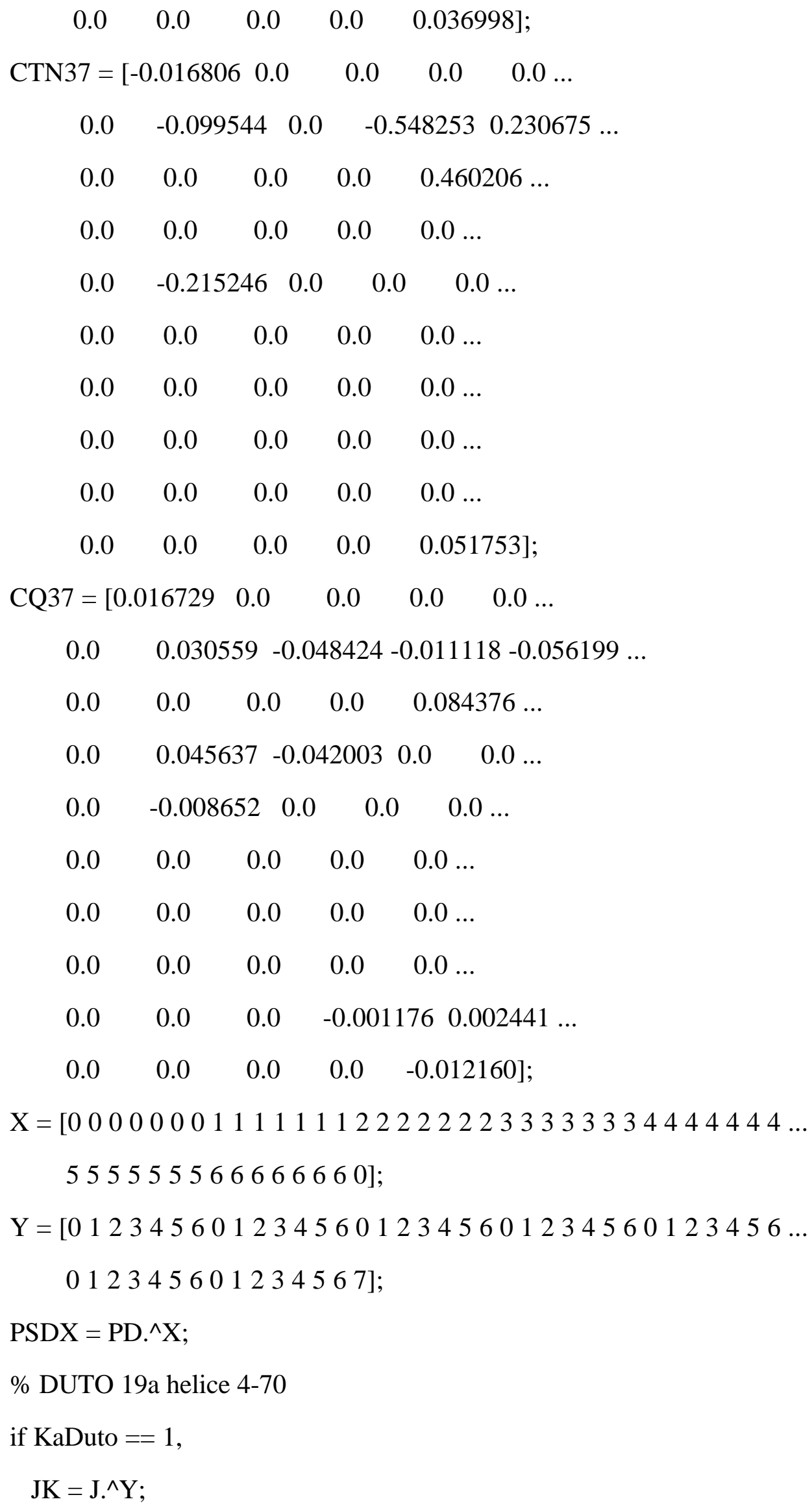




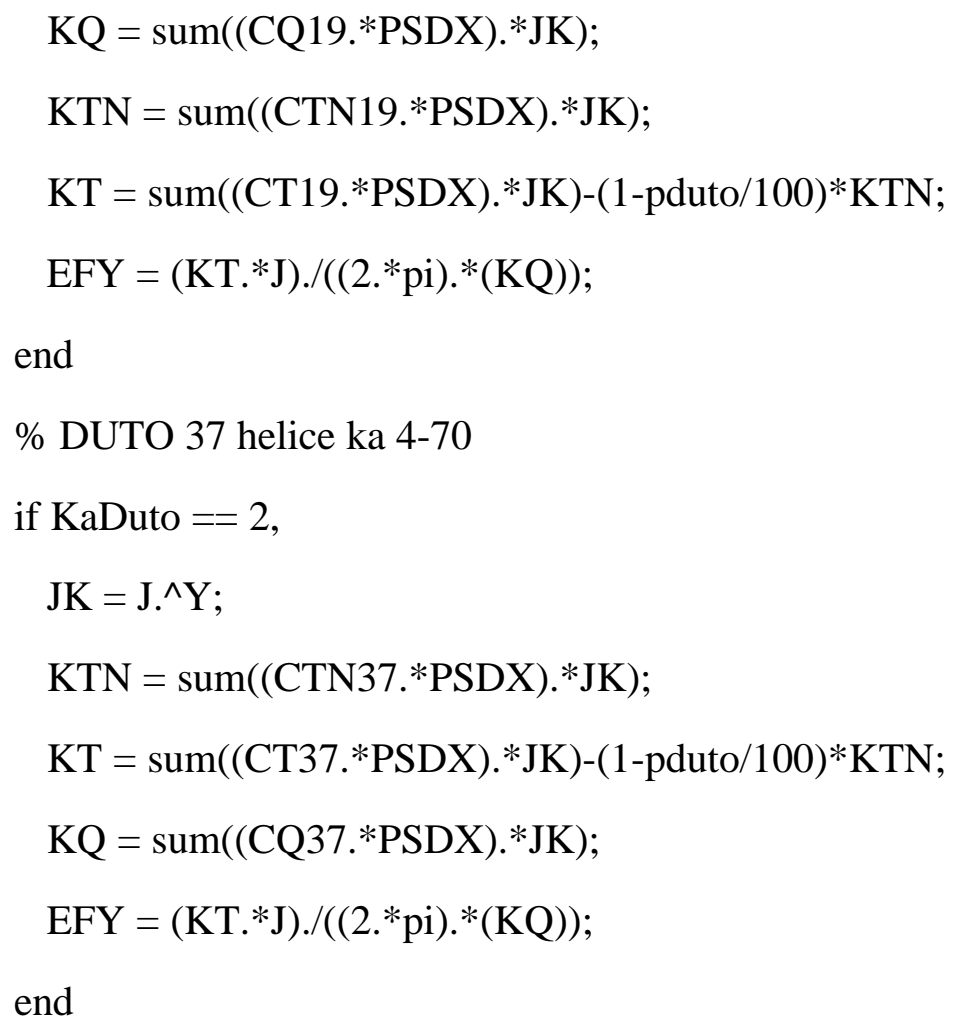


$-0.994962 * \mathrm{PD}^{\wedge} 4+0.015742 * \mathrm{PD}^{\wedge} 5 * \mathrm{~J}+0.043782 * \mathrm{PD}^{\wedge} 6-2.74693 * \mathrm{~J}^{\wedge} 3 \ldots$

-(1-pduto/100)*KTN;

$\mathrm{EFY}=\left(\mathrm{KT} \cdot{ }^{*} \mathrm{~J}\right) . /\left(\left(2 \cdot{ }^{*} \mathrm{pi}\right) . *(\mathrm{KQ})\right) ;$

end

$\%$

$\% \quad$ DUTO 19a helice Ka 3-65

if KaDuto == 4,

$\mathrm{KQ}=0.00636-0.017942 * \mathrm{~J}^{\wedge} 2-0.008089 * \mathrm{~J}^{\wedge} 4-0.016644 * \mathrm{PD} * \mathrm{~J}^{\wedge} 2+0.040041 * \ldots$

$\mathrm{PD}^{\wedge} 3+\mathrm{PD}^{\wedge} 6 *\left(-0.00346-0.000674 * \mathrm{~J}+0.001721 * \mathrm{~J}^{\wedge} 2\right) ;$

$\mathrm{KTN}=0.154+0.11556 * \mathrm{~J}-0.123761 * \mathrm{~J}^{\wedge} 2-0.74124 * \mathrm{~J} \wedge 5+0.646894 * \mathrm{~J}^{\wedge} 6-\ldots$

$0.542674 * \mathrm{PD}-0.749643 * \mathrm{PD} * \mathrm{~J}-0.162202 * \mathrm{PD}^{*} \mathrm{~J}^{\wedge} 6+0.972388 * \mathrm{PD}^{\wedge} 2+1.46857 \ldots$

$* \mathrm{PD}^{\wedge} 2 * \mathrm{~J}^{\wedge} 2-0.317644 * \mathrm{PD}^{\wedge} 3-1.08498 * \mathrm{PD}^{\wedge} 3 * \mathrm{~J}^{\wedge} 2-0.032298 * \mathrm{~J}^{\wedge} 6 * \mathrm{PD}^{\wedge} 3 \ldots$

$+0.199637 * \mathrm{PD}^{\wedge} 4 * \mathrm{~J}^{\wedge} 3+0.060168 * \mathrm{PD}^{\wedge} 5^{*} \mathrm{~J}$

$\mathrm{KT}=0.0281-0.14391 * \mathrm{~J}-0.383783 * \mathrm{~J}^{\wedge} 3-0.429709 * \mathrm{~J} * \mathrm{PD}+0.671268 * \mathrm{PD}^{\wedge} 2+\ldots$

$0.286926 * \mathrm{PD}^{\wedge} 2 * \mathrm{~J}^{\wedge} 2-0.182294 * \mathrm{PD}^{\wedge} 3-0.017378 * \mathrm{PD}^{\wedge} 6 * \mathrm{~J}-(1-$ pduto/100)*KTN;

$\mathrm{EFY}=\left(\mathrm{KT} .{ }^{*} \mathrm{~J}\right) . /((2 . * \mathrm{pi}) . *(\mathrm{KQ})) ;$

end

$\%$

\% DUTO 19a helice Ka 5-75

if KaDuto $==5$,

$\mathrm{KQ}=0.007210-0.01467 * \mathrm{~J}^{\wedge} 2-0.006398 * \mathrm{~J}^{\wedge} 4-0.03138 * \mathrm{PD}^{*} \mathrm{~J}^{\wedge} 2+0.010386 * \ldots$

$\mathrm{PD}^{\wedge} 2 * \mathrm{~J}^{\wedge} 2+0.053169 * \mathrm{PD}^{\wedge} 3-0.014731 * \mathrm{PD}^{\wedge} 4 ;$

$\mathrm{KTN}=-0.000813+0.034885 * \mathrm{~J}-0.276187 * \mathrm{~J} \wedge 3-0.626198 * \mathrm{PD} * \mathrm{~J}+0.450379 * \ldots$

$\mathrm{PD} * \mathrm{~J}^{\wedge} 2+0.359718 * \mathrm{PD}^{\wedge} 2-0.087289 * \mathrm{PD}^{\wedge} 3-0.003751 * \mathrm{PD}^{\wedge} 6 * \mathrm{~J}^{\wedge} 2$;

$\mathrm{KT}=0.033-0.153463 * \mathrm{~J}-0.398491 * \mathrm{~J} \wedge 3-0.435515 * \mathrm{PD} * \mathrm{~J}+0.664045 * \mathrm{PD}^{\wedge} 2+\ldots$

$0.283225 * \mathrm{PD}^{\wedge} 2 * \mathrm{~J}^{\wedge} 2-0.162764 * \mathrm{PD}^{\wedge} 3-0.017208 * \mathrm{PD}^{\wedge} 6 * \mathrm{~J}-(1-$ pduto/100)*KTN;

$\mathrm{EFY}=(\mathrm{KT} . * \mathrm{~J}) . /((2 . * \mathrm{pi}) . *(\mathrm{KQ})) ;$

end 


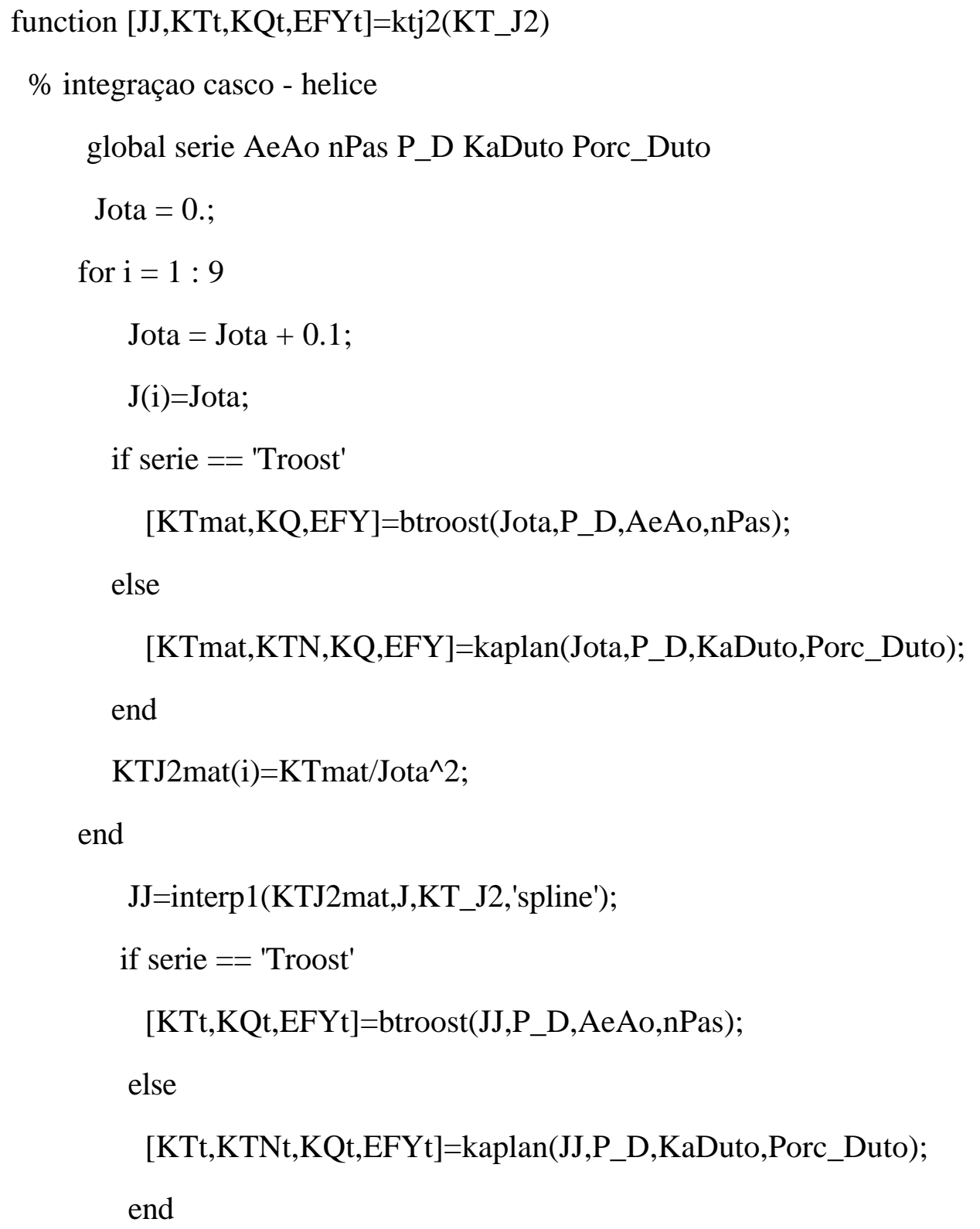




\section{QUEDAEMPUXO}

function [quedaEmp]=quedaempuxo(Va,Emp,D,P_D,AeAo,nRot)

$\%$ estimativa de quantidade de cavitaçao no dorso das pas de um helice

$\%$

\%ENTRADAS:

$\%$ Va - VELOCIDADE DE AVANÇO (m/s)

$\%$ Emp - EMPUXO DO HELICE (kgf)

$\%$ D - DIAMETRO DO HELICE (m)

$\%$ P_D - RAZAO PASSO / DIAMETRO

$\%$ AeAo - RAZAO DE AREA EXPANDIDA

$\%$ nRot - NUMERO DE ROTAÇOES DO HELICE (rps)

$\%$

\%SAIDA:

\% quedaEmp - (sim ou nao) - indica se ha queda de empuxo ou nao.

Patm $=10000 . ; \%$ pressao atmosferica $=10000 \mathrm{kgf} / \mathrm{m} 2$ (media, adotado)

$\mathrm{Pv}=250 ; \%$ pressao de vaporizaçao da agua $=250 \mathrm{kgf} / \mathrm{m} 2$ (media, adotado)

ro $=101.7 ; \%$ densidade da agua doce em $\mathrm{kgf.s} 2 / \mathrm{m} 4(\mathrm{ro}=\mathrm{gama} / \mathrm{g})$

imersao $=0.75 * \mathrm{D} ; \%$ imersao do eixo do helice $(\mathrm{m})($ assumido como $=0,75 . \mathrm{D})$

$\%$

$\%$ area projetada das pas do helice

$$
\text { Ap }=\left(1.067-0.229 * \mathrm{P} \_\mathrm{D}\right) *\left(\mathrm{AeAo} * \mathrm{pi} * \mathrm{D}^{\wedge} 2 / 4\right) ;
$$

$\%$ Velocidade resultante nas pas

$$
\mathrm{Vr}=\operatorname{sqrt}\left(\mathrm{Va}^{\wedge} 2+\left(\mathrm{pi}{ }^{*} \mathrm{nRot} * \mathrm{D}^{*} 0.7\right)^{\wedge} 2\right) ;
$$

$\%$ indice de cavitaçao

$$
\text { sigma }=(\mathrm{Patm}-\mathrm{Pv}+\mathrm{ro} * 9.81 * \text { imersao }) /\left(0.5 * \mathrm{ro}^{*} \mathrm{Vr}^{\wedge} 2\right) ;
$$

$\%$ TalC limite de cavitaçao para nao ocorrer queda de empuxo

TalcLimite $=0.70 *$ sigma; 


\section{PARADABRUSCA}

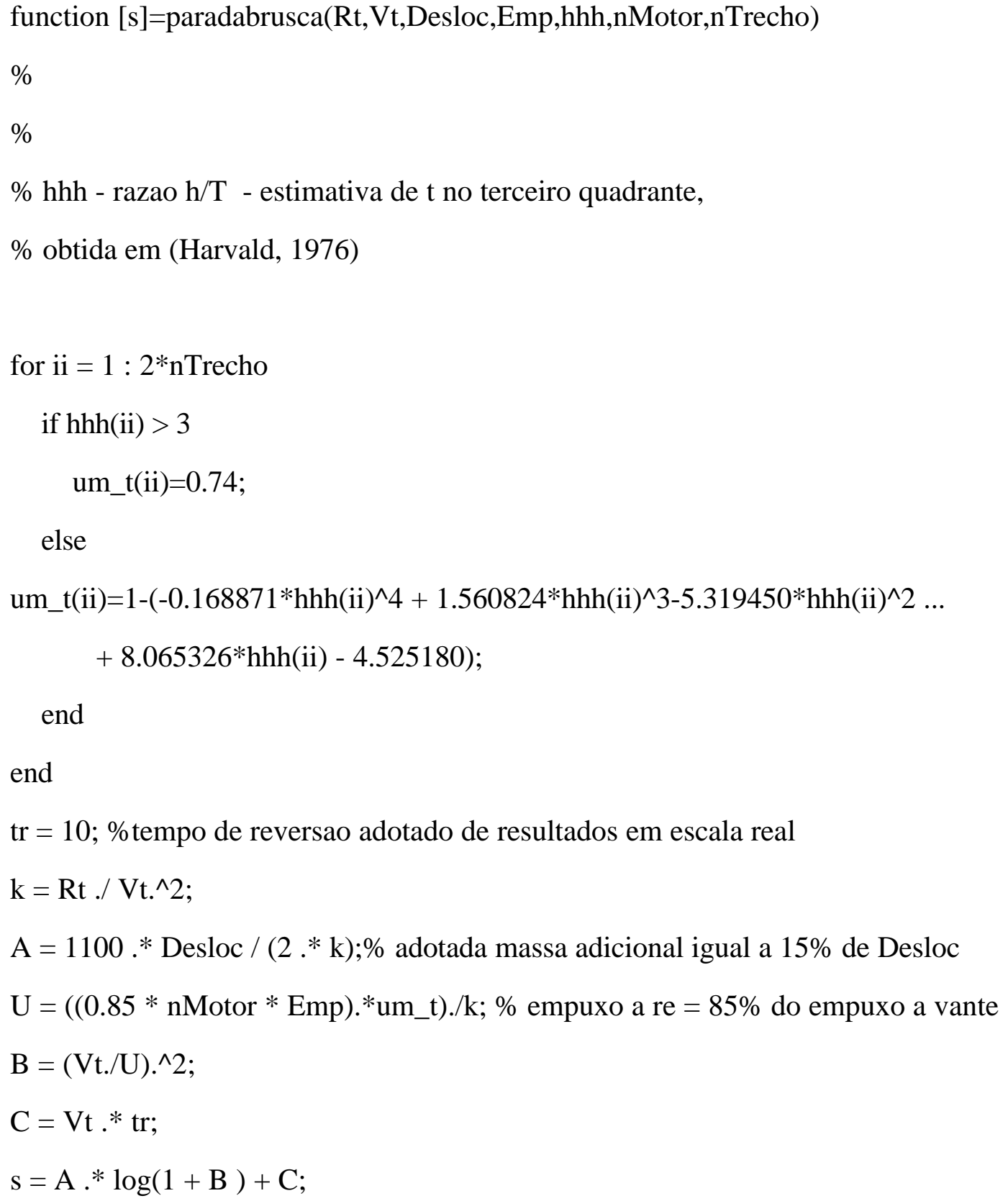




\section{DESMEMBRA}

function [num_desmem,tempo_desmem]=desmembra(Dlarg,Dcompr,Datend,nnn)

$\%$ esta funçao calcula tempos adicionais de passagens sob pontes,

$\%$ por eclusas, por canais ou por outros pontos criticos em que

$\%$ haja necessidade de ocorrer desmembramentos do comboio

$\%$ para garantia de segurança da navegaçao

$\%$

global nColunas nLinhas Lchata Bchata compEmp

$\%$ entradas:

$\%$ do comboio: nColunas, nLinhas, Lchata, Bchata, compEmp

\% (largCanal, extCanal, atendCanal) no caso de verificaçao de canal ou

\% (largEclusa, compEclusa, atendEclusa) no caso de verificaçao de eclusas

$\%$ nnn - numero de pontes ou de canais

$\%$

\%saidas:

$\%$ num_desmem - numero de desmembramentos

\% tempo_desmem - tempo adicional necessario ao desmembramento (horas)

$\%$

\% VERIFICAÇAO DE NECESSIDADES DE DESMEMBRAMENTOS

num_desmem=zeros $(1, \mathrm{nnn})$;

tempo_desmem=zeros $(1, \mathrm{nnn})$;

for $\mathrm{i}=1: \mathrm{nnn}$

compr $=($ nColunas $*$ Lchata $)+$ compEmp;

col=nColunas;

$\operatorname{larg}=($ nLinhas $*$ Bchata $)$;

lin=nLinhas;

while compr $>$ Dcompr(i)

$\mathrm{col}=\mathrm{col}-1$ 
compr $=$ col $*$ Lchata + compEmp;

end

while larg > Dlarg(i)

$\operatorname{lin}=\operatorname{lin}-1$;

$\operatorname{larg}=\operatorname{lin} *$ Bchata;

end

num_desmem $(\mathrm{i})=\operatorname{ceil}(($ nColunas*nLinhas $) /(\operatorname{lin} *$ col $)) ;$

tempo_desmem $(\mathrm{i})=(2 *$ num_desmem $(\mathrm{i})-1) *($ Datend $(\mathrm{i})+0.5)$;

end 


\section{ECLUSAS_CANAIS}

function [TAdn,TAdp]=eclusas_canais

$\%$ esta funçao calcula os tempos gastos de passagens em eclusas

$\%$ e em canais. Sao levados em conta os tempos de espera e os

$\%$ tempos adicionais em possiveis desmembramentos do comboio

$\%$

$\%$

global nColunas nLinhas Lchata Bchata compEmp compEclusa largEclusa ...

calEclusa largCanal profCanal extCanal nCanais nEclusas

global TSistE TEspE desmCanal desmEclusa tempoDesmemCanal ...

tempoDesmemEclusa TSistC TEspC lambt

global atendCanal atendEclusa desvCanal desvEclusa desmPonte VelCor_x ...

VelCor_y DesmCanal

$\%$

$\%$ entradas:

\% lambt - fluxo medio de chegada de embarcaçoes em eclusas/canais

$\%$ nos dois sentidos (comboios/hora)

\%saidas:

$\%$ num_desmem - numero de desmembramentos

\% tempo_desmem - tempo adicional necessario ao desmembramento (horas)

$\%$

warning off MATLAB:divideByZero

$\%$ canais

desmCanal=zeros( 1 ,nCanais $)$;

tempoDesmemCanal=zeros(1,nCanais);

desmEclusa $=$ zeros $(1$, nEclusas $)$;

tempoDesmemEclusa=zeros $(1$, nEclusas $)$;

congCanal=lambt.*atendCanal; 
C2S_Canal=desvCanal./atendCanal;

inb=isinf(C2S_Canal);

inc=isnan(C2S_Canal);

C2S_Canal(inb) $=0$;

C2S_Canal(inc) $=0$;

congEclusa=lambt.*atendEclusa;

C2S_Eclusa=desvEclusa./atendEclusa;

iaa=isinf(C2S_Eclusa);

$\mathrm{ibb}=\mathrm{isnan}\left(\mathrm{C} 2 \mathrm{~S} \_\right.$Eclusa);

C2S_Eclusa(iaa) $=0$;

C2S_Eclusa(ibb) $=0$;

[desmCanal,tempoDesmemCanal $]=$ desmembra(largCanal,extCanal,atendCanal ... , nCanais);

[desmEclusa,tempoDesmemEclusa]=desmembra(largEclusa,compEclusa, ... atendEclusa, nEclusas);

aaaE $=\left(\right.$ congEclusa.${ }^{*}$ congEclusa $) /(1$-congEclusa $)$;

$\mathrm{iab}=\operatorname{isinf}(\mathrm{aaaE})$;

$\mathrm{ibc}=\mathrm{isnan}(\mathrm{aaaE})$;

$\mathrm{aaaE}(\mathrm{iab})=0$

aaaE(ibc) $=0$

bbbE $=(1+$ C2S_Eclusa $) \cdot / 2$

TEsp_Eclusa $=(1 /$ lambt $) *{ }^{*}$ aaaE.*bbbE;

TSist_Eclusa $=$ atendEclusa + TEsp_Eclusa;

aaaC $=($ congCanal. $*$ congCanal $) /(1$. -congCanal $) ;$

$\operatorname{iad}=\operatorname{isinf}(\operatorname{aaaC})$;

ibe=isnan $(\mathrm{aaaC})$;

$\operatorname{aaaC}(\mathrm{iad})=0$;

aaC $($ ibe $)=0$;

bbbC $=(1+$ C2S_Canal $) . / 2$; 
TEsp_Canal $=(1 /$ lambt $) . * a a a C . * b b b C$;

TSist_Canal $=$ atendCanal + TEsp_Canal;

TEsp_Canal = TEsp_Canal.*(2.*desmCanal-1);

TEsp_Eclusa $=$ TEsp_Eclusa. ${ }^{*}(2 . *$ desmEclusa- 1$)$;

TEspC = sum (TEsp_Canal);

TEspE = sum (TEsp_Eclusa);

TSist_Canal $=$ TSist_Canal.* $(2 . *$ desmCanal-1 $)$;

TSist_Eclusa $=$ TSist_Eclusa.* $(2 . *$ desmEclusa- 1$)$;

TSistC $=$ sum (TSist_Canal);

TSistE = sum (TSist_Eclusa);

TAdn $=2 *\left(\operatorname{sum}\left(\right.\right.$ atendEclusa. ${ }^{*}(2 . *$ desmEclusa -1$\left.)\right)+\operatorname{sum}($ atendCanal. $* .$.

(2.*desmCanal-1)));

TAdp $=2 *($ TEspC + TEspE $)$; 


\section{CUSTOS}

function [Ctotal,Custo_tonelada,fator_merito,Custo_tonelada_km,NVc] $=$ custos $\%$ calcula os custos, trecho a trecho da via, de uma viagem redonda de um comboio $\%$ entradas:

$\%$ dados referentes aos trechos da via global nTrecho nTerminal posTrecho posTerminal calado profundidade ... largura corrente solo nPontes nCurvas nivelVentos nivelOndas ... nivelTroncos nivelNeblina nEclusas nCanais txcarga txdescarga global Lchata Bchata Pchata Tmax nLinhas nColunas nMotor MCR RotNom ... reducao prop_tipo serie diametro AeAo nPas P_D nLemes tipo_Leme ... reducao prop_tipo serie diametro AeAo nPas P_D nLemes tipo_Leme ... area_Leme flancos Lemp Bemp Temp Pemp CB_emp CBchata lemes_proa ... bow_thruster KaDuto tempo_passagem_pontes nChatas_comboio global raioCurva largCurva profCurva corrCurva vaoPonte largPilar ... largPonte profPonte ambientePonte extCanal largCanal profCanal ... atendCanal desvCanal largEclusa compEclusa calEclusa ... atendEclusa desvEclusa cal i_forma eficProp Ntrip IDV lambt... Salario_medio rancho_dia NDM CuOD espera_carga Vt Dt global Wt ht Vct PAC Cterminais custo_t_term deslocamento Vreal PBt $\%$ global Ctotal Custo_tonelada fator_merito Custo_tonelada_km $\%$ $\%$ caracterizaçao da via

$\%$ Dt - distancia entre dois pontos extremos de em trecho $(\mathrm{km})$

$\%$ largura - largura media do trecho (m)

$\%$ profundidade - profundidade media do trecho $(\mathrm{m})$

$\%$ corrente - velocidade de corrente media do trecho $(\mathrm{m} / \mathrm{s})$

$\%$ atendEclusa - tempo medio de atendimento em cada operaçao de eclusagem

$\%$ ou de passagem por canal estreito: vetor Umi(pt) (hora)

$\%$ desvEclusa - desvio padrao do tempo de atendimento Umi (hora)

$\%$ lambt - fluxo medio de chegada de embarcaçoes em eclusas/canais $\%$ nos dois sentidos (comboios/hora)

$\%$ IDV - indice de disponibilidade do trecho da via (de 0 a 1 )

$\%$ caracterizaçao do comboio

$\%$ Lchata - comprimento de uma chata $(\mathrm{m})$

$\%$ Bchata - boca de uma chata (m)

$\%$ Tchata - calado das chatas no trecho em questao (m)

$\%$ Pchata - pontal das chatas (m) 
$\%$ CBchata - coeficiente de bloco de uma chata (m)

$\%$ nLinhas - numero de linhas na formaçao do comboio

$\%$ nColumas - numero de colunas na formaçao do comboio

$\%$ Vreal - \% velocidade do comboio no trecho $(\mathrm{m} / \mathrm{s})$

$\%$ eficProp - eficiencia propulsiva

$\%$ nMotor - numero de propulsores/motores no empurrador

$\%$ MCR - potencia instalada de um motor do empurrador $(\mathrm{kW})$

$\%$ dados operacionais

$\%$ turno - numero de horas uteis diarias em que o comboio opera

$\%$ Ntrip - numero de tripulantes do comboio

$\%$ txcarga - taxa de carregamento em terminal $(\mathrm{t} / \mathrm{h})$

$\%$ txdescarga - taxa de descarregamento em terninal $(\mathrm{t} / \mathrm{h})$

$\%$ espera_carga - fraçao do tempo de carga/descarga em que realmente

$\% \quad$ o empurrador espera (pode haver chatas ja prontas)

$\%$ NDM - numero de dias em manutençao anual do comboio

$\%$

\% VALORES ASSUMIDOS PELO PROGRAMA (podem ser atualizados / revistos):

$\mathrm{Kc}=0.12 ; \quad \%$ coeficiente de peso em aço $=0,12 \mathrm{t} / \mathrm{m} 3$

preco_aco_chata $=6400$; $\%$ para chatas: $\mathrm{R} \$ 6.400,00 /$ tonelada de aço processado preco_aco_emp $=7400$; $\%$ para empurrador:R $\$ 7.400,00 /$ tonelada de aço processado

if RotNom $<=1500$

cte_maq $=3400 ; \%$ custo de maquinas para motores ate $1500 \mathrm{rpm}$

else

cte_maq $=2200 ; \%$ custo de maquinas para motores com rotaçoes $>1500 \mathrm{rpm}$

end

Cmanut $=0.04 ; \%$ custo de docagens e manutençao $=4 \%$ do preço comboio

if prop_tipo $>2$

cte_maq=cte_maq $* 1.5$;

Cmanut $=$ Cmanut $* 1.5$

end

if tipo_Leme $==2$

cte_maq=cte_maq*1.2;

Cmanut $=$ Cmanut $* 1.05$;

end

juros $=0.12 ; \%$ taxa de juros anuais $=12 \%$

$\mathrm{n}=20 ; \quad \%$ periodo de retorno do capital $=20$ anos 
$\mathrm{VRc}=0.20 ; \%$ valor residual das chatas ao final de 20 anos $=20 \%$

$\% \quad$ do preco do empurrador

VRemp $=0.20 ; \%$ valor residual do empurrador ao final de 20 anos $=20 \%$

$\% \quad$ do preco do empurrador

fracao_adm $=0.10 ; \%$ custo de administraçao $(\%$ dos demais custos $)=10 \%$

fracao_seg $=0.05 ; \%$ fraçao do custo de capital (anual) $=5 \%$

Cespod $=0.285 ; \%$ consumo especifico medio de oleo Diesel $=0,285$ litro $/ \mathrm{kW} / \mathrm{h}$

Rol $=0.005 ; \%$ relaçao entre custos de consumos de oleo lubrificante

$\% \quad$ e de oleo Diesel

Fcons $=0.003 ; \%$ custo de consumiveis diversos $=0,3 \%$ do custo de oleo Diesel

Fgerador $=0.08 ; \%$ consumo de oleo pelos geradores $=8 \%$ do consumo dos

$\% \quad$ motores principais

horas_term $=24 . ; \%$ numero de horas por dia de funcionamento dos terminais

turno=24.; $\quad \%$ numero de horas de operaçao do comboio por dia

encargos $=110 ; \%$ encargos sociais sobre o salario da tripulaçao $(\mathrm{em} \%)$

Paco_chata $=$ Kc*Lchata*Bchata*Pchata

Paco_emp $=$ Kc*Lemp*Bemp*Pemp;

DWTc $=$ zeros $(1$, nTrecho*2);

TNtrecho=zeros $(1, \mathrm{nTrecho} * 2)$;

potencia $=$ zeros $(1$, nTrecho*2);

peso_leve $=$ nLinhas $*$ nColunas*Paco_chata;

cte_ $\mathrm{x}=$ nLinhas $*$ nColunas $*$ CBchata*Lchata*Bchata;

deslocamento $=$ cte_x.*'cal;

DWTc=deslocamento-peso_leve;

Dist_total=sum(Dt);

TNtrecho=Dt./(3.6 *Vreal);

$\mathrm{TN}=\operatorname{sum}(\mathrm{TN}$ trecho $) ; \%$ tempo navegando em uma viagem em horas

potencia $=\mathrm{PBt} . * \mathrm{Dt} ; \%$ potencia dos motores utilizada no trecho

vel=Vt.*Dt;

Vel_media $=\operatorname{sum}($ vel $) /$ Dist_total $\%$ velocidade media em toda a viagem

Pot_media=sum(potencia)/Dist_total $\%$ potencia media em toda a viagem

$\%$ tempos adicionais navegando e parado (eclusas e canais)

$\%$ [TAdn,TAdp]=eclusas_canais

TAdn $=0$;

TAdp $=0$;

$\%$ tempos em terminais

carga $=$ zeros $(1$, nTerminal $)$;

$\operatorname{cargaX}=$ zeros $(1, \mathrm{nTerminal})$;

dif_carga=zeros $(1$, nTerminal $)$; 
carga $=($ cte_x.*alado $)-$ peso_leve;

$\operatorname{cargaX}=[0$ carga(1:nTerminal-1) $]$;

$\mathrm{km} \_$term $=[0$ posTerminal(1:nTerminal-1)];

dif_km_term $=$ abs(posTerminal-km_term);

dif_carga $=($ carga-cargaX $)$;

espera_term=espera_carga.*dif_carga

iposit=find(dif_carga $>0)$;

inegat=find(dif_carga $<0$ );

carga_total $=$ sum(dif_carga(iposit) $)$

tempo_carga $=$ espera_term(iposit)./txcarga(iposit)

tempo_descarga $=$ abs(espera_term $($ inegat $))$./txdescarga(inegat $)$

$\%$ tempo total em terminais

DurOper $=(\operatorname{sum}($ tempo_carga $)+\operatorname{sum}($ tempo_descarga $)) /$ horas_term; $\%$ em dias

$\%$ carga transportada por quilometro percorrido

Carga_km=sum(cargaX.*dif_km_term);

$\% \quad$ TV $=$ TN + TAdn + TAdp + tempo_passagem_pontes; \% tempo em viagem, em horas

$\mathrm{TV}=\mathrm{TN}$

DurV = TV / turno; \% duraçao de uma viagem sem tempo em terminais (dias)

$\mathrm{TC}=\mathrm{DurV}+$ DurOper \% tempo de ciclo de uma viagem (dias)

$\mathrm{NDI}=365 *(1-\mathrm{IDV} / 100)+\mathrm{NDM} ; \%$ numero de dias inativos no ano (dias)

$\mathrm{NVc}=(365-\mathrm{NDI}) / \mathrm{TC} \%$ numero de viagens anual do comboio

carga_viagem $=$ Carga_km/Dist_total; $\%$ carga media transportada por viagem

$\mathrm{PAC}=\mathrm{NVc} *$ carga_total $; \%$ produçao anual do comboio PAC

PAC_km $=$ NVc*arga_viagem; $\%$ produçao anual do comboio ponderada por km

$\%$

\section{$\%$ CUSTOS UNITARIOS (em REAIS)}

$\%$

Preco_chatas $=$ preco_aco_chata*Paco_chata*nChatas_comboio

Preco_empurrador $=$ preco_aco_emp*Paco_emp+cte_maq*MCR*nMotor

$\%$ preco atualizado das chatas e empurrador

Pratual $=$ Preco_chatas + Preco_empurrador $-1 /(1+\text { juros })^{\wedge} n^{*}\left(\mathrm{VRc}^{*} \ldots\right.$

Preco_chatas+VRemp*Preco_empurrador)

Ccapital $=$ Pratual $*$ juros $*(1+\text { juros })^{\wedge} \mathrm{n} /\left((1+\text { juros })^{\wedge} \mathrm{n}-1\right) \%$ custo de capital

$\%$ custo de salarios, considerando acrescimo de tripulantes para revezamentos

Csalario $=12 *($ Ntrip+floor $(($ Ntrip-1) $/ 2)) *$ Salario_medio $*(1+$ encargos $/ 100)$

Crancho $=365 *$ Ntrip $*$ rancho_dia $\%$ custo de alimentaçao da tripulaçao

Cdocagem $=$ Cmanut $*$ Pratual $\%$ custo de docagens $=$ uma fraçao do preço atual

Cseguro=fracao_seg*Pratual \% custo de seguros= uma fraçao do preço atual 
Cadm $=$ fracao_adm* $*$ Ccapital+Csalario+Crancho+Cdocagem+Cseguro $)$

$\%$ custo de administraçao $=$ porcentagem dos demais custos

$\%$ Custo parado (custo por hora)

Cparado $=($ Ccapital + Csalario + Crancho + Cdocagem + Cseguro + Cadm $) / 8760$

C_O_D $=(1+$ Fgerador $) *$ CuOD*Pot_media*Cespod*nMotor; $\%$ consumo de oleo Diesel

$\%$ o fator Fgerador acrescenta o oleo consumido pelos geradores

C_O_L $=$ Rol*C_O_D; \% consumo de oleo lubrificante, porcentagem de C_O_D

Ccons $=$ Fcons $*$ C_O_D $\%$ custo de outros consumiveis, porcentagem de C_O_D

Cnavegando $=$ Cparado + C_O_D + C_O_L + Ccons $\%$ custo navegando por hora

$\%$ CUSTO TOTAL

$\mathrm{TNT}=\mathrm{NVc} *(\mathrm{TN}+\mathrm{TAdn}) \%$ tempo total navegando $(\mathrm{em}$ horas $)$

TPT $=8760$ - TNT \% tempo parado (em horas)

Cterminais=custo_t_term*PAC*2 \% custo de movimentaçao de cargas nos terminais

Ctotal $=$ Cnavegando $*$ TNT + Cparado $*$ TPT + Cterminais $\%$ custo total (Reais)

Custo_tonelada $=$ Ctotal $/ \mathrm{PAC} ; \%$ custo por tonelada transportada $(\mathrm{R} \$ / \mathrm{t})$

Custo_tonelada_km=Custo_tonelada/Dist_total $* 2 ; \%$ custo por tonelada quilometro

$\%$ fator de merito de transporte

fator_merito $=$ carga_total $*$ Vel_media $/$ Pot_media 


\section{HOWE}

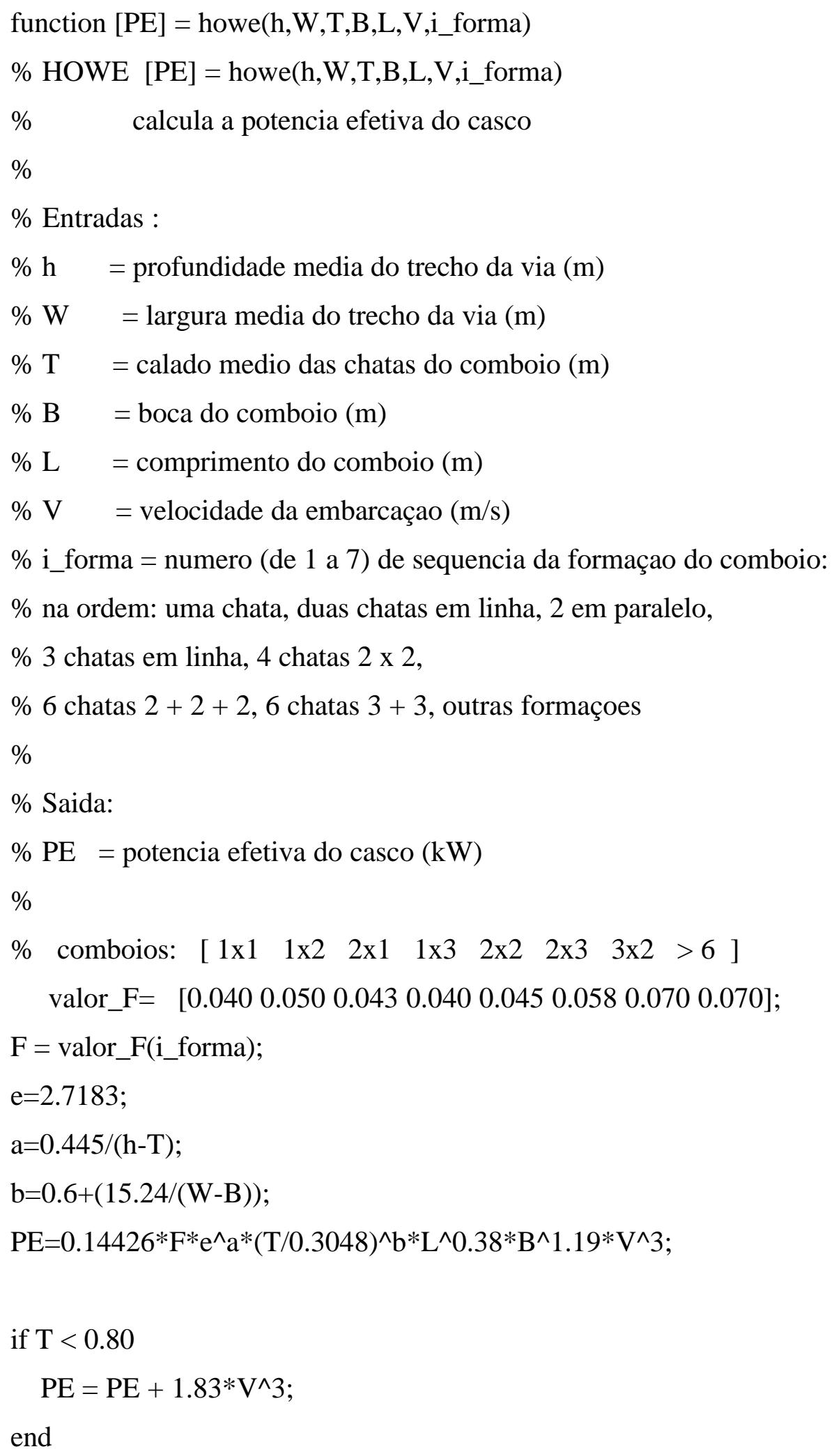




\section{PONTES}

function [PG,lin,col,num_passagens,tempo_passagem $]=$ pontes $($... vaoPonte,largPilar,i_ponte)

$\%$ Funçao de verificaçao da necessidade de desmembramentos em pontes

$\%$ e de estimativa de probabilidade geometrica de colisao do comboio

$\%$ com um dos pilares

$\%$

\% Carlos Daher Padovezi - 2003

$\%$

global Lchata Bchata nLinhas nColunas Lemp desmPonte VelCor_x ...

VelCor_y DesmCanal tetaPonte risco_ponte

$\%$ Entradas:

$\%$ Lchata - comprimento de uma chata (m)

$\%$ Bchata - boca de uma chata (m)

$\%$ Lemp - comprimento do empurrador (m)

$\%$ nLinhas - numero de linhas de chatas da formaçao do comboio

$\%$ nColunas - numero de colunas de chatas da formaçao do comboio

$\%$ vaoPonte - vao horizontal da ponte - no canal de navegaçao (m)

$\%$ largPilar - largura dos pilares da ponte (m)

$\%$

\% Saidas:

$\%$ num_passagens - numero de passagens (com ou sem desmembramentos) sob a ponte

$\%$ tempo_passagem - tempo total de passagem(ns) (hora)

$\%$ lin - numero de linhas do comboio que passa sob a ponte

$\%$ col - numero de colunas do comboio que passa sob a ponte

$\%$ PG - probabilidade geometrica de colisao do comboio com a ponte

$\%$

\% Utilizaçao da probabilidade geometrica (PG) - AASHTO (1991)

passa $=0$;

lin = nLinhas;

col = nColunas; 


$$
\begin{aligned}
& \text { while passa }==0 \\
& \text { boca }=\text { lin } * \text { Bchata; } \\
& \text { LOA = vaoPonte; } \\
& \% \mathrm{LOA}=\mathrm{col} * \text { Lchata }+ \text { Lemp; \% comprimento total do comboio (m) } \\
& \% \quad \text { sigma }=\mathrm{LOA} ; \% \text { desvio da distribuiçao normal - criterio AASHTO } \\
& \mathrm{x} 1=(\text { vaoPonte } / 2 \text { - boca }) / L O A ; \\
& \mathrm{x} 2=(\text { vaoPonte } / 2+\operatorname{largPilar}+\text { boca }) / \mathrm{LOA} ; \\
& \mathrm{x}=\left[\begin{array}{ll}
\mathrm{x} 1 & \mathrm{x} 2
\end{array}\right] \text {; } \\
& \mathrm{PG}=\text { normspec }(\mathrm{x}, 0,1) \text {; } \\
& \text { if } \mathrm{PG}<=0.260
\end{aligned}
$$

$\%$ assumido que $\mathrm{PG}<=0,260$ eh aceitavel para passagem sob pontes

$$
\text { passa }=1 ;
$$

else

$$
\begin{aligned}
& \text { if } \operatorname{lin}==1 \& \text { col }==1 \\
& \text { passa }=1 ; \\
& \text { end }
\end{aligned}
$$$$
\text { if lin }>1
$$$$
\operatorname{lin}=\operatorname{lin}-1 \text {; }
$$$$
\text { boca }=\text { lin * Bchata; }
$$$$
\text { elseif col > } 1
$$

$$
\mathrm{col}=\mathrm{col}-1 \text {; }
$$$$
\text { LOA }=\text { col } * \text { Lchata }+ \text { Lemp; }
$$

end

end

end

num_passagens $=\operatorname{ceil}(($ nColunas $*$ nLinhas $) /($ lin $*$ col $))$;

tempo_1_passagem $=0.7$;

if num_passagens $==1$

$$
\text { tempo_1_passagem }=0.20 \text {; }
$$

end

$\%$ assumido tempo_1_passagem $=0,70$ hora (tempo de desmembramentos +1 passagem 
tempo_passagem $=2 *(2 *$ num_passagens -1$) *$ tempo_1_passagem; $\%$ ida e volta close all;

$\%$ probabilidade $\mathrm{PA}$

$$
\begin{aligned}
& \mathrm{rb}=1+\text { abs(tetaPonte(i_ponte)/90); } \\
& \text { rc }=1+\operatorname{abs}(\text { VelCor_x(i_ponte)/5.144); } \\
& \text { rcx }=1+\text { abs(VelCor_y(i_ponte)/0.5144); } \\
& \mathrm{rd}=1 \text {; } \\
& \mathrm{PA}\left(\mathrm{i} \_ \text {ponte }\right)=0.00012 * \mathrm{rb} * \mathrm{rc} * \mathrm{rcx} * \mathrm{rd} \text {; } \\
& \text { sss }=\mathrm{PG} \\
& \text { aaa }=2 * \text { num } \_ \text {passagens }-1 \\
& \text { risco_ponte }(\text { i_ponte })=\mathrm{PA}(\text { i_ponte }) * \mathrm{PG} \text {; }
\end{aligned}
$$




\section{VENTOS}

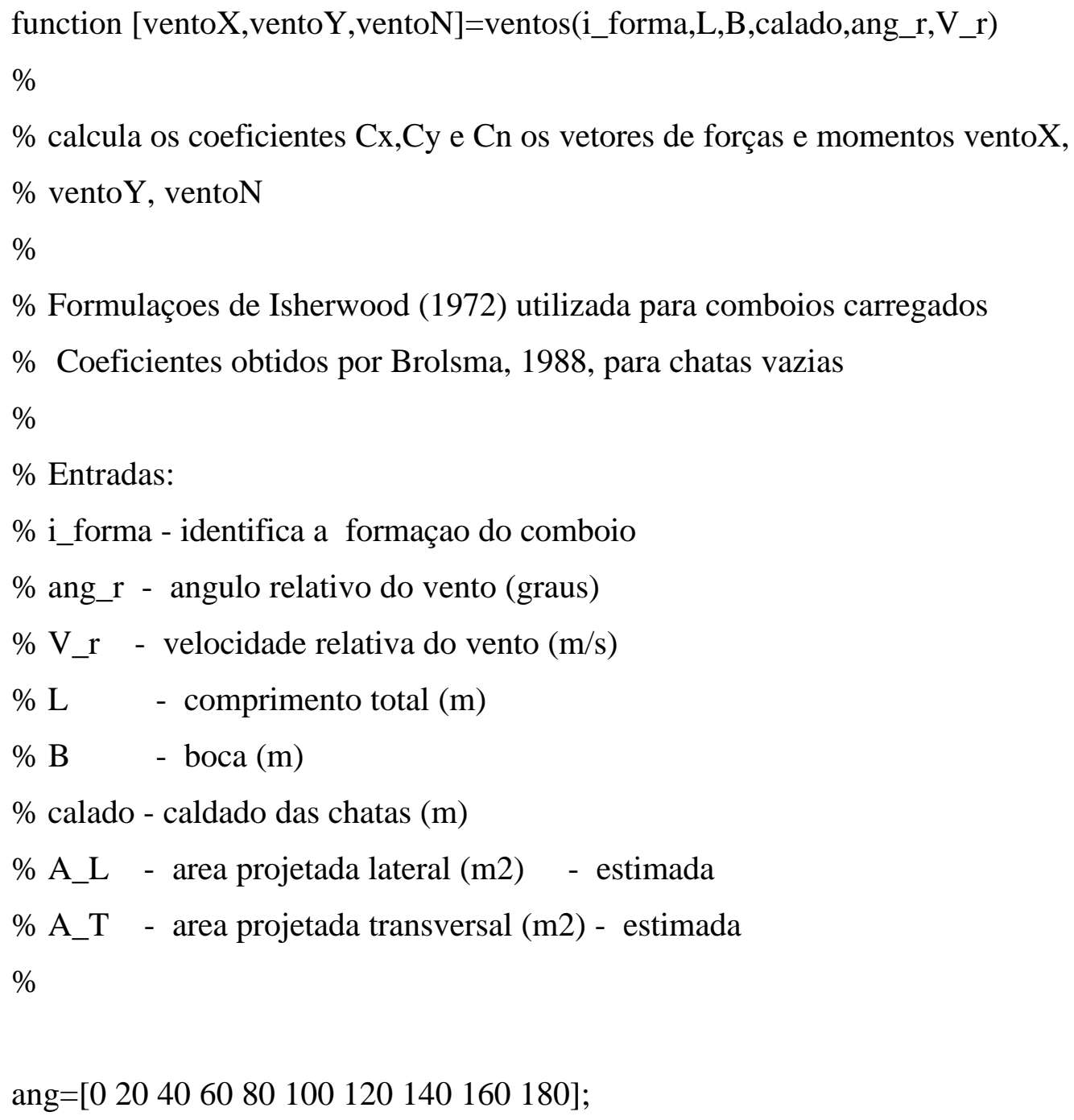


VI_5 $=0.568$;

VI_6 $=0.211$;

$\%$ CX_data $=\left[\begin{array}{lllllll}\operatorname{ang} \_r & \text { A0 } & \text { A1 } & \text { A2 } & \text { A3 } & \text { A4 } & \text { A5 }\end{array}\right]$

CX_data $=[\ldots$

\begin{tabular}{|c|c|c|c|c|c|c|c|}
\hline 0 & 2.152 & -5.00 & 0.243 & -0.164 & & 0 & \\
\hline 10 & 1.714 & -3.33 & 0.145 & -0.121 & & 0 & \\
\hline 20 & 1.818 & -3.97 & 0.211 & -0.143 & & 0 & \\
\hline 30 & 1.965 & -4.81 & 0.243 & -0.154 & & 0 & \\
\hline 40 & 2.333 & -5.99 & 0.247 & -0.190 & & 0 & \\
\hline 50 & 1.726 & -6.54 & 0.189 & -0.173 & 0.348 & 0 & \\
\hline 60 & 0.913 & -4.68 & 0 & -0.10 & & 0.482 & 0 \\
\hline 70 & 0.457 & -2.88 & 0 & -0.06 & & 0.346 & 0 \\
\hline 80 & 0.341 & -0.91 & 0 & -0.03 & & 0 & 0 \\
\hline 90 & 0.355 & 0 & 0 & 0 & -0.247 & 0 & \\
\hline 100 & 0.601 & 0 & 0 & 0 & -0.37 & 72 & 0 \\
\hline 110 & 0.651 & 1.29 & 0 & 0 & -0.58 & 82 & 0 \\
\hline 120 & 0.564 & 2.54 & 0 & 0 & -0.74 & 48 & 0 \\
\hline 130 & -0.142 & 3.58 & 0 & 0.047 & & -0.700 & 0 \\
\hline 140 & -0.677 & 3.64 & 0 & 0.069 & & -0.529 & 0 \\
\hline 150 & -0.723 & 3.14 & 0 & 0.064 & & -0.475 & 0 \\
\hline 160 & -2.148 & 2.56 & 0 & 0.081 & & 0 & 1.27 \\
\hline 170 & -2.707 & 3.97 & -0.175 & 0.126 & 0 & 1.81 & \\
\hline 180 & -2.529 & 3.76 & -0.174 & 0.128 & 0 & 1.55 & ]; \\
\hline
\end{tabular}

\% CY_data $=\left[\begin{array}{lllllll}\text { ang_r B0 } & \text { B1 } & \text { B2 } & \text { B3 } & \text { B4 } & \text { B5 } & \text { B6 }\end{array}\right.$ CY_data $=[\ldots$

$\begin{array}{llllllll}0 & 0 & 0 & 0 & 0 & 0 & 0 & 0\end{array}$

$\begin{array}{lllllllllll}10 & 0.096 & 0.22 & 0 & 0 & 0 & 0 & 0 & & \\ 20 & 0.176 & 0.71 & 0 & 0 & 0 & 0 & 0 & \\ 30 & 0.225 & 1.38 & 0 & 0.023 & 0 & & -0.29 & 0 \\ 40 & 0.329 & 1.82 & 0 & 0.043 & 0 & -0.59 & 0 & & \\ 50 & 1.164 & 1.26 & 0.121 & 0 & & -0.242 & -0.95 & 0 & \end{array}$




$\begin{array}{llllllllllll}60 & 1.163 & 0.96 & 0.101 & 0 & & -0.177 & -0.88 & 0 & \\ 70 & 0.916 & 0.53 & 0.069 & 0 & 0 & -0.65 & 0 & & \\ 80 & 0.844 & 0.55 & 0.082 & 0 & 0 & -0.54 & 0 & & \\ 90 & 0.889 & 0 & 0.138 & 0 & 0 & -0.66 & 0 & \\ 100 & 0.799 & 0 & 0.155 & 0 & 0 & -0.55 & 0 & \\ 110 & 0.797 & 0 & 0.151 & 0 & 0 & -0.55 & 0 \\ 120 & 0.996 & 0 & 0.184 & 0 & -0.212 & -0.66 & 0.34 \\ 130 & 1.014 & 0 & 0.191 & 0 & -0.280 & -0.69 & 0.44 \\ 140 & 0.784 & 0 & 0.166 & 0 & -0.209 & -0.53 & 0.38 \\ 150 & 0.536 & 0 & 0.176 & -0.029-0.163 & 0 & 0.27 & \\ 160 & 0.251 & 0 & 0.106 & -0.022 & 0 & 0 & 0 & \\ 170 & 0.125 & 0 & 0.046 & -0.012 & 0 & 0 & 0 & \end{array}$

$\begin{array}{llllllll}1800 & 0 & 0 & 0 & 0 & 0 & 0 & \text { ]; }\end{array}$

$\%$ CN_data $=\left[\begin{array}{llllll}\text { ang_r C0 } & \mathrm{C} 1 & \mathrm{C} 2 & \mathrm{C} 3 & \mathrm{C} 4 & \mathrm{C} 5\end{array}\right]$

CN_data $=[\ldots$

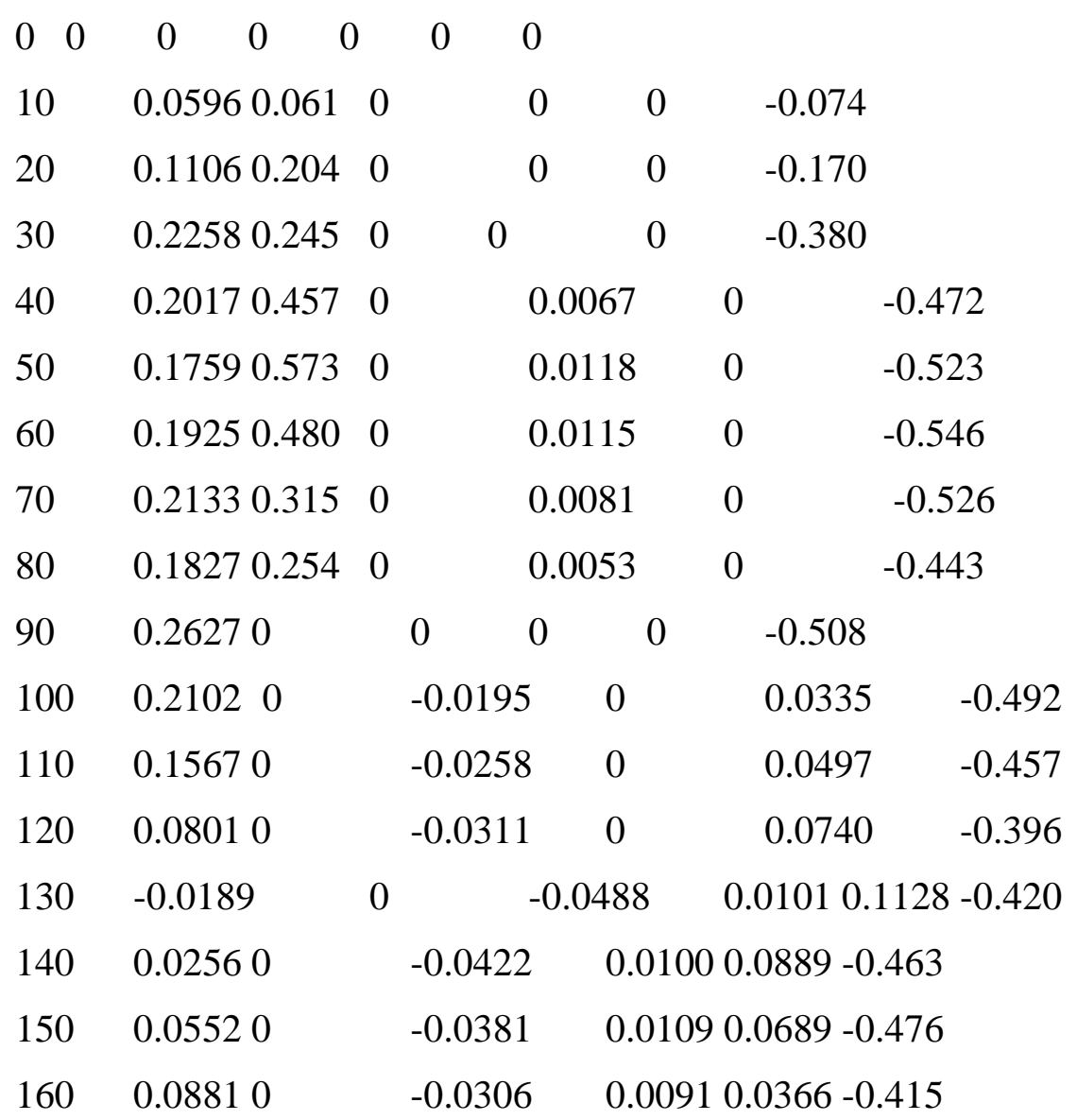




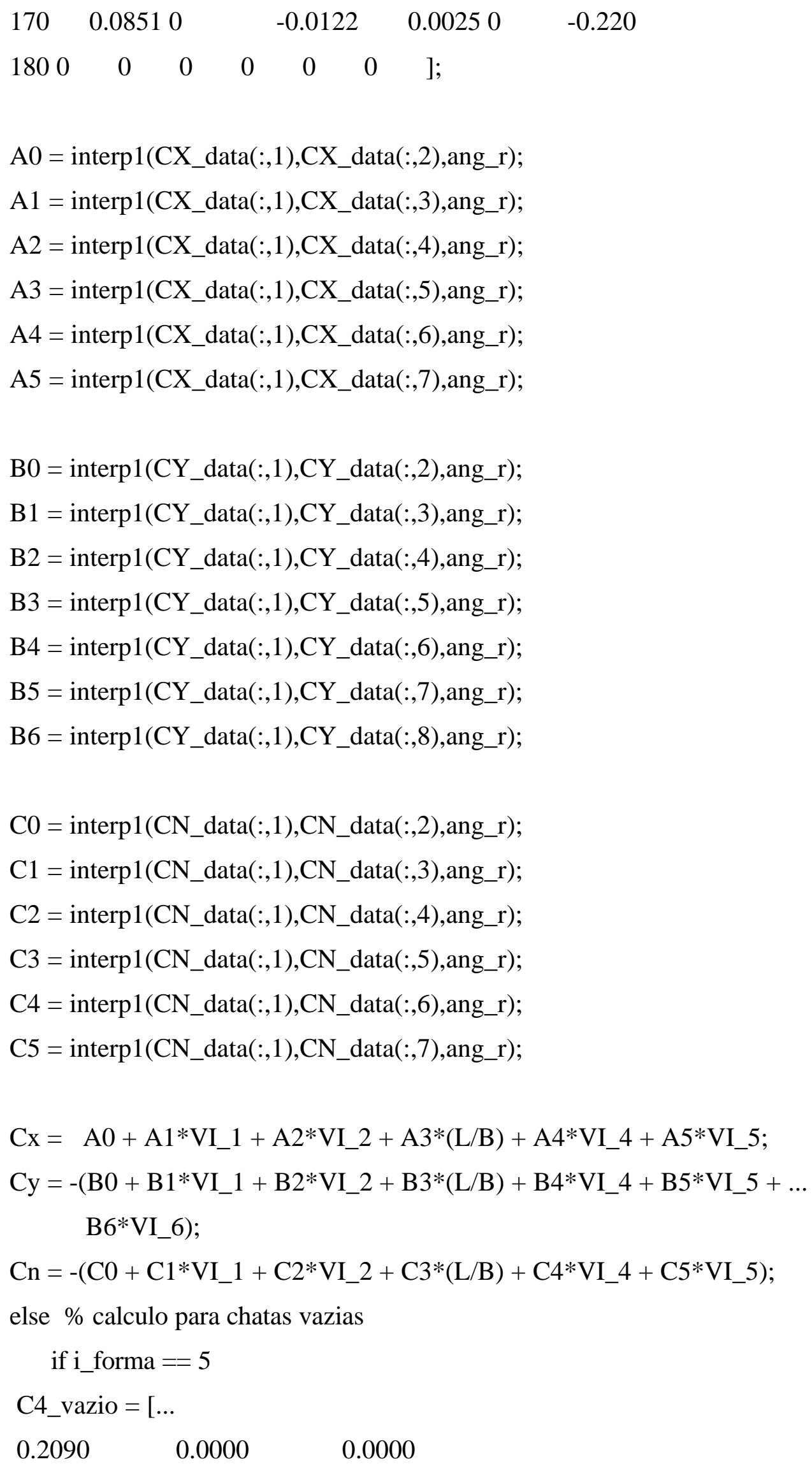




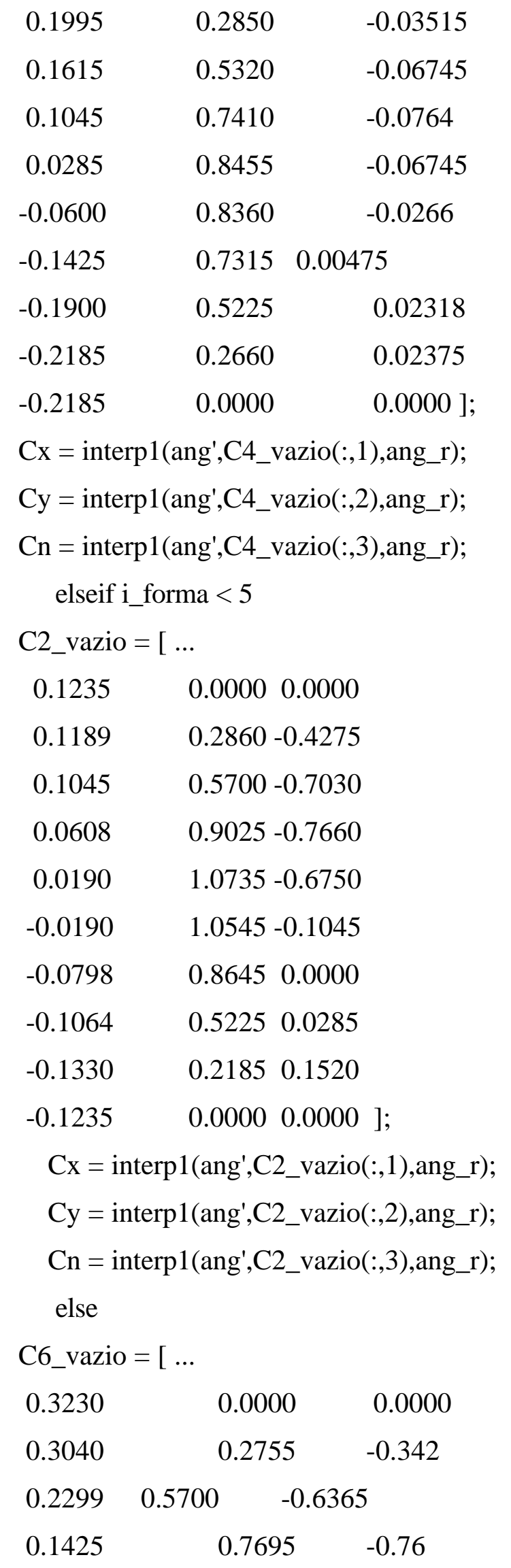




\begin{tabular}{|c|c|c|}
\hline 0.0475 & \multicolumn{2}{|c|}{$0.8455-0.6555$} \\
\hline-0.0570 & 0.8360 & -0.2565 \\
\hline-0.1615 & 0.7505 & 0.1045 \\
\hline-0.2565 & 0.5795 & 0.4465 \\
\hline-0.3135 & 0.3040 & 0.3135 \\
\hline-0.3040 & 0.0000 & $0.0000]$ \\
\hline \multicolumn{3}{|c|}{ Cx = interp1(ang',C6_vazio(:,1),ang_r); } \\
\hline \multicolumn{3}{|c|}{ Cy = interp1(ang',C6_vazio(:,2),ang_r); } \\
\hline \multicolumn{3}{|c|}{$\begin{array}{l}\text { Cn = interp1(ang',C6_vazio(:,3),ang_r }) \text {; } \\
\text { end }\end{array}$} \\
\hline \multicolumn{3}{|l|}{ end } \\
\hline \multicolumn{3}{|c|}{ ventoX $=0.5 * \mathrm{Cx} *$ ro_a $* \mathrm{~V}_{-} \mathrm{r}^{\wedge} 2 *$ A_T } \\
\hline \multicolumn{3}{|c|}{ vento $\mathrm{Y}=0.5 * \mathrm{Cy} *$ ro_a $* \mathrm{~V} \_\mathrm{r}^{\wedge} 2 * \mathrm{~A} \_\mathrm{L} ;$} \\
\hline
\end{tabular}




\section{RASO}

function $[\mathrm{S}, \mathrm{c}, \mathrm{V} \operatorname{cor}]=\mathrm{raso}(\mathrm{B}, \mathrm{T}, \mathrm{h}, \mathrm{W}, \mathrm{V}, \mathrm{i}$ _solo,criterio $)$

$\%$

$\% \%$ retorna os valores de afundamento;

$\%$ S (squat) e de pe-de-piloto c segundo Eryuslu (1994);

$\%$ entradas:

$\% \mathrm{~B}$ = boca da embarcaçao (m)

$\% \mathrm{~T}$ = calado da embarcaçao $(\mathrm{m})$

$\% \mathrm{~h}=$ profundidade do canal $(\mathrm{m})$

$\% \mathrm{~W}=$ largura do canal de navegaçao $(\mathrm{m})$

$\% \mathrm{~V}=$ velocidade da embarcaçao $(\mathrm{m} / \mathrm{s})$

$\%$ i_solo = tipo de solo do rio (lodos, areia, rocha)

$\%$

$\%$ criterio 1

if criterio $==1$

if i_solo $==$ 'lodos'

$\mathrm{Cmin}=0.3$;

elseif i_solo =='areia'

$\mathrm{Cmin}=0.5$;

else

Cmin=1.0;

end

$\%$ criterio 2

else

$\mathrm{Cmin}=0.10 * \mathrm{~T}$;

end

\% entradas: $\mathrm{B}, \mathrm{T}, \mathrm{h}, \mathrm{W}, \mathrm{V}$

$\%$ saidas: afundamento $\mathrm{S}$ e pe-de-piloto c e Vcor (velocidade corrigida para

$\%$

c $>=$ Cmin)

$\%$ 
$c=0.1$;

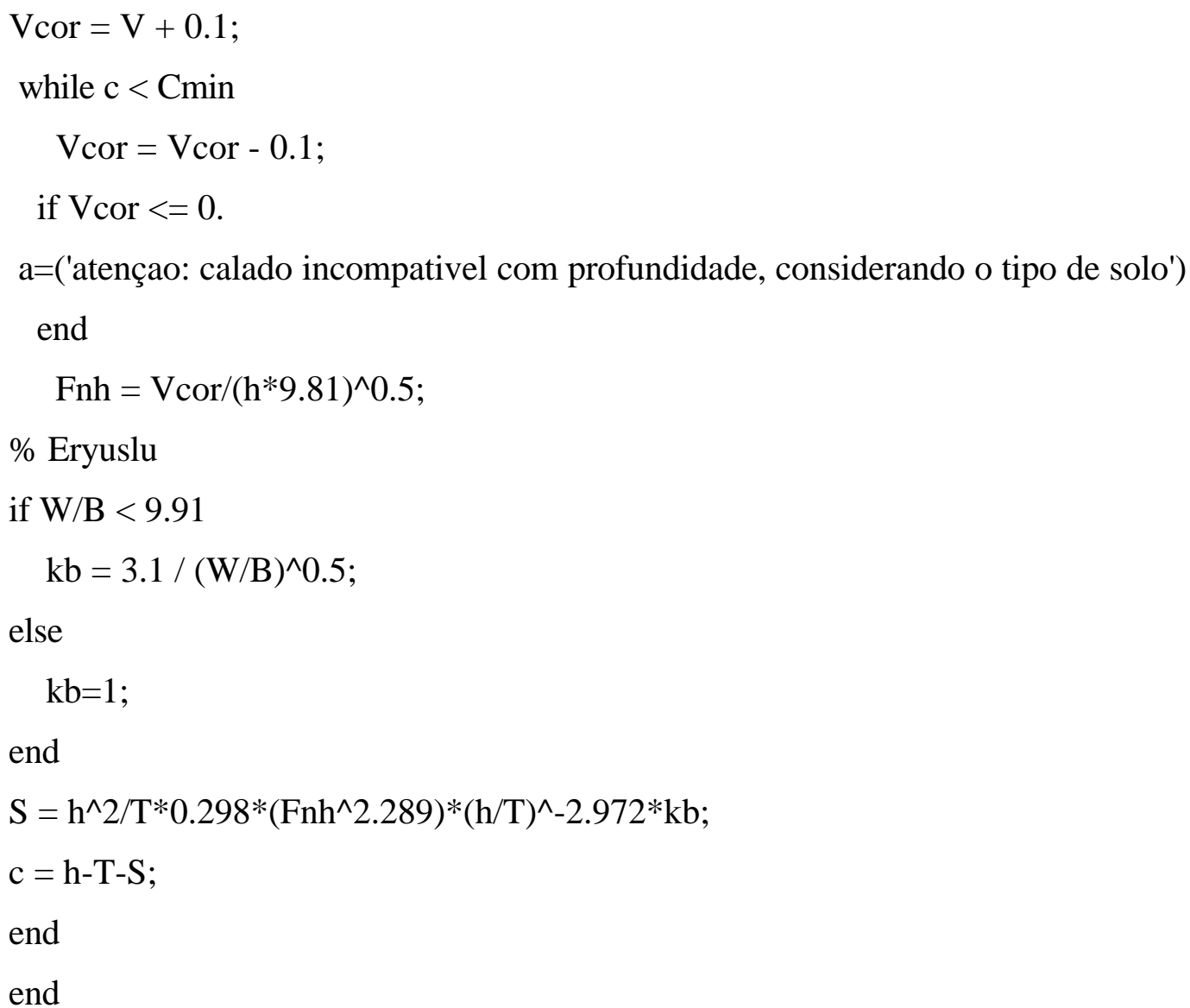

